\title{
The role of brain endothelial surface charge and glycocalyx in the function and integrity of the blood-brain barrier
}

Ph.D. Thesis

\section{Ana Raquel Pato Santa Maria}

Supervisor: Prof. Dr. Mária A. Deli, scientific adviser

Co-supervisor: Dr. Fruzsina R. Walter, research associate

Biological Barriers Research Group, Institute of Biophysics

Biological Research Centre, Szeged

Doctoral School of Biology

Faculty of Science and Informatics

University of Szeged

2020

Szeged 


\section{Table of contents}

List of Publications ..............................................................................................IV

List of Abbreviations .............................................................................................................. VI

1. Introduction ...................................................................................................................... 1

1.1.Blood-brain barrier ............................................................................................... 1

1.2.Negative surface charge of brain endothelial cells: a defense system and a regulator of BBB permeability ...................................................................... 4

1.3.Blood-brain barrier modeling............................................................................. 7

1.3.1. Type of cell models ........................................................................... 8

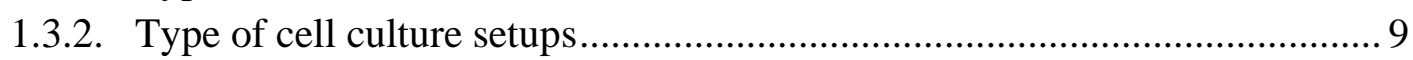

1.4.Techniques to assess blood-brain barrier integrity............................................... 11

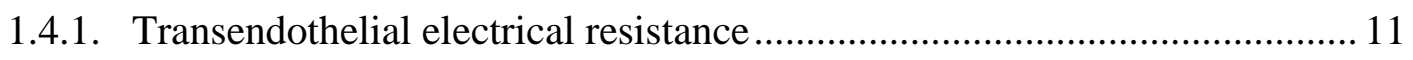

1.4.2. Permeability assay for marker molecules ................................................... 13

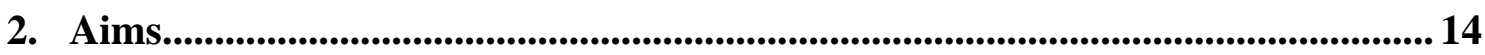

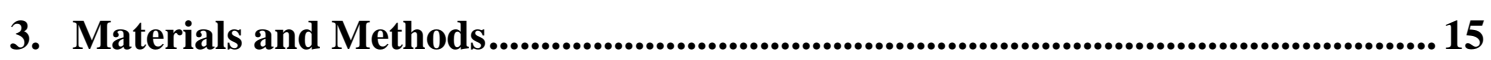

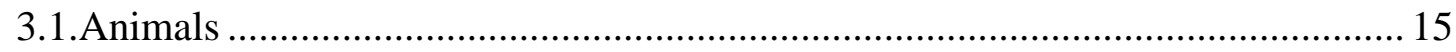

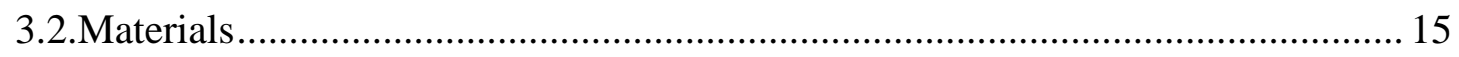

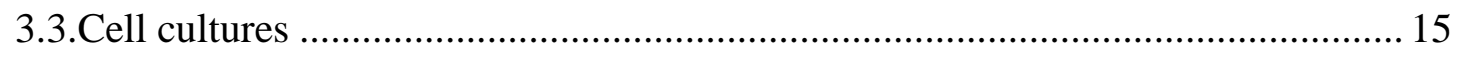

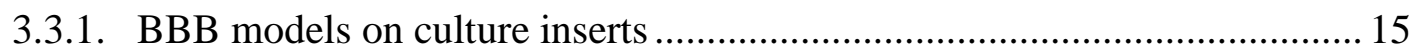

3.3.2. hCMEC/D3 human brain endothelial cell line ........................................... 15

3.3.3. Primary cell cultures and rat BBB co-culture model.................................... 16

3.3.4. Human BBB co-culture model ............................................................... 17

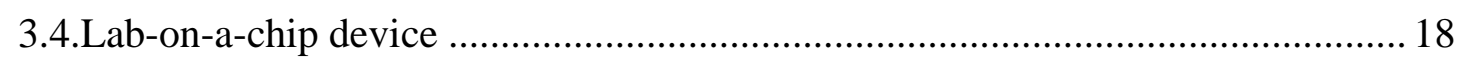

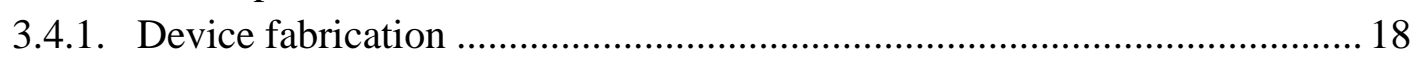

3.4.2. Static and dynamic condition in the chip device ........................................ 19

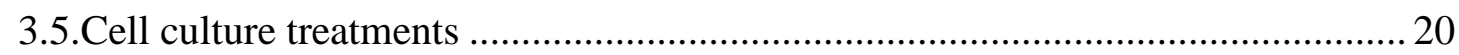

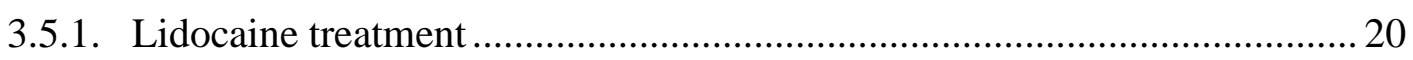

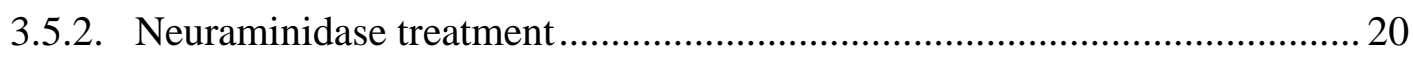

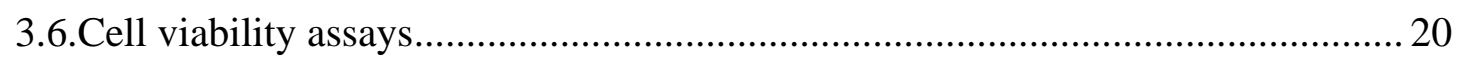

3.6.1. Impedance measurements................................................................... 20

3.6.2. MTT and lactate dehydrogenase release assays ........................................... 21

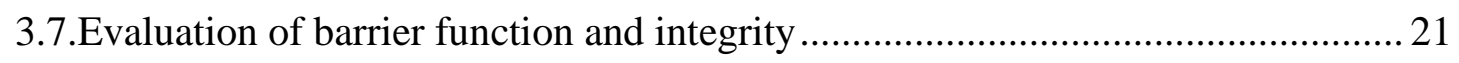

3.7.1. Transendothelial electrical resistance …………….................................... 21

3.7.2. Permeability measurement ........................................................................ 22

3.7.3. Measurement of efflux pump activity ..................................................... 23

3.7.4. Immunocytochemistry for tight junction proteins and image analysis ....... 24

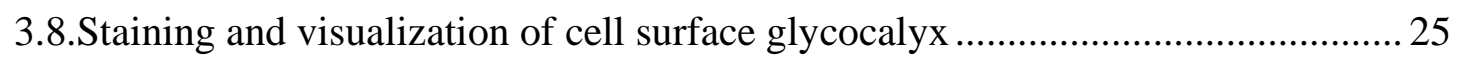

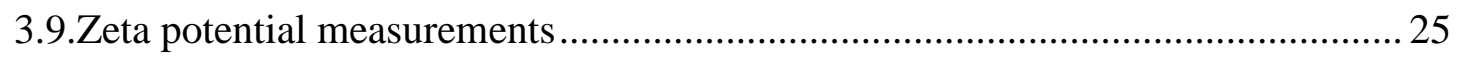

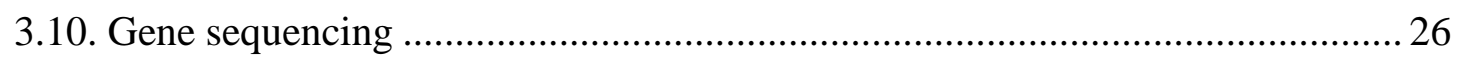

3.10.1. Total RNA isolation ............................................................................. 26

3.10.2. Massive analysis of cDNA ends library preparation and RNA sequencing 26

3.10.3. Bioinformatic analysis of MACE-seq data................................................. 27

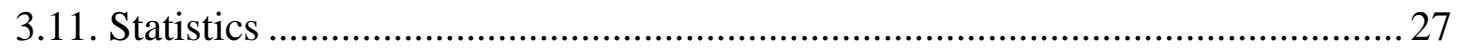


4. Results ................................................................................................................................ 28

4.1.Characterization of the different blood-brain barrier models .............................. 28

4.2.Modulation of the brain endothelial glycocalyx and surface charge using the neuraminidase enzyme

4.2.1. Effect of neuraminidase on the cell viability of primary brain endothelial cells

4.2.2. Neuraminidase as a modulator of the glycocalyx and surface charge of brain

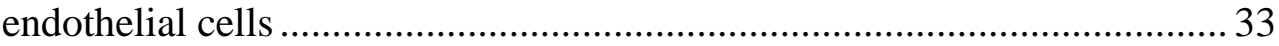

4.2.3. Integrity of the BBB models after neuraminidase treatment ....................... 35

4.3.Modulation of the brain endothelial surface charge by lidocaine ......................... 36

4.3.1. Effect of lidocaine on brain endothelial cell viability ................................ 36

4.3.2. Lidocaine as a modulator of the surface charge of brain endothelial cells . 38

4.3.3. Integrity of the BBB models after lidocaine treatment .............................. 38

4.4.Characterization of a human BBB model in a lab-on-a-chip device .................... 42

4.4.1. Effect of flow on barrier properties of the human BBB model .................. 42

4.4.2. Effect of flow on the global gene expression profile ................................ 44

4.4.3. Effect of flow on endothelial cell markers ................................................. 45

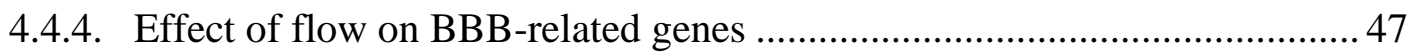

4.4.5. The effect of fluid flow on the endothelial surface charge and glycocalyx of the human BBB model cultured in the lab-on-a-chip device ...................... 51

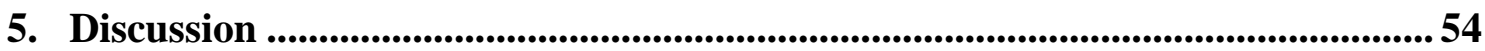

5.1.BBB models in cell culture inserts and lab-on-a-chip device .............................. 54

5.2.Modulation of the brain endothelial surface charge by neuraminidase and lidocaine

5.3.Fluid flow makes brain endothelial surface charge more negative and promotes glycocalyx expression on the human BBB model in the lab-on-a-chip device .... 60

6. Conclusion 65

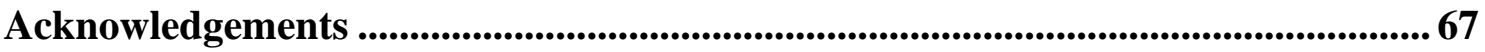

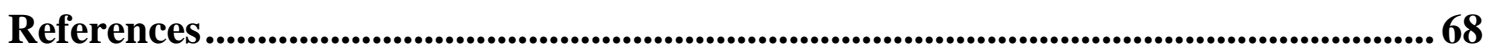

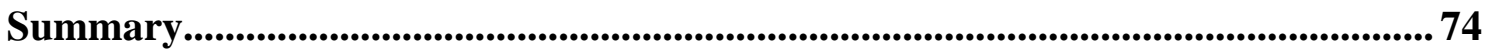

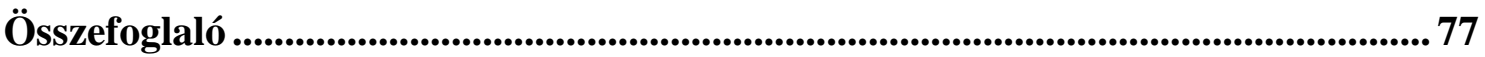

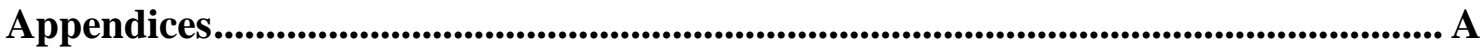

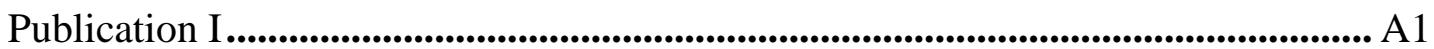

Publication II................................................................................................................ A2

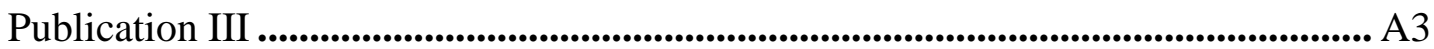

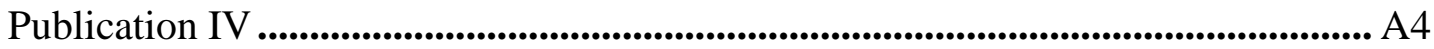




\section{List of Publications}

MTMT identification number: 10055709

Cumulative Impact Factor: 19.21

*Authors contributed equally to the publication

Publication related to the dissertation:

I. Santa-Maria AR, Walter FR, Valkai S, Brás AR, Mészáros M, Kincses A, Klepe A, Gaspar D, Castanho MARB, Zimányi L, Dér A, Deli MA.

Lidocaine turns the surface charge of biological membranes more positive and changes the permeability of blood-brain barrier culture models.

Biochimica et Biophysica Acta - Biomembranes 1861: 1579-1591. (2019)

IF: 3.411

II. Kincses A, Santa-Maria AR, Walter FR, Dér L, Horányi N, Lipka DV, Valkai S, Deli MA, Dér A.

A chip device to determine surface charge properties of confluent cell monolayers by measuring streaming potential.

Lab on a Chip 20: 3792-3805. (2020)

IF: 6.774

III. Santa-Maria AR*, Heymans M*, Walter FR, Culot M, Gosselet F, Deli MA, Neuhaus W.

Transport Studies Using Blood-Brain Barrier in Vitro Models: A Critical Review and Guidelines.

Handbook of Experimental Pharmacology, doi:10.1007/164_2020_394 (2020)

IF: -

IV. Santa-Maria AR, Walter FR, Figueiredo R, Kincses A, Vigh J, Heymans M, Culot M, Winter P, Gosselet F, Dér A, Deli MA

Flow induces glycocalyx-related genes and negative surface charge in a labon-a-chip human blood-brain barrier model.

Manuscript in preparation

Other publications not related to the dissertation:

I. Gróf I, Bocsik A, Harazin A, Santa-Maria AR, Vizsnyiczai G, Barna L, Kiss L, Für G, Rakonczay Jr Z, Ambrus R, Szabó-Révész P, Gosselet F, Jaikumpun P, Szabó H, Zsembery Á, Deli MA.

The Effect of Sodium Bicarbonate, a Beneficial Adjuvant Molecule in Cystic Fibrosis, on Bronchial Epithelial Cells Expressing a Wild-Type or Mutant CFTR Channel.

International Journal of Molecular Sciences 21: 4024. (2020)

IF: 4.556 
II. Francisco DMF, Marchetti L, Rodríguez-Lorenzo S, Frías-Anaya E, Figueiredo RM, BtRAIN Network, Winter P, Romero IA, de Vries HE, Engelhardt B, Bruggmann R.

Advancing brain barriers RNA sequencing: guidelines from experimental design to publication.

Fluids and Barriers of the CNS 17:51. (2020)

IF: 4.470

III. Kanyó N, Kovács K, Saftics A, Székács I, Péter B, Santa-Maria AR, Walter FR, Dér A, Deli MA, Horváth R.

Glycocalyx regulates the strength and kinetics of cancer cell adhesion: biophysical models based on high resolution label-free optical data.

Scientific Reports, under revision

IF: 3.998

IV. Walter FR, Santa-Maria AR, Mészáros M, Veszelka S, Dér A, Deli MA Surface charge, glycocalyx and blood-brain barrier function (review)

Tissue Barriers, Manuscript in preparation

IF: - 


\section{List of Abbreviations}

$\mathrm{AB} \quad$ Luminal compartment to abluminal compartment

ABC ATP-binding cassette

AC Alternating current

AJ Adherens junctions

BA Abluminal compartment to luminal compartment

BBB Blood-brain barrier

BCRP Breast cancer resistance protein

BI Binary images

BLEC Brain-like endothelial cells

BSA Bovine serum albumin

CNS Central nervous system

CS Chondroitin sulfate

DC Direct current

DW Distilled water

EBA Evans-blue labeled albumin

EC Endothelial cells

ESG Endothelial surface glycocalyx

EVOM Epithelial Voltohmmeter

FBS Fetal bovine serum

FD Fluorescein isothiocyanate (FITC)-dextran

GAG Glycosaminoglycan

GEO Gene expression omnibus

HA Hyaluronic acid

hCMEC/D3 Human brain endothelial cell line

hEC Human endothelial cells

hiPSC Human induced pluripotent stem cells

HS Heparan sulfate

I Ion current

ITS Insulin-transferrin-sodium selenite

LDH Lactate dehydrogenase

LOC Lab-on-a-chip 
LY Lucifer yellow

MDR Multidrug resistance proteins

MRPs multidrug resistance associated proteins

MTT (3-(4,5-dimethylthiazol2-yl)-2,5-diphenyltetrazolium bromide

NVU Neurovascular unit

OATPs Organic acid transporting polypeptides

$\mathrm{P}_{\text {app }}$

Apparent permeability coefficient

PBS Phosphate buffered saline

PC Pericytes

PCR Polymerase chain reaction

$\mathrm{P}_{\mathrm{e}} \quad$ Endothelial permeability coefficient

Pgp P-glycoprotein

R123 Rhodamine-123

RBEC Rat brain endothelial cells

SLC Solute carriers

TEER Transendothelial electrical resistance

TJ Tight junctions

U Voltage

WGA Wheat germ agglutinin 


\section{Introduction}

\subsection{Blood-brain barrier}

Blood vessels of the human brain provide brain cells with oxygen, metabolites and nutrients, and ensure the removal of carbon dioxide and other metabolic by products (Sweeney et al., 2019). The dynamic interface created by the blood vessels separates the central nervous system (CNS) from the periphery (Abbott et al., 2010). Capillaries are the smallest blood vessels, which form the basis of the blood-brain barrier (BBB) (Sweeney et al., 2019). They are composed of endothelial cells (ECs) that exhibit special features which make them different from other endothelial cells in peripheral organs (Abbott et al., 2010; Campos-Bedolla et al., 2014). The unique BBB characteristics are induced during development (Obermeier et al., 2013) and are maintained by the close and dynamic interaction between the brain endothelial cells and the other cells creating the neurovascular unit (NVU) (Figure 1).

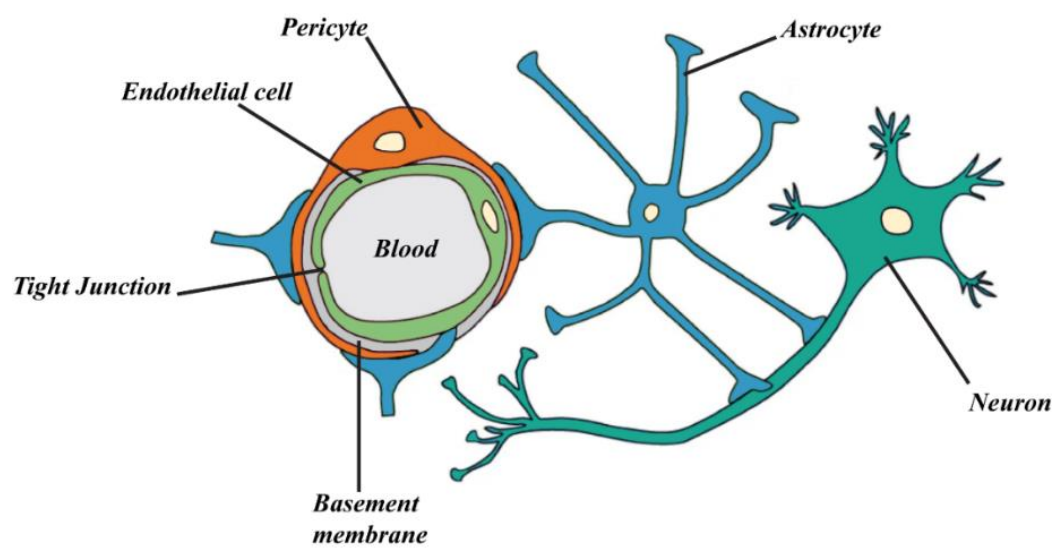

Figure 1. The neurovascular unit. Brain endothelial cells share the basement membrane with pericytes and communicate with the astrocyte end-feet. Perivascular neurons communicate with each other and with the other cell types (Image credit: Gergő Porkoláb, adapted from Sweeney, et al., 2016).

These interactions within NVU involve the communication of the ECs, sharing the same basement membrane with pericytes (PC) with the surrounding astrocyte endfeet, and simultaneously keeping communication with neighboring neurons and microglia (Obermeier et al., 2013; Bell et al., 2020). Pericytes have been shown to have an important role in the formation of the $\mathrm{BBB}$ during development and maintaining its function during adulthood and aging, while astrocytes are crucial mediators of the function and formation of the BBB (Daneman and Prat, 2015). The basement membrane 
of brain capillaries is formed by extracellular matrix components secreted by both ECs and PCs, such as collagen type IV, laminin, heparan sulfate proteoglycans, and other glycoproteins (Daneman and Prat, 2015). This basement membrane is an anchor for several signaling pathways at the vasculature, but also provides an extra barrier for molecules and cells to cross before entering the brain (Abbott et al., 2010; Li and Fu, 2011).

The BBB is responsible for the control of cellular and molecular exchanges between the blood and the brain. It keeps the ionic homeostasis in the CNS for synaptic signaling and maintains a stable environment for neural functions (Abbott et al., 2010; Deli, 2011; Blanchette and Daneman, 2015). Additionally, the BBB is responsible for the protection of the CNS against toxic substances, provides nutrients for the cells of the CNS and a communication interface between the periphery and the brain (Abbott et al., 2010; Blanchette and Daneman, 2015). An important feature of brain ECs is their multilevel protection system, which makes the $\mathrm{BBB}$ one of the best gatekeepers of the brain (Figure 2).

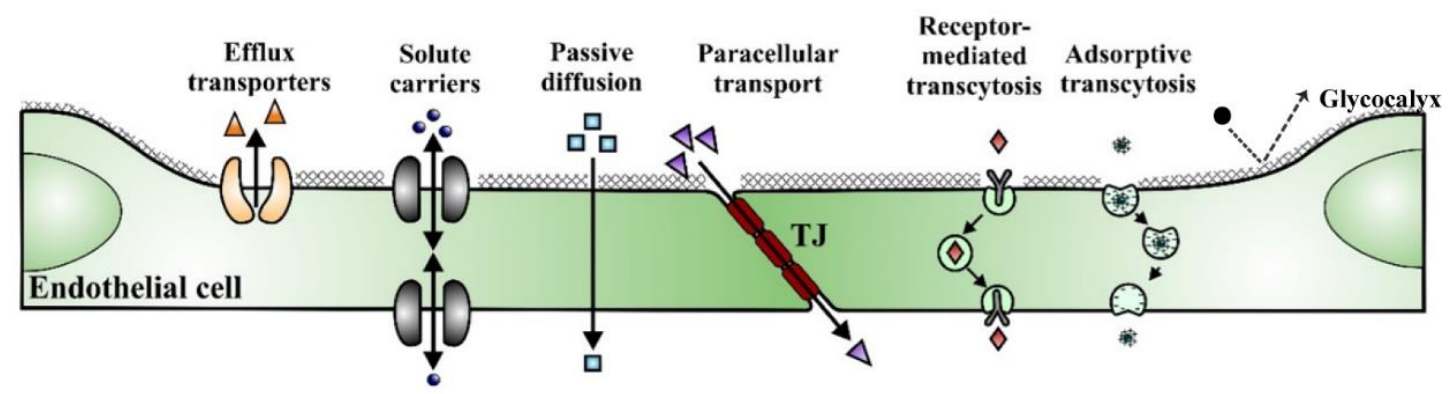

Figure 2. Transport pathways of brain endothelial cells forming the blood-brain barrier. Paracellular transport is restricted by tight junctions (TJ). Transcellular transport is facilitated by solute carriers, receptor-mediated transcytosis, adsorptive transcytosis or via passive diffusion for lipophilic molecules. Efflux transporters block the entry of harmful substances and xenobiotics, while stopping many pharmaceuticals too to enter the brain (illustration adapted from CamposBedolla et al., 2014).

The strong intercellular connection between the ECs is formed by the tight junctions (TJ), which regulate the paracellular transport. The lack of fenestrae and the low levels of transcytosis restrict the transcellular passage of molecules (Abbott et al., 2010; Deli, 2011). The specific influx and efflux transporters regulate the transport of nutrients to the brain, and the removal of unneeded or harmful substances (Campos-Bedolla et al., 2014). Another element of the defense system at the BBB is the negative surface charge of ECs, which derives from the negatively charged lipid head groups and the glycocalyx. This physical barrier regulating the transfer of many molecules and participating as a 
shield in pathologies ( $\mathrm{Li}$ and $\mathrm{Fu}, 2011$; Kutuzov, et al., 2018; Ando et al., 2018; ) will be discussed in a separate section (section no. 1.2).

The paracellular BBB permeability is mainly controlled by the intercellular junctions. These networks include adherens and TJ proteins (Abbott et al., 2010). There are different families of integral transmembrane TJ proteins in the brain endothelial cells: occludin, claudins and junctional adhesion molecules (JAMs) (Figure 3) ( Deli et al,. 2009; Abbott et al., 2010).

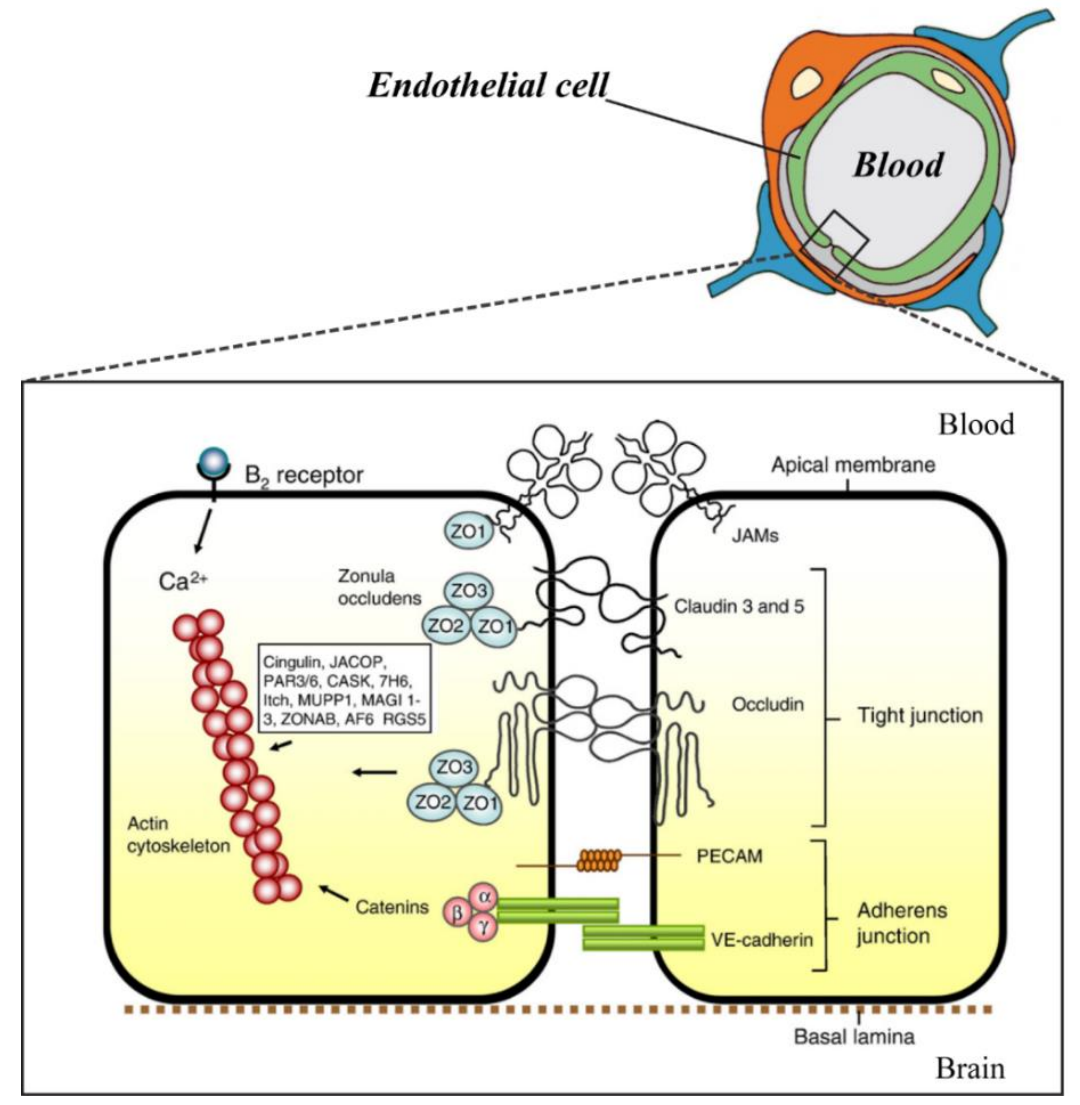

Figure 3. Junctional proteins between brain endothelial cells. ZO: zonula occludens junctional associated molecules. JAM: Junctional adhesion molecule. PECAM and VE-cadherin connect intracellularly to catenins, like $\beta$-catenin (Illustration adapted from Abbott et al., 2010 and Sweeney, et al., 2016. Brain capillary was drawn by Gergő Porkoláb).

Claudins are considered the most important TJ proteins to maintain the barrier integrity, from which the isoform 5 is the most abundant in brain ECs (Deli, 2009; Abbott et al., 2010). The claudins and occludin are interconnected to the actin cytoskeleton by the junction-associated zonula occludens proteins (ZO-1, -2 and -3). The vascular endothelial cadherin (VE-cadherin) adherens junction protein contributes to stabilization of the junctions is and anchored to the actin microfilaments by $\beta$-catenin (Abbott et al., 2010). 
The molecule and cellular passage between the blood and the brain is closely controlled by the brain ECs. Their TJs creates cell polarity resulting in different luminal and abluminal cell membrane and membrane protein composition. In the transcellular transport across the BBB several pathways are involved (Figure 2). The solute carriers (SLC) and efflux transporters are highly expressed in the brain ECs both in the luminal or in the abluminal side (Daneman and Prat, 2015). The SLCs are responsible for the transport of nutrients (amino acids, fatty acids, vitamins or sugars) to the brain, but they can also mediate the transport of metabolites from the brain to the blood (Campos-Bedolla et al., 2014). Another unique BBB characteristic of the barrier is the presence of efflux pumps on the brain ECs. These are the members of the ATP-binding cassette (ABC) transporter family, such as the P-glycoprotein (Pgp/ABCB1), the breast cancer resistance protein (BCRP/ABCG2), the multidrug resistance associated proteins (MRPs/ABCCs) or belong to the SLC family, like the organic acid transporters (OATPs) (Deli, 2011; Veszelka et al., 2018). These pumps work against the concentration gradient to prevent the accumulation or entry of toxic molecules to the brain, but also prevent the treatment of many neurological diseases by blocking the entry of therapeutic drugs to the CNS (Daneman and Prat, 2015). The receptor-mediated transcytosis has an important function in the transport of proteins and peptides, such as transferrin, insulin, leptin or low-density lipoproteins from the blood to the brain (Abbott et al., 2010).

The BBB is a dynamic system that can respond to changes through different pathways. Such pathways include changes in the expression of junctional proteins, transporters, or enzymes. These regulations correspond to the requirements of the brain, whether for protection, nutrient supply, or repair. Several neurodegenerative diseases, among them stroke, multiple sclerosis, Alzheimer's disease, depression, or brain trauma are known to affect the BBB. Since the restrictive nature of the BBB is an obstacle for successful delivery of drugs to the CNS, therefore the treatment of several of these diseases is unsolved or complicated. There is an increasing need to find novel strategies to target drug molecules to the brain. One of this re-discovered field of study is targeting based on molecule charge.

\subsection{Negative surface charge of brain endothelial cells: a defense system and a regulator of $\mathrm{BBB}$ permeability}

In addition to the physical defense mechanisms provided by TJs, and chemical protection by efflux pumps and BBB metabolic enzymes (Deli, 2011), the fourth major 
line of defense is provided by the negative surface charge of ECs derived from the special composition of their membrane lipids and the endothelial surface glycocalyx (ESG).

Blood flow induces mechanical shear to the surface of the brain ECs, which via mechanosensors modulate signaling pathways, gene expression, endothelial function and morphology (Fu and Tarbell, 2013; Zeng et al., 2018). ESG is a sugar-protein matrix like layer covering the EC surface that is mainly composed of proteoglycans, glycoproteins, and glycos-aminoglycans. The unique location, composition and structure of ESG make it a negatively charged physical barrier on the surface of ECs (Zeng et al., 2018).

The surface charge of brain ECs is more negative than other vascular ECs, which is partly related to their higher level of negatively charged phosphatidylserine and phosphatidylinositol in their cell membrane (Ribeiro et al., 2012). In addition to this, the negative surface charge is also derived from the sulfate and sialic acid residues of the ESG (Hervé et al., 2008; Fu and Tarbell, 2013).The protective role of ESG is well known in the cardiovascular system, and damage of this surface layer was demonstrated in diseases and pathologies like atherosclerosis, ischemia, inflammation, bacterial and viral infection (van den Berg et al., 2006). Recently it has been proven that the ESG at the BBB is more robust than in the lung or the liver and remains more intact even in pathological conditions, like sepsis (Ando et al., 2018).

The ESG is mainly composed of glycoproteins and proteoglycans which consist of core proteins and long glycosaminoglycan (GAGs) side chains attached to them. The three negatively charged GAGs present in the glycocalyx of ECs are hyaluronic acid (HA), chondroitin sulfate (CS), and heparan sulfate (HS) (Figure 4B) (Fu and Tarbell, 2013). HS is the most abundant endothelial GAG, and is attached to core proteins such as transmembrane proteins syndecans and the membrane-bound protein glypican ( $\mathrm{Fu}$ and Tarbell, 2013; Zeng et al., 2018). These core proteins communicate with cytoplasmic proteins and help in intracellular signal transduction processes. In addition, the negatively charged components of the GAGs bind plasma proteins and cationic components present in the circulation (Zeng et al., 2018). A recent in vivo study highlights the denser structure of glycocalyx of microvessels in the brain (Figure 4A) as compared with other ECs (Ando et al., 2018). Based on this and other observations the ESG structure is clearly associated with brain EC protection as a defense component of the BBB. 


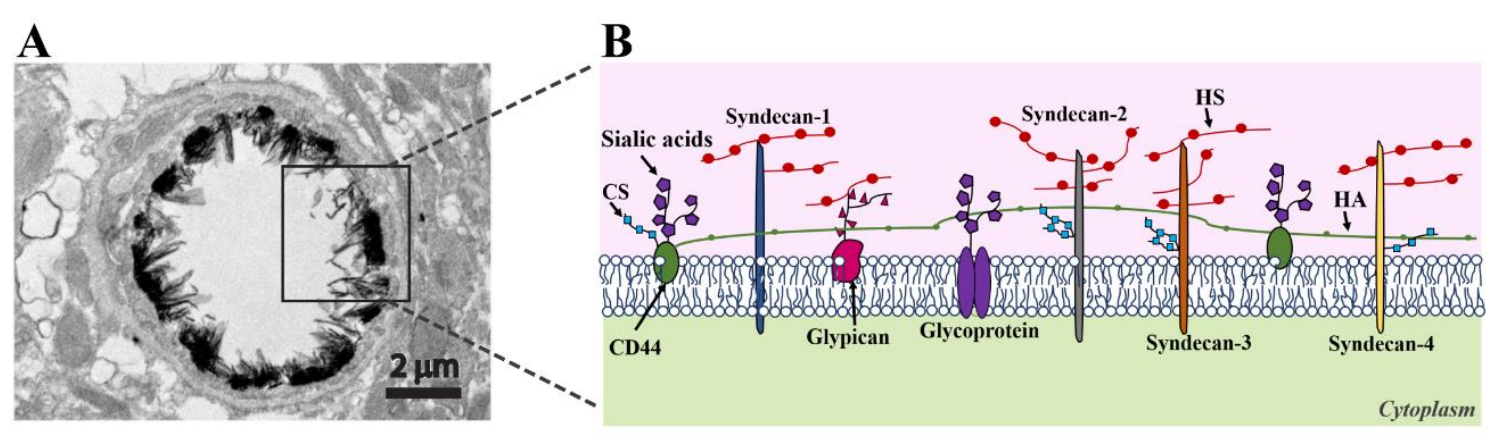

Figure 4. Illustration of the brain endothelial surface glycocalyx. (A) Transmission electron microscopic analysis of cerebral continuous capillaries with lanthanum nitrate staining (adapted from Ando et al., 2018). (B) Drawing representing ESG core proteins, glycoproteins and glycosaminoglycans. HA: hyaluronic acid, HS: heparan sulfate, CS: chondroitin sulfate.

Several potential drugs have failed as possible therapeutics, due to their size or chemical properties, which made them unable to cross the BBB (Deli, 2011). Besides understanding different efflux pump and SLC transporter functions, it is important to understand how drugs directly interact with the endothelial cell surface: both with the surface glycocalyx or with the lipid membrane. As we mentioned above, the surface of brain ECs is negatively charged due to the phospholipid head groups and the ESG. The lipid composition of the brain endothelial cell membrane consists of $70-80 \%$ of different phospholipid species (Tewes and Galla, 2001; Campbell et al., 2014). This lipid composition is unique and due to its high content of phosphatidylinositol and phosphatidylserine very negatively charged, compared with other endothelial cells (Ribeiro et al., 2012). Sphingomyelin and phosphatidylcholine, abundant lipid species at the BBB that are structurally similar but functionally different, have the capability to alter phospholipid organization within the membrane and with cholesterol interactions (Campbell et al., 2014). These membrane alterations can influence the capacity of drugs to interact with the lipids of the $\mathrm{BBB}$, and the ability to form hydrogen bonds, therefore might affect the permeability of lipophilic therapeutic drugs (Campbell et al., 2014).

To better understand how a cationic and lipophilic clinically used molecule interact at the level of the BBB, and change the permeability of another charged molecule, we selected as a model agent lidocaine. Lipophilic drugs, like anaesthetics, interact with the phospholipid membranes through an asymmetric insertion into one side of the phospholipid bilayer which increases membrane fluidity (Seeman, 1972; Sheetz and Singer, 1974). Lidocaine is a lipophilic drug that has anti-hyperalgesic, analgesic and antiinflammatory properties, and is used as antiarrhytmic medicine and also as a local anaesthetic substance (Baughman et al., 1992; Daykin, 2017; Dan et al., 2018). After 
being administered intravenously as an antiarrhytmic drug, lidocaine dissociates to a positively charged quaternary amine and to an uncharged base, creating an in vivo equilibrium between the uncharged and charged molecules (Tsuchiya and Mizogami, 2013). It is not fully understood how lidocaine act, but it is clear that it interacts with the lipid membranes (Weizenmann et al., 2012), changing their fluidity, micro-viscosity and permeability (Högberg and Lyubartsev, 2008; Tsuchiya and Mizogami, 2013). We investigated some of these aspects in our experiments using BBB culture models.

Another physical factor to have in consideration when talking about drug permeability is the endothelial surface glycocalyx. As mentioned above, the ESG is highly negatively charged due to its sulfate and sialic acid content (Figure 4). The structural complexity and the negative surface charge of the ESG at the BBB not only provides an extra barrier, but also regulates the penetration of large molecules (Kutuzov, et al, 2018), charged drugs to the CNS (Hervé et al., 2008; Li and Fu, 2011) and nanoparticles (Mészáros et al., 2018). Although this is a relatively unexplored area of BBB research, the unique and rich phospholipid bilayer and the surface glycocalyx on brain ECs resulting in the negative surface charge are important factors to consider for the BBB penetration of therapeutic drugs.

\subsection{Blood-brain barrier modeling}

Investigation of the BBB and its modeling go back to more than 100 years and span from in silico methods to in vivo models and human investigations. A particular area of $\mathrm{BBB}$ research is related to the estimation of brain penetration during drug discovery and development (Veszelka et al., 2011). When a new target drug is identified with the aim to treat diseases of the brain, it needs to cross the BBB first, therefore chemical structure, size, pump ligand properties, charge and lipophilicity all need to be considered. During drug development there are two major stages, the pre-clinical and clinical tests. The pre-clinical phase starts after chemically appropriate candidates are found with the help of in silico modeling. After this step, the passage of candidate drugs is tested on artificial membranes (Avdeef et al., 2015). In vitro BBB models serve as the next step in complexity by enabling the investigation of the drug permeability to be performed on cell cultures (Deli et al., 2005; Veszelka et al., 2011). Here the two-compartment inserts serve to model the passage of the target molecules from the vessel lumen (blood compartment, top) to the parenchyma (brain compartment, bottom) (Figure 5). These models are usually composed of brain EC cell lines or primary cells or stem cells, in mono-culture or in co- 
culture with astroglia cells and pericytes. After the candidate drug has been chosen, in vivo animal tests follow creating the basis, for clinical studies in patients (Veszelka et al., 2011). We should note, that in addition to drug development and pharmacological applications, cell culture models are excellent tools to study BBB physiology as well as pathology (Deli et al., 2005).

\subsubsection{Type of cell models}

Numerous immortalized cell lines have been used to establish BBB models (Deli et al., 2005; Veszelka et al., 2011; Avdeef et al., 2015). Most models are derived from rodent primary cells, but several human cell lines have also been established. One of the most used human brain EC line is the hCMEC/D3 (Weksler et al., 2005 and 2013). These models are simplified BBB models, while they usually keep their endothelial characteristics, several properties, especially the paracellular tightness is weaker than that of primary cell-based BBB models (Helms et al., 2016; Veszelka et al., 2018).

Many of the most current successful BBB in vitro models were developed based on primary ECs, due to their high transendothelial electrical resistance (TEER) values and low permeability (Veszelka et al., 2011; Helms et al., 2016). The primary cells can provide the most similar characteristics to in vivo BBB in terms of drug permeability (Nakagawa et al., 2009). However, this type of cell culture requires special skills for cell isolation and culture, and the availability of human primary cells is scarce. In the current study, we used the rat primary BBB model developed by Nakagawa et al. and published in 2009. The primary endothelial cells are freshly isolated and selected from possible contaminating cell types using puromycin (Perrière et al., 2005). Brain pericytes and astrocytes are also freshly isolated, then the three cell types are kept as a co-culture for several days to reach enhanced BBB properties.

In the last three decades mostly in vitro BBB models from primary cells or immortalized brain ECs were used. The inherent limitations of these models derived from animal tissues or cells is obvious in the context of drug development for use in human patients. This need of human cell-based co-culture BBB models led to the introduction of stem cell technology in the research field (Helms et al., 2016). Human stem cells are promising sources of cells, due to the possibility to differentiate them into brain endothelial cells, pericytes and astrocytes (Lippmann et al., 2012; Cecchelli et al., 2014). Human induced pluripotent stem cells (hiPSC) have unlimited self-renewal and the capacity to differentiate into several cell types, depending on the added factors (Delsing 
et al., 2020). A hiPSC BBB model has been established expressing tight barrier properties (Lippmann et al., 2012) and was further characterized using various differentation methods (Appelt-Menzel et al., 2020). However, criticism was raised regarding this model showing neuroepithelial markers, morphology and function, including extremely high resistance (Lu et al., 2019; Lippmann et al., 2020).

In the present study, a human BBB model generated from cord blood-derived hematopoietic stem cells was used. The stem-cell derived ECs were differentiated to brain-like endothelial cells (BLECs) by co-culture with bovine brain pericytes to induce BBB properties (Cecchelli et al., 2014). The human endothelial cells after differentiation expressed typical EC markers including platelet endothelial cell adhesion molecule (PECAM1), vascular endothelial cadherin (VE-cadherin), von Willebrand factor (vWF) and internalized low density lipoprotein (Cecchelli et al., 2014). The BLECs expressed several BBB marker genes and proteins, such as junctional proteins, efflux pumps and solute carriers following a 6-day co-culture with bovine brain PCs (Cecchelli et al., 2014; Heymans et al., 2020). This model is a stable and reproducible human BBB model, that can keep the BBB properties for up to 20 days. This human BBB culture model has also been characterized in static conditions by gene sequencing (Heymans et al., 2020).

\subsubsection{Type of cell culture setups}

The most often used type of in vitro BBB models for permeability studies is based on cell culture inserts (Deli et al., 2005). The technique was developed in the 1980s for epithelial cell models and later adapted in BBB research. In this setup, the cell culture is grown on the filter membrane of the inserts and positioned in the wells of culture plates (Figure 5). It is a vertical system which is composed of a microporous semipermeable membrane (on which cells can be seeded) that separates the upper and lower compartment, which in the case of BBB models mimics the vascular and brain parenchyma compartments (Figure 5).

This setup allows the co-culture of the brain ECs with the NVU cells and made possible the development of the first culture model using not only astrocytes to induce BBB properties in ECs but pericytes as well (Nakagawa et al., 2009). BBB culture models on inserts have been extensively used to study permeability in physiological and pathological conditions, as well as to study the permeability of drugs across the BBB (Deli et al., 2005; Veszelka et al., 2011; Helms et al., 2016). 
A

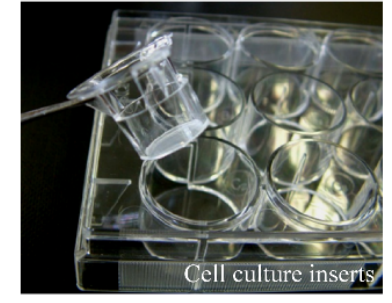

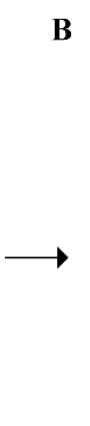

T
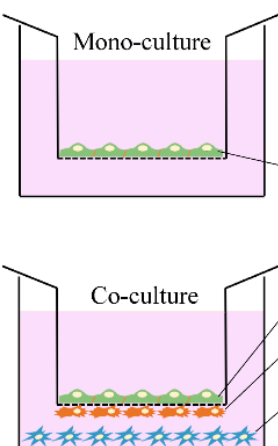

C

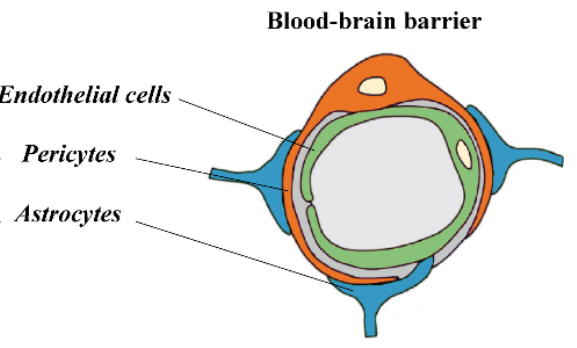

Figure 5. Illustration of BBB culture models on inserts. (A) Commercially available hangingtype cell culture inserts in a multiwell culture plate. (B) Drawing showing BBB culture models: a mono-culture where only the brain endothelial cells are on the membrane; a co-culture where brain endothelial cells are cultured on the top of the membrane, brain pericytes on the opposite side of the membrane, and astrocytes on the bottom of the wells of the culture plates. The coculture allows similar cell interaction as shown in the brain capillary. (C) Representation of a brain microvessel composed of brain endothelial cells surrounded by pericytes and astrocytes. (Illustration of the brain capillary was drawn by Gergö Porkoláb.)

This limitation was solved by the development of the so-called dynamic BBB models in the 1990s by the introduction of fluid flow. The first dynamic BBB models applied hollow fiber cartridges (Cucullo et al., 2011; Avdeef et al., 2015), which did not allow the measurement of TEER and the visualization of the cells. The use of lab-on-achip (LOC) microfluidic devices for modeling the BBB emerged in the last decade. Most LOCs for these dynamic BBB models are composed of polydimethylsiloxane (PDMS), a transparent polymer, which allows visualization of the cell layer, while the addition of electrodes enables TEER registration (Booth et al., 2012). In the last nine years a large number of new microfluidic LOC system setups were developed. The biggest advantage of LOCs is that this new cell culture approach made possible the establishment of BBB models expressing more physiological features (Helms et al., 2016). In a dynamic setup a flow of medium can be set, and brain ECs can be kept under fluid flow, while the pericytes and/or astrocytes are cultured in a separate channel separated by a membrane (van der Helm et al., 2016). Multiple LOC device units can be connected to each other (Maoz et al., 2018). Hydrogel based models with a lumen are also available and provide a new tool to study cerebral vessels (Herland et al.,2016). One of the disadvantages of the LOCs is that most of the dynamic BBB models do not combine the possibility to measure permeability and TEER, and visualization of the cell layer which are all crucial to characterize barrier integrity. In 2016 our team developed a versatile LOC device (Figure 6), to model different biological barriers, including the BBB (Walter et al., 2016). 

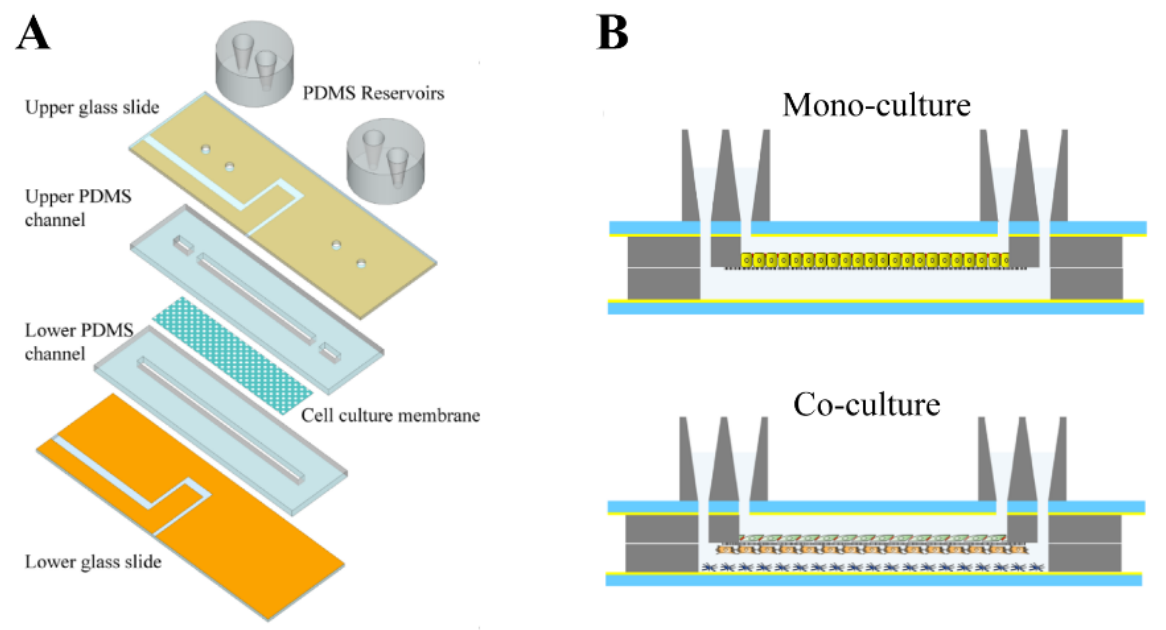

Figure 6. (A) Structural assembly of the microfluidic device showing all layers. PDMS reservoirs holding the inlet and outlet tubes are fixed to the top of the device. The porous cell culture membrane is situated between the upper and the lower channels made of PDMS. The layers are sandwiched by two glass slides with gold electrodes. (B) Microfluidic device with mono or coculture barrier models (adapted from Walter et al.,2016).

With this device it is possible to apply a constant fluid flow. This LOC device has several features that are important to characterize the function and integrity of the BBB. We can measure TEER and permeability for different molecular markers. It is also possible to visualize the cell monolayers under microscope. In addition, the LOC device can be disassembled and the membrane containing the cells can be used for fluorescent labeling (Walter et al., 2016). This device, which we have used in our studies, is a cutting edge bioengineered LOC combining all the features that are important for the characterization and study of a dynamic BBB model.

\subsection{Techniques to assess blood-brain barrier integrity}

\subsubsection{Transendothelial electrical resistance}

TEER is one of the most sensitive methods to measure the paracellular tightness of cell culture barrier models for small inorganic ions, i.e. $\mathrm{Na}^{+}$and $\mathrm{Cl}^{-}$which are present in experimental media and buffers. It can be defined as a measure of electrical/ohmic resistance to ion flow across the cell monolayer (Benson et al., 2013), and used as a method to evaluate the barrier tightness of in vitro BBB models (Deli et al., 2005; Helms et al., 2016). In accordance with Ohm's law, it is a direct current (DC) approach: voltage $(\mathrm{U})$ is applied to two electrodes, from which one is above, the other one is under the cell layer enabling the ion current (I) measurement across the monolayer resulting in the recording of ohmic resistance $(\mathrm{R}=\mathrm{U} / \mathrm{I})$ (Benson et al., 2013). Using DC for TEER 
measurement can result in the accumulation of ions at the measuring electrode and cell layer, therefore commonly used instruments, like the Epithelial Voltohmmeter (EVOM; World Precision Instruments) operate with alternate current (AC) at a very low, $12.5 \mathrm{~Hz}$ frequency. When we measure TEER with $\mathrm{AC}$ we register impedance. In this method the capacitance of the cell layer is also considered when calculating resistance. The total impedance reflects not only the TEER (paracellular ion pathway) of the cell layer but the resistance of the membrane (transcellular ion pathway), the medium itself and the surface where the electrode and medium meet (Benson et al., 2013). The most common electrode type to measure TEER of BBB models grown on cell culture inserts is the chopstick configuration (Figure 7A). In the LOC devices built-in electrode pairs are needed. In the microfluidic device developed by our team previously, to measure TEER the top and bottom slides were coated with thin gold layers that provided the necessary conductivity for the measurement (Figure 7B), as well as a good visibility to monitor the cells by microscope.

A

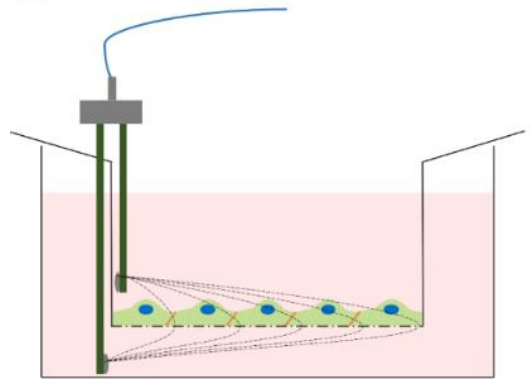

B

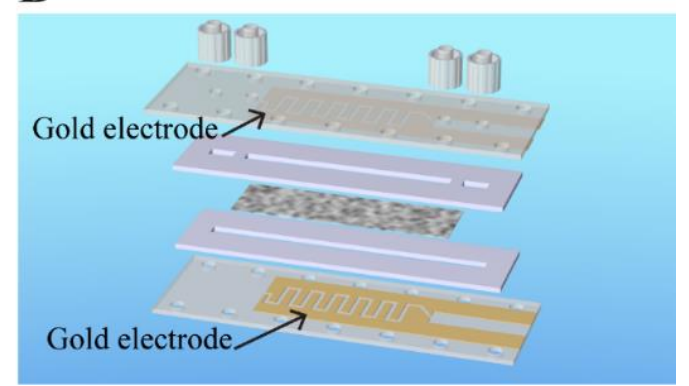

Figure 7. Illustration of the different electrode types to measure transendothelial electrical resistance. (A) Chopstick electrodes and measurement of ion flow across cell monolayers. (B) Illustration of the lab-on-a-chip device with the gold electrodes in the top and bottom slide.

In addition, TEER measurement is widely used as a quality control to select culture inserts with consistent and comparable cell monolayers representing similar integrity for experiments (Deli et al., 2005; Helms et al., 2016). This method is employed in studies to identify agents/drugs that modulate barrier tightness (Walter et al., 2015a; Bocsik et $a l ., 2016)$. In BBB models, like the hCMEC/D3 cell line or the primary co-culture BBB model, TEER can be increased by the addition of molecules elevating barrier tightness, like lithium chloride (Veszelka et al., 2018), cAMP or hydrocortisone (Deli et al., 2005). Shear stress generated by fluid flow is an important physiological factor tightening endothelial barriers as it was proven on a hollow fiber-based dynamic BBB model (Cucullo et al., 2011) and our LOC device (Walter et al., 2016). 


\subsubsection{Permeability assay for marker molecules}

The other most commonly used method to assess the tightness of culture models of the BBB for molecules is the permeability assay (Deli et al., 2005;). Permeability measurements can be used not only to determine brain endothelial barrier tightness (evaluation of the functionality of complex tight junction proteins) using well-known paracellular integrity markers, but also to evaluate BBB penetration of therapeutic drugs, nutrients or nutraceuticals (Youdim et al., 2003; Deli et al., 2005; Campos-Bedolla et al., 2014; Avdeef et al., 2015). Different transport pathways contribute to the BBB crossing of specific compounds: passive mechanisms, like paracellular diffusion for small hydrophilic and transcellular diffusion for lipophilic molecules, as well as active mechanisms, such as carrier-mediated transport via solute carriers and transcytosis by receptor-mediated or adsorptive-mediated transcytotic pathways (Abbott et al., 2010; Deli, 2011). Depending on their characteristics, size and lipophilicity, most nutrients and therapeutic CNS drugs are transported through either transcellular transport pathways or passive permeation across the lipid plasma membrane (Deli, 2011).

The BBB permeability in vitro is based on the transport rate of a molecule across a confluent brain EC monolayer, which is seeded on the highly permeable membrane of a cell culture insert or a LOC device. In both cases the cells on the membrane form the interface between two fluid compartments (Figures 5 and 6), from which the top compartment mimics the blood and the bottom compartment mimics the brain side. The test compound is added to the donor compartment (which can be one of the two compartments) and is then allowed to be transported across the cell monolayer to the receiver compartment in a defined amount of time ( Youdim et al., 2003; Campos-Bedolla et al., 2014). The permeability experiment ends with sample collection and measurement of the amount of transferred molecule that is required for calculating BBB permeability. The permeability of the BBB models for a given molecule is calculated by two different types of methods with either consideration of a cell-free insert/LOC or not: the endothelial permeability coefficient $\left(\mathrm{P}_{\mathrm{e}}\right)$ and the apparent permeability coefficient $\left(\mathrm{P}_{\mathrm{app}}\right)$, respectively. Permeability coefficients describes the speed at which a certain compound crosses the BBB. In practice, the passage of paracellular marker molecules or efflux pump ligands across BBB models is characterized by low permeability coefficients values and that of lipophilic molecules with high values (Nakagawa et al., 2009; Veszelka et al., 2018). 


\section{Aims}

The BBB, a dynamic interface separating the CNS from the blood circulation is one of the most complex barriers in the human body. Brain endothelial cells have special properties ensuring the protection of the brain, like tight interendothelial junctions, low amount of intracellular vesicles, specialized and polarized influx and efflux transport systems (Deli, 2011; Campos-Bedolla et al., 2014). Besides these features, the negative surface charge derived from plasma membrane phospholipids and the surface glycocalyx of brain ECs are not only fundamental elements of the physical defense system of the BBB but are suggested by some studies to be important regulators of the passage of charged molecules across the BBB. Despite of the potential importance of the negative surface charge in both physiology and pathology, this area is not in the focus of present investigations. How changes in surface charge may affect the functions of brain endothelial cells and BBB integrity is not yet fully understood. Therefore, the major aims of the studies described in this thesis were the following:

1. To characterize not only the barrier properties but also the glycocalyx morphology of three in vitro $\mathrm{BBB}$ models using cell culture inserts and a LOC device, for the first time. Our goal was to test the widely used rat primary cell based and human stem cell derived co-culture models, as well as the human hCMEC/D3 cell line, and visualize their surface glycocalyx with the help of culture inserts and our LOC device.

2. To directly measure and modulate the surface charge of brain ECs. We tested neuraminidase enzyme, which specifically removes sialic acid residues from ESG and makes the surface charge more positive. We also aimed to change the surface charge of BBB models by a membrane intercalating therapeutic cationic drug, lidocaine and study its effects on barrier properties and the permeability of charged molecules. In these experiments we used hCMEC/D3 cell line as a simplified BBB model and rat primary cell based co-culture BBB model.

3. Because the stem cell based human BBB co-culture model was only investigated in static conditions so far, to investigate the effect of fluid flow on the barrier integrity, surface charge and ESG of this model using both functional assays and transcriptomics. 


\section{Materials and Methods}

\subsection{Animals}

Organ harvest from rats was performed according to the regulations of the 1998. XXVIII. Hungarian law and the EU Directive 2010/63/EU about animal protection and welfare. For primary cell isolations brain tissues were obtained from 4-week-old and 1day-old Wistar rats (Harlan Laboratories, United Kingdom) of both sexes. Animals were kept under a $12 \mathrm{~h}$ light/dark cycle and fed on standard rodent chow and water ad libitum in the conventional animal house of the Biological Research Centre. Following the 3Rrule all efforts were made to minimize animal number and suffering and pain.

\subsection{Materials}

All reagents were purchased from Sigma-Aldrich Ltd. Hungary (part of Merck Life Science), unless otherwise indicated.

\subsection{Cell cultures}

\subsubsection{BBB models on culture inserts}

The cell culture inserts allowed us to have a standard environment for all types of cell cultures, allowing to construct mono, double and triple co-culture models (Figure 5). The double and triple co-culture models aim to mimic the in vivo conditions, where a dynamic interaction between brain ECs, astrocytes and pericytes is present (Abbott et al., 2006; Nakagawa et al., 2009). We used for all experiments inserts with transparent membranes (\#3460, $0.4 \mu \mathrm{M}$ pore size, polyester membrane, Corning Costar).

\subsection{2. $\quad$ hCMEC/D3 human brain endothelial cell line}

The human hCMEC/D3 brain endothelial cell line (Weksler et al., 2005) was purchased from Merck Millipore. The cultures of hCMEC/D3 ( $\leq$ passage number 35) were grown at $37^{\circ} \mathrm{C}, 5 \% \mathrm{CO}_{2}$ in $\mathrm{MCDB} 131$ medium (Pan Biotech, Germany) supplemented with $5 \%$ fetal bovine serum $(\mathrm{FBS})$, GlutaMAX $(100 \times$, Life Technologies, USA), lipid supplement (100 $\times$, Life Technologies, USA), $10 \mu \mathrm{g} / \mathrm{ml}$ ascorbic acid, $550 \mathrm{nM}$ hydrocortisone, $100 \mu \mathrm{g} / \mathrm{ml}$ heparin, $1 \mathrm{ng} / \mathrm{ml}$ basic fibroblast growth factor (bFGF, Roche, USA), $5 \mu \mathrm{g} / \mathrm{ml}$ insulin-transferrin-selenium (ITS) supplement $(100 \times$, PanBiotech, Germany), $10 \mathrm{mM}$ HEPES and gentamycin $(50 \mu \mathrm{g} / \mathrm{ml})$. Medium change was 
performed every two or three days. When cells reached $90 \%$ confluence, they were passaged to rat tail collagen-coated cell culture clear inserts (Figure 5, monoculture) and/or to the membrane of the LOC device (Figure 6B, monoculture). Before each experiment the medium was supplemented with $10 \mathrm{mM} \mathrm{LiCl}$ for $24 \mathrm{~h}$ to improve BBB properties (Weksler et al., 2013; Veszelka et al., 2018).

\subsubsection{Primary cell cultures and rat BBB co-culture model}

The isolation of primary rat brain endothelial cells (RBEC), glial cells and pericytes and the construction of the in vitro $\mathrm{BBB}$ model were done according to the method described previously (Nakagawa et al., 2009; Walter et al., 2016; Veszelka et al., 2018). After the isolation, primary brain ECs were seeded on petri dishes (Corning Costar, USA) coated with a mix of collagen type IV and fibronectin $(100 \mu \mathrm{g} / \mathrm{ml}$ each $)$ in sterile distilled water. The cells were cultured in DMEM/F-12 (Gibco, Thermofisher, USA), 15\% plasma derived bovine serum (PDS, First Link, UK), $100 \mu \mathrm{g} / \mathrm{ml}$ heparin, $1 \%$ ITS supplement, $1 \mathrm{ng} / \mathrm{ml} \mathrm{bFGF}, 10 \mathrm{mM}$ HEPES and $50 \mu \mathrm{g} / \mathrm{ml}$ gentamycin. For the first 3 days of culture $3 \mu \mathrm{g} / \mathrm{ml}$ puromycin was added to the medium to eliminate P-glycoprotein negative, contaminating cell types (Perrière et al., 2005).

Primary rat brain pericytes were isolated using the same method as described previously, except that pericytes were seeded to uncoated petri dishes (Corning, Costar, USA). Pericytes were passaged once to uncoated dishes and were used in passage number two. Primary cultures of glial cells were prepared from one-day-old Wistar rats and passaged to 12-well plates (Corning, Costar, USA) coated with $100 \mu \mathrm{g} / \mathrm{ml}$ collagen type IV in sterile distilled water. Cultures of rat glial cells were maintained for 2 weeks before using them for the triple co-culture model. Pericytes and glial cells were kept in low glucose Dulbecco's modified Eagle's medium (DMEM; Gibco, Thermofisher, USA) supplemented with 10\% FBS (Gibco, Life Technologies, USA) and $50 \mu \mathrm{g} / \mathrm{ml}$ gentamycin.

For the primary cell based co-culture BBB model the three cell types were separately cultured then assembled as described before (Nakagawa et al., 2009). Briefly, pericytes at passage number two were seeded at a density of $1.5 \times 10^{4} / \mathrm{cm}^{2}$ to the bottom of the membranes of cell culture inserts or LOC devices, while RBECs were passaged to the top of the membranes at a cell number of $7.5 \times 10^{4} / \mathrm{cm}^{2}$. The inserts were placed into 12-well plates containing the glial cultures (Figure 5, co-culture). In the case of the LOC device the glial cells were added to the bottom compartment (Figure 6, co-culture). The 
triple BBB co-culture model received endothelial culture medium supplemented with $550 \mathrm{nM}$ hydrocortisone in both compartments and was cultured together for 4 to 5 days (Nakagawa et al., 2009). After the in vitro BBB model was established, TEER measurements, permeability assays and immunohistochemistry were performed. One day before the permeability assay cells were treated with chlorophenylthio-adenosine-3,5cyclic monophosphate $(250 \mu \mathrm{M}, \mathrm{CPT}$-cAMP) and phosphodiesterase inhibitor RO 201724 (17.5 $\mu$ M, Roche, Switzerland) to tighten junctions and elevate resistance (Deli et al., 2005; Perrière et al., 2005).

\subsubsection{Human BBB co-culture model}

The human BBB model was described by Cecchelli et al., in 2014, and consists of stem cell derived ECs in co-culture with bovine brain pericytes. Based on a cooperation between our group and the French partners from University of Artois (BtRAIN MSCA ITN), cells were prepared in Lens, France and shipped to our laboratory. The isolation of $\mathrm{CD} 34^{+}$stem cells required the collection of human umbilical cord blood. The protocol of stem cell isolation and model use was approved by the French Ministry of Higher Education and Research (CODECOH Number DC2011-1321). All experiments were carried out in accordance with the approved protocol and the World Medical Association Declaration of Helsinki. Briefly, the hematopoietic stem cells were isolated from human cord blood and differentiated to endothelial cells as previously published (Pedroso et al., 2011). The human ECs were seeded onto 0.2\% gelatin (type A, from porcine skin) coated culture dishes and kept in endothelial cell culture medium (ECM, Sciencell, USA) supplemented with $5 \%$ FBS, $1 \%$ endothelial cell growth supplement (ECGS, Sciencell), and gentamycin $(50 \mu \mathrm{g} / \mathrm{ml})$. After reaching confluency, usually 2 days after seeding, human ECs were gently trypsinized and $8 \times 10^{4}$ cells were seeded onto the porous polyester membrane of the LOC device (Figure 8A), for detailed description of the biochip assembly, static and dynamic chip conditions see sections 3.4.1. and 3.4.2., below. The membrane was coated with Matrigel (growth factor reduced BD Matrigel Matrix, BD Biosciences, USA) at a dilution of 1:48. Bovine brain PCs were cultured in $0.2 \%$ gelatin coated dishes in DMEM supplemented with $20 \%$ FBS, $1 \%$ GlutaMAX and gentamycin $(50 \mu \mathrm{g} / \mathrm{ml})$. When cultures reached confluency, PCs were trypsinized and $25 \times 10^{3}$ cells were added to the bottom compartment of the LOC device coated with $0.2 \%$ gelatin (Figure 8A). During co-culture both compartments received endothelial medium. The LOC device with the cells was kept at $37^{\circ} \mathrm{C}$ in a humidified atmosphere and $5 \% \mathrm{CO}_{2}$. 


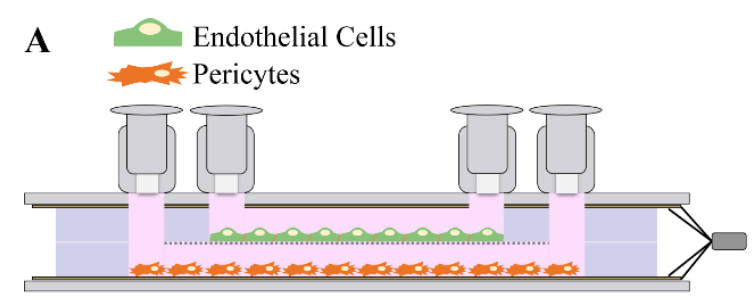

B

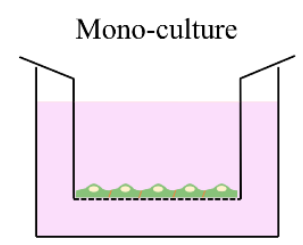

C

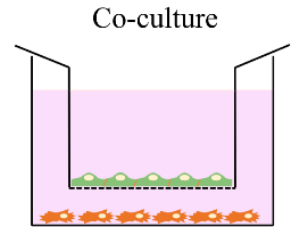

Figure 8. Illustrations of the human BBB model on lab-on-a-chip (LOC) device and cell culture insert. (A) Cross section of the LOC with the human BBB co-culture model: human endothelial cells (ECs) on the top of the membrane and brain pericytes in the bottom channel. (B) Monoculture of human ECs in the cell culture insert. (C) The co-culture model in cell culture insert with human ECs on the top of the membrane and rain pericytes on the bottom of the culture well.

The human BBB co-culture model in static cell culture inserts was the same as described above. In this case the ECs were cultured on the membrane of culture inserts (Figure $8 \mathrm{~B}$ and $\mathrm{C}$ ) coated with Matrigel, at a density of $8 \times 10^{4}$ cells, as described previously (Cecchelli et al., 2014; Heymans et al., 2020). For the mono-culture ECs were not subjected to the effects of another cell type. For the co-culture, brain pericytes were trypsinized and seeded at a concentration of $2.5 \times 10^{4}$ cells on the bottom of $0.2 \%$ gelatincoated 12-well plates (Figure 8C). During the 7 days of culture cells were kept in a $\mathrm{CO}_{2}$ incubator at $37^{\circ} \mathrm{C}$, with $5 \% \mathrm{CO}_{2}$.

\subsection{Lab-on-a-chip device}

\subsubsection{Device fabrication}

The LOC device (Figures 6 and 7)were built as described previously (Walter et al., 2016). Briefly, the top and bottom channels were fabricated from polydimethylsiloxane (PDMS, Sylgard 184, Dow Corning GmbH, Wiesbaden, Germany), separated by a porous membrane (PET, $0.45 \mu \mathrm{m}$ pore size, $2 \times 10^{6} / \mathrm{cm}^{2}$ pore density and $23 \mu \mathrm{m}$ thickness; It4ip, Louvain-la-Neuve, Belgium) (Figure 7). The length, width and height of the top and bottom channels were $36 \mathrm{~mm} \times 2 \mathrm{~mm} \times 1 \mathrm{~mm}$ and $57 \mathrm{~mm} \times 2 \mathrm{~mm} \times 2 \mathrm{~mm}$, respectively. Gold electrodes (thickness: $25 \mathrm{~nm}$ ) were formed on the plastic microscope slides using sputter-coating, providing low resistance to allow TEER measurements and good visibility to monitor cell growth by phase contrast microscopy throughout the whole length of the channel (Walter et al., 2016). The electrodes were linked and connected with copper wires to a 4-channel EVOM instrument. The PDMS channels were sandwiched between the plastic slides and closed with plastic screws (Figure 7). The device was sterilized with oxygen plasma for 5 min and $70 \%$ ethanol for $30 \mathrm{~min}$ before cells were seeded to the system. 


\subsubsection{Static and dynamic condition in the chip device}

To determine the importance of fluid flow on the human BBB model, the coculture of ECs with PCs lasted for 6 days under static condition (Figure 9A) then 24 hours under dynamic condition (Figure 9B).

A

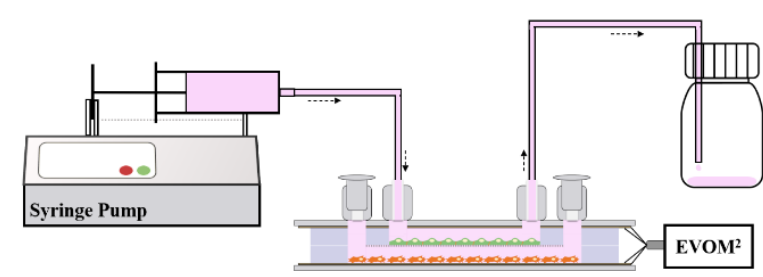

B

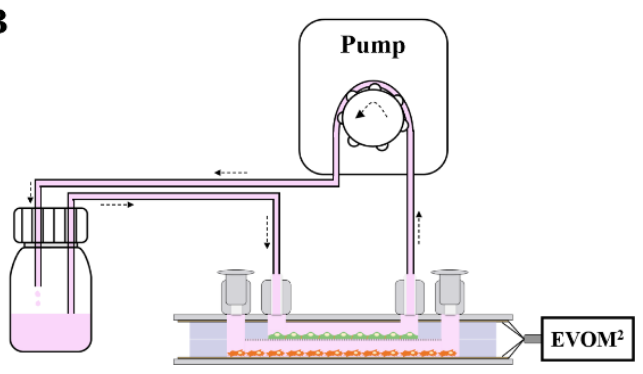

Figure 9. Illustration of the static and dynamic condition in the lab-on-a-chip device. (A) Static condition: a syringe containing the cell culture medium was placed in a syringe pump (on the left), which allowed automatic medium change through the top compartment every 8 hours with a fluid flow of $500 \mu \mathrm{l} / \mathrm{min}$, for $4 \mathrm{~min}$. A reservoir was connected to the LOC to collect the discarded medium. (B) Dynamic condition: the device was connected to a peristaltic pump and a reservoir containing cell culture medium. Fluid flow was applied at a speed of $1 \mathrm{ml} / \mathrm{min}$ for 24 hours.

Cell growth in the LOC device was monitored by phase contrast microscopy (MotiCam 1080, MoticEurope, Spain). TEER was measured every day. For the static condition, a $20 \mathrm{ml}$ plastic disposable syringe with Luer cone (B. Braun, Germany) containing cell culture medium was placed in a syringe pump (Legato 110, KD Scientific, USA) and connected to the inlets/outlets of the LOC device via female Luer locks (Rotilabo, Carl Roth, Germany) using plastic tubes (1 $\mathrm{mm}$ inner, $3 \mathrm{~mm}$ outer diameter, Carl Roth). Upon reaching the $6^{\text {th }}$ day, a constant circulation of culture medium was introduced by a peristaltic pump (Masterflex, Cole-Parmer, USA) at $1 \mathrm{ml} / \mathrm{min}$ flow rate $\left(0.4 \mathrm{dyne} / \mathrm{cm}^{2}\right)$ for 24 hours for the model in dynamic conditions. For the static condition, no change was done. For the first six days of the dynamic condition and all seven days of the static condition the syringe was programmed to change medium above the human EC monolayer every 8 hours at $500 \mu \mathrm{l} / \mathrm{min}$ flow rate. The medium in the lower compartment containing PCs was changed manually every day. Right after this 24-hour static and dynamic condition, we performed barrier integrity studies on the human BBB model, did RNA extraction of BLECs, stained the glycocalyx and measured the surface charge of BLECs. 


\subsection{Cell culture treatments}

\subsubsection{Lidocaine treatment}

For treatments performed on cell cultures a stock solution of lidocaine $(20 \mathrm{mM}$, Sigma L7757) was prepared in a water bath at $30{ }^{\circ} \mathrm{C}$. Stock solutions were always prepared freshly before each experiment. Different dilutions from the lidocaine stock were prepared between 1-1000 $\mu \mathrm{M}$ concentrations in culture medium for cell treatments.

\subsubsection{Neuraminidase treatment}

Neuraminidase from Clostridium perfringens (Sigma N2876) was dissolved in DMEM and aliquots of a $10 \mathrm{U} / \mathrm{ml}$ stock solution were stored at $-20^{\circ} \mathrm{C}$. A new neuraminidase stock vial was thawed before each experiment. For cell treatment neuraminidase was diluted in serum free medium and applied at $0.1,0.3$ and $1 \mathrm{U} / \mathrm{ml}$ concentrations to the cells based on a preliminary study and literature data (Singh et al., 2007). The cells were incubated with neuraminidase for $1 \mathrm{~h}$ at $37^{\circ} \mathrm{C}$. After the treatment cells were washed once with PBS and the experiments were continued with the permeability studies and the zeta measurements.

\subsection{Cell viability assays}

\subsubsection{Impedance measurements}

Kinetics of the adherence and integrity of brain endothelial cell monolayers after lidocaine treatment was monitored by real time impedance measurement (RTCA-SP, ACEA Biosciences, USA). Impedance measurement correlates linearly with cell number, adherence, growth and viability (Walter et al., 2015a). Brain endothelial cells (hCMEC/D3 and RBEC cells) were seeded at a cell number of $5 \times 10^{3} /$ well onto a 96well E-plate with golden electrodes (ACEA Biosciences) and were kept in the $\mathrm{CO}_{2}$ incubator at $37^{\circ} \mathrm{C}$ for $4-5$ days. Cells were treated with $0,1,3,10,30,100,300$ and $1000 \mu \mathrm{M}$ concentrations of lidocaine a few hours after reaching the plateau phase of cell growth. Triton X-100 detergent (1\%) was used to determine $100 \%$ toxicity. Effects of the treatment were followed for 24 hours. 


\subsubsection{MTT and lactate dehydrogenase release assays}

For these assays hCMEC/D3 and RBEC cells were seeded onto 96-well plates (Corning Costar, USA) at a cell number of $5 \times 10^{3} /$ well. Confluent cultures were treated with $0-1000 \mu \mathrm{M}$ of lidocaine for $30 \mathrm{~min}$, or treated with neuraminidase at concentrations of $0.1-1 \mathrm{U} / \mathrm{ml}$. Triton $\mathrm{X}-100(1 \%)$ was used as a reference compound to cause cytotoxicity.

Viable cells convert the yellow MTT dye (3-(4,5-dimethylthiazol2-yl)-2,5diphenyltetrazolium bromide) to purple formazan crystals reflecting metabolic activity. After lidocaine treatment MTT solution $(0.5 \mathrm{mg} / \mathrm{ml})$ was added and cells were incubated for $3 \mathrm{~h}$ at $37^{\circ} \mathrm{C}$. Formazan crystals produced by living cells were dissolved with dimethyl sulfoxide, and absorbance was measured at $592 \mathrm{~nm}$ by a multiwell microplate reader (Fluostar Optima, BMG Labtechnologies, Germany). Cytotoxicity was calculated as a percentage of the control group (cells receiving only medium) in which maximum dye conversion was detected.

In order to investigate membrane damage, the presence of the intracellular lactate dehydrogenase (LDH) enzyme was determined from the culture supernatant using a commercially available kit (Lénárt et al., 2015). After treatment of the cells in serum-free medium, culture supernatants $(50 \mu \mathrm{l})$ were collected and incubated with the reaction mixture for $15 \mathrm{~min}$ on a horizontal shaker according to the manufacturer's protocol (Cytotoxicity detection kit LDH, Roche). Enzyme reaction was stopped with $0.1 \mathrm{M}$ of $\mathrm{HCl}$ and absorbance was measured at $450 \mathrm{~nm}$ wavelength using a multiwell microplate reader (Fluostar Optima, BMG Labtechnologies, Germany). Cytotoxicity was calculated as a percentage of the total $\mathrm{LDH}$ release from cells treated with $1 \%$ Triton $\mathrm{X}-100$ detergent.

\subsection{Evaluation of barrier function and integrity}

\subsubsection{Transendothelial electrical resistance}

The BBB models (hCMEC/D3 mono-cultures, primary cell-based rat and human co-culture models) prepared on inserts received fresh culture medium every second day. To follow the development of the barrier properties of brain endothelial monolayers TEER was measured before every medium change with an EVOM instrument combined with STX-2 electrodes (Figure 7A). TEER was expressed relative to the surface of the inserts $\left(\Omega \times \mathrm{cm}^{2}\right)$, while TEER of cell-free inserts $\left(100 \Omega \times \mathrm{cm}^{2}\right)$ was subtracted from the measured values. TEER before and after lidocaine and neuraminidase treatments were measured in Ringer-Hepes buffer (118 mM NaCl, $4.8 \mathrm{mM} \mathrm{KCl}, 2.5 \mathrm{mM} \mathrm{CaCl}_{2}, 1.2 \mathrm{mM}$ 
$\mathrm{MgSO}_{4}, 5.5 \mathrm{mM}$ D-glucose, $10 \mathrm{mM}$ HEPES, $\mathrm{pH}$ 7.4) supplemented with $1 \%$ bovine serum albumin (BSA) and ITS. This buffer had the same composition as used for the permeability measurements. To decrease fluctuations in TEER values due to temperature change, measurements were performed by placing the culture plates on a heating pad set to $37^{\circ} \mathrm{C}$.

For the human co-culture model in the LOC device, the cells were kept in coculture for 7 days and TEER values were recorded daily. The TEER was measured as described in our previous work (Walter et al., 2016): the LOC electrodes were connected to an $\mathrm{EVOM}^{2}$ instrument and the TEER values were registered.

\subsubsection{Permeability measurement}

Permeability tests on the BBB models on inserts were performed after 4-5 days for the hCMEC/D3 and primary cell-based co-culture models, and after 7 days for the human BBB co-culture model. For the permeability experiments inserts were transferred to 12 -well plates containing $1.5 \mathrm{ml}$ Ringer-HEPES buffer supplemented with $1 \% \mathrm{BSA}$ and ITS in the lower/abluminal compartment. To measure the permeability on the BBB models after lidocaine treatment, culture medium in the upper/luminal compartment was replaced with $0.5 \mathrm{ml}$ buffer containing $10 \mu \mathrm{M}$ lidocaine and molecular markers with different surface charges: FITC-dextran $(10 \mu \mathrm{g} / \mathrm{ml}, \mathrm{FD}, \mathrm{Mw}: 10 \mathrm{kDa})$ with neutral charge, positively charged rhodamine $123(10 \mu \mathrm{M}, \mathrm{R} 123, \mathrm{Mw}$ : $380 \mathrm{Da})$ and negatively charged Lucifer yellow ( $5 \mu \mathrm{M}, \mathrm{LY}$, Mw: $457 \mathrm{Da})$. For the cells on culture inserts treated with neuraminidase, in the upper/luminal compartment the serum free medium containing neuraminidase was replaced with $0.5 \mathrm{ml}$ buffer containing FITC-dextran (FD, Mw: 4.4kDa) and Evans blue dye bound to $1 \%$ BSA (EBA, MW: $67.5 \mathrm{kDa}$ ). The cells serving as control were only incubated with the fluorescent markers without any treatment. The plates were kept in a $\mathrm{CO}_{2}$ incubator at $37{ }^{\circ} \mathrm{C}$ on a horizontal shaker $(150 \mathrm{rpm})$ for $30 \mathrm{~min}$ for the lidocaine treatment, and for 1 hour for neuraminidase. After incubation, the samples were collected from the compartments and the concentrations of the marker molecules were determined by a spectrofluorometer (Horiba Jobin Yvon Fluorolog 3, Kyoto, Japan). Excitation/emission values for the different markers were: $440 \mathrm{~nm} / 516 \mathrm{~nm}$ for FD; $498 \mathrm{~nm} / 525 \mathrm{~nm}$ for R123; $420 \mathrm{~nm} / 535 \mathrm{~nm}$ for LY; 582nm/662nm for EBA.

$\mathrm{P}_{\mathrm{e}}$ was calculated as previously described (Nakagawa et al., 2009; Walter et al., 2015a). Briefly, clearance was calculated from the transport of the fluorescent marker molecule from the donor luminal to the acceptor abluminal compartment expressed as $\mu 1$ of donor compartment volume from which the tracer was completely cleared: 


$$
C l=\frac{[C]_{a b} \times V_{a b}}{[C]_{l}}
$$

Where $\mathrm{Cl}$ is the clearance, $[\mathrm{C}]_{\mathrm{ab}}$ and $\mathrm{V}_{\mathrm{ab}}$ represent the concentration and volume $(\mu \mathrm{l})$ of the abluminal compartment, and $[\mathrm{C}]_{1}$ represents the luminal concentration. The average cleared volume was plotted vs. time, and permeability surface area product value for endothelial monolayer $\left(\mathrm{PS}_{\mathrm{e}}\right)$ was calculated by the following formula:

$$
\frac{1}{P S_{\text {endothelial }}}=\frac{1}{P S_{\text {total }}}-\frac{1}{P S_{\text {insert }}}
$$

$\mathrm{PS}_{\mathrm{e}}$ was normalized for the surface area of the cell culture insert $\left(1.12 \mathrm{~cm}^{2}\right)$ and was expressed as $10^{-6} \mathrm{~cm} / \mathrm{s}$. In measurements from the luminal to abluminal (AB) direction the upper compartment served as the donor and the lower compartment as the acceptor. In the case of the abluminal to luminal (BA) direction the donor compartment was the lower, while the acceptor compartment was the upper one.

In order to assess the differences between the integrity of human BBB models kept in static or dynamic conditions in the LOC device the permeability marker molecules LY (Cecchelli et al., 2014) and EBA (Walter et al., 2015a; Veszelka et al., 2018) were used. For the assay, medium in the upper compartments of the LOC devices was replaced with $150 \mu \mathrm{l}$ of Ringer-Hepes solution containing $1 \%$ BSA, $1 \%$ ITS, LY (5 $\mu \mathrm{M})$ and EBA $(165 \mu \mathrm{g} / \mathrm{ml}$ dye bound to $1 \% \mathrm{BSA})$. In the bottom compartments, culture medium was changed to $350 \mu \mathrm{l}$ of Ringer-Hepes solution with $1 \%$ BSA and $1 \%$ ITS. LOCs were incubated in a $\mathrm{CO}_{2}$ incubator at $37{ }^{\circ} \mathrm{C}$ on a horizontal shaker $(150 \mathrm{rpm} / \mathrm{min})$. Samples were collected after 20 and $40 \mathrm{~min}$ from the bottom compartment and at $60 \mathrm{~min}$ from both compartments and fluorescent intensity measured by the spectrofluorometer as described above. The concentrations of each marker were determined by plotting them to a calibration curve. First, the clearance $(\mu \mathrm{l})$ was calculated as described above, and the slope values of the samples $\left(\mathrm{PS}_{\text {total }}\right)$ were used to calculate the apparent permeability coefficient $\left(\mathrm{P}_{\text {app }}\right)$ from the following equation:

$$
P_{a p p}=\frac{P S_{\text {total }}}{A}
$$

where $\mathrm{P}_{\text {app }}$ is the permeability surface area product (clearance rate in $\mu 1 / \mathrm{min}$ ) of the $\mathrm{BBB}$ models on the membranes and $\mathrm{A}$ is the surface area of the membrane $\left(0.8 \mathrm{~cm}^{2}\right)$.

\subsubsection{Measurement of efflux pump activity}

The activity of the P-glycoprotein efflux pump was measured using R123, a substrate of this transporter, as described in the permeability assay section, but both in the $\mathrm{AB}$ and $\mathrm{BA}$ directions. For measurements in the $\mathrm{BA}$ direction the donor compartment 
was the lower, while the acceptor compartment was the upper one. As a reference Pgp pump inhibitor, cyclosporin $\mathrm{A}(10 \mu \mathrm{M})$ was used (30 min pre-treatment of cells). During the assay cells were incubated for 30 min with $10 \mu \mathrm{M}$ R123 with or without $10 \mu \mathrm{M}$ lidocaine in Ringer-HEPES buffer. After the incubation samples were collected from the upper and lower compartments and the concentration of R123 in the samples was determined by the same spectrofluorometer as used in the permeability assays (Horiba Jobin Yvon Fluorolog 3; excitation/emission wavelengths: 498/525 nm).

\subsubsection{Immunocytochemistry for tight junction proteins and image analysis}

After the permeability measurements on the cell culture inserts brain endothelial cells were stained for junctional associated proteins $\beta$-catenin and ZO-1 and for tight junction protein claudin-5 to assess the morphological changes after lidocaine treatment. Cells were fixed with cold acetone-methanol solution (1:1) for 2 min, washed with PBS and non-specific binding sites were blocked with 3\% BSA in PBS for 1 hour at room temperature. Incubation with primary antibodies (dilution 1:200) polyclonal rabbit anti$\beta$-catenin (Sigma C2206), polyclonal rabbit anti-ZO-1 (Invitrogen, 61-7300) and polyclonal rabbit anti-claudin-5 (Sigma, SAB4502981) lasted overnight at $4{ }^{\circ} \mathrm{C}$. The next day cells were incubated with anti-rabbit secondary antibody labelled with Cy3 (Sigma C2306; dilution 1:400), and bis-benzimide H33342 to stain nuclei, for 1 hour at room temperature. Between incubations cells were washed three times with PBS. The stained samples were visualized by a Leica TCS SP5 confocal laser scanning microscope (Leica Microsystems, Germany). Pictures for image analysis (evaluation of the junctional and cytoplasm intensity ratio) were taken with the exact same settings among cell and staining types. The fluorescently labelled images were analyzed using Matlab software (R2019a, MathWorks Inc., USA). First we determined the cytoplasmic intensity, from which binary images (BIs) were created. The complementary BIs were considered as the junctional staining in the plasma membrane. The pixels in the two BIs were used as masks, and the intensities of the original pixels were summed in both the junctional BIs and the cytoplasmic BIs separately. The ratio of the cell membrane and cytoplasm intensities for each image was determined and used for the statistical analysis. The number of images were 11-15 in each group.

To evaluate the morphology of human BLECs kept in static or dynamic condition in the LOC device, the cells were fixed, and membranes washed as described above. The primary antibodies rabbit anti- $\beta$-catenin and rabbit anti-claudin- 5 were used as described above. The same protocol was used to stain bovine brain PCs with primary antibodies mouse anti- $\alpha$-smooth muscle actin (A2547, Sigma, 1:200), rabbit anti-NG2 (AB5320, 
Millipore, Merck, Darmstadt, Germany, 1:200) and rabbit anti-platelet derived growth factor receptor- $\beta$ (ab32570, AbCam, Cambridge, UK, 1:200). Alexa Fluor 488 anti-mouse IgG (A11029, Invitrogen, 1:400), anti-rabbit IgG-CY3 (C2306, Sigma, 1:400) and $\mathrm{H} 33342$ dye $(1 \mu \mathrm{g} / \mathrm{ml})$ were used as secondary antibodies and staining cell nuclei, respectively. Samples were mounted in Fluoromount-G (Southern Biotech, USA) and visualized by a Leica TCS SP5 confocal laser scanning microscope.

\subsection{Staining and visualization of cell surface glycocalyx}

After a 24-hour dynamic or static condition human BLECs after co-culture with PCs were washed with Ringer-Hepes buffer and fixed by $1 \%$ paraformaldehyde in PBS for $15 \mathrm{~min}$ at room temperature. Following fixation cells were washed with PBS twice. Labeling of sialic acid and N-acetyl-D-glucosamine residues within the glycocalyx was done using wheat germ agglutinin (WGA) lectin conjugated with Alexa Fluor 488 (W11261, Invitrogen) diluted at $5 \mu \mathrm{g} / \mathrm{ml}$ concentration in PBS and incubated for $10 \mathrm{~min}$ at room temperature (Betteridge et al., 2017). Pictures were taken with an Olympus FV1000 confocal microscope (Olympus, Japan) at random positions, at least 6 images for each membrane. For each condition three independent experiments were performed. Fluorescent images were analyzed for staining intensity using the FIJI (ImageJ) software. The co-culture of human ECs with brain PCs was performed on the cell culture inserts as described in section 2.4.3. and BLECs were compared to EC mono-cultures.

\subsection{Zeta potential measurements}

The zeta potential $(\zeta)$ was measured by dynamic light scattering using a Zetasizer Nano ZS instrument (Malvern, UK) equipped with a He-Ne laser $(\lambda=632.8 \mathrm{~nm})$. The zeta-potential of the samples was measured at $25^{\circ} \mathrm{C}$, with a minimum of 6 measurements (maximum 100 runs each) and with an applied 20 or $40 \mathrm{~V}$ voltage (Ribeiro et al., 2012). We used disposable zeta potential cuvettes with gold-coated platinum electrodes (DTS1070, Malvern, UK). Before the measurements, the zeta cuvettes were activated with $100 \%$ ethanol or methanol and were rinsed twice with distilled water. After activation, the zeta cuvettes were calibrated with the zeta standard solution (Malvern, UK) as described in the manufacturer's instructions. Cuvettes were always rinsed twice with distilled water between measurements. The hCMEC/D3 and RBEC cells were used for zeta measurements after the cultures reached $90 \%$ confluence. BLECs in static and dynamic conditions were collected after the $7^{\text {th }}$ day in co-culture. Trypsinization of the 
cells was performed very quickly to minimize plasma membrane changes. After trypsinization, $10^{5}$ cells were re-suspended in $1 \mathrm{ml}$ of $\mathrm{PBS}$ with $\mathrm{Ca}^{2+}$ and $\mathrm{Mg}^{2+}$. Aliquots of cells in suspension were treated with different concentrations of lidocaine $(10,100$ and $1000 \mu \mathrm{M}$ ) for $30 \mathrm{~min}$ at $37^{\circ} \mathrm{C}$, or with neuraminidase for $1 \mathrm{~h}$ at $37^{\circ} \mathrm{C}$ before the measurement. The Zetasizer Software v.7.12. calculated the zeta potential values using the Smoluchowski equation (Domingues et al., 2008):

$$
\zeta=\frac{4 \pi \mu \eta}{\varepsilon}
$$

where $\mu$ represents the electrophoretic mobility, $\eta$ the viscosity of the solvent and $\varepsilon$ the dielectric constant.

\subsection{Gene sequencing}

\subsubsection{Total RNA isolation}

After 24-hour static or dynamic conditions in the LOC device, human BLECs were removed from the LOC devices by a fast and gentle trypsinization and RNA was isolated using the RNeasy Plus Micro Kit (Qiagen, Hilden, Germany) following the manufacturer's instructions. The kit contained an integrated gDNA eliminator spin column, which allows DNA depletion from our RNA samples. RNA integrity was analyzed using automated capillary electrophoresis (RNA Pico Sensitivity Assay, LabChip GX II Touch HT, Perkin Elmer, USA). RNA samples were stored at $-80{ }^{\circ} \mathrm{C}$ until further analysis.

\subsubsection{Massive analysis of cDNA ends library preparation and RNA sequencing}

Samples with $100 \mathrm{ng}$ of purified RNA were used for library preparation. RNA was fragmented using GenXPro (Germany) Fragmentation Buffer. Synthesis of cDNA was performed by reverse transcription using barcoded oligo(dT) primers containing TrueQuant unique molecular identifiers, followed by template switching. Library amplification was done using polymerase chain reaction (PCR), purified by solid phase reversible immobilization beads (Agencourt AMPure XP, Beckman Coulter, USA) and subsequent sequencing was performed using a NextSeq platform (Illumina Inc., USA). Genome-wide gene expression profiling was performed using massive analysis of cDNA ends (MACE-seq) with RNA extracted from BLECs (co-cultured with PCs) in static and dynamic conditions ( 3 and 5 biological replicates, respectively). A total of 8 libraries were constructed using the Rapid MACE-Seq kit (GenXPro GmbH, Germany), according to the manufacturer's protocol. MACE-seq performs gene expression profiling by 
sequencing part of the 3' end of mRNA transcripts. While synthetizing one cDNA molecule from each mRNA transcript, MACE-seq can accurately quantify transcribed polyadenylated transcripts.

\subsubsection{Bioinformatic analysis of MACE-seq data}

Approximately 62 million MACE-seq reads were obtained across all 8 libraries, and subsequently processed and analyzed using bioinformatic tools. PCR-duplicates were identified using the TrueQuant technology and subsequently removed from the raw data. The remaining reads were further poly(A)-trimmed and low-quality reads were discarded. In the following step, the clean reads were aligned to the human reference genome (hg38, http://genome.ucsc.edu/cgi-bin/hgTables) using bowtie2 mapping tool resulting in a dataset of 28,834 different genes. The gene count data was normalized to account for differences in library size and RNA composition bias by calculating the median of gene expression ratios using DESeq2 R/Bioconductor package (Love et al., 2014).Testing for differential gene expression was also performed using the DESeq2 R/Bioconductor package. As a result, $\mathrm{p}$-value and $\log 2$ (fold change) (log2FC) were obtained for each gene in the dataset. False discovery rate analysis was estimated to account for multiple testing. Genes with a p-value $<0.05$ and $|\log 2 \mathrm{FC}|>1$ were differentially expressed. To perform functional profiling analysis g: Profiler was used to identify over-represented biochemical pathways from 3 databases (KEGG, Reactome and Gene Ontology) and to calculate the statistical significance of each pathway. GOplot was used to calculate the z-score from each over-represented pathway (Walter et al., 2015b). The transcriptomic datasets generated and analyzed in this study are available in the Gene Expression Omnibus (GEO) repository (Edgar et al., 2002). GEO accession number is GSE155671 and will also be available at the BBBHub (http://bbbhub.unibe.ch).

\subsection{Statistics}

Data are represented as means $\pm \mathrm{SD}$. To test the statistical significance between different groups, data were analyzed with unpaired t-test, one-way ANOVA or two-way ANOVA followed by Dunnett or Bonferroni multiple comparison post-tests (GraphPad Prism 5.0; GraphPad Software, USA). All experiments were repeated at least twice, and the number of parallel samples was at minimum three. Changes were considered statistically significant at $\mathrm{p}<0.05$. 


\section{Results}

\subsection{Characterization of the different blood-brain barrier models}

Three BBB models were used to study barrier integrity and brain endothelial surface: the immortalized cell line hCMEC/D3 and two co-culture models, one based on rat primary cells and another derived from human stem cells. These three models were investigated on both cell culture inserts and in the LOC microfluidic device. Understanding how the models behave in each setup is important to further investigate the glycocalyx and surface charge using these in vitro BBB models. The integrity of the barrier in the different BBB models was determined by TEER measurement, a commonly used method to assess the tightness of the barrier, followed by barrier permeability for different molecular weight fluorescent marker molecules. After these assays, immunocytochemistry for junctional proteins and staining for surface glycocalyx was performed to characterize the models in the different setups. As shown in Figure 10A, the primary rat cell based co-culture model (RBEC co-cultured with rat PC and astrocytes) cultured on the cell culture inserts has TEER values 2.5 -fold higher $\left(241.0 \pm 5.6 \Omega \times \mathrm{cm}^{2}\right)$ compared to the TEER of the hCMEC/D3 cell line $\left(86.1 \pm 8.5 \Omega \times \mathrm{cm}^{2}\right)$, and seven times higher compared to that of human BLEC and bovine pericyte co-culture model (BLEC: $35.6 \pm 14.5 \Omega \times \mathrm{cm}^{2}$ ). This indicates a tighter barrier for the primary co-culture model, compared with that of the human cell line or the human co-culture model. Similar observations were made for the permeability measurements (Figure 10B). We measured a 13-fold less permeability for LY marker in the RBEC co-culture model $\left(3.2 \pm 0.4 \times 10^{-}\right.$ $\left.{ }^{6} \mathrm{~cm} / \mathrm{s}\right)$ as compared to the hCMEC/D3 cell line $\left(41.2 \pm 12.9 \times 10^{-6} \mathrm{~cm} / \mathrm{s}\right)$. An eight-fold difference was also observed compared to the human stem cell model (BLEC: $24.0 \pm 3.4 \times 10^{-6} \mathrm{~cm} / \mathrm{s}$ ). The permeability for LY of human ECs cultured alone was 10fold higher (hEC: $32.1 \pm 3.1 \times 10^{-6} \mathrm{~cm} / \mathrm{s}$ ) than that of the rat BBB model. The differences in the permeability values indicate a stronger barrier in the primary co-culture model.

When the different BBB models were cultured on the LOC device, the human BLEC co-culture BBB model (Figure 10C) had a higher TEER $\left(334.3 \pm 16.7 \Omega \times \mathrm{cm}^{2}\right)$ compared to those measured in cell culture insert. Similar TEER was observed for the primary rat co-culture model $\left(103.3 \pm 7.6 \Omega \times \mathrm{cm}^{2}\right)$ and the human mono-culture model (hEC: $115.0 \pm 24.7 \Omega \times \mathrm{cm}^{2}$ ). The human cell line had a lower TEER compared with the other models (19.0 $\left.\pm 2.8 \Omega \times \mathrm{cm}^{2}\right)$, similarly to cell culture insert data. 


\section{Cell culture inserts}

A

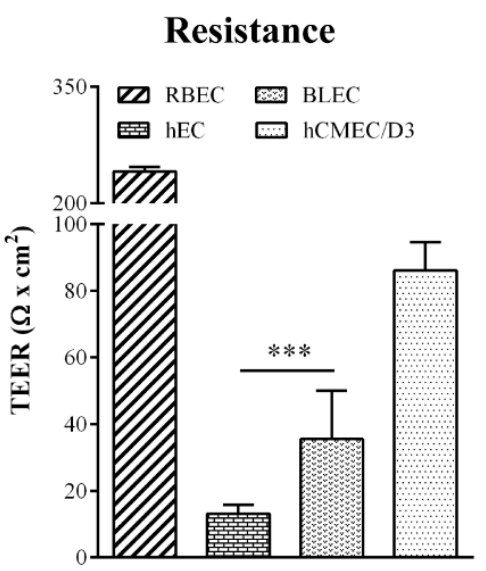

B

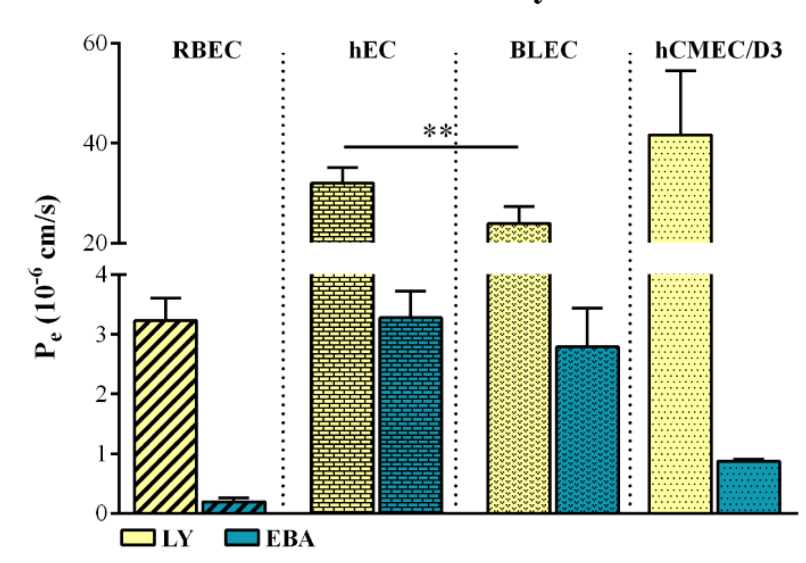

\section{LOC device}

C

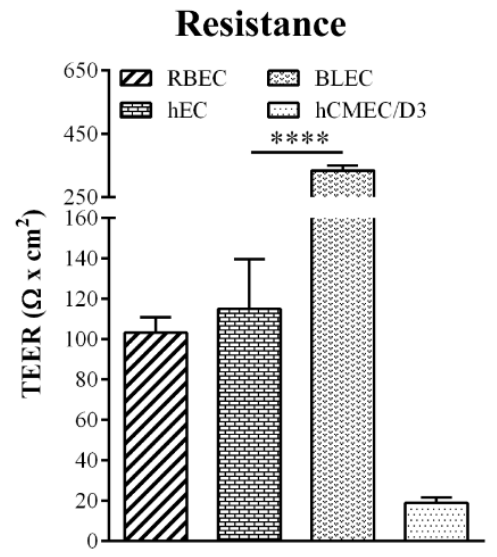

D

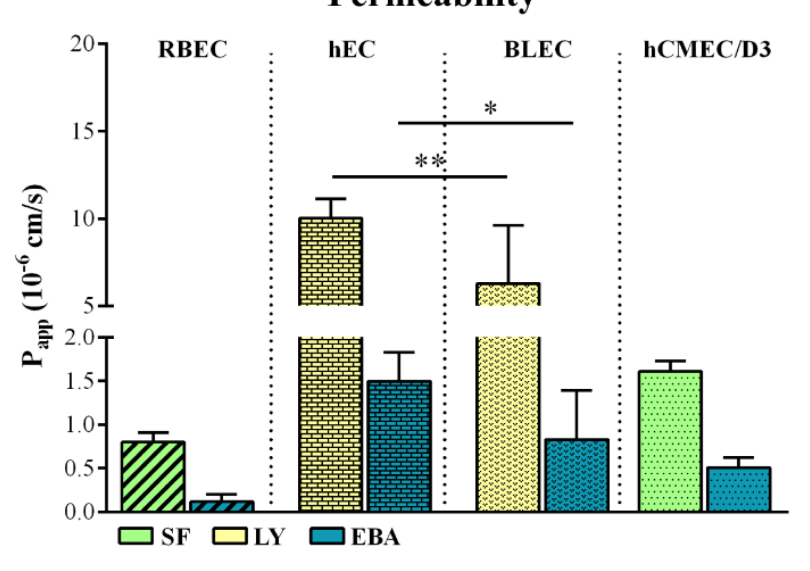

Figure 10. Evaluation of the integrity of the blood-brain barrier (BBB) models kept on cell culture inserts (A-B) or on lab-on-a-chip microfluidic device (C-D). The following BBB models were used: hCMEC/D3 human brain endothelial cell line, a primary cell-based model consisting of rat brain endothelial cells (RBEC) co-cultured with rat pericytes and rat astroglia, human endothelial cells (hEC) in mono-culture, and brain like endothelial cells (BLEC) in co-culture with bovine brain pericytes. (A) Transendothelial electrical resistance (TEER) measurement on the BBB models cultured on cell culture inserts $(n=3-12)$. (B) Endothelial permeability coefficients $\left(P_{e}\right)$ of BBB models for Lucifer yellow (LY) and Evans-blue labeled albumin (EBA) (n=3). (C) TEER values of the BBB models cultured in the lab-on-a-chip device $(n=3)$. (D) Apparent permeability coefficient $\left(\mathrm{P}_{\text {app }}\right)$ of the BBB models for LY, EBA, and sodium fluorescein (SF) tracers $(\mathrm{n}=3-10)$. Values are presented as mean $\pm \mathrm{SD}$ on all graphs, ${ }^{*} \mathrm{p}<0.05,{ }^{*} \mathrm{p}<0.01, * * * \mathrm{p}<0.001, \mathrm{P}<0.0001$ compared to the hEC group.

The permeability values were lower for all the BBB models in the LOC device than on the cell culture inserts (Figure 10D). The $\mathrm{P}_{\text {app }}$ for fluorescein of the primary coculture and the human cell line models was $0.8 \pm 0.1 \times 10^{-6}$ and $1.6 \pm 0.1 \times 10^{-6} \mathrm{~cm} / \mathrm{s}$, respectively. An even lower permeability was observed for albumin in both models. The human EC mono- and co-culture models showed several fold higher permeability for LY, 
$10.0 \pm 1.1 \times 10^{-6}$ and $6.3 \pm 1.3 \times 10^{-6} \mathrm{~cm} / \mathrm{s}$, respectively. Approximately 10 -fold less $\mathrm{P}_{\text {app }}$ was measured for albumin on these models. These data are in accordance with previous results obtained on the same BBB models in cell culture inserts (Veszelka et al., 2018; Heymans et al., 2020) and on the LOC (Walter et al., 2016).

A

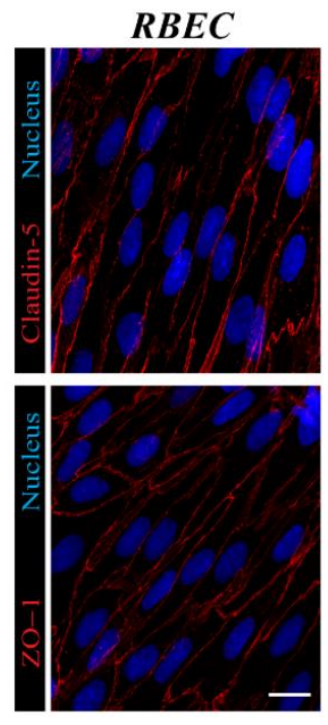

B

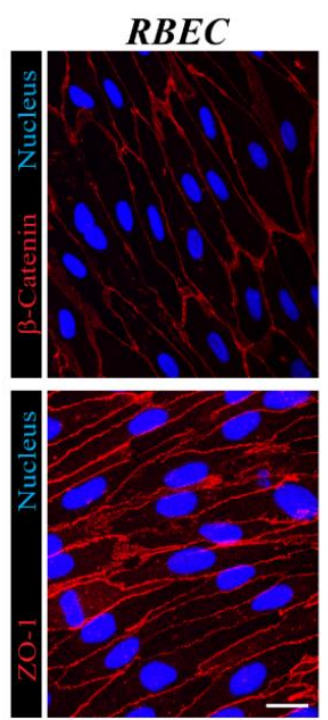

\section{Cell culture inserts}
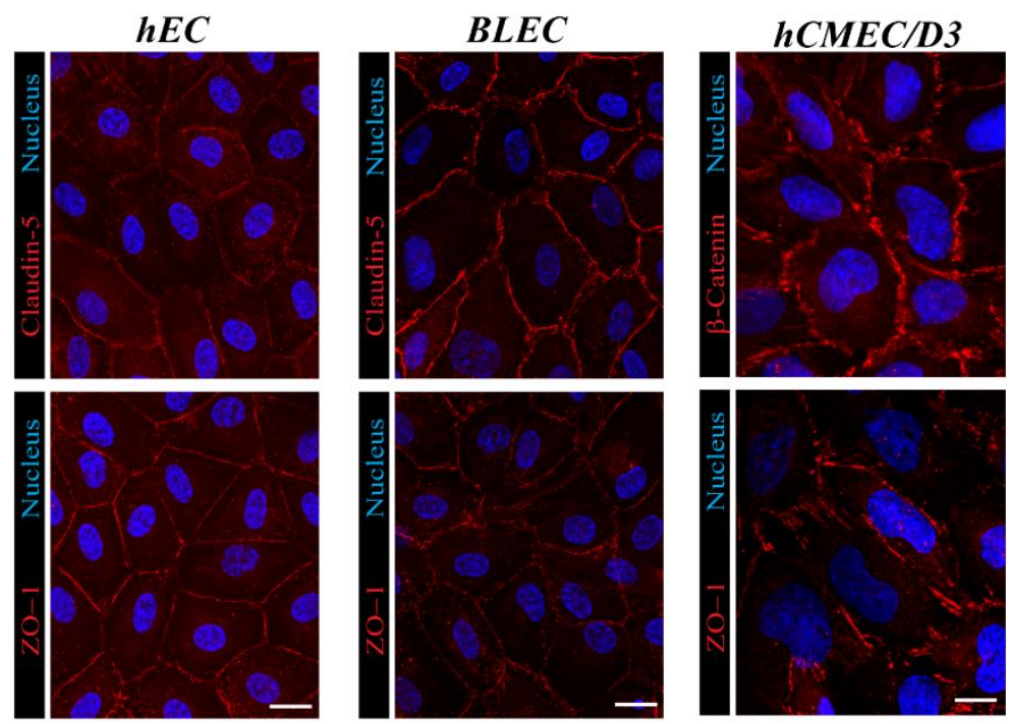

\section{LOC device}
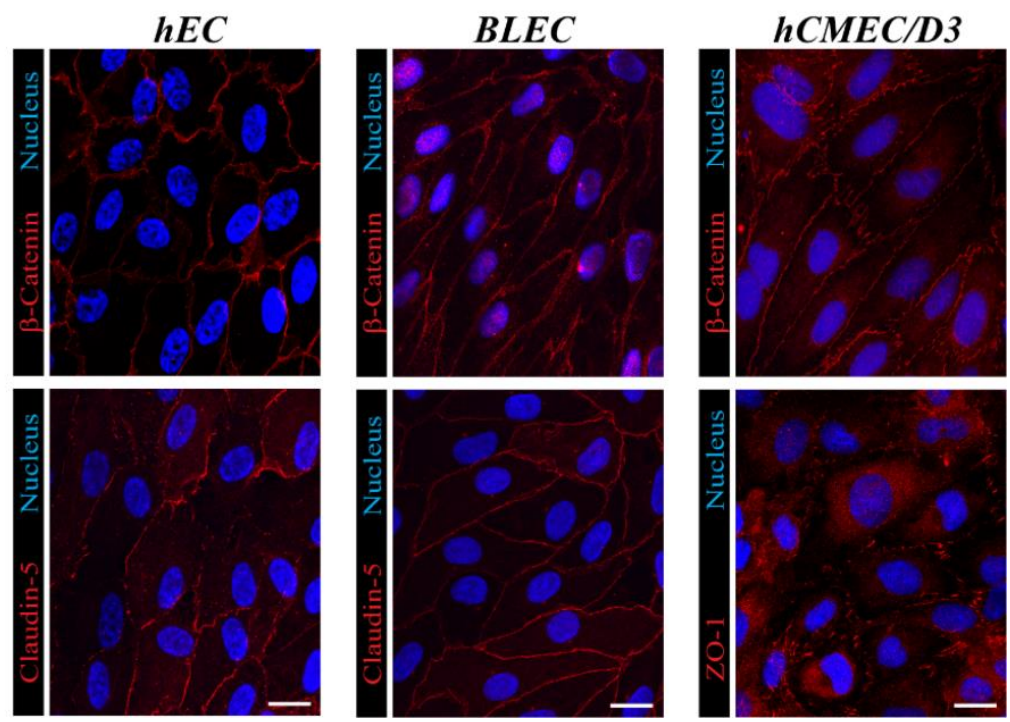

Figure 11. Brain endothelial cell morphology was characterized by immunohistochemistry for junctional proteins $\beta$-catenin, claudin-5 and ZO-1. (A) BBB models cultured on cell culture inserts. (B) BBB models cultured in the lab-on-a-chip (LOC) device. Red: immunostaining for junctional proteins. Blue: cell nuclei. Scale bar: $20 \mu \mathrm{m}$. RBEC: rat brain endothelial cells cocultured with rat pericytes and rat astroglia; hEC: human endothelial cells in mono-culture; BLEC: brain like endothelial cells co-cultured with bovine brain pericytes; hCMEC/D3 human brain endothelial cell line; hCMEC/D3: human brain endothelial cell line. (stainings of RBEC and hCMEC/D3 models in the LOC device were published in Walter et al., 2016). 
To further characterize the BBB models in the different cell culture setups, immunostaining for junctional associated proteins $\beta$-catenin and ZO-1, and tight junction protein claudin-5 was performed. As demonstrated in Figure 11 the junctional proteins were present in all BBB models both in the cell culture insert and the LOC device. The morphology of the brain endothelial cells reflected well their barrier integrity measured by resistance and permeability tests. In the rat co-culture model, the tightest from the different BBB models, the immunostaining pattern was strong and continuous at the cell borders. The leakiest barrier, the cell line model showed the least organized and uniform staining at cell-cell junctions. The overall morphology of the cells was similar in the two setups.

The endothelial glycocalyx forms a continuous sugar coat on the surface of the cells and plays an important role in the barrier function. It acts as a physical barrier for charged molecule or drug permeability. The morphology of the brain endothelial cell surface glycocalyx from the different BBB models, cultured either on the cell culture inserts or on the LOC device is shown in Figure 12.

\section{Cell culture inserts}

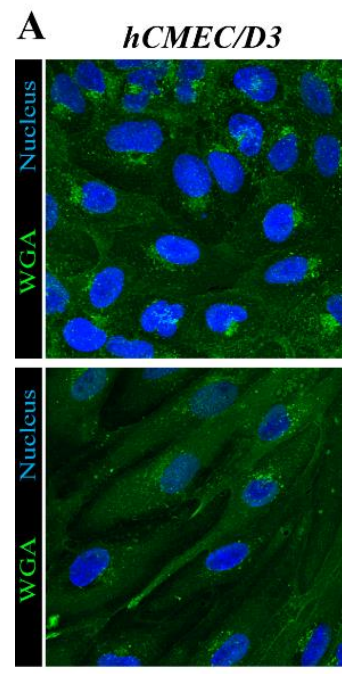

RBEC

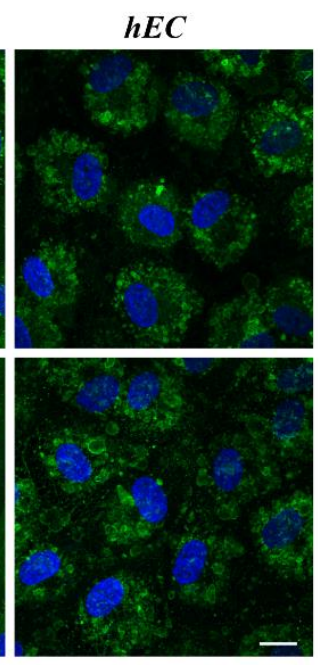

$B L E C$

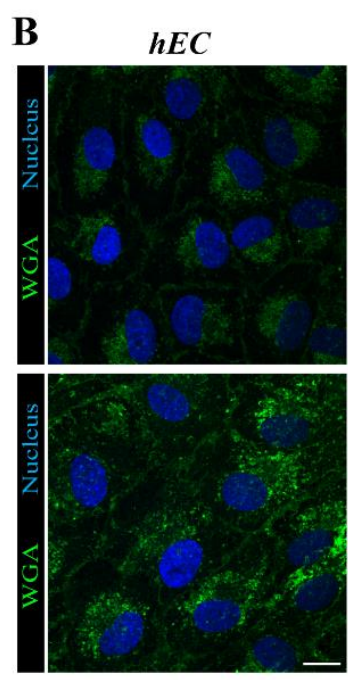

BLEC
LOC device

C

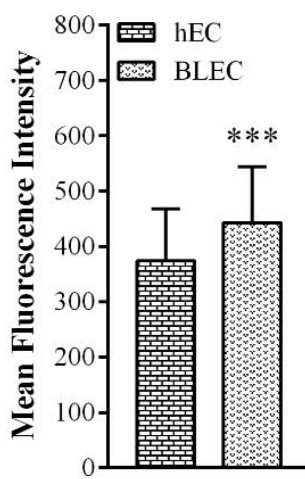

Figure 12. Staining of the cell surface glycocalyx of brain endothelial cells with fluorescently labeled wheat germ agglutinin lectin. (A) Blood-brain barrier (BBB) models cultured on the cell culture inserts. (B) Models cultured on the lab-on-a-chip device. Green: glycocalyx staining. Blue: cell nuclei. Scale bar: $20 \mu \mathrm{m}$. (C) Analysis of the fluorescent intensity of WGA stainings. RBEC: rat brain endothelial cells co-cultured with rat pericytes and rat astroglia; hEC: human endothelial cells in mono-culture; BLEC: brain like endothelial cells co-cultured with bovine brain pericytes; hCMEC/D3 human brain endothelial cell line.

On the cell culture inserts the surface glycocalyx was visible in all the BBB models and showed an inhomogeneous pattern with higher intensity around the cell nuclei 
(Figure 12A). We investigated in the LOC device for the first time the effect of co-culture on the glycocalyx using the human BBB model. A stronger staining was found in this setup for the co-culture model (BLEC) compared to the monoculture (hEC) (Figure 12B and C).

\subsection{Modulation of the brain endothelial glycocalyx and surface charge using the neuraminidase enzyme}

\subsubsection{Effect of neuraminidase on the cell viability of primary brain endothelial cells}

First, to exclude any toxic effect, the metabolic activity of rat primary brain endothelial cells was determined after neuraminidase treatment. We found no change in the metabolic activity of RBECs following neuraminidase treatment in the $0.01-1 \mathrm{U} / \mathrm{ml}$ concentration range for 1 hour as compared to the control group (Figure 13). Triton X100 detergent was used to cause immediate toxic effect (cell lysis). We observed that none of the enzyme concentrations exerted cell damage. Therefore, the concentration range of $0.1-1 \mathrm{U} / \mathrm{ml}$ was used for the further experiments.

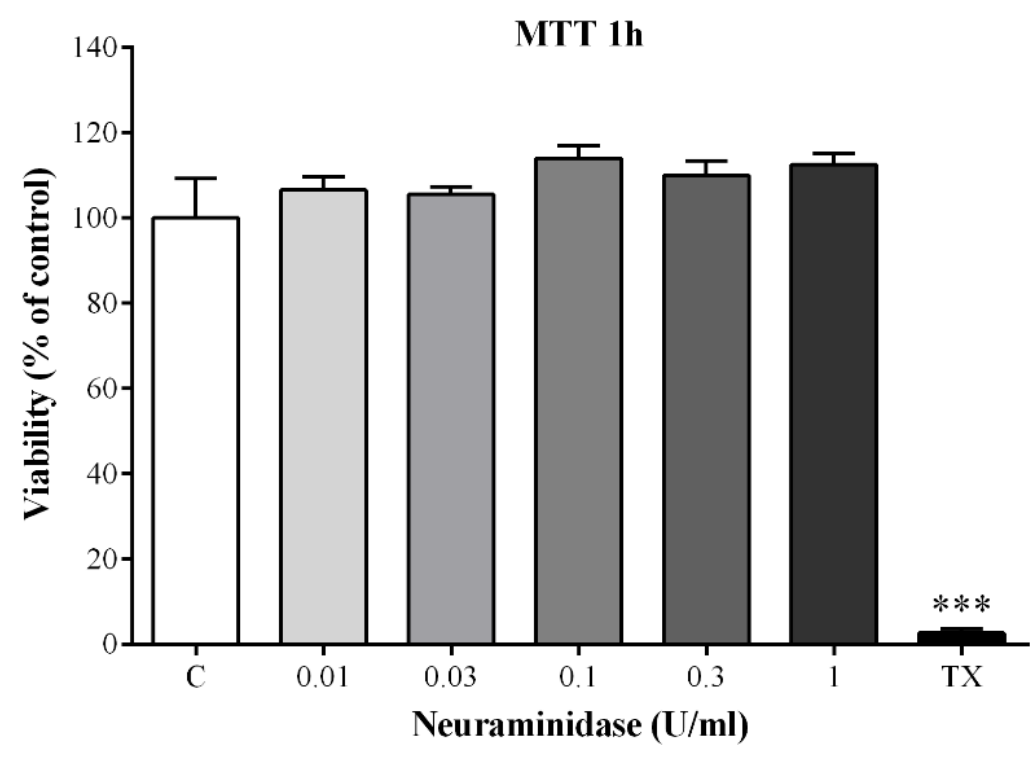

Figure 13. The effect of neuraminidase treatment on MTT dye conversion reflecting the metabolic activity in rat primary brain endothelial cells. Treatment with neuraminidase was performed in the 0.01-1 U/ml concentration range for 1 hour $(n=8)$. Values of each group are presented as mean \pm SD. One-way ANOVA followed by Dunnett test. $* * \mathrm{p}<0.01, * * * \mathrm{p}<0.001$. 


\subsubsection{Neuraminidase as a modulator of the glycocalyx and surface charge of brain}

\section{endothelial cells}

The surface glycocalyx of brain endothelial cells can be modified by enzymatic digestion. Neuraminidase, a glycoside-hydrolase enzyme, cleaves sialic acid residues, which was visualized by the sialic acid specific lectin WGA-Alexa 488 staining, followed by confocal microscopy and image analysis for staining intensity (Figure 14).

A
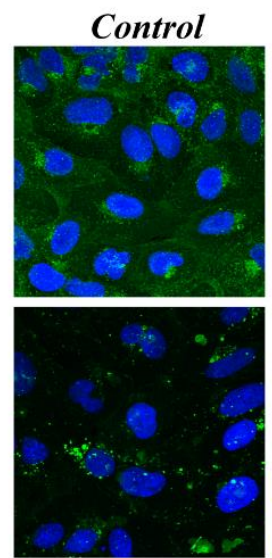

$0.3 \mathrm{U} / \mathrm{ml}$

C
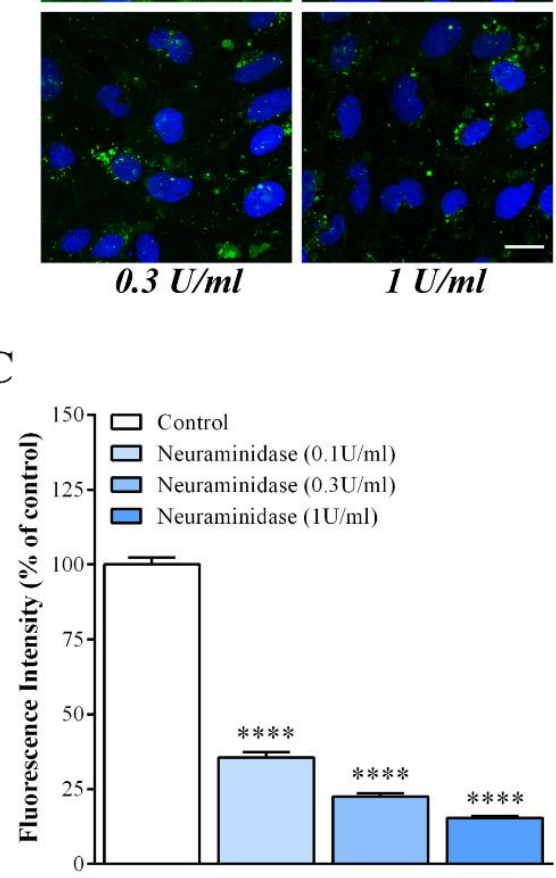

B
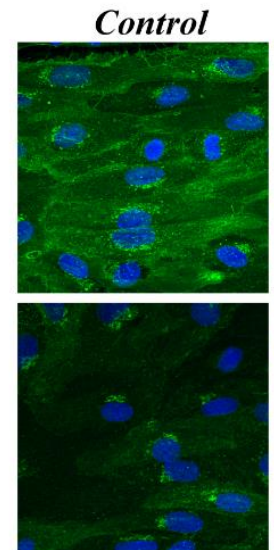

$0.3 \mathrm{U} / \mathrm{ml}$

D

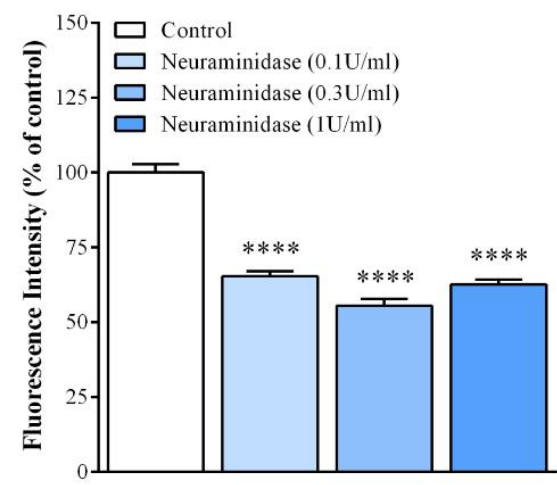

Figure 14. The effect of neuraminidase $(0.1,0.3$ and $1 \mathrm{U} / \mathrm{ml})$ on hCMEC/D3 human brain endothelial cells and rat primary brain endothelial cells (RBEC). (A and B) Representative pictures of the staining with wheat germ agglutinin (WGA) lectin labeled with Alexa 488 with or without neuraminidase treatment. Scale bar: $20 \mu \mathrm{m}$. (C and D) Image analysis of the fluorescent intensity of the lectin labeling on pictures taken by confocal microscopy $(n=16-32)$. Values are presented as means \pm SD. One-way ANOVA and Bonferroni post-test. $* * * * p<0.0001$, compared to control.

Neuraminidase at $1 \mathrm{U} / \mathrm{ml}$ concentration reduced the labeling by $80 \%$ on the surface of hCMEC/D3 cells and by $40 \%$ on the surface of RBECs. A concentration dependent effect of the enzyme on lectin staining was observed in hCMEC/D3 cells when 
treated with $0.1 \mathrm{U} / \mathrm{ml}$ and $0.3 \mathrm{U} / \mathrm{m}$ neuraminidase (Figure $14 \mathrm{C}$ ), but not in RBECs, in which the effects were more similar (Figure 14D).

We hypothesized, that neuraminidase by cleaving sialic acid residues reduces the amount of negative charge on the glycocalyx, and consequently, turns it more positive. In a recent paper the surface charge of brain endothelial cells was measured by laser-Doppler velocimetry (Ribeiro et al., 2012) and the technique was adapted in our group. We determined with zeta potential measurements the effect of 1-hour neuraminidase treatment (0.1-1 U/ml) on hCMEC/D3 and RBEC cells.

\section{hCMEC/D3}

A

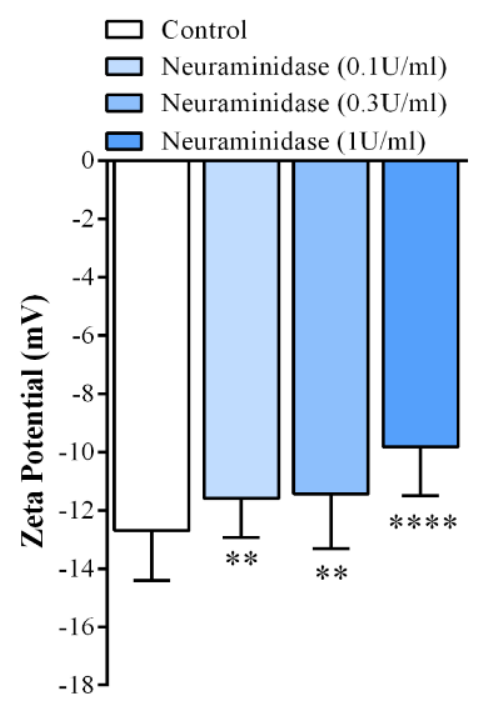

RBEC

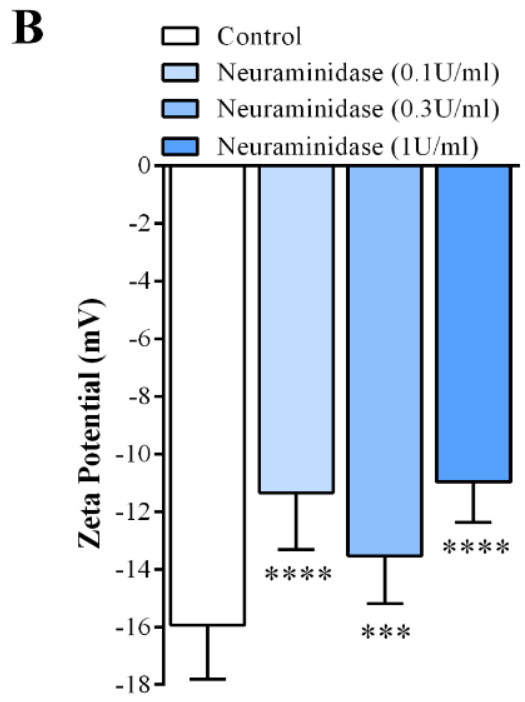

Figure 15. The effect of neuraminidase $(0.1,0.3$ and $1 \mathrm{U} / \mathrm{ml})$ on hCMEC/D3 human brain endothelial cells and RBEC rat primary brain endothelial cells. (A and B) Effect of different concentrations of neuraminidase on the surface charge of cells measured by laser-Doppler velocimetry $(n=30-66)$. Values of each group are presented as mean \pm SD. One-way ANOVA and Bonferroni post-test. $* * \mathrm{p}<0.01, * * * \mathrm{p}<0.001, * * * * \mathrm{p}<0.0001$ compared to the control group.

As shown in Figure 15A, neuraminidase treatment at $0.1,0.3$ and $1 \mathrm{U} / \mathrm{ml}$ concentrations significantly increased the surface charge of hCMEC from $-12.7 \pm 1.7 \mathrm{mV}$ measured under control conditions to $-11.6 \pm 1.3,-11.4 \pm 1.9$, and $-9.8 \pm 1.7 \mathrm{mV}$, respectively. Similar results were obtained for the RBECs (Figure 15B), where the neuraminidase treatment at $0.1,0.3$ and $1 \mathrm{U} / \mathrm{ml}$ concentrations increased the surface charge to $-11.4 \pm 2.0,-13.5 \pm 1.7,-10.9 \pm 1.4 \mathrm{mV}$, respectively, compared with the zeta potential value of the control group $(-16.0 \pm 1.9 \mathrm{Mv})$ which did not receive any treatment. 


\subsubsection{Integrity of the BBB models after neuraminidase treatment}

The TEER of the BBB models cultured in cell culture inserts was measured. Since no toxicity for neuraminidase was observed for the different concentrations (Figure 13), and $1 \mathrm{U} / \mathrm{ml}$ was the most effective concentration in cleaving off the sialic acids from the glycocalyx (Figure 14-15), the barrier integrity was tested in the two BBB models (hCMEC/D3 and RBEC) at the highest concentration of neuraminidase.

\section{hCMEC/D3}

A

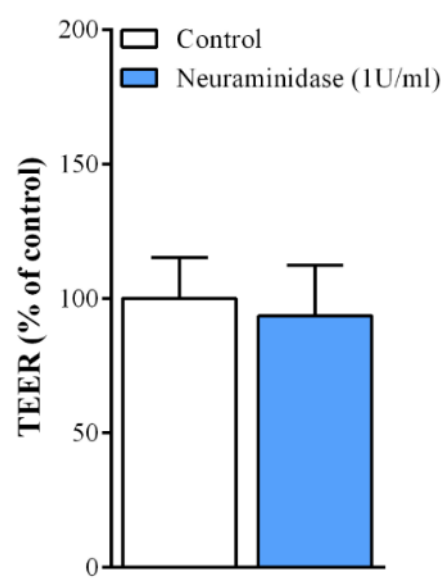

C

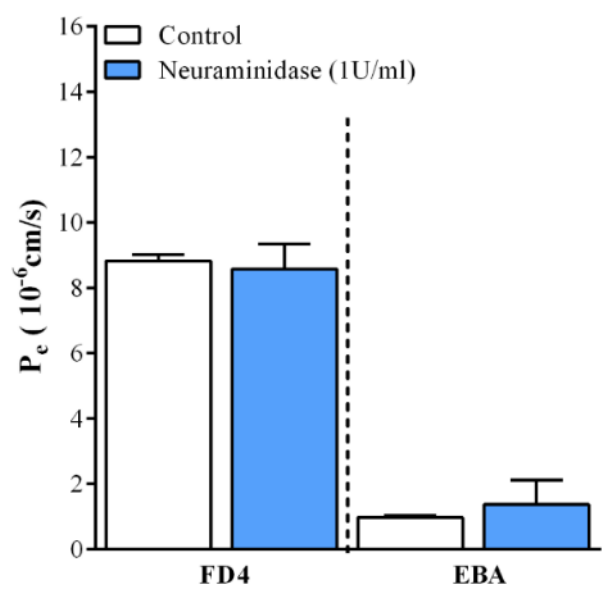

RBEC

B

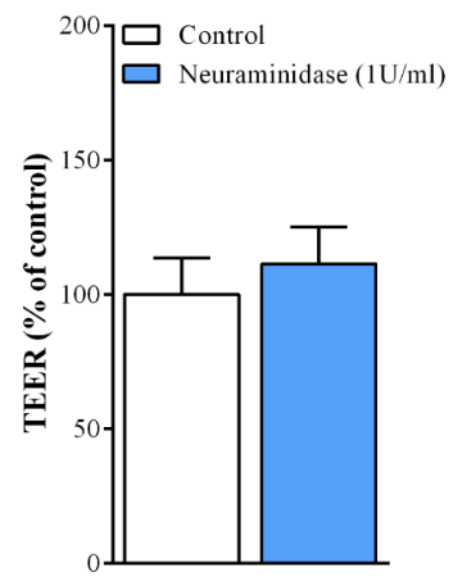

D

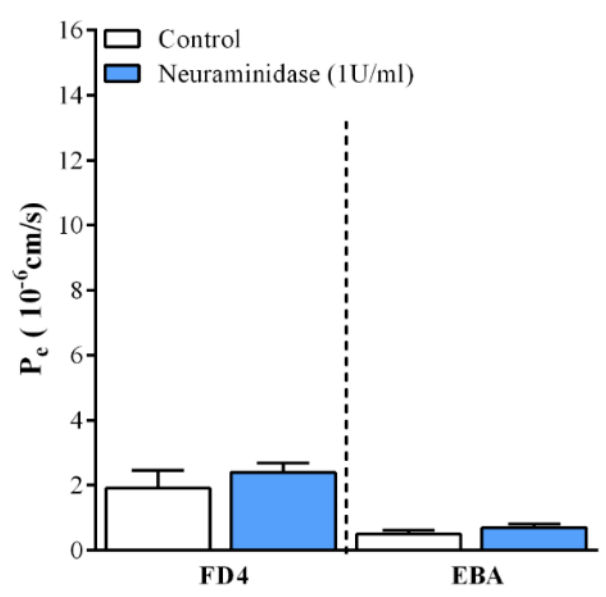

Figure 16. Evaluation of the barrier integrity of hCMEC/D3 human brain endothelial cell layers $(\mathrm{A}, \mathrm{C})$ and rat primary brain endothelial cells (RBEC) co-cultured with pericytes and astrocytes $(B, D)$ on cell culture inserts. (A-B) Transendothelial electrical resistance (TEER) measurements after 1-hour neuraminidase treatment $(n=3)$. (C-D) Endothelial permeability coefficient $\left(\mathrm{P}_{\mathrm{e}}\right)$ of cells treated with neuraminidase for two hydrophilic tracers, $4 \mathrm{kDa}$ FITC-dextran (FD4) and albumin $(E B A)(n=3)$. Values are presented as means $\pm S D$. Data were analyzed by unpaired $t-$ test, no statistically significant difference was observed. 
The resistance of the brain endothelial cell cultures did not change after treatments (Figure 16A-B). The TEER of the control group was $15.3 \pm 4.0 \Omega \times \mathrm{cm}^{2}$ in hCMEC/D3 cells and it remained unchanged after neuraminidase treatment $\left(14.3 \pm 5.0 \Omega \times \mathrm{cm}^{2}\right)$. In case of RBECs we measured $150.0 \pm 35.6 \Omega \times \mathrm{cm}^{2}$ for the control group and a similar value $\left(164.3 \pm 35.5 \Omega \times \mathrm{cm}^{2}\right)$ was observed after the treatment. Regarding the permeability of the BBB models for dextran and albumin, no significant change was observed between the control and neuraminidase treatment groups. The permeability for dextran (FD4) of hCMEC/D3 cells was $8.8 \pm 0.2 \times 10^{-6} \mathrm{~cm} / \mathrm{s}$ and $8.6 \pm 0.8 \times 10^{-6} \mathrm{~cm} / \mathrm{s}$ without and with neuraminidase treatment, respectively (Figure 16C). A four-fold difference was observed between the FD4 permeability of the hCMEC/D3 and the RBEC models. The RBEC showed $1.9 \pm 0.3 \times 10^{-6} \mathrm{~cm} / \mathrm{s} \mathrm{P}_{\mathrm{e}}$ for FD4, and a similar value was measured $\left(2.4 \pm 0.3 \times 10^{-6} \mathrm{~cm} / \mathrm{s}\right)$ after neuraminidase treatment (Figure 16D). In accordance with results shown in section 3.1., there was a lower permeability for albumin in both models: $0.9 \pm 0.1 \times 10^{-6} \mathrm{~cm} / \mathrm{s}$ for hCMEC/D3 and $0.5 \pm 0.1 \times 10^{-6} \mathrm{~cm} / \mathrm{s}$ for RBEC under control conditions. No significant change was observed after neuraminidase treatment.

\subsection{Modulation of the brain endothelial surface charge by lidocaine}

\subsubsection{Effect of lidocaine on brain endothelial cell viability}

First, the effects of lidocaine on the viability, metabolic activity and membrane integrity were studied using the hCMEC/D3 cell line and primary RBECs. Lidocaine at 1-300 $\mu \mathrm{M}$ concentrations did not cause any drop in the cell impedance after $30 \mathrm{~min}$ (Figure 17 A-B). Incubation of the cell monolayers for $30 \mathrm{~min}$ with lidocaine (concentration range of $1-1000 \mu \mathrm{M}$ ) by the MTT conversion assay, did not cause any alteration in the metabolic activity of the cells (Figure 17C-D).

To determine if lidocaine damages the plasma membrane LDH assay was performed. As shown in Figure $17 \mathrm{E}-\mathrm{F}$, the release of LDH from the brain endothelial cells did not increase compared to the control group indicating an unchanged membrane integrity. Triton X-100 detergent was used as a reference compound to exert toxicity in all these assays (Figure 17). 
hCMEC/D3

A

Impedance $30 \mathrm{~min}$

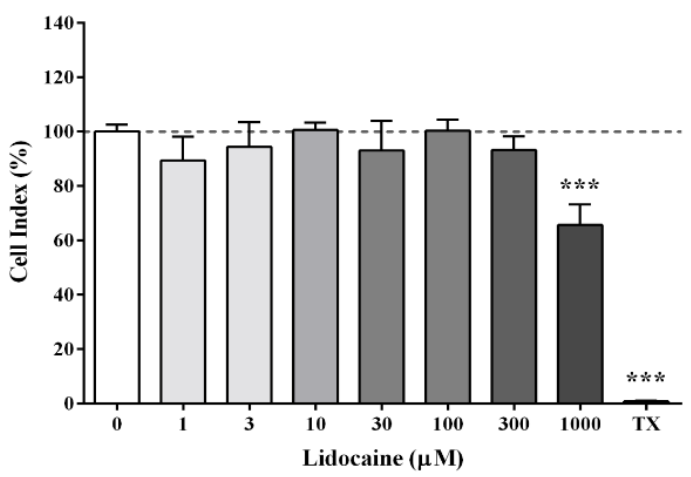

C

MTT $30 \mathrm{~min}$

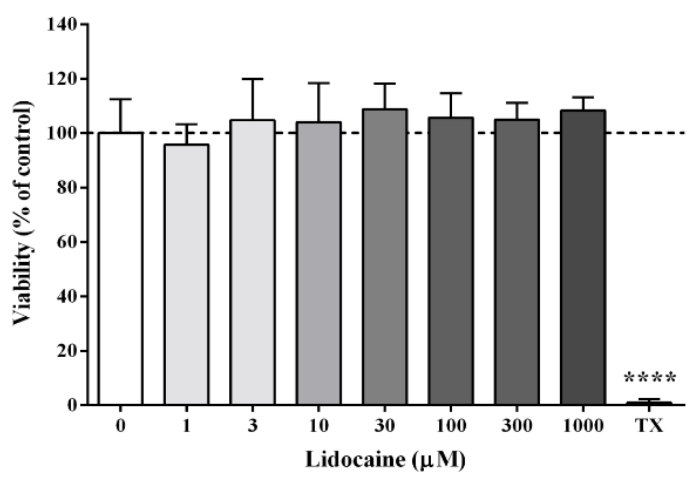

$\mathbf{E}$

LDH $30 \mathrm{~min}$

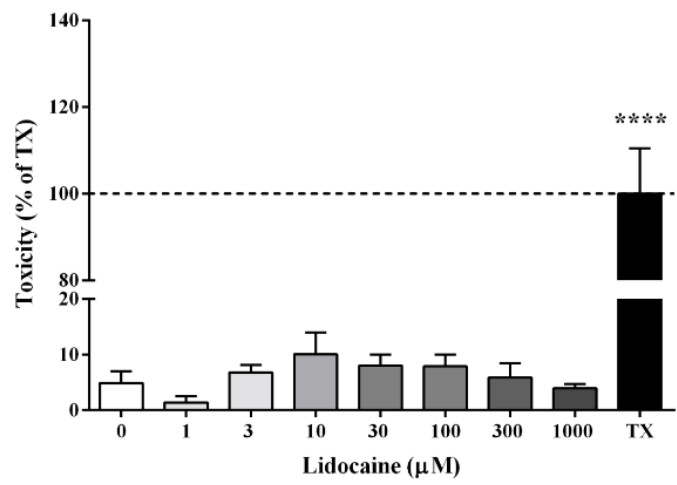

RBEC

B

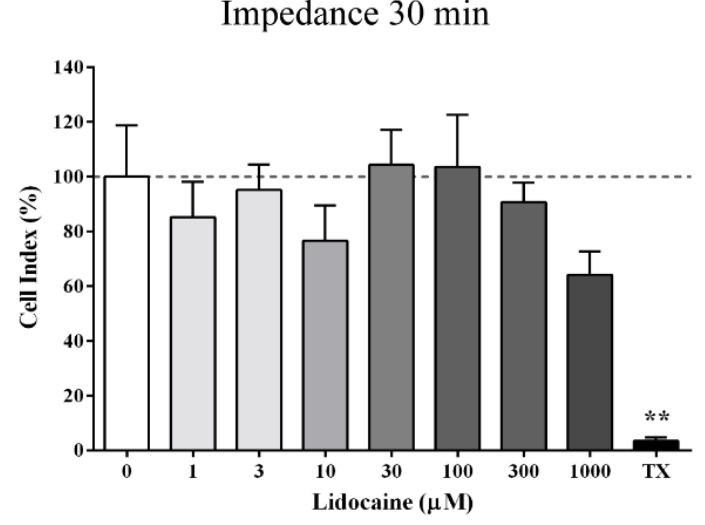

D

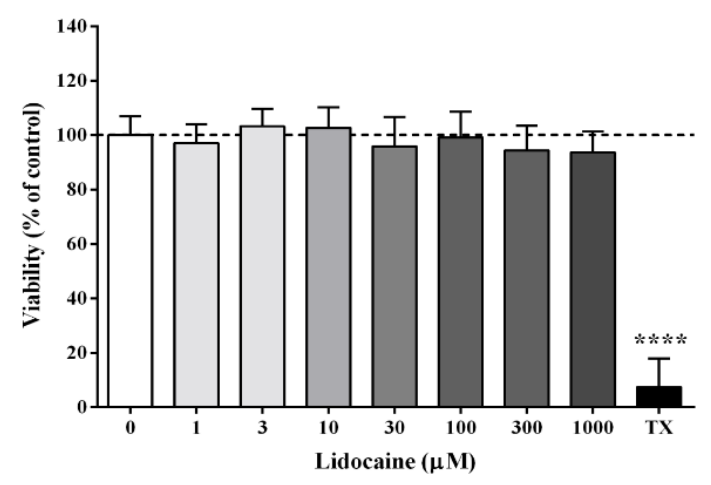

F

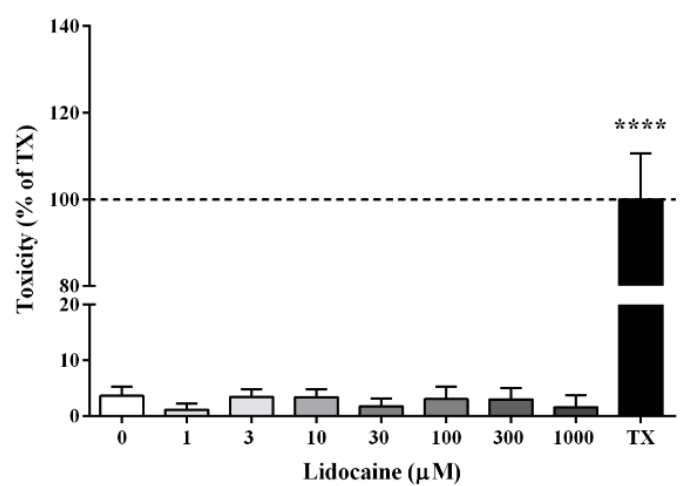

Figure 17. Cell viability assays showing the effects of lidocaine on brain endothelial cells. Treatments were performed for $30 \mathrm{~min}$ with concentrations of 1-1000 $\mu \mathrm{M}$. (A-B): Impedance measurements on hCMEC/D3 human brain endothelial cell line and on primary rat brain endothelial cells (RBEC) ( $n=6-8)$. (C-D): The effects of lidocaine on MTT dye conversion reflecting metabolic activity ( $\mathrm{n}=6-8)$. (E-F): Lactate dehydrogenase (LDH) release after lidocaine treatment reflecting membrane integrity $(n=6-8)$. Values of each group are presented as mean \pm SD. Data were analyzed by one-way ANOVA followed by Bonferroni post-test. *** $\mathrm{p}<0.001$, $* * * * \mathrm{p}<0.0001$ compared to the untreated control group. TX: Triton X-100 detergent, a reference agent causing toxicity. 


\subsubsection{Lidocaine as a modulator of the surface charge of brain endothelial cells}

We hypothesized that the cationic and lipophilic lidocaine could change the surface charge of brain endothelial cell membranes, because it can intercalate into the plasma membrane. To prove this hypothesis, we directly measured the effects of lidocaine on the zeta potential of two types of brain endothelial cells. In these experiments single cell suspensions of untreated hCMEC/D3 human brain endothelial cells and primary RBECs, or cells treated with 10,100 and $1000 \mu \mathrm{M}$ lidocaine were used. The base zeta potential for the two BBB models were negative: $-11.4 \pm 1.3 \mathrm{mV}$ for the hCMEC/D3 cells (Figure 18A) and $-12.3 \pm 1.2 \mathrm{mV}$ for the RBECs (Figure 18B).

A

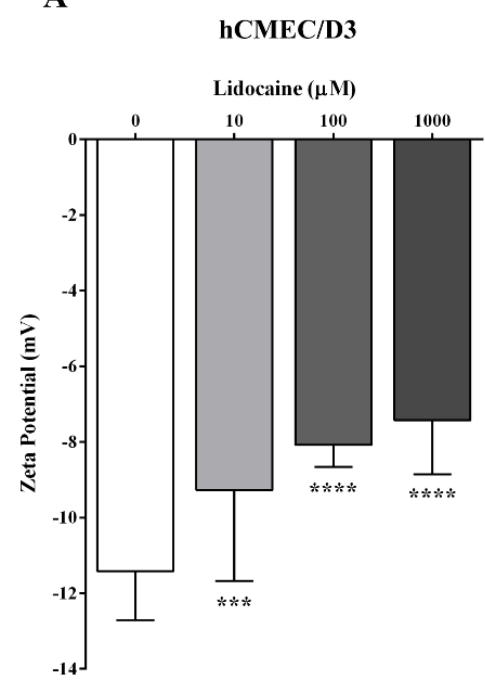

B

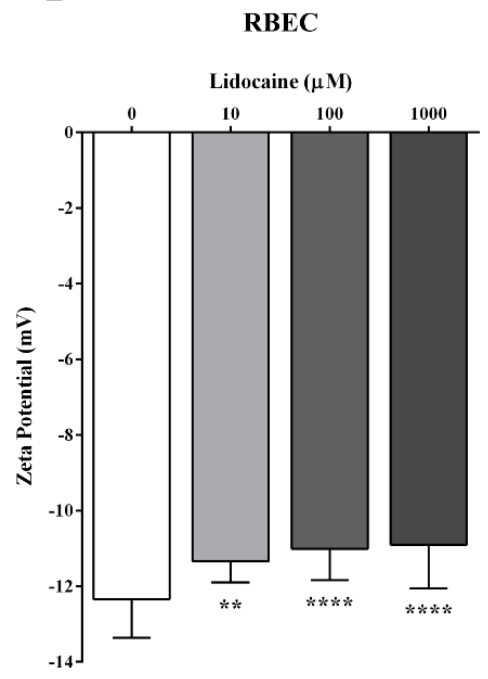

Figure 18. Effects of lidocaine on the surface charge of brain endothelial cells. (A) Cell cultures of the human brain endothelial cell line hCMEC/D3. (B) rat primary brain endothelial cells (RBEC). Cells were treated with different concentrations of lidocaine for $30 \mathrm{~min}$ to measure changes in the surface zeta potential $(n=10-29)$. Values of each group are presented as mean \pm SD. Data were analyzed by one-way ANOVA followed by Bonferroni post-test. ${ }^{* *} p<0.01$, $* * * \mathrm{p}<0.001, * * * * \mathrm{p}<0.0001$ compared to the untreated control and between treatments.

Since lidocaine is metabolized very quickly in the body by the liver, the $30 \mathrm{~min}$ treatment window was chosen. The background zeta values became more positive after treatment with increasing lidocaine concentrations in both cases (Figure 18) proving that lidocaine changes the surface charge of brain endothelial cells.

\subsubsection{Integrity of the BBB models after lidocaine treatment}

In clinical patients toxic side effects of lidocaine were only seen above $5 \mu \mathrm{g} / \mathrm{ml}$ $(21.7 \mu \mathrm{M})$ plasma concentration (Brunton and Chabner, 2011). To use a clinically relevant, but not toxic concentration of lidocaine, $10 \mu \mathrm{M}$ was used for the study of barrier 
integrity in the BBB models. In order to determine the tightness of the barrier after lidocaine treatment, the TEER of hCMEC/D3 and primary co-culture (RBEC) models was measured (Figure 19A-B).

hCMEC/D3

A

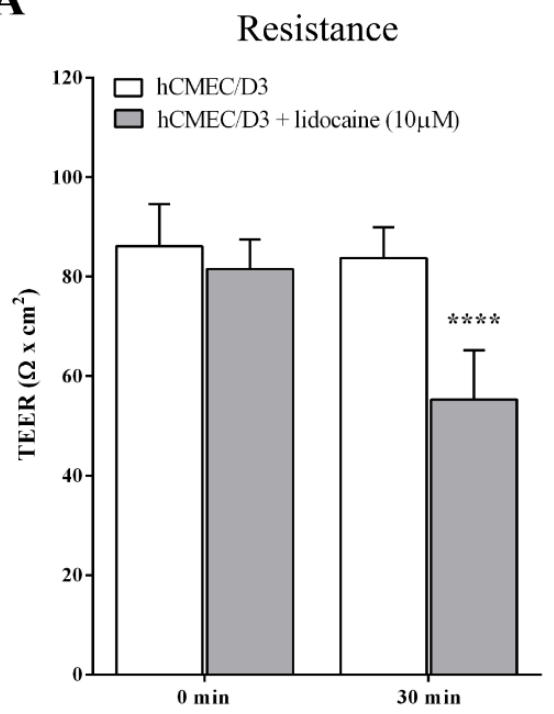

C

Permeability

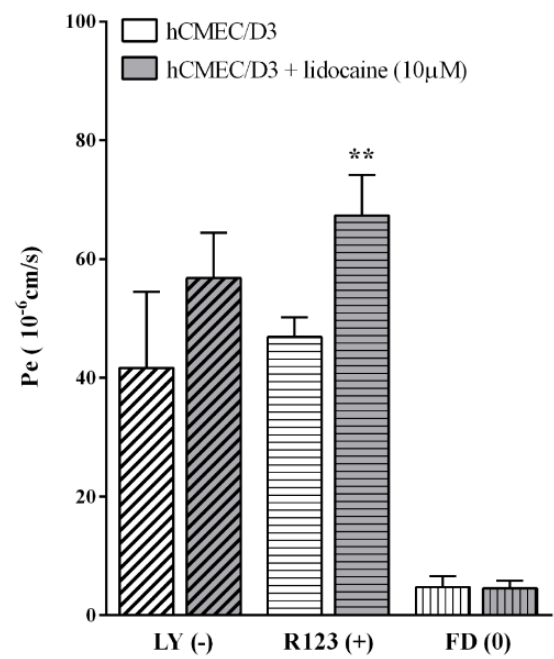

RBEC

B

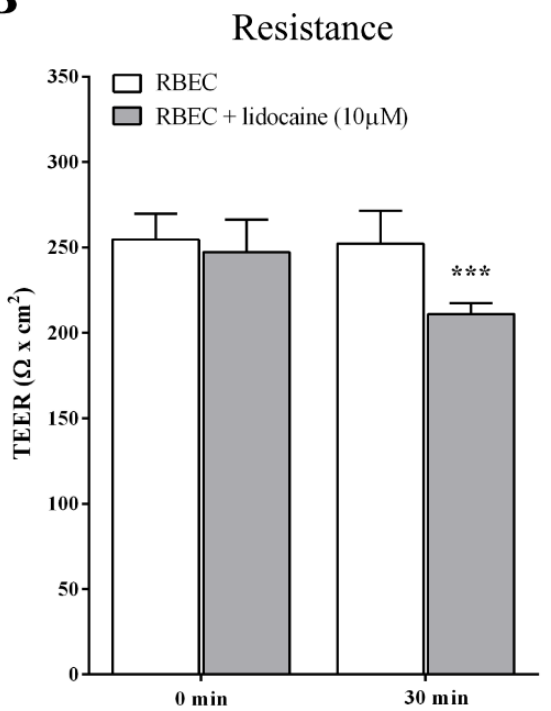

D

Permeability

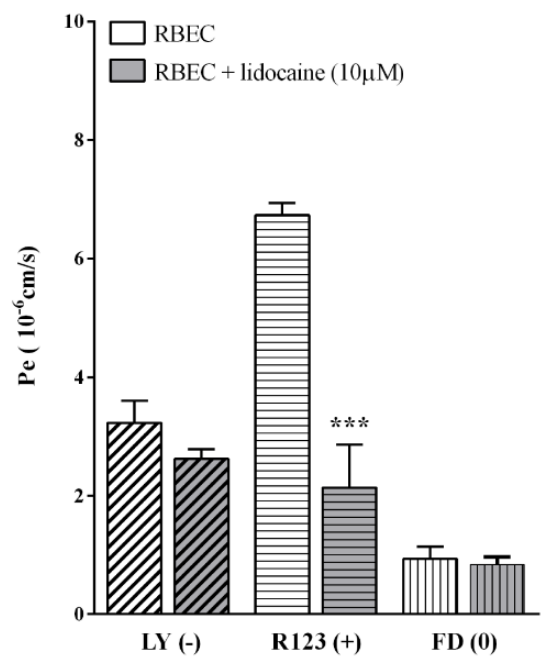

Figure 19. Barrier integrity of blood-brain barrier models hCMEC/D3 human brain endothelial cell line and primary cell-based triple co-culture model (rat brain endothelial cells (RBEC) with pericytes and astroglia) after lidocaine treatment ( $10 \mu \mathrm{M}, 30 \mathrm{~min})$. (A)-(B): TEER measurements right before and $30 \mathrm{~min}$ after the lidocaine treatment $(\mathrm{n}=5-12)$. Two-way ANOVA and Bonferroni post-test. $* * * \mathrm{p}<0.001, * * * * \mathrm{p}<0.0001$, compared to the $0 \mathrm{~min}$. (C-D): Endothelial permeability coefficient $\left(\mathrm{P}_{\mathrm{e}}\right)$ of cells treated with lidocaine for three differently charged tracers: Lucifer yellow (LY, negatively charged), rhodamine 123 (R123, positively charged) and FITC-Dextran (FD, no charge $(\mathrm{n}=4)$. Unpaired t-test, ${ }^{*} \mathrm{p}<0.01 ; * * * \mathrm{p}<0.001$. Values for all the groups was mean $\pm \mathrm{SD}$. 
There was a 3-fold difference between the TEER values of the two BBB models showing that the primary co-culture model better restricts the movement of ions as compared to the simplified human BBB model. Lidocaine treatment (10 $\mu \mathrm{M}, 30 \mathrm{~min})$ decreased the TEER of both models. The TEER drop in hCMEC/D3 cells was 35\% (84 \pm 6 to $55 \pm 10 \Omega \times \mathrm{cm}^{2}$ ) while on the triple co-culture BBB model was only $17 \%$ $\left(252 \pm 19\right.$ to $\left.211 \pm 6 \Omega \times \mathrm{cm}^{2}\right)$.

Since lidocaine modified the surface charge of brain endothelial cells, we hypothesized that the permeability of charged molecules across the BBB models might also change. Three differently charged fluorescent markers were used to determine their permeability across brain endothelial cells after lidocaine treatment. In the hCMEC/D3 cell line model the permeability for the water soluble negatively charged marker LY and neutral marker FD did not change as compared to the control group but the cationic molecule R123 showed an increased flux after lidocaine treatment (Figure 19C). Similarly, when the primary BBB co-culture model was studied (Figure 19D), no change was observed for the LY and FD, although the $\mathrm{P}_{\mathrm{e}}$ values of the markers were much smaller (LY: $10 \%$, FD: $30 \%$ of the $\mathrm{P}_{\mathrm{e}}$ in hCMEC/D3 model) showing once more that the integrity of the barrier is stronger in the co-culture model. Compared to the cell line model the permeability of the cationic marker, R123, decreased after lidocaine treatment (Figure 19C).

Since R123 is not only a positively charged lipophilic compound, but also a ligand of the Pgp efflux pump, we investigated whether lidocaine interferes with the activity of the Pgp function. Bidirectional permeability assay was performed, which showed that the Pgp blocker cyclosporin A, increased the R123 flux in AB direction and decreased it in the opposite direction across the primary BBB model (Figure 20). In contrast, lidocaine treatment (10 $\mu \mathrm{M}, 30 \mathrm{~min}$ ) decreased the permeability of R123 across RBECs from the $\mathrm{AB}$ direction and did not change the flux towards the BA direction, indicating that lidocaine does not inhibit the activity of the Pgp efflux pump.

This result is in accordance with our hypothesis which presumes that the interaction of lidocaine with the membrane charge decreases the permeability of another lipophilic cationic marker given concomitantly across the $\mathrm{BBB}$ if the paracellular pathway is closed. 


\section{Pgp function assay}

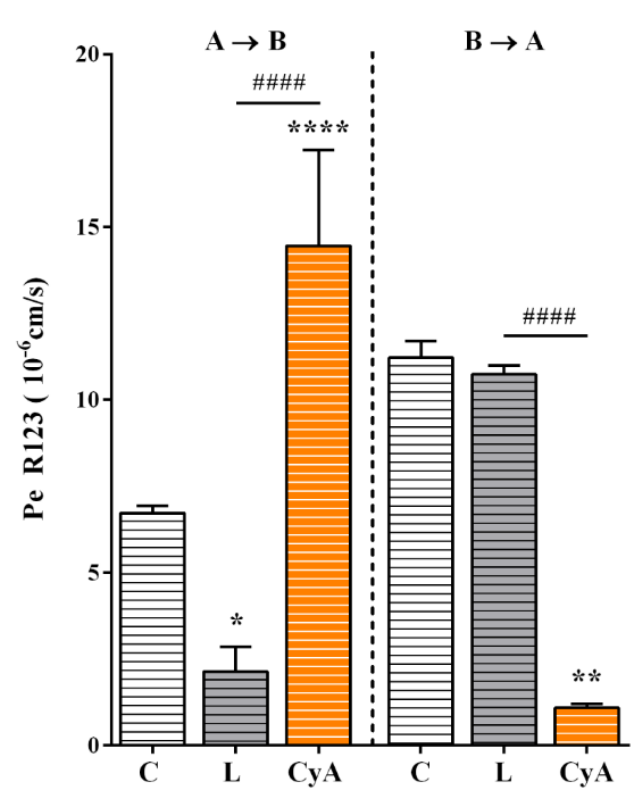

Figure 20. Effects of lidocaine on the P-glycoprotein efflux pump activity in primary rat brain endothelial cells (RBEC). Permeability of rhodamine 123 (R123) was measured from the luminal to the abluminal (A to B) and from the abluminal to the luminal (B to A) compartment after $30 \mathrm{~min}$ treatment with lidocaine or 1 hour with P-glycoprotein pump inhibitor cyclosporin A (CyA) $(n=4)$. Values are presented as mean \pm SD. Data were analyzed by one-way ANOVA followed by Bonferroni post-test. $* \mathrm{p}<0.05, * * \mathrm{p}<0.01, * * * *, \# \#+\mathrm{p}<0.0001$, compared to the control and between groups. C: control, L: lidocaine.

To further confirm the effects of lidocaine on brain endothelial barrier integrity, immunostaining was performed for junctional proteins $\beta$-catenin, $\mathrm{ZO}-1$ and claudin-5 (Figure 21 A-B). The subcellular expression of junctional proteins after lidocaine treatment was evaluated by image analysis measuring the fluorescent intensity in different cellular compartments (Figure $21 \mathrm{C}-\mathrm{D}$ ). In the control groups of both BBB models the immunostaining was mainly located at the cell borders, where the interendothelial junctions are found. RBECs showed elongated morphology with close cell-cell contacts (Figure 21B). After $10 \mu \mathrm{M}$ lidocaine treatment a slight change in cellular morphology was visible in both models. Immunostaining for $\beta$-catenin showed a cytoplasmic rearrangement of this linker protein both in the hCMEC/D3 and the RBEC models. Similar change was observed in hCMEC/D3 cells for ZO-1 protein. Claudin-5 was not detectable in this cell line. RBECs showed a redistribution of the claudin-5 tight junction protein after lidocaine treatment (Figure 21B-D) which was also reflected by the modest TEER decrease (Figure 19B). 
hCMEC/D3

A
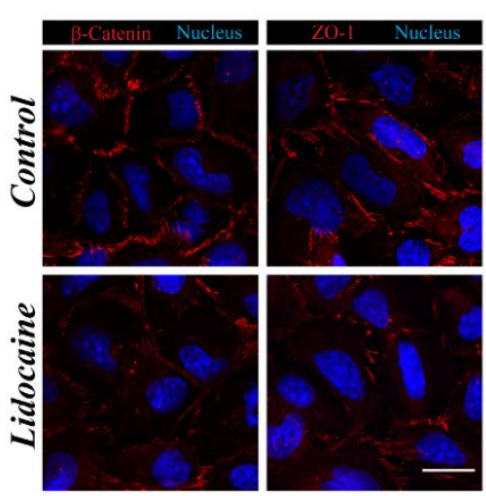

C

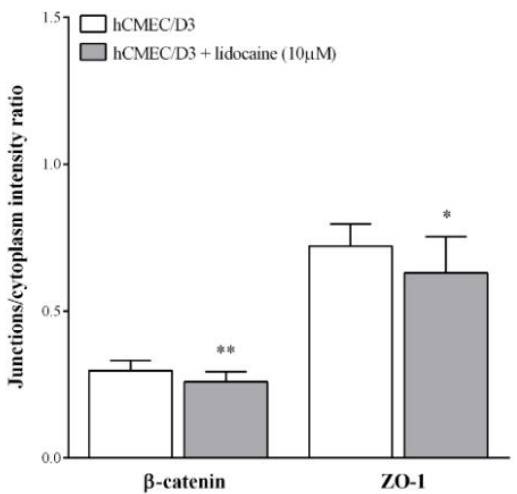

RBEC

B

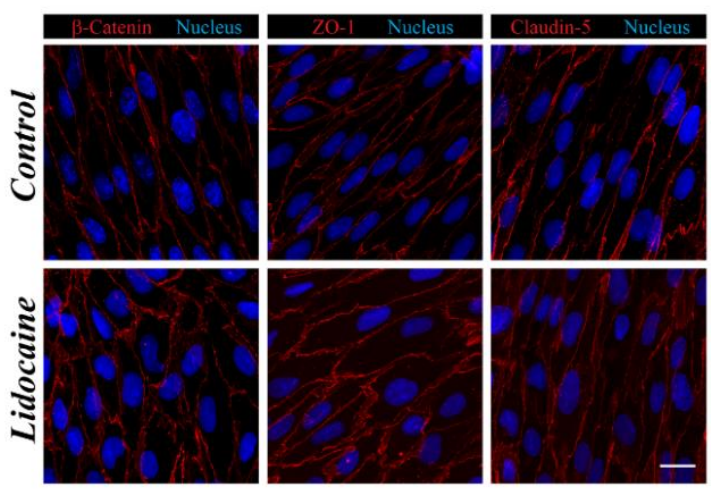

D

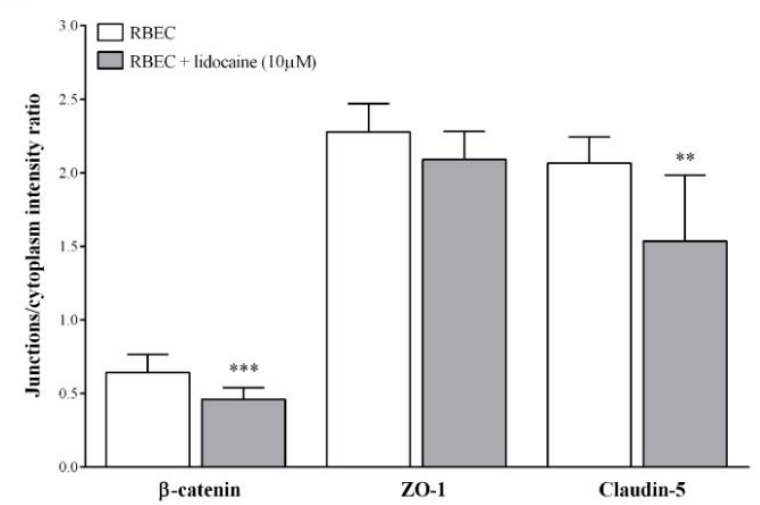

Figure 21. (A-B): Effects of lidocaine treatment (10 $\mu \mathrm{M}, 30 \mathrm{~min})$ on $\beta$-catenin, $\mathrm{ZO}-1$ and claudin5 immunostaining in hCMEC/D3 human brain endothelial cell line and rat primary brain endothelial cells (RBECs). Red: staining for junctional proteins. Blue: $\mathrm{H} 33342$ staining of cell nuclei. Scale bar: $20 \mu \mathrm{m}$. (C-D): Intensity ratio of the junctional and the cytoplasmic immunostaining $(n=11-15)$. Values are presented as mean \pm SD. Data were analyzed by unpaired t-test. $* \mathrm{p}<0.05, * * \mathrm{p}<0.01,{ }^{* * *} \mathrm{p}<0.001$, compared to the untreated control of the respective model.

In brain endothelial cells from the primary cell based triple co-culture BBB model (RBEC) the fluorescent intensity of the immunostaining for junctional proteins claudin-5 and ZO-1 in the cell membrane is higher than in the cytoplasm (Figure 21D) as compared to the hCMEC/D3 model, confirming the functional barrier integrity findings in all our studies shown in the present work and in our previous publications (Walter et al., 2016; Veszelka et al., 2018).

\subsection{Characterization of a human BBB model in a lab-on-a-chip device}

\subsubsection{Effect of flow on barrier properties of the human BBB model}

The human BBB model has been characterized and comparisons of ECs in monoculture vs. co-culture with brain pericytes have been described in static cell culture insert conditions (Cecchelli et al., 2014; Heymans et al., 2020). The goal of our 
experiments was to characterize the human BBB co-culture model in our LOC device and specifically, determine the effect of fluid flow. The LOC has two fluid compartments, similarly to culture inserts: a porous PET membrane separates the top and bottom channels (Figure 8A). One of the biggest advantages of the LOC compared to the cell culture insert setup is the possibility of applying fluid flow to induce shear stress and mimic more physiological conditions on brain EC cultures (Walter et al., 2016). As in the case of cell culture inserts (Cecchelli et al., 2014; Heymans et al., 2020), ECs were added to the top compartment, and PCs were seeded to the bottom compartment of the LOC device (Figure 8C). The tightness of the barrier was characterized by measurement of TEER and permeability for LY and albumin, as described for the other BBB models in the previous sections. As shown in Figure 22A 24-hour fluid flow elevated the TEER significantly by $18 \%\left(361.8 \pm 166.3 \Omega \times \mathrm{cm}^{2}\right.$ to $\left.425.5 \pm 188.8 \Omega \times \mathrm{cm}^{2}\right)$. The paracellular permeability for LY was significantly decreased after fluid flow by $77 \%$ (27.2 \pm 9.7 to $6.4 \pm 2.8 \times 10^{-6} \mathrm{~cm} / \mathrm{s}$ ) similarly to permeability for EBA, which was significantly decreased by $88 \%\left(1.76 \pm 0.02\right.$ to $\left.0.12 \pm 0.01 \times 10^{-6} \mathrm{~cm} / \mathrm{s}\right)$ after dynamic condition (Figure 22B). The morphology of BLECs also changed after dynamic as compared to static condition. After flow, a more elongated cell shape was visible (Figure 22C) than in cells under static condition.

A

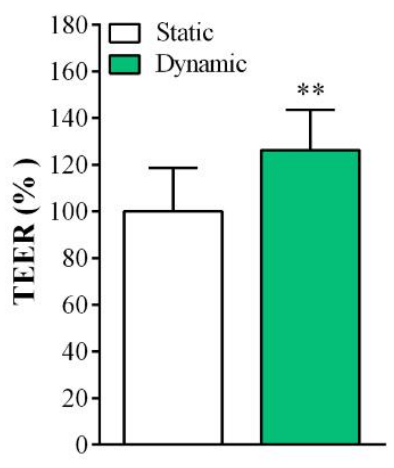

B

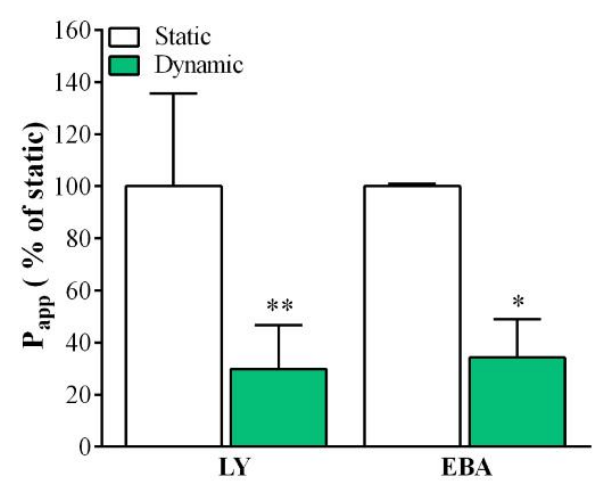

C

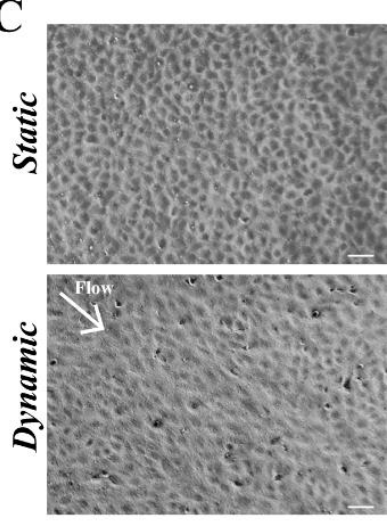

Figure 22. Characterization of the human BBB model in the lab-on-a-chip (LOC). (A) TEER results were normalized to the values of the static condition which did not receive any fluid flow $(\mathrm{n}=12)$. (B) Apparent permeability coefficient $\left(\mathrm{P}_{\mathrm{app}}\right)$ of the human BBB model under static and dynamic conditions for Lucifer yellow (LY) and Evans-blue labeled albumin (EBA) marker molecules. Data is shown as the \% of the static condition and presented $(n=2-4)$. (C) Phase contrast images of brain endothelial cells under static and dynamic conditions. Scale bar: $100 \mu \mathrm{m}$. Values are presented as means $\pm \mathrm{SD}$, Unpaired t-test, ${ }^{*} \mathrm{p}<0.05,{ }^{*} \mathrm{p}<0.01$. 
The change in brain endothelial cell (BLEC) shape in dynamic condition was also evident in pictures taken of immunostaining for TJ protein claudin- 5 and cytoplasmic AJ linker protein $\beta$-catenin (Figure 23). Brain pericytes showed a branched and polygonal morphology and stained for $\alpha$-smooth muscle actin, PDGFR- $\beta$ and NG2 throughout all experiments (Figure 23).

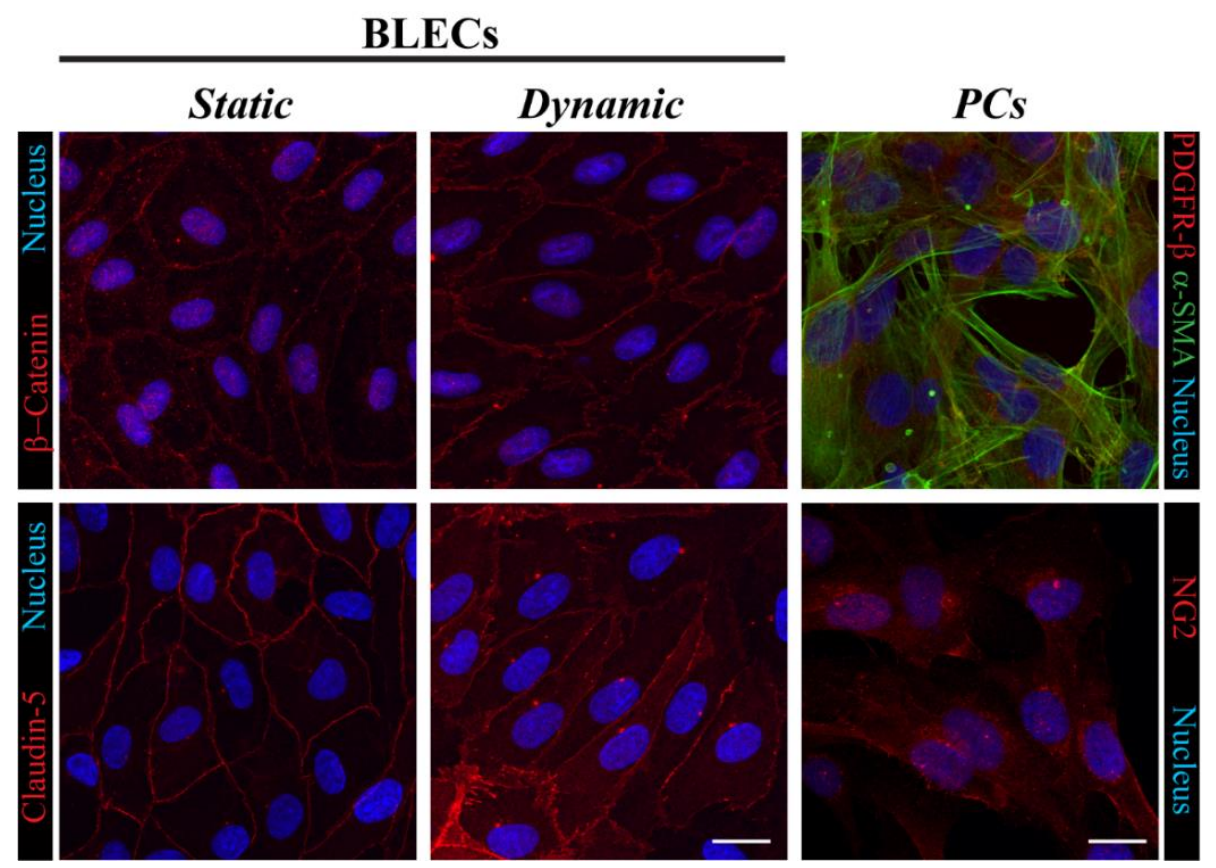

Figure 23. Cell morphology characterized by immunostaining. Claudin-5 and $\beta$-catenin junctional proteins of brain like endothelial cells (BLECs) were labeled under static or dynamic conditions (red). Brain pericytes (PCs) were characterized by PDGF receptor- $\beta, \alpha$-smooth muscle actin ( $\alpha$-SMA) and NG2 markers followed by visualization with confocal microscopy. Scale bar: $20 \mu \mathrm{m}$.

\subsubsection{Effect of flow on the global gene expression profile}

To further characterize the effect of fluid flow on the human BBB co-culture model, a transcriptomic gene expression profile of BLECs was performed using the MACE-seq. Gene expression profiling analysis was able to detect expressions from 28,807 different genes. A total of 396 genes had a p-value lower than 0.05 and an $|\log 2 \mathrm{FC}|>1$, which were considered differentially expressed (Figure 24B). From all the expressed genes, $174(0.6 \%)$ and $222(0.8 \%)$ were up and down regulated, respectively (Figure 24A). Using more stringent thresholds of $|\log 2 \mathrm{FC}|>2$ or $<-2,67(0.2 \%)$ upregulated and $73(0.3 \%)$ downregulated genes were identified. 
A

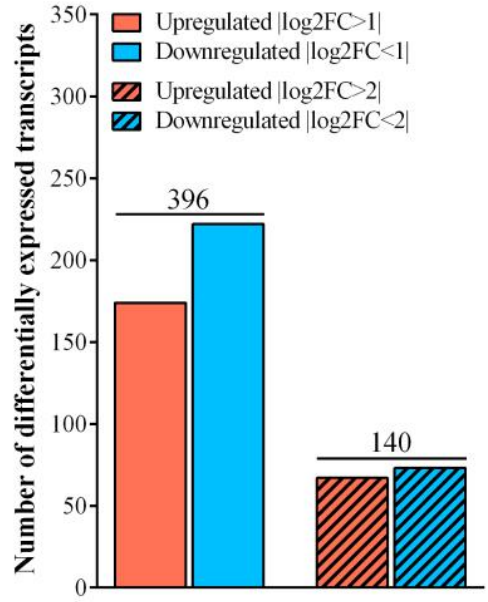

B

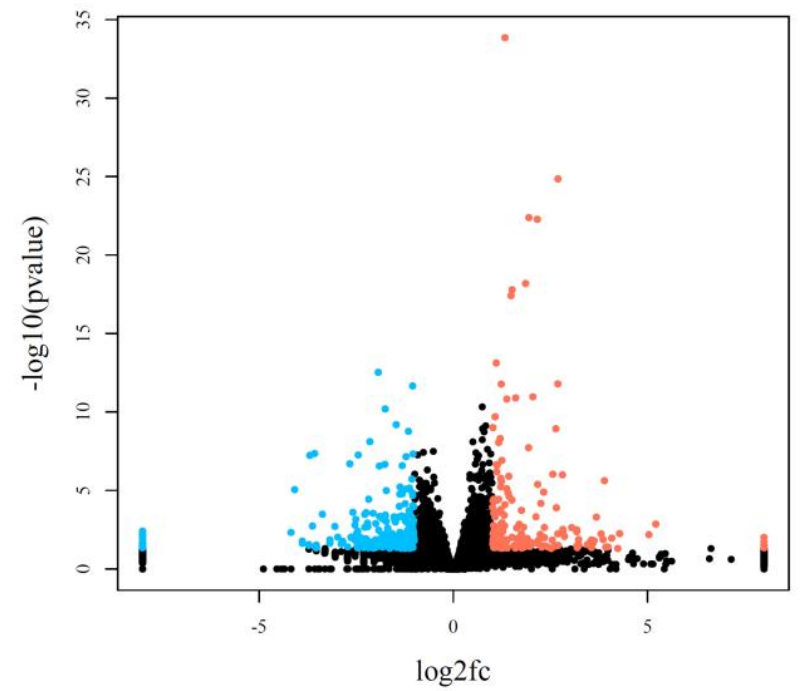

Figure 24. (A) Number of differentially expressed transcripts of human endothelial cells cocultured with brain pericytes under dynamic and static conditions. The total number of differentially expressed transcripts are shown in top of the bars. Testing for differential gene expression was performed using the DESeq2 R/Bioconductor package (Love et al., 2014). (B) The volcano plot identifies the total changes in the data set. Black: no change, Blue: downregulated genes, Red: upregulated genes.

\subsubsection{Effect of flow on endothelial cell markers}

During the analysis of MACE data, the influence of fluid flow on the expression of general endothelial markers and other endothelial cell-related genes was verified. Several basic endothelial marker genes were expressed in BLECs, including von Willebrand factor (VWF), vascular endothelial growth factor genes (VEGFA, B, C) and their receptors (VEGFR1-3), angiopoietins (ANGPT1 and 2), endothelial cell specific molecule 1 (ESM1) and endothelial nitric oxide synthase (NOS3), as expected. Many of these genes were not changed by flow (Figure 25A). Among the endothelial genes 24hour fluid flow significantly upregulated endothelin 1 (EDN1), nitric oxide synthase interacting protein (NOSIP) and vascular endothelial growth factor receptor 1 (VEGFR1) (Figure 25A) and downregulated the lymphatic vessel endothelial marker gene LYVE1.

In dynamic conditions among the adhesion molecules (Figure 25B) the expression of intercellular adhesion molecule-1 gene (ICAM1) was significantly elevated. Flow did not change the gene expression of other members of this group, such as adhesion regulating molecule-1 (ADRM1), activated leukocyte cell adhesion molecule (ALCAM), CD99, and vascular cell adhesion molecule-1 (VCAM1), while L-selectin gene (SELL) was downregulated. 
A

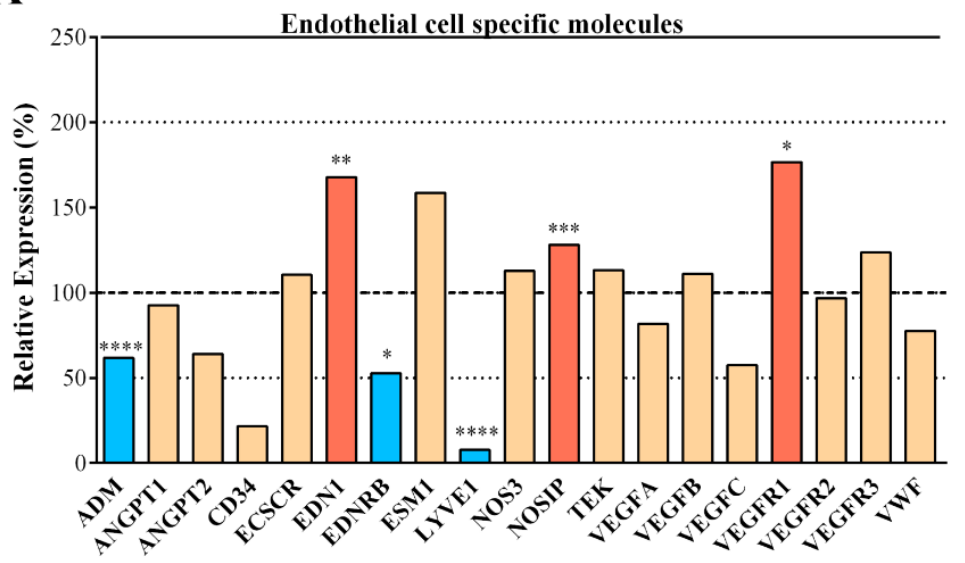

B

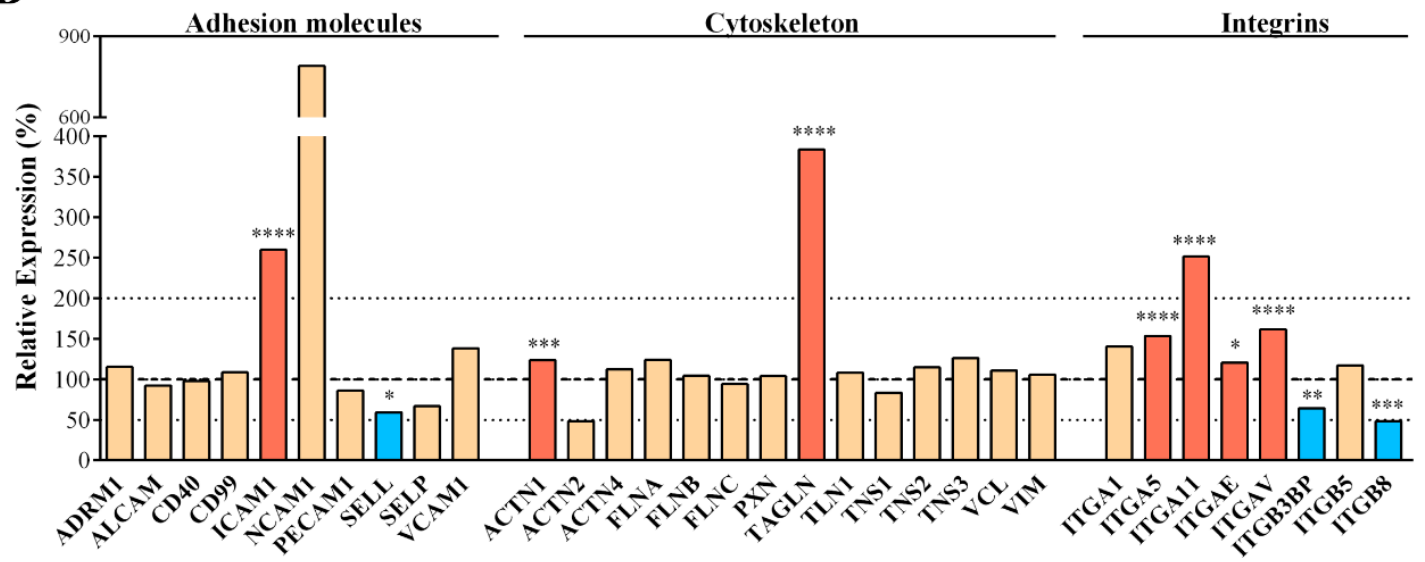

C

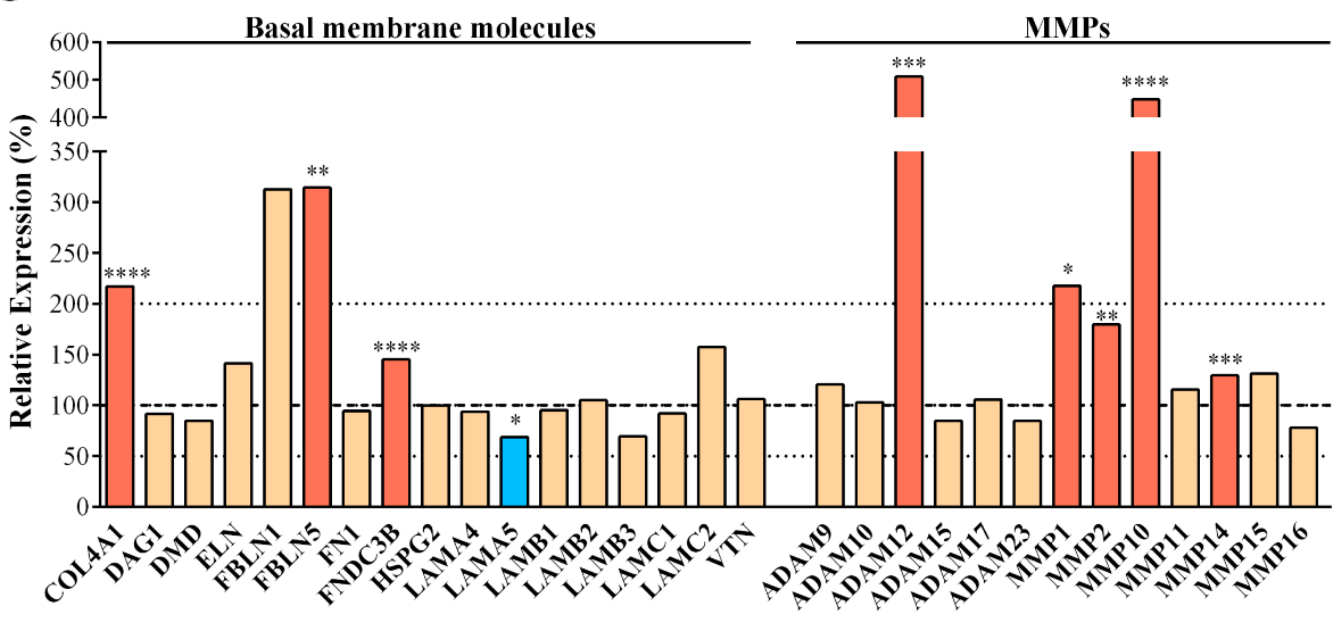

Figure 25. Transcriptomic gene expression profile of (A) endothelial cell specific genes, (B) endothelial cell adhesion molecule, cytoskeleton molecule and integrin genes, (C) basal membrane molecule and matrix metalloproteinase (MMP) genes. Expression is shown as the relative expression (\%) of the genes present in human endothelial cells co-cultured with brain pericytes in dynamic condition as compared to static condition. Genes with a p-value $<0.05$ and less than $50 \%$ or more than $200 \%$ gene expression levels were differentially expressed. Red color labels upregulation and statistically significant expression changes, blue color shows downregulation and statistically significant expression change, cream color indicates no change in the gene expression $(* \mathrm{p}<0.05, * * \mathrm{p}<0.01, * * * \mathrm{p}<0.001, * * * * \mathrm{p}<0.0001)$. 
Flow had no effect on endothelial cytoskeleton genes of the human BBB model, including actinins (ACTN), filamin (FLN), talin (TLN), tensin (TNS), vinculin (VCL) and vimentin (VIM), while significantly increased the expression of $\alpha$-actinin-1 (ACTN1) and the actin cross-linker transgelin (TAGLN) genes. Importantly, genes for several members of the integrin family, especially $\alpha$-subunits (ITGA5, ITGA11, ITGAE, ITGAV) were overexpressed after flow (Figure 25B), along with a number of brain endothelial basal membrane genes like collagen type IV (COL4A1), as well as fibulin 5 (FBLN5), FNDC3B and members of the matrix metalloproteinase family (MMP1, -2, 10, -14) (Figure 25C). From the members of the ADAM (a disintegrin and metalloproteinases) families expressed only one gene, ADAM-12 was upregulated by fluid flow in the human BBB model. Several basal membrane genes were unchanged by the dynamic conditions, including dystrophin (DMD), elastin (ELN), perlecan or basement membrane-specific heparan sulfate proteoglycan core protein (HSPG2), laminins (LAM) and vitronectin (VTN). The significant upregulation of genes for cytoskeleton proteins, integrins and basal membrane molecules indicate pathways leading to better attachment of the cell layer at the abluminal side and demonstrate the importance of dynamic conditions in the human BBB model to better mimic physiological conditions in vitro.

\subsubsection{Effect of flow on BBB-related genes}

Several TJ transmembrane or linker proteins were present at an unchanged level after the dynamic condition, including endothelial cell-selective adhesion molecule (ESAM), occludin (OCLN), claudin-12 (CLDN12), junctional adhesion molecule 3 (JAM3), MARVELD1 and -D2, zonula occludens protein-1 and -2 (TJP1 and TJP2) (Figure 26A). The gene expression level of JAM1 and CLDN1, -3, -5 and -7 was decreased after flow condition (Figure 26A).

Among AJ proteins the gene expression level of vascular endothelial or VEcadherin (CDH5), neuronal or N-cadherin ( $\mathrm{CDH} 2)$, nectin-2 and $-3, \alpha-$ and $\beta$-catenin (CTNNA1 and CTNNAB1) remained unchanged, while the expression levels of Ecadherin (CDH1) and protocadherins-1 and -9 (PCDH1 and PCDH9) genes increased. Genes for gap junction proteins, known to be involved in intercellular communication and the regulation of TJs and AJs, connexin 43 (GJA1) and connexin 40 (GJA5) were significantly upregulated by dynamic condition (Figure 26A). 
A

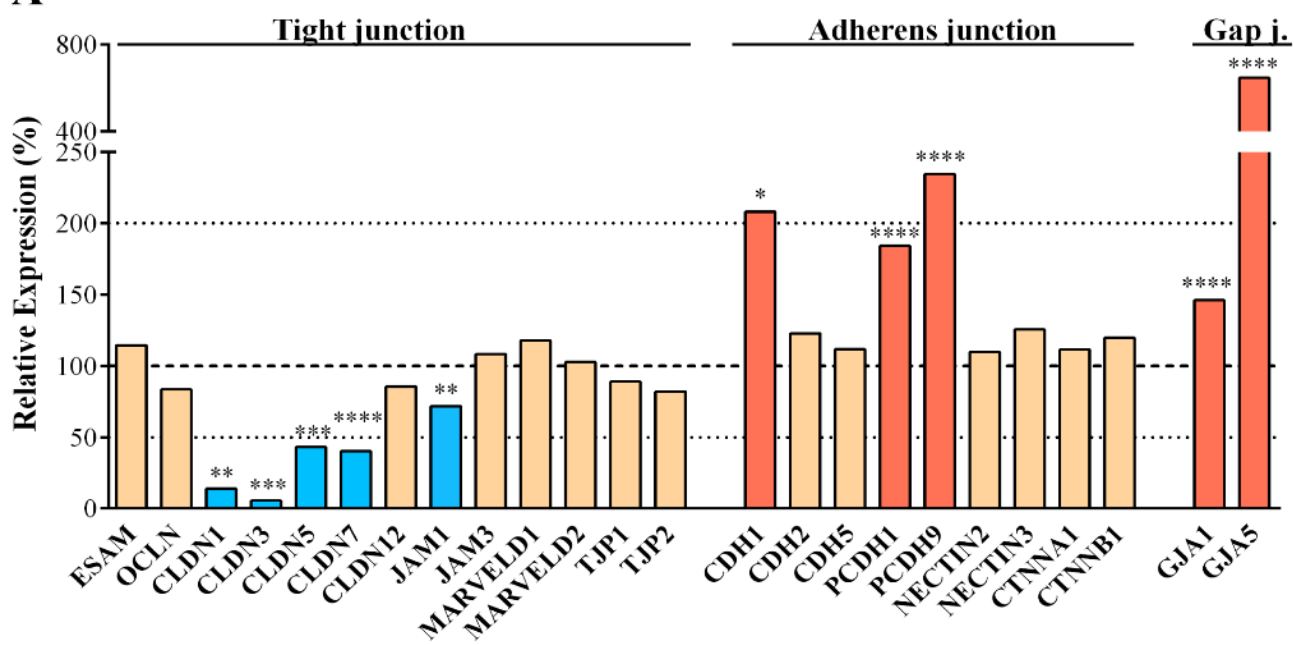

B

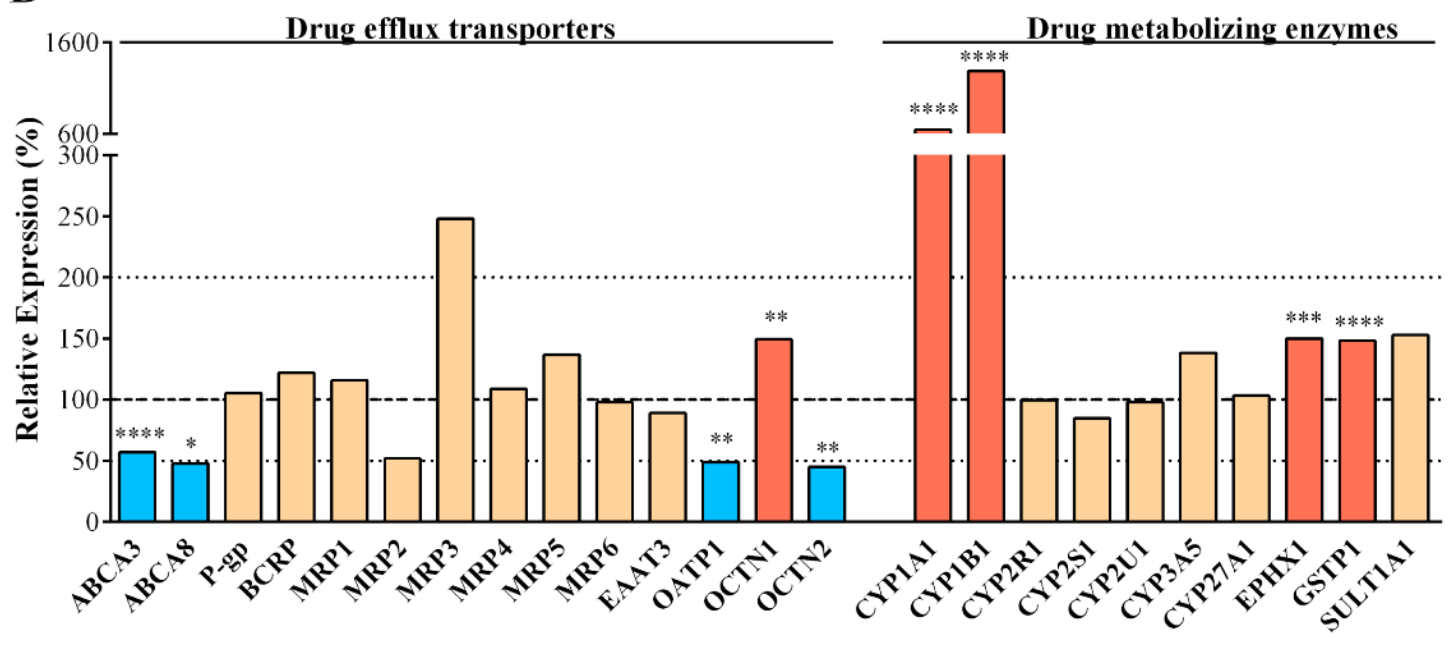

Figure 26. Transcriptomic gene expression profile of (A) tight, adherens and gap junction protein genes, (B) drug efflux transporter and drug metabolizing enzyme genes. Expression is shown as the relative expression (\%) of the genes present in human endothelial cells co-cultured with brain pericytes in dynamic condition as compared to static condition. Genes with a p-value $<0.05$ and less than $50 \%$ or more than $200 \%$ gene expression levels were differentially expressed. Red color labels upregulation and statistically significant expression changes, blue color shows downregulation and statistically significant expression change, cream color indicates no change in the gene expression $(* \mathrm{p}<0.05, * * \mathrm{p}<0.01, * * * \mathrm{p}<0.001, * * * * \mathrm{p}<0.0001)$.

Active efflux pumps and drug metabolizing enzymes represent an important line of defense at the level of the BBB by providing protection against toxic chemical compounds. As shown in Figure 26B the gene expression levels for many of the ATP cassette binding $(\mathrm{ABC})$ family and other transporters participating in drug and metabolite efflux, such as ABCB1 (P-glycoprotein, P-gp), ABCG2 (breast cancer resistance protein, BCRP), members of the ABCC family (ABCC1-6 or MRP1-6) and the excitatory amino acid transporter-3 belonging to the solute carrier (SLC) family (SLC1A1/EAAT3) were unchanged after flow condition. Other transporters, like the lipid transporters ABCA3 and 
ABCA8, expressed in both peripheral and brain tissues, were significantly downregulated along with the organic anion-transporting polypeptide 1 (SLCO4A1/OATP1) and the organic cation transporter-2 (SLC22A5/OCTN2) after applying the dynamic condition. The only drug efflux transporter gene upregulated after dynamic conditions was the organic cation transporter-1 (SLC22A4/OCTN1).

The cytochrome (CYP) P450 enzymes, which participate in steroid and drug metabolism (drug metabolism phase I enzymes) and thus contribute to subsequent efflux of conjugated drugs at the $\mathrm{BBB}$, are expressed in different barrier culture models (Veszelka et al., 2018). Many members of the CYP family were expressed in the human BBB model and the CYP1A1 and CYP1B1 genes were significantly overexpressed if flow was applied (Figure 26B). Additionally, under the same conditions, drug metabolism phase II enzymes of the BBB, epoxide hydrolase-1 (EPHX1) and glutathione Stransferase $\pi$ (GSTP1), were also upregulated (Figure 26B).

Solute carriers are abundantly expressed at the BBB (Campos-Bedolla et al., 2014; Blanchette and Daneman, 2015; Veszelka et al., 2018). Glucose transporters, like GLUT1, -10, -11 and -12 (SLC2A1, -10, -11 -12) were expressed with an unchanged level, while SLC2A6 (GLUT6) and SLC2A13 (GLUT13/HMIT) were significantly overexpressed under flow conditions (Figure 27A).

Genes for six monocarboxylate transporters, involved in the transport of lactate, pyruvate, ketone bodies and thyroid hormones, were expressed in BLECs. No change was seen in their expression level after applying flow to the BLECs, except for SLC16A4 (MCT4) which was significantly elevated (Figure 27A).

From the large family of amino acid transporters most genes were present at an unchanged level. It was found that three genes in this group were upregulated by flow: the sodium-dependent neutral amino acid transporter SLC1A4 (ASCT1), the cationic amino acid transporter SLC7A2 (CAT2) and the chloride dependent cystine-glutamate antiporter SLC7A11 (xCT). Only one gene, SLC7A5 (LAT1), was found to be downregulated (Figure 27A). The expression levels of the peptide transporters SLC15A4 (PHT1) and SLC15A3 (PHT2) were not changed by fluid flow (Figure 27A). The creatine transporter SLC6A8 (CRT) was significantly upregulated after dynamic conditions were applied, while the copper transporter SLC31A2 (CTR2) was not. 
A

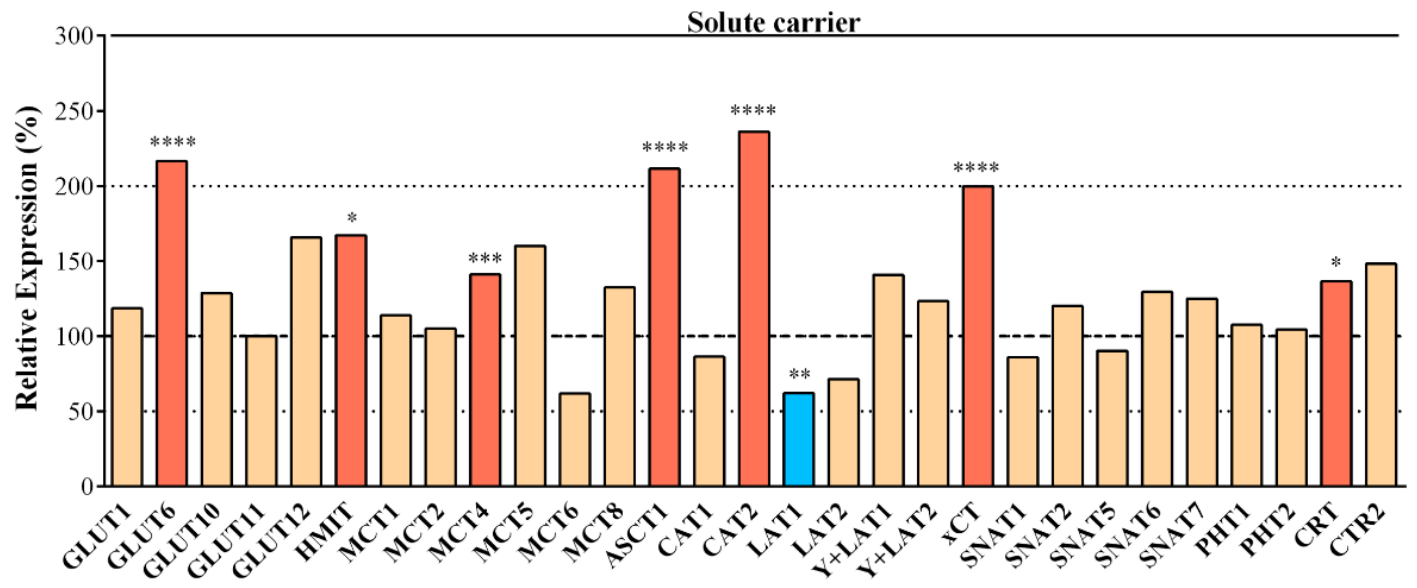

B

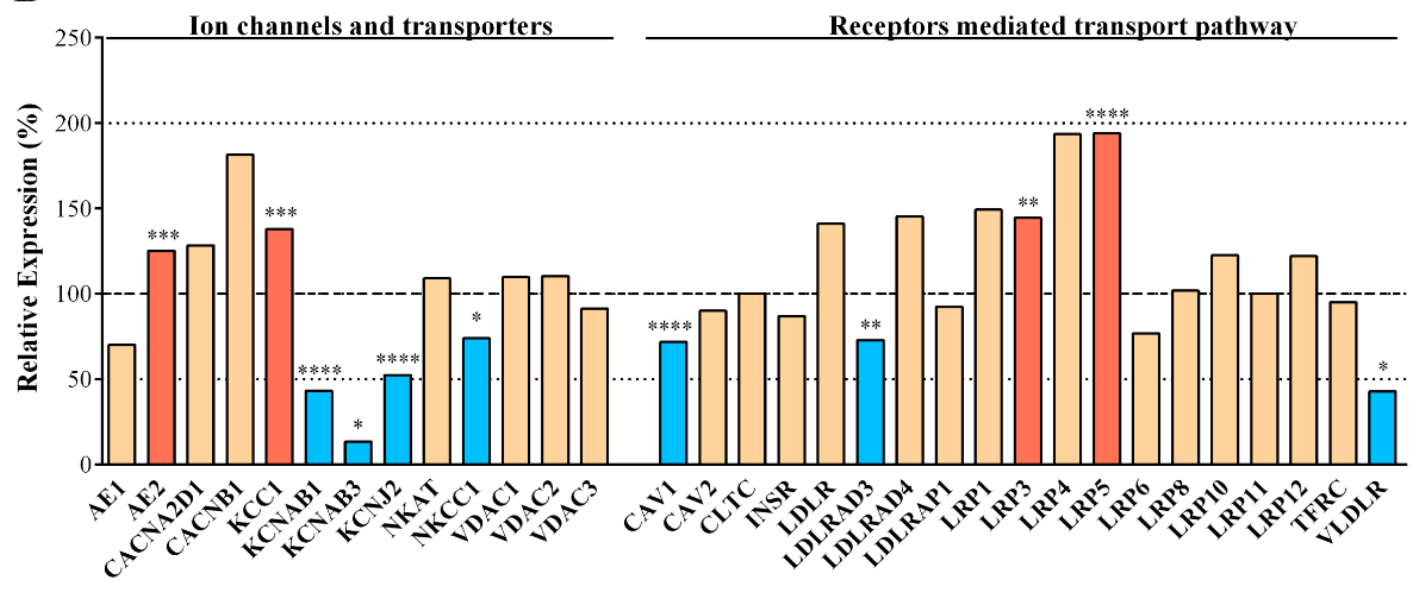

Figure 27. Transcriptomic gene expression profile of (A) solute carrier genes and (B) ion channel and transporter, and receptor mediated transport pathway-related genes. Expression is shown as the relative expression (\%) of the genes present in human endothelial cells co-cultured with brain pericytes in dynamic condition as compared to static condition. Genes with a p-value $<0.05$ and less than $50 \%$ or more than $200 \%$ gene expression levels were differentially expressed. Red color labels upregulation and statistically significant expression changes, blue color shows downregulation and statistically significant expression change, cream color indicates no change in the gene expression $(* \mathrm{p}<0.05, * * \mathrm{p}<0.01, * * * \mathrm{p}<0.001, * * * * \mathrm{p}<0.0001)$.

Several ion transporters, pumps and channels are expressed at the BBB (Sweeney et al., 2019), which we also could confirm in the present study (Figure 27B). We found that flow conditions did not change the gene expression of the anion exchanger-1 (SLC4A1/AE1), pre-proteins for voltage-gated $\mathrm{Ca}^{2+}$ channel subunits (CACNA2D1 and CACNB1), the $\mathrm{Na}^{+} / \mathrm{K}^{+}$ATPase (ATP1A1/NKAT), and the voltage dependent anion channels (VDAC1-3). Two genes were upregulated: the $\mathrm{HCO}_{3}{ }^{-} \mathrm{Cl}^{-}$exchanger SLC4A2 (AE2) and the $\mathrm{K}^{+}-\mathrm{Cl}^{-}$cotransporter SLC12A4 (KCC1) (Figure 27B). Flow conditions downregulated the expression of the voltage-gated $\mathrm{K}^{+}$channel $\mathrm{K}_{\mathrm{v}} 1$ subunits $(\mathrm{KCNAB} 1$ 
and $\mathrm{KCNAB} 3$ ), the $\mathrm{K}_{\mathrm{ir}} 2.1$ inward-rectifier $\mathrm{K}^{+}$channel $(\mathrm{KCNJ} 2)$, and the $\mathrm{Na}^{+}-\mathrm{K}^{+}-\mathrm{Cl}^{-}$ cotransporter-1 (SLC12A2/NKCC1) genes.

The penetration of peptides, proteins and lipoproteins through the BBB are controlled by receptor-mediated transporters (Sweeney et al., 2019). The presence of many important BBB receptor genes was detected on the human BBB model cultured in the LOC device (Figure 27B). Most of these were not changed by flow, including insulin receptor (INSR), members of the low density lipoprotein receptor family (LDLR, LDLRAD4, LDLRAP1), members of the low density lipoprotein receptor related protein family (LRP1, -4, -6, -8, -10, -11, -12) or the transferrin receptor (TFRC). Dynamic condition increased the expression levels of two receptor genes, LRP3 and LRP5 and decreased the level for LDLRAD3 and very low-density lipoprotein receptor (VLDLR). Caveolins regulate endocytosis, transcytosis and signaling in lipid-base domains; the expression level of caveolin-1 (CAV1) gene was decreased upon flow condition, while the expression of CAV2 and clathrin (CLTC) was not changed (Figure 27B).

\subsubsection{The effect of fluid flow on the endothelial surface charge and glycocalyx of the human BBB model cultured in the lab-on-a-chip device}

The endothelial surface glycocalyx plays an important role in the mechanosensing and transduction functions of endothelial cells, which are essential to maintain vascular integrity and homeostasis (Fu and Tarbell, 2013). In the previous sections, we showed the modulation of the endothelial surface charge and glycocalyx by an enzyme and a small molecule drug. The in vitro BBB models based on cell culture inserts lack fluid flow, hence represent a static environment. The ESG and the extracellular matrix are important elements of the defense system of the BBB, therefore it is crucial to understand how fluid flow changes the surface charge and glycocalyx of brain endothelial cells. As described above, fluid flow promotes the expression of many BBB-related genes in BLECs. We observed that genes coding glycocalyx core proteins, like decorin (DCN), glypican-1 (GPC1), syndecan-2 (SDC2) and versican (VCAN) were significantly upregulated in the dynamic condition (Figure 28). Other ESG core protein genes like biglycan (BGN), CD44, and other syndecans (SDC1, -3, -4) were also present, but their expression levels were not changed by the flow. Four types of galectins that bind specifically to $\beta$-galactoside sugars within the glycocalyx were expressed in BLECs (GAL1, -3, -8 and -9), from which galectin-3 (GAL3) expression was decreased by flow (Figure 28). The human BBB model expressed many enzymes that participate in the 
synthesis and remodeling of the ESG (Figure 28). The genes of four enzymes, carbohydrate sulfotransferase-1 (CHST1), heparinase (HPSE), hyaluronidase-2 (HYAL2) and the heparan sulfate 6-O-endosulfatase SULF2, which selectively removes 6-O-sulfate groups from heparan sulfate, were found to be upregulated on the BLECs under flow, while the expression of only one enzyme, $\beta$-1,4-galactosyltransferase- 5 (B4GALT5) decreased.

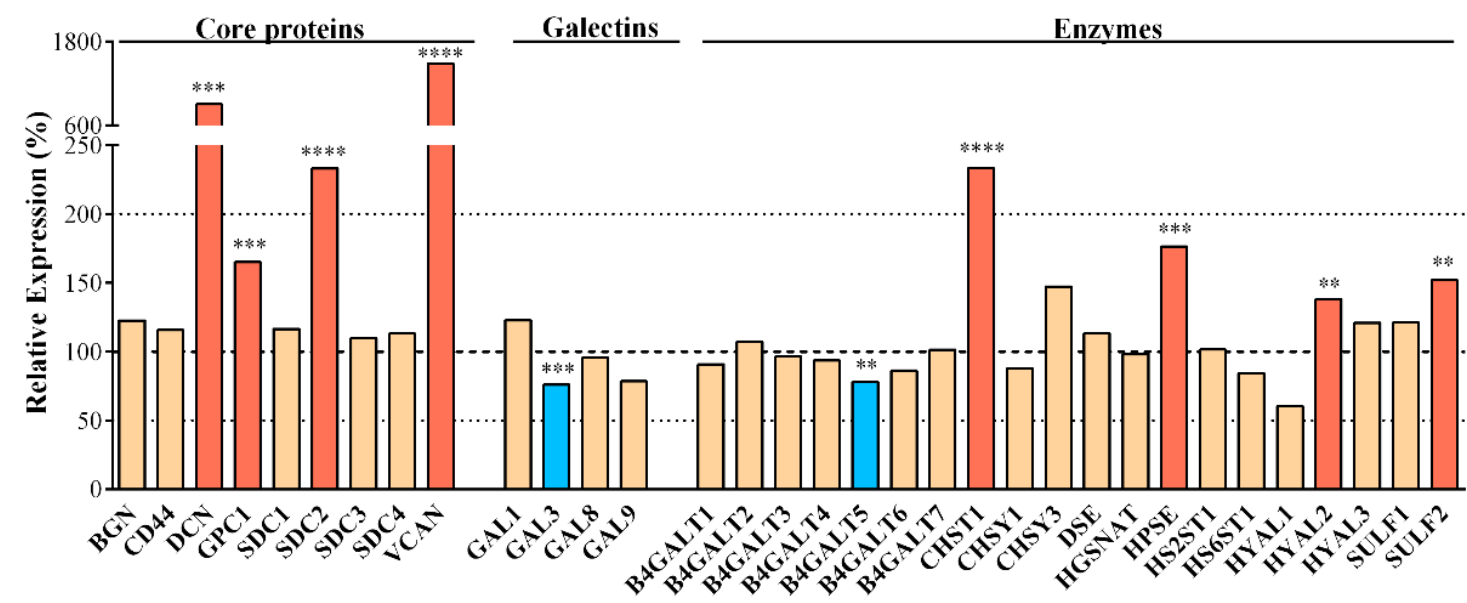

Figure 28. Transcriptomic gene expression profile of endothelial surface glycocalyx-related genes. Expression is shown as the relative expression (\%) of the genes present in human endothelial cells co-cultured with brain pericytes in dynamic condition as compared to static condition. Genes with a p-value $<0.05$ and less than $50 \%$ or more than $200 \%$ gene expression levels were differentially expressed. Red color labels upregulation and statistically significant expression changes, blue color shows downregulation and statistically significant expression change, cream color indicates no change in the gene expression $(* * p<0.01, * * * p<0.001$, $* * * * \mathrm{p}<0.0001)$.

Brain EC glycocalyx is one of the thickest within the vasculature (Ando et al., 2018) and also cultured brain ECs have highly negative surface charge (as we demonstrated in section 4.2.2 and 4.3.2.) compared to other cell types (Ribeiro et al., 2012).The main sources of this negative charge are the lipid head groups of the plasma membrane and the ESG, composed of highly negatively charged polysaccharide chains. Since ESG related genes were upregulated by flow, zeta potential was measured in order to determine if the changes at gene expression influence the absolute value of the surface charge of BLECs. A significant decrease in surface charge of BLECs (Figure 29A) was observed for cells cultured under dynamic condition $(-12.4 \pm 1.4 \mathrm{mV})$ compared to static condition $(-11.0 \pm 1.0 \mathrm{mV})$. 
A

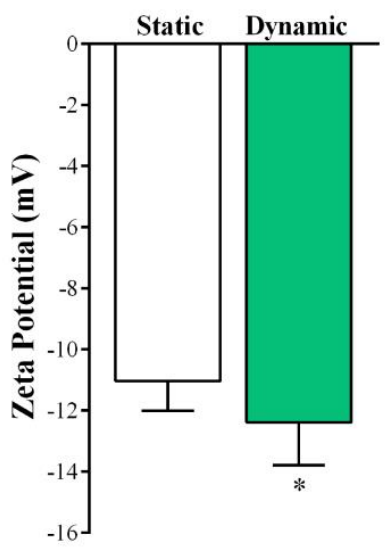

B

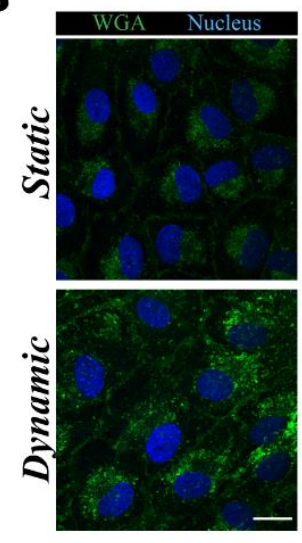

C

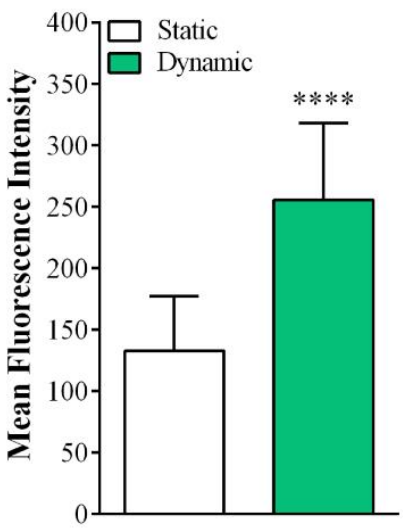

Figure 29. (A) Zeta potential measured by laser Doppler velocimetry (means $\pm S D, n=10$; unpaired t-test, $* \mathrm{p}<0.05$ compared to static condition). (B-C) Staining of ESG on brain endothelial cells with fluorescently labelled wheat germ agglutinin (WGA) lectin. Scale bar: $20 \mu \mathrm{m}$. Image analysis values are presented as means $\pm \mathrm{SD}, \mathrm{n}=72$; unpaired t-test, $* * * * \mathrm{p}<0.0001$ compared to static condition.

The more negative surface charge was related to a denser ESG as confirmed by the fluorescently labelled WGA lectin staining: a 90\% increase in the fluorescence intensity was observed in the confocal images after 24-hour flow (Figure 29B-C).

The effect of flow on the ESG was corroborated by the gene enrichment profiles (Figure 30). The most significantly upregulated pathways after the introduction of flow conditions were the extracellular matrix and structure pathways and the ESG-related pathways.

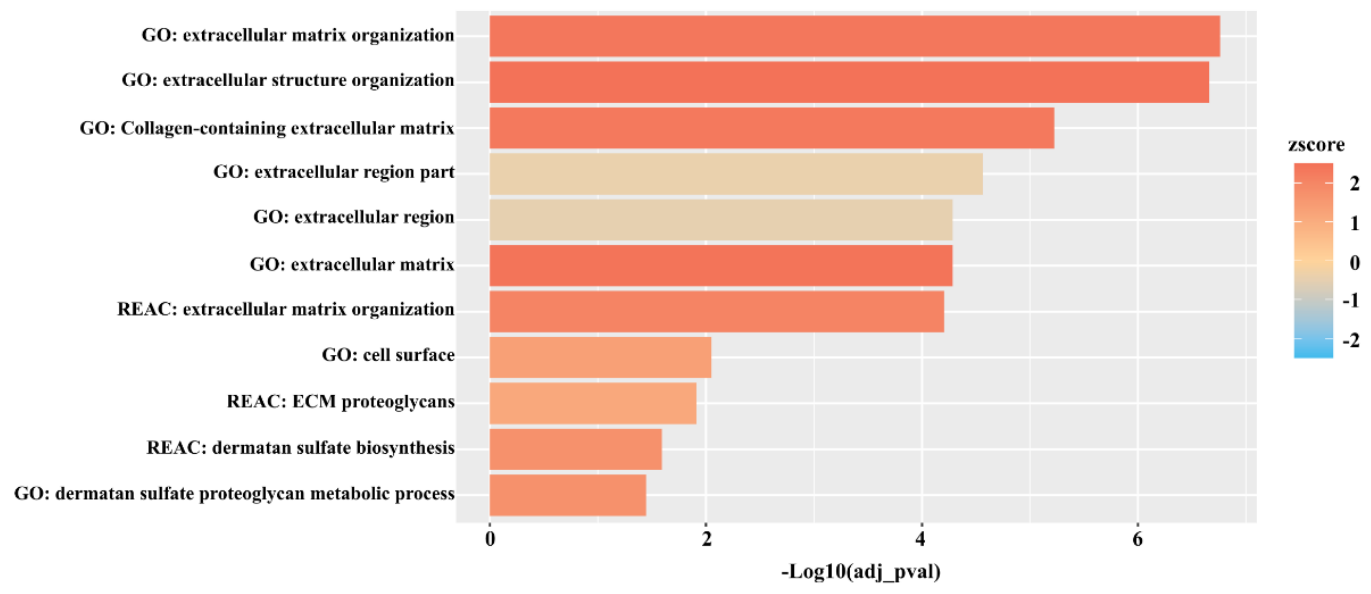

Figure 30. Functional profiling analysis of extracellular matrix-related pathways in static versus dynamic condition. The $\mathrm{x}$-axis represents the statistical significance calculated using g:Profiler while the z-score represents the tendency of the regulation of these pathways calculated using GO plot. 


\section{Discussion}

\subsection{BBB models in cell culture inserts and lab-on-a-chip device}

$\mathrm{BBB}$ culture models are important tools to investigate brain EC functions, CNS pathologies with brain microvessel involvement and transport mechanisms to the brain (Walter et al., 2016; Veszelka et al., 2018). Different methodologies have been developed to obtain in vitro $\mathrm{BBB}$ models that are easy to prepare, reliable, reproducible and costeffective. The cells for these BBB models can come from three major sources. If they are directly and freshly isolated from animal or human tissues, they are called primary cells (Nakagawa et al., 2009; Helms et al.,2016). Immortalized brain endothelial cell lines are popular due to their easier handling (Weksler et al., 2005, Veszelka et al., 2011; Helms et al., 2016). In recent years the use of BBB models prepared from cells differentiated from human stem cells has been steadily growing (Cecchelli et al., 2014; Lippmann et al., 2012).

Primary cell-based BBB models are considered as the closest functionally to the in vivo $\mathrm{BBB}$, although no ideal model exists (Helms et al., 2016). In our laboratory we use rat primary brain ECs co-cultured with primary brain pericytes and astrocytes, a model which has been extensively characterized (Nakagawa et al., 2009; Veszelka et al., 2018). The drawbacks of using primary cultures are the technical complexity of the isolation process, the need for fresh brain tissue, the relatively high cost and the low number of passages to avoid the loss of cell-specific properties. In our triple co-culture model we keep primary rat brain ECs and PCs on the two opposite sides of a porous cell culture membrane with primary rat astrocytes at the bottom of cell culture plate wells (Figure 5). This co-culture setup has the highest barrier integrity compared with other murine BBB models or cell lines (Veszelka et al., 2011; Helms et al.,2016) presenting a high TEER reaching on average 3-500 $\Omega \times \mathrm{cm}^{2}$ and a low permeability for fluorescein $\left(\sim 1 \times 10^{-6} \mathrm{~cm} / \mathrm{s}\right)$ and albumin $\left(\sim 0.1 \times 10^{-6} \mathrm{~cm} / \mathrm{s}\right)$ markers (Nakagawa et al., 2009; Veszelka et al., 2018). Similar observations were made in the present study: the primary rat model showed the highest TEER and the lowest permeability on cell culture inserts compared to the human cell based BBB models.

Several studies observed species differences in the amount of key BBB transporters and receptors highlighting the need of human BBB models for pharmacological studies and drug discovery (Ohtsuki et al., 2014). Human immortalized brain endothelial cell lines emerged as potential tools. The hCMEC/D3 human brain EC 
line, developed 15 years ago, is a simplified BBB model, and as other immortalized brain EC line, remains viable and presents specific BBB properties for several passages with a high reproducibility between experiments (Weksler et al., 2013). In the present study, we could observe a lower TEER and increased permeability of hCMEC/D3 cells when compared with the other BBB models (Figure 10 and 19). Immunostaining for TJ proteins in hCMEC/D3 cells also showed a lower expression and altered pattern of intercellular junctional proteins than in the primary co-culture model (Figure 11 and 21). This relative leakiness of the paracellular pathway is the biggest drawback of this model, in agreement with observations in our previous comparative study (Veszelka et al., 2018) and literature data (Helms et al., 2016).

To solve the problems and limitations of the primary cell-based and immortalized cell line BBB models, stem cell-derived models have recently been emerging. Since there are controversies related to the induced pluripotent stem cell based BBB models (Lippmann et al., 2020), we have adapted in our laboratory a BBB model based on hECs differentiated from cord blood stem cells (Cecchelli et al., 2014). In this novel human model first hematopoietic stem cells are differentiated to vascular ECs, which produce brain-like EC properties when in co-culture with bovine or human brain pericytes (Cecchelli et al., 2014; Heymans et al., 2020). This model shows BBB properties and expresses several BBB markers (Cecchelli et al., 2014; Heymans et al., 2020). However, similarly to the immortalized hCMEC/D3 human cell line, the TEER values are in the lower range, indicating a much less tight barrier than our primary cell based model (Figure 10-11). In the present study, we aimed to culture the BBB models in a LOC device and compare to the cell culture insert setup. For the triple co-culture model and the hCMEC/D3 human cell line similar functional and morphological characteristics were obtained in both setups. For the human BBB co-culture model in the LOC we could observe changes as compared to the culture inserts (Figure 10-11). We hypothesize that the following factors may be responsible for the positive effects observed in the BLECs: frequent medium change by automatic feeding and the elongated channel geometry.

\subsection{Modulation of the brain endothelial surface charge by neuraminidase and lidocaine}

The BBB has a special defense system formed by the TJs, efflux pumps and metabolic enzymes of brain ECs (Abbott et al., 2006; Deli, 2011). These lines of defense are strengthened by the negative surface charge of brain ECs, which derives from the lipid 
head groups and the ESG forming a physical barrier and regulating the transfer of charged molecules through the BBB (Hervé et al., 2008; Li and Fu, 2011; Ribeiro et al., 2011). Despite its potential importance in drug transport, the role of this negative surface charge at the BBB is not fully understood.

Sialic acid residues on the surface glycocalyx of brain ECs were visible in all the BBB models when stained with fluorescently labeled lectin (Figure 12) and we could also establish the measurement of the zeta potential of these cells. These observations suggested that the BBB culture models are suitable to study the modulation of the surface charge and glycocalyx of brain ECs by enzymes, drugs or fluid flow in our further studies. We used the hCMEC/D3 and the rat primary BBB models, well described, characterized and widely used in our laboratory (Walter et al., 2015a; Veszelka et al., 2018). In our experiments, we modified brain endothelial surface charge by two different ways: reducing negative charge from the glycocalyx using neuraminidase and making the charge of the plasma membrane more positive by lidocaine (Figure 31).

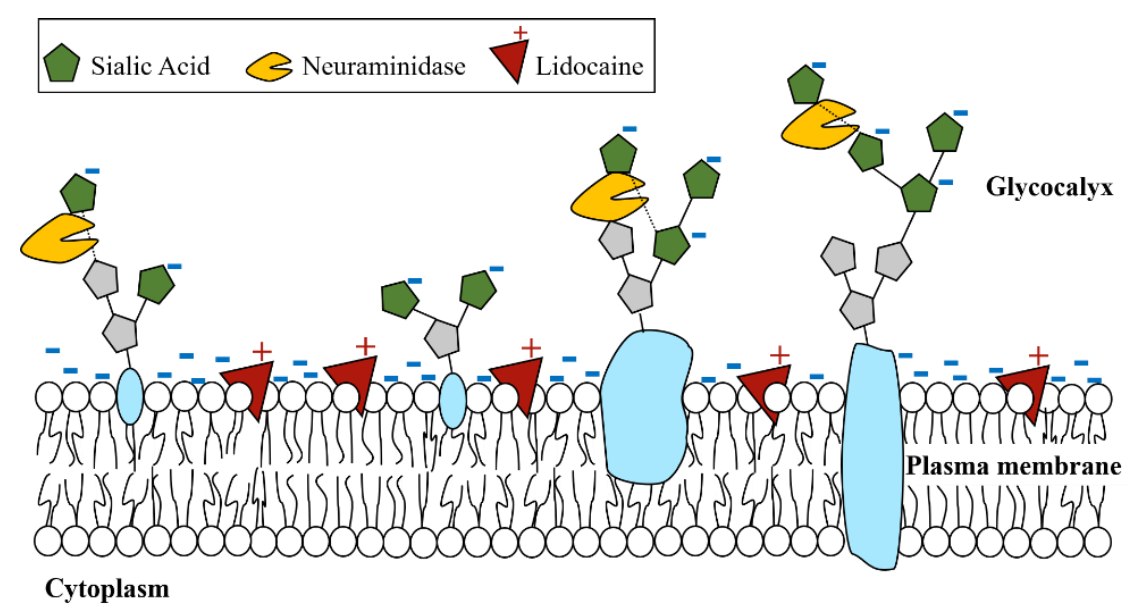

Figure 31. Modulation of brain endothelial surface charge by neuraminidase and lidocaine. Neuraminidase enzyme cleaves the sialic acids of the polysaccharide sidechains, thus decreases the amount of negative charge on the glycocalyx. Lidocaine incorporates into the cell membrane and makes its charge more positive.

The endothelial glycocalyx is composed of a negatively charged mesh of proteoglycans, glycosaminoglycans, glycoproteins and glycolipids (van den Berg et al., 2006). Glycocalyx shedding is observed in pathologies, like inflammation, sepsis, ischemia, chronic and acute renal diseases (Dogné and Flamion, 2020). This pathological event can be mimicked using neuraminidase, a glycoside hydrolase enzyme that cleaves sialic acids (Betteridge et al., 2017). We hypothesized, that the enzymatic cleavage of sialic acid residues from ESG will reduce the amount of negative charge and turn brain 
EC surface charge more positive. Indeed, we demonstrated that neuraminidase treatment significantly decreased the amount of sialic acid residues of the glycocalyx shown by lectin staining (Figure 14A-D) and consequently increased the zeta potential of brain ECs indicating less negative surface charge (Figure 15A-B). The removal of sialic acid residues from the ESG of brain ECs did not change the dextran and albumin permeability after neuraminidase treatment in vitro (Figure 16). In contrast, an increased permeability for albumin was observed in rat mesenteric microvessels after neuraminidase treatment (Betteridge et al., 2017). Since the enzyme concentration used in vivo was two times higher (2 U/ml) (Betteridge et al., 2017) than in our study, we cannot exclude, that in our case only a partial ESG digestion occurred not influencing albumin passage. However, we consider it more likely, that other mechanisms are responsible for the difference. First, the endothelial ESG is weaker in the periphery and stronger in the CNS (Ando et al., 2018). Additionally, the TJs are much stronger at the BBB and there is no basal plasma protein flux across brain ECs (Abbott et al., 2006). Comparative studies on cultured ECs from different tissues and vascular beds would be needed to reveal the details of this phenomenon.

The other method for surface charge modulation of brain ECs was performed using the lidocaine as a positively charged, membrane intercalating drug (Figure 31). Lidocaine is commonly used as a local anesthetic and has a clinically important role in the treatment of abnormal heart rhythm (Brunton and Chabner, 2011; Tsuchiya and Mizogami, 2013). When given intravenously, it can act directly on brain EC membranes and we hypothesized it might affect barrier properties of the BBB. The therapeutic plasma concentration of lidocaine is between 1.5 and $5 \mu \mathrm{g} / \mathrm{ml}(6.5-22 \mu \mathrm{M})$. In order to determine the direct effect of lidocaine on the viability of brain ECs, toxicity tests were performed. No change was seen in any of the assays for the tested concentrations, except for a reversible reduction of the cellular impedance at the highest, pharmacologically nonrelevant concentration of $1000 \mu \mathrm{M}$ (Figure 17). These data are in accordance with the low toxicity and the safe applicability of lidocaine as a therapeutic drug (Dan et al., 2018). Since lidocaine is metabolized by the liver within $2 \mathrm{~h}$ and the half-life of the drug is short in the blood (Brunton and Chabner, 2011; Dan et al., 2018), the clinically relevant $10 \mu \mathrm{M}$ concentration and the 30-min treatment window were selected to study the changes in surface charge and barrier function of the hCMEC/D3 and primary co-culture BBB models. 
While the hydrophobic interaction of lidocaine with the lipid bilayer of the cell membrane, including membrane fluidity, and its influence on protein channels has been explored (Yun et al., 2002; Tsuchiya and Mizogami, 2013), the effect of this drug on endothelial surface charge has not been measured directly. In the vascular system the surface charge of brain ECs is more negative than that of peripheral ECs (Ribeiro et al., 2012). This can be explained by the special lipid composition of the plasma membrane of brain ECs (Ribeiro et al., 2012; Campbell et al., 2014) and the denser structure of glycocalyx in the luminal surface of brain capillaries (Ando et al., 2018). In accordance with the first zeta potential measurements made on bovine brain EC suspension (Ribeiro et al., 2012), we found in the present study that the surface charge of human and rat brain ECs are negative and in the same range (Figure 18). The present data showing that surface charge is modulated by the interaction of lidocaine with the membrane is supported by previous findings using a cationic lipid probe, TMA-DPH. This probe inserts itself into the plasma membrane of cells and shifts zeta potential of brain ECs to more positive (Ribeiro et al., 2012). The positively charged ibuprofen-kyotorphinamide derivative not only increases the zeta potential of brain ECs, but the molecule has an increased analgesic effect in mice indicating higher penetration to the brain (Ribeiro et al., 2011).

The BBB restricts the transport of substrates, from ions to large molecules, between the blood and the CNS (Deli, 2011). The two major pathways for molecules and cells to cross the BBB are the paracellular (junctional) and the transcellular routes (Deli et al., 2005; Abbott et al., 2006). The measurement of TEER is the most sensitive method to assess the tightness of TJs in BBB models (Lénárt et al., 2015; Helms et al., 2016). The resistance of brain EC layers after lidocaine treatment was slightly, but significantly decreased by lidocaine (Figure 19 A-B) suggesting an increased paracellular ionic permeability. This change was reflected by the redistribution of the immunostaining for three junctional proteins, $\beta$-catenin, ZO-1 and claudin-5 in brain ECs from the plasma membrane to the cytoplasm after lidocaine treatment (Figure $21 \mathrm{~A}-\mathrm{B}$ ) which was quantified by image analysis (Figure $21 \mathrm{C}$-D). These data suggest that the interaction of positively charged drugs with brain ECs might affect the ionic permeability. There was no significant difference between the permeability for the negatively charged and hydrophilic markers, LY and FD in the control and the lidocaine treated groups (Figure 19 C-D). This result indicates that lidocaine treatment affects the paracellular pathway for ions, but not for larger water-soluble molecules (Figure 32). 
The other marker molecule, R123 is positively charged and lipophilic and crosses the tight BBB by the transcellular pathway. If the barrier is not tight, R123 is diffusing by both the trans- and the paracellular pathways (Figure 32). On the hCMEC/D3 model the permeability of the barrier to R123 after lidocaine treatment was increased (Figure 19C).

A hCMEC/D3

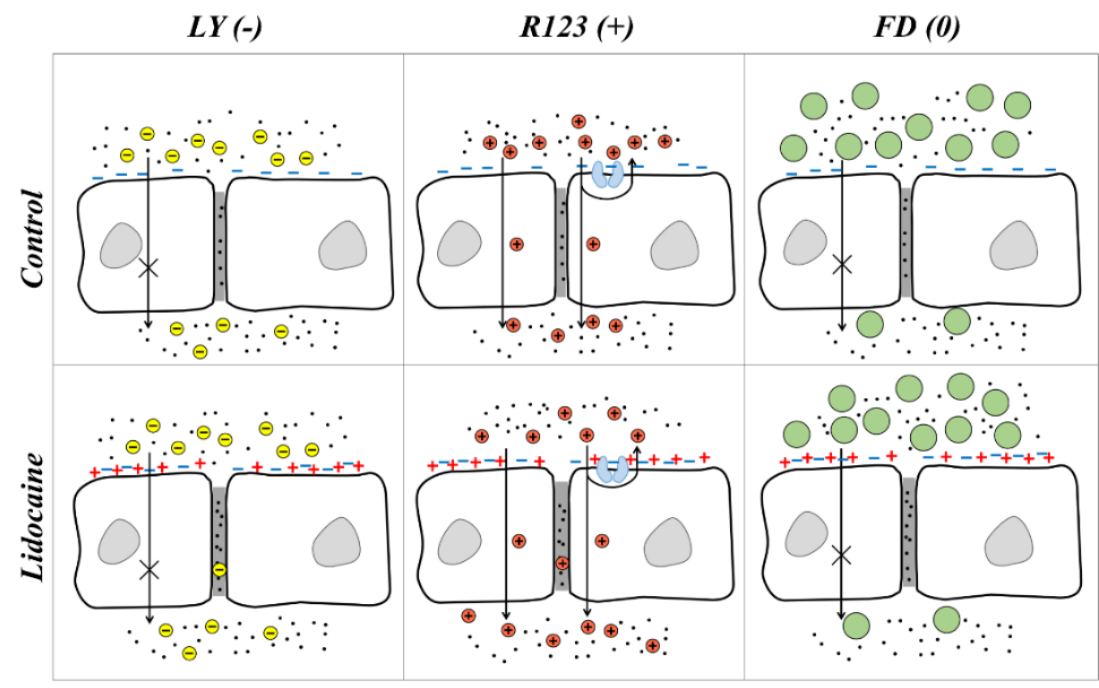

B RBEC

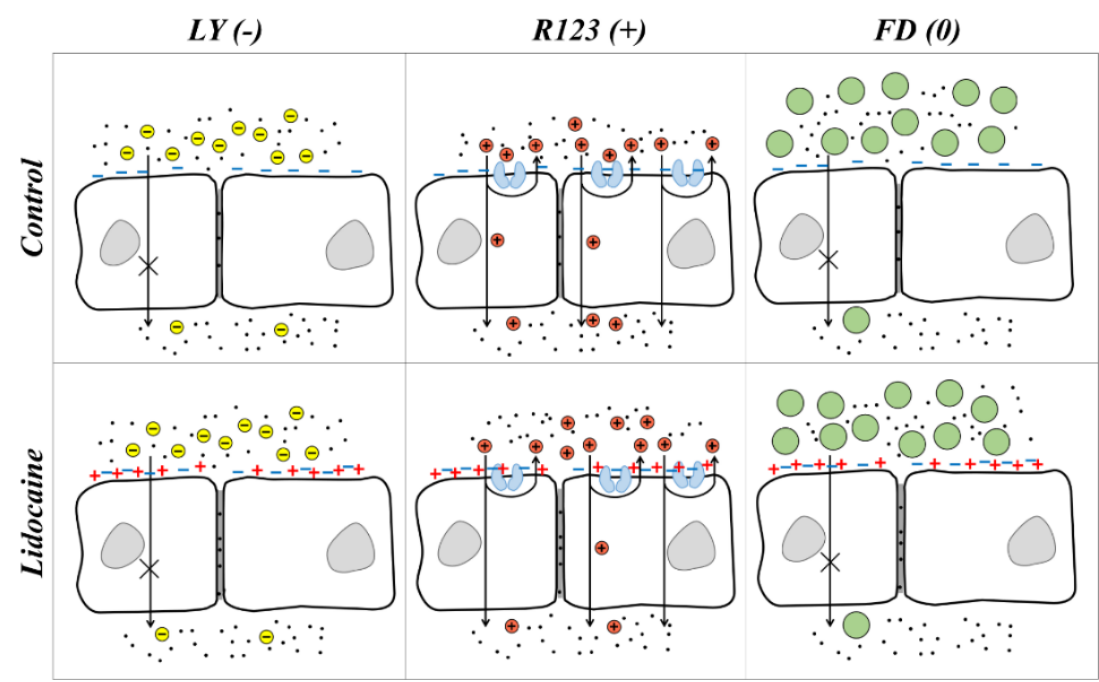

Figure 32. Drawings representing the passage of fluorescent marker molecules across human brain ECs (hCMEC/D3) and the primary rat brain endothelial model (RBEC) before and after lidocaine treatment. The flux of the negatively charged marker molecule Lucifer yellow (LY, diameter $\sim 1 \mathrm{~nm}$, yellow circles); positively charged rhodamine 123 (R123, diameter $\sim 1 \mathrm{~nm}$, red circles) and neutral FITC-dextran $10 \mathrm{kDa}$ (FD, diameter $\sim 4 \mathrm{~nm}$, green circles) are indicated. Luminal surface charge is marked by blue lines: indicating negative charge and red crosses: positive charge caused by the insertion of lidocaine; Small dots: $\mathrm{Na}^{+}$ions, diameter $\sim 0.2 \mathrm{~nm}$; Light blue transporter: P-glycoprotein effux pump on the luminal side. Intercellular junctions between the cells (paracellular space) are marked by grey. 
This can be explained by the weaker barrier properties and the more dominant paracellular pathway on the hCMEC/D3 cell line as compared to BBB models based on primary cells (Helms et al., 2016; Veszelka et al., 2018). The leakier paracellular pathway was also confirmed by the TEER data (Figure 19A). In the case of the primary brain EC co-culture model, where TJs are tighter and the paracellular pathway is more closed, as reflected by the several fold higher TEER, the permeability of the cationic R123 was decreased by the positively charged lidocaine (Figure 19D). This can mean that a physicochemical interaction between lidocaine and R123 might occur. The two positively charged molecules interact at the surface of brain ECs and the transcellular permeability of R123 in the luminal to abluminal direction decreases (Figure 32). As shown previously by Suzuki et al. (2002, 2010), lidocaine decreased the permeability for the cationic drugs pentazocine and naloxone across the BBB in rats, which supports the findings of the present study. However, the possibility that other mechanisms than membrane interactions also participate in the effect of lidocaine on BBB permeability cannot be excluded. R123 is also a substrate of the Pgp efflux pump (Nakagawa et al., 2009), one of the most important efflux transporters at the BBB (Deli, 2011; Helms et al., 2016), therefore the effect of lidocaine on Pgp activity was also investigated. The effect of lidocaine was opposite to that of cyclosporine A, used as a reference Pgp inhibitor, suggesting that it does not inhibit the Pgp efflux pump (Figure 20). These results are in agreement with the previous findings showing that inhibition of Pgp did not change brain or plasma concentrations of lidocaine in rats (Funao et al., 2003) indicating that lidocaine does not interact with this efflux pump. Our observations on one hand can help to understand the biophysical background of lidocaine action, on the other hand draw attention to the drug interactions at the level of the BBB.

\subsection{Fluid flow makes brain endothelial surface charge more negative and promotes}

\section{glycocalyx expression on the human BBB model in the lab-on-a-chip device}

The BBB is composed of brain ECs that have strong interaction with the neighboring pericytes and astroglia end feet. Brain pericytes share a common basal membrane with the ECs and they have an important role in the development, maintenance, and regulation of BBB functions (Sweeney et al., 2019). It is known that the co-culture of brain ECs with PCs elevates the tightness of the paracellular barrier and increases BBB properties (Nakagawa et al., 2009; Cecchelli et al., 2014; Thomsen, et al., 2015), which was also observed in the present study (Figure 10). The human BBB model 
used here is stem cell based, where ECs derive from hematopoietic stem cells and are cocultured with bovine brain pericytes to induce brain EC-like characteristics. This is a well characterized in vitro model (Cecchelli et al., 2014; Mossu et al., 2019; Heymans et al., 2020), however no long-term (24-hour) fluid flow in a LOC device or the effect of dynamic conditions on this model have been investigated until now. It is important to note, that the shear stress applied in our study is lower $\left(0.4 \mathrm{dyne} / \mathrm{cm}^{2}\right)$ than what is calculated for brain capillaries in vivo (Cucullo et al., 2013), which is a limitation to our study. Nevertheless, the results presented here are of high importance in the understanding how the barrier integrity, ESG morphology and gene expression changes after fluid flow in this human BBB model. Even though the shear stress is low, by exerting the mechanical stimulus, it has more similarity to in vivo conditions in comparison with the static cell culture inserts. These observations help to characterize the human co-culture model for further use in experiments related to BBB pathology and pharmacology.

First, the barrier properties of the BLEC model were measured in the LOC device. After introducing fluid flow, TEER values significantly increased and permeability of the brain EC monolayers significantly decreased for both LY and EBA markers (Figure 22). As described in the results section 3.1., the permeability of the hCMEC/D3 and RBEC models in the LOC device was lower compared to the human co-culture model in the LOC device (Figure 10). Similar changes were found in previous studies using human BBB culture models in LOC devices (Cucullo et al., 2011; Walter et al., 2016). In contrast to the dynamic in vitro system using hollow fiber cartridges (Cucullo et al., 2011) the LOC device of the present study (Walter et al., 2016) allowed the morphological observation of BLECs, which showed similar immunostaining of junctional proteins as in the culture insert models in our experiments (Figure 23) and in the literature (Cecchelli et al., 2014; Mossu et al., 2019). Fluid flow changed cell shape to be more elongated and also realigned the cells in the direction of flow (Figure 22C), in accordance with a previous study on bovine brain ECs (Colgan et al., 2007). These observations prove that the LOC device is functional and show the importance of fluid flow in barrier integrity of the human BBB model (Cucullo et al., 2011; Walter et al., 2016).

Blood flow in capillaries and the resulting shear force are important physiological regulators of EC functions in the periphery (Fu and Tarbell, 2013) and in the brain (Sweeney et al., 2019). Flow-mediated regulation of endothelial genes has been studied on vascular ECs since a long time. Upregulation of genes TGF- $\beta$, EDN1/ET-1, CCL2/MCP-1 and ICAM-1 has been described previously (Ando and Kamiya, 1996) and 
was also confirmed in the present study. The observed changes in the human BBB model are complex: while expression level of the vasoconstrictor EDN-1 gene was increased, the level of one of its receptor gene, EDNRB, was decreased, and the vasodilating factor NOSIP, which interacts with NOS3, was found to be significantly upregulated. VEGFR1, upregulated under fluid flow in our model, mediates endothelial cytoprotection via serine/threonine-specific protein kinase AKT/protein kinase B (Dragoni and Turowski, 2018). LYVE1, a marker for peripheral ECs (Vanlandewijck et al., 2018) was differentially downregulated under flow in BLECs. Among EC surface adhesion molecules, fluid flow elevated the expression of ICAM1 gene, as described in the case of vascular ECs (Ando and Kamiya, 1996) and a human BBB model (Cucullo et al., 2011). This upregulation can be important for immune cell transmigration studies (Mossu et al., 2019). The expression of L-selectin gene SELL, which is present in some populations of peripheral EC but not in cerebral endothelium (Vanlandewijck et al., 2018) was decreased on BLECs under flow.

ECs respond to fluid flow by changing their morphology to a more elongated shape and align with the flow direction (Zeng et al., 2018). In the present study the morphological findings on the human BBB model in the LOC device are in accordance with these observations (Figure 22C and 23). This is further supported by the upregulation of cytoskeletal gene ACTN1, which is known to interact with NOS3 and TAGLN, crosslinking actin filaments and participating in cytoskeletal reorganization. Fluid flow is also known to increase the adhesion of ECs to the basal membrane via integrins which interact with collagen, laminin, and fibronectin (Reitsma et al., 2007). We found that several integrin- $\alpha$ subunit genes (ITGA5, -11, -E, -V) were significantly increased in dynamic conditions, while integrin- $\beta$ subunits were unchanged or downregulated. In a human EC and astrocyte co-culture model an increase in the gene expression for both $\alpha$ and $\beta$ integrin subunits was observed after flow (Cucullo et al., 2011), which may indicate a special role for astrocytes in the induction of these genes. In this study the differentially expressed basal membrane genes COL4A1, FBLN5 and the fibronectin related FNDC3B together with integrins may indicate a stronger attachment of the cells in dynamic conditions. MMPs are important in different physiological and pathological processes at the BBB. In cerebral ischemia MMPs participate both in the vascular injury and the repair phase during angiogenesis and reestablishment of blood flow (Rempe et al., 2016). In the present study several MMPs were differentially expressed, and their upregulation may be related with basal membrane remodeling induced by flow. 
The paracellular tightness of the BBB is controlled by transmembrane TJ proteins. Epithelial claudins CLDN1, -3, -7 were downregulated after BLEC were cultured under flow conditions. These claudins were also expressed at a low level in static cell culture insert-based BBB culture models (Veszelka et al., 2018) and in isolated brain ECs (Daneman et al., 2010; Vanlandewijck et al., 2018). Flow conditions did not change the expression level of important TJ genes such as ESAM, OCLDN, JAMs, MARVELDs and linkers TJPs. The expression level of claudin-5 gene, considered as the most important claudin in brain ECs, was decreased by flow in our co-culture model with PCs. This was not observed in the astrocyte co-culture model (Cucullo et al., 2011). In contrast, the genes of adherens junction proteins were either unchanged or upregulated together with gap junction genes. These, together with the unchanged level of several TJ genes, and increased level of basal membrane protein and integrins, might explain the observed increased barrier integrity of the BBB model. Functional measurements, namely TEER and permeability for molecular markers confirmed our findings.

The chemical protection of the CNS is maintained by active efflux pumps, mainly ABC transporters. The gene expression level for these transporters were mostly unchanged under dynamic conditions. Enzymes participating in drug metabolism were more sensitive to the effect of flow. Their level was unchanged or upregulated, like in the case of phase I enzymes CYP1A1 and CYP1B1, and phase II enzymes EPHX1 and GSTP1. The upregulation of P450 enzymes in a human BBB model by fluid flow was also described by Cucullo et al. (2011). The increased gene expression level of phase II enzymes EPHX1 and GSTP1 in brain ECs was also observed after co-culture with PCs in the same BLEC model (Heymans et al., 2020).

SLC transporters are key for the proper transport of nutrients to the CNS (CamposBedolla et al., 2014). The expression level of SLC transporters was either unchanged or in many cases increased under the dynamic conditions. In addition to nutrients, the BBB regulates the transport of ions through SLCs. On the human BBB model flow increased the gene expression of anion exchanger AE2 and the $\mathrm{K}^{+}-\mathrm{Cl}^{-}$cotransporter $(\mathrm{KCC} 1)$, while the expression level of voltage dependent $\mathrm{Ca}^{2+}$ (CACN family) and anion (VDAC) channels was unchanged. Several $\mathrm{K}^{+}$channels were found downregulated, which were also expressed at a very low level in isolated brain capillary ECs (Vanlandewijck et al., 2018). In the human BBB co-culture model with astrocytes an upregulation of $\mathrm{Ca}^{2+}$ and $\mathrm{K}^{+}$channels was observed under dynamic conditions (Cucullo et al., 2011) indicating an important role of co-culture conditions in the expression of these channels. 
Many important proteins and peptides, like insulin and holotransferrin, cross the BBB by receptor-mediated pathway (Abbott et al., 2006; Sweeney et al., 2019). Flow conditions did not change the expression level of many of these receptors. One of the exceptions is the elevation of the gene coding LRP5, a canonical WNT pathway signaling co-receptor, which participates in barrier genesis and BBB maturation (Sweeney et al., 2019). Flow downregulated the expression level of caveolin-1 gene. Since isolated brain ECs express much less CAV1 than peripheral (lung) ECs (Vanlandewijck et al., 2018), these changes may point to barrier maturation in the present model.

Continuous blood flow regulates the composition of ESG by the dynamic equilibrium of glycoproteins, proteoglycans, glycosaminoglycans and the associated plasma proteins (Reitsma et al., 2007). ESG is not only important as an element of the physical barrier (Kutuzov et al., 2018) with its highly negative charge but also control the stability of ECs. We observed the differential upregulation of major glycocalyx core protein genes DCN, SDC2 and VCAN, as well as the increase of GPC1 expression. The latter acts as mechano-sensor and also links the ESG to the cytoskeleton, therefore actively participates in flow induced morphological changes in ECs (Fu and Tarbell, 2013). An increased gene expression level for glycocalyx-related enzymes was observed. Heparanase and hyaluronidase-2, as well as carbohydrate sulfotransferase-1 and the heparan sulfate 6-O-endosulfatase, which adds and removes sulfate groups, are important for the overall negative charge of the glycocalyx. It may indicate active remodeling of the ESG under dynamic conditions. Direct measurement of the surface charge of the ECs by laser Doppler velocimetry confirmed that cells became more negatively charged (Figure 29A). These data together with increased WGA lectin staining (Figure 29B-C) support that the ESG of the human BBB model became more robust. These observations are further corroborated by the fact that the three most enriched pathways in the human BBB model after flow (Figure 30) were related to extracellular matrix organization, extracellular matrix structure organization and collagen-containing extracellular matrix. In addition, several other pathways related to cell surface, such as extracellular matrix proteoglycan and dermatan sulfate biosynthesis and metabolism were also increased. 


\section{Conclusion}

In the studies related to the present thesis we examined an important, but neglected area of BBB research, the surface charge of brain endothelial cells and its potential role in the transfer and interaction of lipophilic and cationic drug molecules at the BBB. As models we used state-of-the-art in vitro systems: a primary cell based complex one based on the co-culture of three cell types and two human models, one simplified cell line model and a novel stem cell-based co-culture. We compared their properties using two setups, cell culture inserts and an LOC device developed by our laboratory in cooperation with the Biomolecular Electronics Research Group of the BRC. We demonstrated that the morphological and functional features of the BBB models were similar in the inserts and the LOC devices, except for the stem cell derived human BBB models, which showed more physiological properties and indicates that LOC devices must be important in the development of better in vitro human BBB models.

We revealed that brain ECs in all models has a surface glycocalyx that can be visualized by lectin staining. With the laser Doppler velocimetry method established in our laboratory we could directly measure the zeta potential of brain endothelial ECs and compare the different BBB models. The cell line model and human ECs in mono-cultures showed less negative charge than BBB co-culture models highlighting the importance of the influence of pericytes and astrocytes. Since several pathologies like diabetes, sepsis, hypertension, and infections promote glycocalyx damage, this method and the new human co-culture BBB model can be valuable tools to study BBB glycocalyx and related surface charge changes.

An important part of our studies focused on the effects of brain endothelial surface charge modulation. Using the hCMEC/D3 cell line as a simplified BBB model and the primary co-culture BBB model we tested two methods: treatment of the cells with neuraminidase, an enzyme cleaving the sialic acids of the surface glycocalyx, or with lidocaine, a drug that intercalates with the plasma membrane. Though neuraminidase effectively removed the sialic acid residues of the endothelial glycocalyx and made the zeta potential of brain endothelial ECs more positive, it did not change the barrier integrity of neither of the BBB models. Further studies would be needed to reveal the differences between peripheral and CNS endothelial cells for their sensitivity to glycocalyx damage and its consequences on endothelial barrier function. Lidocaine increased the ionic permeability of BBB models, but the paracellular pathway passage was not altered for water-soluble marker molecules. In contrast, the permeability of a cationic lipophilic 
marker was decreased, suggesting interaction of the cationic molecules at the membrane level. Lidocaine had no effect on the function of the Pgp efflux pump. Our observations draw the attention to the drug interactions at the level of the BBB after modulation of the brain endothelial charge.

The introduction of human stem cells to establish in vitro BBB models is considered as a breakthrough technology. In contrast to previous BBB models stem cells allow the development of patient-specific models. While other stem cell BBB models were tested in microfluidic devices, the BLEC model has only be investigated mainly in culture inserts. Our study is the first to test the effects of fluid flow on this human stem cell based BBB co-culture model in a microelectronic LOC device. We demonstrated that flow increased barrier properties, induced several key general endothelial and BBBrelated genes on BLECs. In addition, flow condition not only upregulated extracellular matrix and glycocalyx-related genes and pathways but made the brain EC surface more negatively charged and richer in lectin binding sites. These results draw the attention to the importance of the use of flow in BBB culture models and the endothelial surface glycocalyx as a defense element of the BBB. Our data contribute to the better characterization of this human co-culture BBB model that can be a novel tool not only to study BBB physiology and pathology but also to examine cell surface glycocalyx at the BBB. Our experiments provided new comparative data on BBB culture models in both inserts and LOC devices and highlighted the importance of brain endothelial surface charge and glycocalyx in BBB functions.

The surface glycocalyx of vascular endothelial cells is modified in pathological conditions, in which shedding of glycocalyx components was described. Although there are multiple investigations about this phenomenon in peripheral endothelial cells, the surface charge and glycocalyx composition at the BBB in CNS related diseases are not explored in depth. The new LOC device is a unique tool to study BBB models due to the applied shear stress and combination of visualization and barrier integrity measurements. Our work proved that surface charge and glycocalyx are important parameters to measure in BBB models and the LOC device will help to study these parameters in pathological conditions. In the future we aim to model the BBB in disease conditions and study glycocalyx shedding and surface charge changes of brain endothelial cells. 


\section{Acknowledgements}

First of all, I want to thank to my supervisor Prof. Mária Deli. I appreciate all the support, understanding, teaching, criticism, and opportunities she gave to me. Making possible to travel to other countries, learning a wide variety of techniques contributed to my development as a scientist.

Secondly, I want to thank to my co-supervisor Dr. Fruzsina Walter for her confidence in me, support, commitment, and friendship especially during the last two years. Thank you for your encouragement in the difficult moments and to be always there for me. Thank you from the heart.

I would also like to thank Prof. András Dér for all the support, criticism, ideas, sympathy and for the words of encouragement. I also thank to the members of his group, András Kincses and Dr. Sándor Valkai for their technical and scientific help.

I would also like to thank to Dr. Mária Mészáros, Dr. András Harazin, Dr. Szilvia Veszelka, Dr. Zsófia Hoyk, Dr. Alexandra Bocsik, Judit Vigh, Ilona Gróf, Beáta Barabási, Lilla Barna, Gergő Porkoláb, Dóra Lipka, Adrián Klepe, Daniel Galvis, Afnan Al Doghmi and Zsuzsanna Szabó for all the support and companionship in the lab.

I am grateful for the support and help of Prof. László Zimányi and the colleagues at the Institute of Biophysics of the BRC.

To the BtRAIN network, for the partnership, the travels together, the conferences, the infinite conversations on the WhatsApp. It was a pleasure sharing this journey with you.

To my friends in Portugal I would not made it without you. The videocalls until late, the constant messages, the friendship, and the support that I could do it.

A very special thanks to the friends I made here: Dr. Ana Martins and Dr. Attila Hunyadi, without you it would have been "mission impossible"! With you I cried, I laughed, I wanted to give up and continue, but you were always there for me in all of these moments. This thesis is also yours! Thank you very much for your support. Dr. André Meireles, Dr. Claúdia Fitas, Dr. Romy Moukhaiber, Rita Brás you made my journey much easier I appreciate all the dedication, support and especially your confidence in me, that I could do it.

To my fiancé for all the long conversations about the blood-brain barrier, for all the nights without sleep, for all the support, and especially for being always there for me. You make this journey easier, and this thesis is also yours! Thank you very much!

Por fim, a minha família, a minha mãe, meu pai, meu irmão, avós, tios e primos, obrigada por todo o apoio, amor, afeto, e por acreditarem que eu conseguiria chegar ao final. Este trabalho foi feito com muita dedicação, esforço, e sobretudo comprometimento da minha parte. Mas isto não teria sido a mesma coisa sem o suporte incondicional dos meus pais. Obrigada mãe e obrigada pai!

Ao meu cão, Rocky Balboa, por estar sempre ao pé de mim em qualquer momento, por as longas caminhadas, por seres a minha companhia em tantos momentos, e por nunca me teres abandonado.

For all the past and future opportunities I am grateful from my heart!

"Have the courage to follow your heart and intuition. They somehow already know what you truly want to become." By Steve Jobs 


\section{References}

Abbott NJ, Patabendige AA, Dolman DE, Yusof SR, Begley DJ. Structure and function of the blood-brain barrier. Neurobiol Dis. 2010 Jan;37(1):13-25.

Abbott NJ, Rönnbäck L, Hansson E. Astrocyte-endothelial interactions at the blood-brain barrier. Nat Rev Neurosci. 2006 Jan;7(1):41-53.

Ando J, Kamiya A. Flow-dependent regulation of gene expression in vascular endothelial cells. Jpn Heart J. 1996 Jan;37(1):19-32.

Ando Y, Okada H, Takemura G, Suzuki K, Takada C, Tomita H, Zaikokuji R, Hotta Y, Miyazaki N, Yano H, Muraki I, Kuroda A, Fukuda H, Kawasaki Y, Okamoto H, Kawaguchi T, Watanabe T, Doi T, Yoshida T, Ushikoshi H, Yoshida S, Ogura S. Brain-Specific Ultrastructure of Capillary Endothelial Glycocalyx and Its Possible Contribution for Blood Brain Barrier. Sci Rep. 2018 Nov 30;8(1):17523.

Appelt-Menzel A, Oerter S, Mathew S, Haferkamp U, Hartmann C, Jung M, Neuhaus W, Pless O. Human iPSC-Derived Blood-Brain Barrier Models: Valuable Tools for Preclinical Drug Discovery and Development? Curr Protoc Stem Cell Biol. 2020 Dec;55(1):e122.

Avdeef A, Deli MA, Neuhaus W. In vitro assays for assessing BBB permeability: artificial membrane and cell culture models. In: Di L, Kerns EH (ed.); Blood-brain barrier in drug discovery: optimizing brain exposure of drugs and minimizing brain side effects. Hoboken: John Wiley and Sons, Inc., 2015. pp. 188-237.

Baughman VL, Laurito CE, Polek WV. Lidocaine blood levels following aerosolization and intravenous administration. J Clin Anesth. 1992 Jul-Aug;4(4):325-7.

Bell AH, Miller SL, Castillo-Melendez M, Malhotra A. The Neurovascular Unit: Effects of Brain Insults During the Perinatal Period. Front Neurosci. 2020 Jan 22;13:1452.

Benson K, Cramer S, Galla HJ. Impedance-based cell monitoring: barrier properties and beyond. Fluids Barriers CNS. 2013 Jan 10;10(1):5.

Betteridge KB, Arkill KP, Neal CR, Harper SJ, Foster RR, Satchell SC, Bates DO, Salmon AHJ. Sialic acids regulate microvessel permeability, revealed by novel in vivo studies of endothelial glycocalyx structure and function. J Physiol. 2017 Aug 1;595(15):5015-5035.

Blanchette M, Daneman R. Formation and maintenance of the BBB. Mech Dev. 2015 Nov;138 Pt 1:8-16.

Bocsik A, Walter FR, Gyebrovszki A, Fülöp L, Blasig I, Dabrowski S, Ötvös F, Tóth A, Rákhely G, Veszelka S, Vastag M, Szabó-Révész P, Deli MA. Reversible Opening of Intercellular Junctions of Intestinal Epithelial and Brain Endothelial Cells With Tight Junction Modulator Peptides. J Pharm Sci. 2016 Feb;105(2):754-765.

Booth R, Kim H. Characterization of a microfluidic in vitro model of the blood-brain barrier ( $\mu$ BBB). Lab Chip. 2012 Apr 24;12(10):1784-92.

Brunton L, Chabner B, K. B. The Pharmaceutical Basis of Therapeutics. Goodman and Gillman's twelth edition. Edited by M. H. Medical. New York, NY. 2011;

Campbell SD, Regina KJ, Kharasch ED. Significance of lipid composition in a bloodbrain barrier-mimetic PAMPA assay. J Biomol Screen. 2014 Mar;19(3):437-44.

Campos-Bedolla P, Walter FR, Veszelka S, Deli MA. Role of the blood-brain barrier in 
the nutrition of the central nervous system. Arch Med Res. 2014 Nov;45(8):610-38.

Cecchelli R, Aday S, Sevin E, Almeida C, Culot M, Dehouck L, Coisne C, Engelhardt B, Dehouck MP, Ferreira L. A stable and reproducible human blood-brain barrier model derived from hematopoietic stem cells. PLoS One. 2014 Jun 17;9(6):e99733.

Colgan OC, Ferguson G, Collins NT, Murphy RP, Meade G, Cahill PA, Cummins PM. Regulation of bovine brain microvascular endothelial tight junction assembly and barrier function by laminar shear stress. Am J Physiol Heart Circ Physiol. 2007 Jun;292(6):H3190-7.

Cucullo L, Hossain M, Puvenna V, Marchi N, Janigro D. The role of shear stress in BloodBrain Barrier endothelial physiology. BMC Neurosci. 2011 May 11;12:40.

Cucullo L, Hossain M, Tierney W, Janigro D. A new dynamic in vitro modular capillaries-venules modular system: cerebrovascular physiology in a box. BMC Neurosci. 2013 Feb 6;14:18.

Dan GA, Martinez-Rubio A, Agewall S, Boriani G, Borggrefe M, Gaita F, van Gelder I, Gorenek B, Kaski JC, Kjeldsen K, Lip GYH, Merkely B, Okumura K, Piccini JP, Potpara T, Poulsen BK, Saba M, Savelieva I, Tamargo JL, Wolpert C; ESC Scientific Document Group. Antiarrhythmic drugs-clinical use and clinical decision making: a consensus document from the European Heart Rhythm Association (EHRA) and European Society of Cardiology (ESC) Working Group on Cardiovascular Pharmacology, endorsed by the Heart Rhythm Society (HRS), AsiaPacific Heart Rhythm Society (APHRS) and International Society of Cardiovascular Pharmacotherapy (ISCP). Europace. 2018 May 1;20(5):731-732an.

Daneman R, Prat A. The blood-brain barrier. Cold Spring Harb Perspect Biol. 2015 Jan 5;7(1):a020412.

Daneman R, Zhou L, Agalliu D, Cahoy JD, Kaushal A, Barres BA. The mouse bloodbrain barrier transcriptome: a new resource for understanding the development and function of brain endothelial cells. PLoS One. 2010 Oct 29;5(10):e13741.

Daykin $\mathrm{H}$. The efficacy and safety of intravenous lidocaine for analgesia in the older adult: a literature review. Br J Pain. 2017 Feb;11(1):23-31.

Deli MA, Abrahám CS, Kataoka Y, Niwa M. Permeability studies on in vitro blood-brain barrier models: physiology, pathology, and pharmacology. Cell Mol Neurobiol. $2005 \mathrm{Feb} ; 25(1): 59-127$.

Deli MA. Drug transport and the blood-brain barrier.Solubility, Delivery, and ADME Problems of Drugs and Drug-Candidates. Washington: Bentham Science Publishers Ltd 2011: 144-165.

Deli MA. Potential use of tight junction modulators to reversibly open membranous barriers and improve drug delivery. Biochim Biophys Acta. 2009 Apr;1788(4):892910.

Delsing L, Herland A, Falk A, Hicks R, Synnergren J, Zetterberg H. Models of the bloodbrain barrier using iPSC-derived cells. Mol Cell Neurosci. 2020 Sep;107:103533.

Dogné S, Flamion B. Endothelial Glycocalyx Impairment in Disease: Focus on Hyaluronan Shedding. Am J Pathol. 2020 Apr;190(4):768-780.

Domingues MM, Santiago PS, Castanho MA, Santos NC. What can light scattering 
spectroscopy do for membrane-active peptide studies? J Pept Sci. 2008 Apr;14(4):394-400.

Dragoni S, Turowski P. Polarised VEGFA Signalling at Vascular Blood-Neural Barriers. Int J Mol Sci. 2018 May 5;19(5):1378.

Edgar R, Domrachev M, Lash AE. Gene Expression Omnibus: NCBI gene expression and hybridization array data repository. Nucleic Acids Res. 2002 Jan 1;30(1):20710.

$\mathrm{Fu} \mathrm{BM}$, Tarbell JM. Mechano-sensing and transduction by endothelial surface glycocalyx: composition, structure, and function. Wiley Interdiscip Rev Syst Biol Med. 2013 May-Jun;5(3):381-90.

Funao T, Oda Y, Tanaka K, Asada A.The P-glycoprotein inhibitor quinidine decreases the threshold for bupivacaine-induced, but not lidocaine-induced, convulsions in rats. Canadian Journal of Anesthesia 2003, 50(8), 805.

Helms HC, Abbott NJ, Burek M, Cecchelli R, Couraud PO, Deli MA, Förster C, Galla HJ, Romero IA, Shusta EV, Stebbins MJ, Vandenhaute E, Weksler B, Brodin B. In vitro models of the blood-brain barrier: An overview of commonly used brain endothelial cell culture models and guidelines for their use. J Cereb Blood Flow Metab. 2016 May;36(5):862-90.

Herland A, van der Meer AD, FitzGerald EA, Park TE, Sleeboom JJ, Ingber DE. Distinct Contributions of Astrocytes and Pericytes to Neuroinflammation Identified in a 3D Human Blood-Brain Barrier on a Chip. PLoS One. 2016 Mar 1;11(3):e0150360.

Hervé F, Ghinea N, Scherrmann JM. CNS delivery via adsorptive transcytosis. AAPS J. 2008 Sep;10(3):455-72.

Heymans M, Figueiredo R, Dehouck L, Francisco D, Sano Y, Shimizu F, Kanda T, Bruggmann R, Engelhardt B, Winter P, Gosselet F, Culot M. Contribution of brain pericytes in blood-brain barrier formation and maintenance: a transcriptomic study of cocultured human endothelial cells derived from hematopoietic stem cells. Fluids Barriers CNS. 2020 Jul 28;17(1):48.

Högberg CJ, Lyubartsev AP. Effect of local anesthetic lidocaine on electrostatic properties of a lipid bilayer. Biophys J. 2008 Jan 15;94(2):525-31.

Kutuzov N, Flyvbjerg H, Lauritzen M. Contributions of the glycocalyx, endothelium, and extravascular compartment to the blood-brain barrier. Proc Natl Acad Sci U S A. 2018 Oct 2;115(40):E9429-E9438.

Lénárt N, Walter FR, Bocsik A, Sántha P, Tóth ME, Harazin A, Tóth AE, Vizler C, Török Z, Pilbat AM, Vígh L, Puskás LG, Sántha M, Deli MA. Cultured cells of the bloodbrain barrier from apolipoprotein B-100 transgenic mice: effects of oxidized lowdensity lipoprotein treatment. Fluids Barriers CNS. 2015 Jul 17;12:17.

Li G, Fu BM. An electrodiffusion model for the blood-brain barrier permeability to charged molecules. J Biomech Eng. 2011 Feb;133(2):021002.

Lippmann ES, Azarin SM, Kay JE, Nessler RA, Wilson HK, Al-Ahmad A, Palecek SP, Shusta EV. Derivation of blood-brain barrier endothelial cells from human pluripotent stem cells. Nat Biotechnol. 2012 Aug;30(8):783-91.

Lippmann ES, Azarin SM, Palecek SP, Shusta EV. Commentary on human pluripotent stem cell-based blood-brain barrier models. Fluids Barriers CNS. 2020 Oct 
19;17(1):64.

Love MI, Huber W, Anders S. Moderated estimation of fold change and dispersion for RNA-seq data with DESeq2. Genome Biol. 2014;15(12):550.

Lu TM, Redmond D, Magdeldin T, Nguyen DHT, Snead A, Sproul A, Xiang J, Shido K, Fine HA, Rosenwaks Z, Rafii S, Agalliu D, Lis R. Human induced pluripotent stem cell-derived neuroectodermal epithelial cells mistaken for blood-brain barrierforming endothelial cells. bioRxiv 699173. Jul 2019.

Maoz BM, Herland A, FitzGerald EA, Grevesse T, Vidoudez C, Pacheco AR, Sheehy SP, Park TE, Dauth S, Mannix R, Budnik N, Shores K, Cho A, Nawroth JC, Segrè D, Budnik B, Ingber DE, Parker KK. A linked organ-on-chip model of the human neurovascular unit reveals the metabolic coupling of endothelial and neuronal cells. Nat Biotechnol. 2018 Oct;36(9):865-874.

Mészáros M, Porkoláb G, Kiss L, Pilbat AM, Kóta Z, Kupihár Z, Kéri A, Galbács G, Siklós L, Tóth A, Fülöp L, Csete M, Sipos Á, Hülper P, Sipos P, Páli T, Rákhely G, Szabó-Révész P, Deli MA, Veszelka S. Niosomes decorated with dual ligands targeting brain endothelial transporters increase cargo penetration across the bloodbrain barrier. Eur J Pharm Sci. 2018 Oct 15;123:228-240.

Mossu A, Rosito M, Khire T, Li Chung H, Nishihara H, Gruber I, Luke E, Dehouck L, Sallusto F, Gosselet F, McGrath JL, Engelhardt B. A silicon nanomembrane platform for the visualization of immune cell trafficking across the human bloodbrain barrier under flow. J Cereb Blood Flow Metab. 2019 Mar;39(3):395-410.

Nakagawa S, Deli MA, Kawaguchi H, Shimizudani T, Shimono T, Kittel A, Tanaka K, Niwa M. A new blood-brain barrier model using primary rat brain endothelial cells, pericytes and astrocytes. Neurochem Int. 2009 Mar-Apr;54(3-4):253-63.

Obermeier B, Daneman R, Ransohoff RM. Development, maintenance and disruption of the blood-brain barrier. Nat Med. 2013 Dec;19(12):1584-96.

Ohtsuki S, Hirayama M, Ito S, Uchida Y, Tachikawa M, Terasaki T. Quantitative targeted proteomics for understanding the blood-brain barrier: towards pharmacoproteomics. Expert Rev Proteomics. 2014 Jun;11(3):303-13.

Pedroso DC, Tellechea A, Moura L, Fidalgo-Carvalho I, Duarte J, Carvalho E, Ferreira L. Improved survival, vascular differentiation and wound healing potential of stem cells co-cultured with endothelial cells. PLoS One. 2011 Jan 24;6(1):e16114.

Perrière N, Demeuse P, Garcia E, Regina A, Debray M, Andreux JP, Couvreur P, Scherrmann JM, Temsamani J, Couraud PO, Deli MA, Roux F. Puromycin-based purification of rat brain capillary endothelial cell cultures. Effect on the expression of blood-brain barrier-specific properties. J Neurochem. 2005 Apr;93(2):279-89.

Reitsma S, Slaaf DW, Vink H, van Zandvoort MA, oude Egbrink MG. The endothelial glycocalyx: composition, functions, and visualization. Pflugers Arch. 2007 Jun;454(3):345-59.

Rempe RG, Hartz AMS, Bauer B. Matrix metalloproteinases in the brain and blood-brain barrier: Versatile breakers and makers. J Cereb Blood Flow Metab. 2016 Sep;36(9):1481-507.

Ribeiro MM, Domingues MM, Freire JM, Santos NC, Castanho MA. Translocating the blood-brain barrier using electrostatics. Front Cell Neurosci. 2012 Oct 11;6:44. 
Ribeiro MM, Pinto AR, Domingues MM, Serrano I, Heras M, Bardaji ER, Tavares I, Castanho MA. Chemical conjugation of the neuropeptide kyotorphin and ibuprofen enhances brain targeting and analgesia. Mol Pharm. 2011 Oct 3;8(5):1929-40.

Seeman P. The membrane actions of anesthetics and tranquilizers. Pharmacol Rev. 1972 Dec;24(4):583-655.

Sheetz MP, Singer SJ. Biological membranes as bilayer couples. A molecular mechanism of drug-erythrocyte interactions. Proc Natl Acad Sci U S A. 1974 Nov;71(11):445761.

Singh A, Satchell SC, Neal CR, McKenzie EA, Tooke JE, Mathieson PW. Glomerular endothelial glycocalyx constitutes a barrier to protein permeability. J Am Soc Nephrol. 2007 Nov;18(11):2885-93.

Suzuki T, Miyata M, Zaima C, Furuishi T, Fukami T, Kugawa F, Tomono K. Blood-brain barrier transport of naloxone does not involve P-glycoprotein-mediated efflux. J Pharm Sci. 2010 Jan;99(1):413-21.

Suzuki T, Moriki Y, Goto H, Tomono K, Hanano M, Watanabe J. Investigation on the influx transport mechanism of pentazocine at the blood-brain barrier in rats using the carotid injection technique. Biol Pharm Bull. 2002 Oct;25(10):1351-5.

Sweeney MD, Ayyadurai S, Zlokovic BV. Pericytes of the neurovascular unit: key functions and signaling pathways. Nat Neurosci. 2016 May 26;19(6):771-83.

Sweeney MD, Zhao Z, Montagne A, Nelson AR, Zlokovic BV. Blood-Brain Barrier: From Physiology to Disease and Back. Physiol Rev. 2019 Jan 1;99(1):21-78.

Tewes BJ, Galla HJ. Lipid polarity in brain capillary endothelial cells. Endothelium. 2001;8(3):207-20.

Thomsen LB, Burkhart A, Moos T. A Triple Culture Model of the Blood-Brain Barrier Using Porcine Brain Endothelial cells, Astrocytes and Pericytes. PLoS One. 2015 Aug 4;10(8):e0134765.

Tsuchiya H, Mizogami M. Interaction of local anesthetics with biomembranes consisting of phospholipids and cholesterol: mechanistic and clinical implications for anesthetic and cardiotoxic effects. Anesthesiol Res Pract. 2013;2013:297141.

van den Berg, Nieuwdorp M, Stroes ES, Vink H. Glycocalyx and endothelial (dys) function: from mice to men. Pharmacol Rep. 2006;58 Suppl:75-80.

van der Helm MW, van der Meer AD, Eijkel JC, van den Berg A, Segerink LI. Microfluidic organ-on-chip technology for blood-brain barrier research. Tissue Barriers. 2016 Jan 28;4(1):e1142493.

Vanlandewijck M, He L, Mäe MA, Andrae J, Ando K, Del Gaudio F, Nahar K, Lebouvier T, Laviña B, Gouveia L, Sun Y, Raschperger E, Räsänen M, Zarb Y, Mochizuki N, Keller A, Lendahl U, Betsholtz C. A molecular atlas of cell types and zonation in the brain vasculature. Nature. 2018 Feb 22;554(7693):475-480.

Veszelka S, Ágnes K, Deli MA. Tools of modelling blood-brain barrier penetrability. Solubility, Delivery and ADME Problems of Drugs and DrugCandidates, Bentham Science Publishers, Washington 2011: 166-188.

Veszelka S, Tóth A, Walter FR, Tóth AE, Gróf I, Mészáros M, Bocsik A, Hellinger É, Vastag M, Rákhely G, Deli MA. Comparison of a Rat Primary Cell-Based BloodBrain Barrier Model With Epithelial and Brain Endothelial Cell Lines: Gene 
Expression and Drug Transport. Front Mol Neurosci. 2018 May 22;11:166.

Walter FR, Valkai S, Kincses A, Petneházi A, Czeller T, Veszelka S, Pál O, Deli MA, Dér A. A versatile lab-on-a-chip tool for modeling biological barriers. Sensors and Actuators B: Chemical 2016: 222, 1209-1219.

Walter FR, Veszelka S, Pásztói M, Péterfi ZA, Tóth A, Rákhely G, Cervenak L, Ábrahám CS, Deli MA. Tesmilifene modifies brain endothelial functions and opens the blood-brain/blood-glioma barrier. J Neurochem. 2015a Sep;134(6):1040-54.

Walter W, Sánchez-Cabo F, Ricote M. GOplot: an R package for visually combining expression data with functional analysis. Bioinformatics. 2015b Sep 1;31(17):29124.

Weizenmann N, Huster D, Scheidt HA. Interaction of local anesthetics with lipid bilayers investigated by ${ }^{1} \mathrm{H}$ MAS NMR spectroscopy. Biochim Biophys Acta. 2012 Dec;1818(12):3010-8.

Weksler B, Romero IA, Couraud PO. The hCMEC/D3 cell line as a model of the human blood brain barrier. Fluids Barriers CNS. 2013 Mar 26;10(1):16.

Weksler BB, Subileau EA, Perrière N, Charneau P, Holloway K, Leveque M, TricoireLeignel H, Nicotra A, Bourdoulous S, Turowski P, Male DK, Roux F, Greenwood J, Romero IA, Couraud PO. Blood-brain barrier-specific properties of a human adult brain endothelial cell line. FASEB J. 2005 Nov;19(13):1872-4.

Youdim KA, Avdeef A, Abbott NJ. In vitro trans-monolayer permeability calculations: often forgotten assumptions. Drug Discov Today. 2003 Nov 1;8(21):997-1003.

Yun I, Cho ES, Jang HO, Kim UK, Choi CH, Chung IK, Kim IS, Wood WG. Amphiphilic effects of local anesthetics on rotational mobility in neuronal and model membranes. Biochim Biophys Acta. 2002 Aug 19;1564(1):123-32.

Zeng Y, Zhang XF, Fu BM, Tarbell JM. The Role of Endothelial Surface Glycocalyx in Mechanosensing and Transduction. Adv Exp Med Biol. 2018;1097:1-27. 


\section{Summary}

The role of brain endothelial surface charge and glycocalyx in the function and integrity of the blood-brain barrier

The blood brain barrier (BBB) is a dynamic interface that separates the blood from the central nervous system (CNS). The microvessels that form the BBB are composed of brain endothelial cells (ECs) that exhibit special features and form a functional unit with the neighboring pericytes, astrocytes and neurons. The BBB is responsible for keeping the homeostasis of the CNS, providing nutrients for proper cellular functions and for the protection of the brain. These are regulated by the specific features of the brain ECs: by tight intercellular junctions, lack of fenestrae, low level of transcytosis and polarized influx and efflux transporters. Besides the efflux transport systems and tight junctions, the endothelial surface glycocalyx (ESG), composed of glycoproteins and proteoglycans, represent another important defense element of the BBB. This negatively charged sugarprotein matrix on the surface of the brain ECs together with the negatively charged plasma membrane phospholipids acts as a physical barrier for charged molecules, drugs and transmigrating cells. Despite of the potential importance of the negative surface charge in both physiology and pathology of the $\mathrm{BBB}$, this area is under researched.

To reach our main goal, to study how changes in surface charge may affect the functions of brain endothelial cells and BBB integrity we used cell culture models of the BBB. In vitro BBB models are important tools to study barrier functions, pathologies, microbe, cell and drug interactions. In this study we aimed to compare three of these BBB models: (i) our primary rat brain EC, pericyte and astrocyte co-culture model, (ii) the human hCMEC/D3 brain EC line, and (iii) a stem cell-derived human EC and bovine pericytes co-culture model. We wanted to compare the barrier integrity of these BBB models on cell culture inserts or in our patented lab-on-a-chip (LOC) device. We studied the integrity, the glycocalyx and surface charge of these BBB models in both setups. To investigate how the modulation of the glycocalyx with the neuraminidase enzyme or the membrane-intercalating lidocaine drug changes the surface charge and barrier integrity of brain ECs the rat co-culture model and the hCMEC/D3 cell line were used. Our further goal was to characterize the human brain like EC co-culture model under dynamic conditions for the first time by performing functional experiments and gene expression analysis. 
First, we investigated the barrier properties of the three BBB models on cell culture inserts or in the LOC device. We measured the transendothelial electrical resistance (TEER) and fluorescent marker permeability of the three different BBB models. The rat primary co-culture model was the tightest for ions on the cell culture inserts, but the BLEC co-culture had the highest TEER in the LOC device. The weakest barrier properties were measured in both setups on the hCMEC/D3 cell line, which showed the lowest TEER and the highest permeability values compared to other BBB models. We characterized the human EC mono- and pericytes co-culture models in a LOC device for the first time. These stem cell derived models showed an increased TEER and a decreased permeability in the LOC compared to culture inserts. ESG could be visualized by lectin staining in all the BBB models cultured on inserts which showed an inhomogeneous staining pattern with higher intensity around the cell nuclei. We investigated for the first time the effect of co-culture on the glycocalyx of the stem cellderived human EC model using the LOC device, where we found a stronger staining, indicating a denser ESG in this setup.

Our next goal was to directly measure and modulate the surface charge of brain ECs. We tested two approaches. We applied neuraminidase enzyme, which specifically removes sialic acid residues from the ESG and therefore makes the surface charge more positive. We also tested lidocaine, a lipophilic and cationic therapeutic drug, which intercalates to plasma membranes, to change the surface charge of BBB models and study its effects on barrier properties and the permeability of charged molecules. In these experiments we used the hCMEC/D3 cell line as a simplified BBB model and the rat primary cell based co-culture BBB model. We directly measured the surface charge of hCMEC/D3 cells and primary rat brain ECs by laser Doppler velocimetry and found it highly negative. We demonstrated that neuraminidase removed the amount of sialic acid residues on the glycocalyx and made the surface charge of brain ECs more positive. Cleavage of sialic acid residues from the ESG did not interfere with permeability for dextran and albumin on the BBB models. We revealed that lidocaine also changed the surface charge of brain ECs and made zeta potential values more positive in both BBB models. Lidocaine treatment slightly decreased the TEER of brain ECs suggesting an increased paracellular ionic permeability. However, there was no change in the permeability for negatively charged and hydrophilic markers Lucifer yellow and dextran during lidocaine treatment. This result indicates that lidocaine may affect the paracellular pathway for ions, but not for water-soluble molecules. In contrast, we found that the 
permeability of the cationic and lipophilic rhodamine 123 was decreased, suggesting an interaction of the cationic lidocaine and rhodamine at the plasma membrane of brain ECs. We also proved that this effect is not based on an interference with efflux pump activity.

Since the stem cell based human BBB co-culture model was only investigated under static conditions, we also aimed to test the effect of fluid flow in the LOC device on barrier integrity, surface charge and ESG of this model using both functional and transcriptomic assays. We could demonstrate that flow conditions increased barrier properties and induced several key general endothelial and BBB-related genes in brain ECs. In addition, flow conditions not only upregulated extracellular matrix and glycocalyx-related genes and pathways but turned the brain endothelial cell surface more negatively charged and richer in lectin binding sites.

In conclusion, based on our investigations we found the surface charge of rat and human brain ECs from three different BBB models highly negative, supporting a previous observation on bovine brain ECs. Moreover, we are the first to describe the modulation of the brain ESG using neuraminidase enzyme and the cationic lipophilic drug lidocaine and how that changes the barrier properties of different BBB models. Our data draw attention to the importance of the ESG as a physical barrier of the BBB and to the interaction of charged drugs at the level of BBB. The results obtained by the use of our LOC device strengthen the significance of using flow in BBB models. The human coculture BBB model can be a novel tool to study the role of cell surface glycocalyx in BBB physiology and pathology. The experimental data of our studies contribute to the knowledge about the surface charge and glycocalyx of brain ECs and the interaction of charged molecules at the $\mathrm{BBB}$, and highlight the importance of fluid flow generated shear stress in BBB modeling. 


\section{Összefoglaló}

\section{Az agyi endotélsejtek sejtfelszíni töltésének és glikokalix rétegének szerepe a vér-agy gát integritásában és működésében}

Az agyi kapilláris ereket alkotó belhámsejtek - az agyi endotélsejtek - az őket körülvevő asztroglia és pericita sejtekkel együtt biológiai gátrendszert hoznak létre, amelyet vér-agy gátnak nevezünk. A vér-agy gát a vérkeringés és a központi idegrendszer között dinamikus határfelületet alkot. A gátat alkotó agyi endortélsejtek müködése hozza létre és tartja fenn az idegrendszeri homeosztázist és táplálja az idegsejteket. Az agyi endotélsejtekre jellemző különleges tulajdonságok közé soroljuk az alábbiakat: a sejtek közötti szoros kapcsolatok, a nem-specifikus transzcitózis alacsony szintje, szállítófehérjék és efflux pumpák. Ezek teszik lehetővé a központi idegrendszer táplálását és védelmét a káros anyagok és a kórokozók ellen. Az efflux pumpák és szoros kapcsolatok mellett fontos fizikai védelmet biztosít a belhámsejtek felszínén megtalálható glikokalix, amelyet proteoglikánok és glikoproteinek hálózata alkot. A glikokalix a sejtmembránban található foszfolipid fejcsoportokkal együtt az agyi endotélsejtek felszínén negatív töltés réteget hoz létre, amely korlátozza és szabályozza töltéssel rendelkező molekulák, gyógyszerhatóanyagok vagy sejtek átjutását. A glikokalix szerepe élettani és kórélettani szempontból nagyon jelentős, ennek ellenére ez a terület egyelöre kevéssé kutatott.

Fő kutatási célunk az volt, hogy feltárjuk a felszíni töltés változásai hogyan befolyásolják az agyi endotélsejtek müködését és gátmüködését. Munkánkhoz sejttenyészetes modelleket használtunk. A vér-agy gát in vitro modelljei lehetővé teszik többek között a gát tulajdonságok, kórélettani folyamatok, és az agyi endotélsejt rétegen történő hatóanyag-átjutás, sejtek vagy mikróbákkal történő kölcsönhatások vizsgálatát. Kísérleteink során három sejttenyészetes vér-agy gát modellnek az összehasonlítását tüztük ki célul: (i) a laborunk által kifejlesztett primer patkány agyi endotélsejtek, periciták és asztrogliák együtt tenyésztésével létrehozott rendszernek, (ii) egy egyszerüsített modellnek, a humán hCMEC/D3 agyi endotél sejtvonalnak, és (iii) az őssejt-eredetű humán endotélsejt és agyi pericita ko-kultúrának. Elsőként szerettük volna kimutatni a modellek közötti különbségeket, jellemezni a gát tulajdonságokat sejttenyésztő betétek és az általunk szabadalmaztatott lab-on-a-chip eszköz segítségével. Emellett mindkét kísérletes elrendezésben tanulmányoztuk a vér-agy gát modellek glikokalix rétegét és sejtfelszíni töltését. Annak feltárására, hogy a glikokalix enzimes emésztésével vagy egy sejtmembránba épülő pozitív töltésű hatóanyag, a lidokain használatával hogyan változik meg a felszíni töltés és gátmüködés, a humán hCMEC/D3 
sejtvonalat és a primer patkány modellt használtuk. További célunk volt, hogy elsőként jellemezük az őssejt-eredetű humán ko-kultúra modell vér-agy gát tulajdonságait dinamikus körülmények között funkcionális tesztekkel és génexpressziós analízissel.

Először a három modell gát tulajdonságait vizsgáltuk meg sejttenyésztő betétek és lab-on-a-chip eszköz segítségével. Kísérleteink során megmértük a sejteken keresztüli transzendoteliális elektromos ellenállást és különböző méretű fluoreszcens jelzőanyagok átjutását. A primer sejtes patkány ko-kultúra modell mutatta a legszorosabb paracelluláris gát-tulajdonságokat a statikus rendszerben, de a humán őssejt-eredetű ko-kultúra modellen mértük a legmagasabb ellenállást a biochip esetén. A legalacsonyabb ellenállás és a legmagasabb permeabilitás értékeket a humán hCMEC/D3 setjvonalon kaptuk mindkét kísérleti elrendezésben. Elsőként jellemeztük a humán őssejt-eredetű endotélsejt rétegeket egyedül, illetve pericitákkal együtt tenyésztve a chip eszköz felhasználásával. Ez a két modell megemelkedett ellenállást és csökkent permeabilitást mutatott a chipben a sejttenyésztő betétekhez képest. A sejtfelszíni glikokalix jelenlétét minden modellnél kimutattuk fluoreszcens lektin festéssel, azonban a jelölődést egyenetlennek találtuk, és a sejtmag körül magasabb intenzitást figyeltünk meg. A humán őssejt-eredetü modellen elsőként mutattuk ki a lab-on-a-chip eszköz segítségével, hogy pericitákkal történő együtt tenyésztés eredményeként a sejtfelszíni glikokalix sürüsége megnő az endotélsejteken a lektinfestés erőssége alapján.

A következő kísérletes célunk az agyi endotélsejtek sejtfelszíni töltésének közvetlen mérése, módosítása és ennek hatásának vizsgálata volt. Két megközelítést alkalmaztunk: (i) egyrészt neuraminidáz enzimet használtuk, amely a glikokalix alkotó elemei közül specifikusan a sziálsav oldalláncokat távolítja el, ezáltal pozitívabbá téve a felszíni töltést; (ii) másrészt a lipofil és pozitív töltésü lidokaint alkalmaztuk, amely képes beépülni a sejtmembránba. Arra a kérdésre kerestük a választ, hogy ez az ismert érzéstelenítő, illetve antiaritmiás szer megváltoztatja-e a vér-agy gát modellek sejtfelszíni töltését és befolyásolja-e a permeabilitásukat, különösen töltéssel rendelkező molekulák számára. Ezekben a kísérletekben a hCMEC/D3 sejtvonalat, mint a vér-agy gát egyszerüsített modelljét, és a primer patkány ko-kultúra modellt használtuk. Mindkét modellen lézer Doppler sebességméréssel állapítottuk meg az agyi endotélsejtek felszíni töltését, amely erősen negatívnak bizonyult. Kimutattuk, hogy a neuraminidáz kezelés az agyi belhámsejtek felszínéröl leemészti a sziálsav oldalláncokat, aminek következtében a felszíni töltés pozitívabbá válik. A sziálsav eltávolítása a glikokalix rétegről azonban nem változtatta meg a dextrán és az albumin átjutását az agyi endotélsejt rétegeken. Igazoltuk, hogy a lidokain kezelés is megváltoztatta agyi endotélsejtek sejtfelszíni töltését: a felszíni zéta potenciál értékek pozitívabbak lettek. A lidokain kezelés enyhén lecsökkentette az 
agyi endotél egysejtrétegek ellenállását, ami megemelkedett sejtek közötti ionátjutásra utal. Azonban a hidrofil jelzőanyagok, mint a lucifer sárga vagy a dextrán permeabilitása nem változott meg lidokain kezelés alatt. Ez a megfigyelés arra enged következtetni, hogy a lidokain feltehetőleg az ionok sejtek közötti átjutását változtatja meg, azonban a nagyobb vízoldékony molekulák permeabilitását nem befolyásolja. Ezzel ellentétben a lidokain kezelés a lipofil és kationos rodamin 123 agyi endotélrétegeken történő átjutását lecsökkentette, ami a pozitív töltésü lidokain és rodamin sejtmembrán szintü kölcsönhatására utalhat. Bebizonyítottuk továbbá, hogy a lidokain nem efflux pumpa gátló, így a rodamin permeabilitást nem ezen keresztül befolyásolja.

Mivel az őssejt-eredetü humán ko-kultúra vér-agy gát modellt eddig csak statikus körülmények között, sejttenyésztő betéteken vizsgálták, célul tűztük ki jellemzését labon-a-chip eszközben dinamikus körülmények között. Célunk a folyadékáramlás hatásának feltárása volt a gátmüködésre, a felszíni töltésre, a glikokalixra, illetve a génkifejeződésre. Kimutattuk, hogy folyadékáramlás hatására a gát tulajdonságok erősödtek és számos kulcsfontosságú, az endotélsejtekre, illetve a vér-agy gátra jellemző gén kifejeződése megemelkedett. Emellett a dinamikus körülmények nem csak az extracelluláris mátrix és a glikokalix kialakulásával kapcsolatos gének és útvonalak kifejeződését indukálták, de az agyi endotélsejtek felszíni töltése is negatívabbá vált, és a lektinkötő helyek száma is nőtt.

Összefoglalva megállapítottuk, hogy a kísérleteinkben használt vér-agy gát modellek humán és patkány agyi endotélsejtjeinek felszíni töltése nagymértékben negatív, ami összhangban áll egy korábbi, borjú agyi endotélsejteken tett megfigyeléssel. Elsőként írtuk le, hogy a glikokalix emésztése neuraminidáz enzimmel, illetve a lidokain kezelés módosították az agyi endotélsejtek felszíni töltését és megváltoztatták különböző vér-agy gát modellek barrier müködését. Eredményeink hozzájárulnak annak megértéséhez, milyen fontos szerepet játszik a felszíni negatív töltés és a glikokalix mint fizikai barrier a töltéssel rendelkező molekulák vér-agy gáton való átjuttatása szempontjából. A humán őssejt-eredetű vér-agy gát ko-kultúra modell új kísérletes eszköz lehet a sejtfelszíni glikokalix tanulmányozására a vér-agy gát élettani és kórélettani folyamatai során. Kísérleteink hozzájárulnak az agyi endotélsejtek felszíni töltésének és glikokalix rétegének, valamint töltéssel rendelkező molekulákkal történő kölcsönhatásának jobb megértéséhez. A chip eszközzel kapott eredmények megerősítik a folyadékáramlás használatának fontosságát vér-agy gát modelleknél. 


\section{Appendices}




\section{Publication I}




\title{
Lidocaine turns the surface charge of biological membranes more positive and changes the permeability of blood-brain barrier culture models
}

\author{
Ana R. Santa-Maria ${ }^{\mathrm{a}, \mathrm{b}}$, Fruzsina R. Walter ${ }^{\mathrm{a}}$, Sándor Valkai ${ }^{\mathrm{a}}$, Ana Rita Brás ${ }^{\mathrm{a}}$, Mária Mészáros ${ }^{\mathrm{a}, \mathrm{c}}$, \\ András Kincses $^{\mathrm{a}, \mathrm{d}}$, Adrián Klepe ${ }^{\mathrm{a}}$, Diana Gaspar ${ }^{\mathrm{e}}$, Miguel A.R.B. Castanho ${ }^{\mathrm{e}}$, László Zimányi ${ }^{\mathrm{a}}$, \\ András Dér ${ }^{\mathrm{a}, *}$, Mária A. Deli ${ }^{\mathrm{a}, *}$ \\ a Institute of Biophysics, Biological Research Centre, Hungarian Academy of Sciences, Temesvári krt. 62, H-6726 Szeged, Hungary \\ ${ }^{\mathrm{b}}$ Doctoral School of Biology, University of Szeged, Hungary \\ ${ }^{\mathrm{c}}$ Doctoral School of Theoretical Medicine, University of Szeged, Hungary \\ ${ }^{\mathrm{d}}$ Doctoral School of Multidisciplinary Medical Sciences, University of Szeged, Hungary \\ e Instituto de Medicina Molecular, Faculdade de Medicina da Universidade de Lisboa, Lisboa, Portugal
}

\section{A R T I C L E I N F O}

\section{Keywords:}

Bacteriorhodopsin

Blood-brain barrier

Brain endothelial cells

Lidocaine

Permeability

Surface charge

\begin{abstract}
A B S T R A C T
The surface charge of brain endothelial cells forming the blood-brain barrier (BBB) is highly negative due to phospholipids in the plasma membrane and the glycocalyx. This negative charge is an important element of the defense systems of the BBB. Lidocaine, a cationic and lipophilic molecule which has anaesthetic and antiarrhytmic properties, exerts its actions by interacting with lipid membranes. Lidocaine when administered intravenously acts on vascular endothelial cells, but its direct effect on brain endothelial cells has not yet been studied. Our aim was to measure the effect of lidocaine on the charge of biological membranes and the barrier function of brain endothelial cells. We used the simplified membrane model, the bacteriorhodopsin (bR) containing purple membrane of Halobacterium salinarum and culture models of the $\mathrm{BBB}$. We found that lidocaine turns the negative surface charge of purple membrane more positive and restores the function of the proton pump bR. Lidocaine also changed the zeta potential of brain endothelial cells in the same way. Short-term lidocaine treatment at a $10 \mu \mathrm{M}$ therapeutically relevant concentration did not cause major BBB barrier dysfunction, substantial change in cell morphology or P-glycoprotein efflux pump inhibition. Lidocaine treatment decreased the flux of a cationic lipophilic molecule across the cell layer, but had no effect on the penetration of hydrophilic neutral or negatively charged markers. Our observations help to understand the biophysical background of the effect of lidocaine on biological membranes and draws the attention to the interaction of cationic drug molecules at the level of the BBB.
\end{abstract}

\section{Introduction}

Every biological membrane shares the same phospholipid bilayer structure, where the hydrophobic fatty acid tail of the phospholipids and the hydrophilic, ionized polar head groups line both surfaces and create the basis of the surface charge of the cell membrane. This surface charge can contribute to the passive or active permeability of ions and metabolites [1,2]. Amphipathic drugs, like many anaesthetics interact with the phospholipid bilayer membranes according to the bilayer couple hypothesis which states that amphipathic drugs affect cells by the asymmetric insertion into one side of the lipid bilayer which increases membrane fluidity [3,4]. Lidocaine is a commercially available tertiary amine used as local anaesthetic. In addition, this lipophilic drug has anti-hyperalgesic, analgesic, anti-inflammatory properties and is also used to treat cardiac arrhythmia [5-7]. Lidocaine after being intravenously injected dissociates to a positively charged quaternary amine and to uncharged base forming an in vivo equilibrium between the uncharged and charged molecules, which depends on the local $\mathrm{pH}$

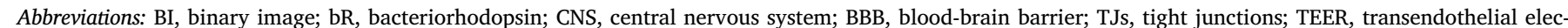

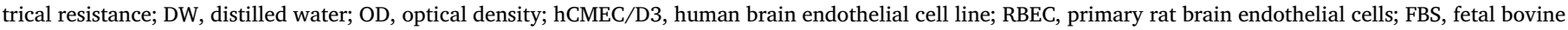

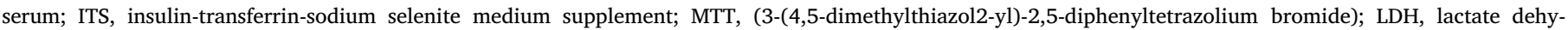

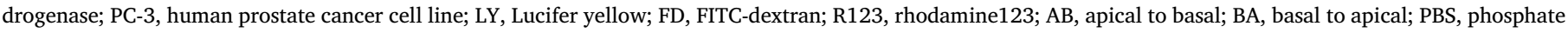
buffered saline; BSA, bovine serum albumin

* Corresponding authors.

E-mail addresses: der.andras@brc.mta.hu (A. Dér), deli.maria@brc.mta.hu (M.A. Deli). 
[8]. Although the mode of action of local anaesthetics is not fully understood, it is clear that they interact with lipid membranes [9], change the fluidity, micro-viscosity and permeability $[8,10]$. Hypotheses for the mode of action include that lidocaine might interact with membrane proteins binding to the intracellular site of the voltage-gated sodium channels blocking its action or just inserts to the membrane [9] and interferes with the channel conductivity by changing its shape $[8,11,12]$. The most accepted theory is that lidocaine inserts to specific binding sites in the membrane, and by its charge blocks the $\mathrm{Na}^{+}$current across the cell membrane [11].

Bacteriorhodopsin (bR) is a good simplified model to investigate charge-related changes of biological membranes. bR is a seven transmembrane-helix light driven proton pump with a covalently bound retinal chromophore, found in the cell membrane of Halobacterium salinarum, forming purple patches, the so called "purple membrane" [13]. The purple color of the chromophore of bR can be converted to blue, reflecting the inhibition of the proton pump, by two methods: either by removing divalent cations bound to the purple membrane (the "deionized blue" from) [14] or lowering the $\mathrm{pH}$ by sulfuric acid solution (the "acid blue" form below pH 3.1-3.2) [15]. The functional bR can be restored either by the addition of cations or raising the $\mathrm{pH}$. It has been shown that cationic lidocaine is able to restore the purple color and the function of the proton pump in deionized bR $[16,17]$, but its effect on acid blue bR has not yet been investigated.

Brain endothelial cells form the morphological basis of the bloodbrain barrier (BBB) together with pericytes and glial endfeet, and are key elements in maintaining and regulating the homeostasis of the central nervous system $[18,19]$. The most important parts of the physical barrier of the BBB are the interendothelial tight junctions (TJs) and the negative surface charge of brain endothelial cells. This negative charge is derived from the endothelial glycocalyx composed of sialoglycoconjugates and heparan sulfate proteoglycans [20,21] and the special lipid composition of the plasma membrane of brain endothelial cells [22]. In contrast to other cell types, the negatively charged phosphatidylserine and phosphatidilcholine were the most abundant in endothelial cells from brain [22]. The negative surface charge contributes to the regulation of the permeability for positively charged molecules at the BBB $[21,22]$.

Lidocaine is administered intravenously to treat cardiac arrhythmia [6], therefore it interacts directly with vascular endothelial cells, including brain capillary endothelial cells. According to previous studies lidocaine affects the electrostatic potential of lipid bilayers: the charged molecular form acts at the lipid headgroups, while the uncharged molecule increases the electrostatic potential in the middle of the membrane $[23,24]$. In the present study our aim was to understand how lidocaine interacts with cell membranes using a simple membrane system containing bR and cell culture models of the BBB. We are the first to study the direct action of lidocaine on the surface charge of brain endothelial cells and their function including electrical resistance and permeability. The endothelial surface charge and its relationship to barrier function is an underresearched area of the BBB field. We hypothesized that lidocaine, a cationic drug molecule, can directly influence the permeability of charged molecules across the BBB.

\section{Methods}

\subsection{Animals}

Organ harvest from animals was performed according to the regulations of the 1998. XXVIII. Hungarian law and the EU Directive 2010/ $63 / \mathrm{EU}$ about animal protection and welfare. The local animal health authority, the Governmental Office for Csongrád County, Directorate of Food Chain Safety and Animal Health approved our studies (Permit numbers: XVI/834/2012). For primary cell isolations brain tissues were obtained from 4-week old and 1-day-old Wistar rats (Harlan Laboratories, United Kingdom) of both sexes. Animals were kept under a $12 \mathrm{~h}$ light/dark cycle and fed on standard rodent chow and water ad libitum in the conventional animal house of the Biological Research Centre. Following the 3R-rule all efforts were made to minimize animal suffering and pain.

\subsection{Materials}

All reagents were purchased from Sigma-Aldrich Ltd. Hungary (part of Merck Life Science), unless otherwise indicated.

\subsection{Treatments}

All treatments performed on bR or in vitro cell cultures were done using a stock solution of lidocaine ( $20 \mathrm{mM}$, Sigma L7757). Lidocaine was dissolved in water at $30^{\circ} \mathrm{C}$. Stocks were always prepared freshly before each experiment.

\subsection{Bacteriorhodopsin assays}

\subsubsection{Preparation of purple membrane}

Purple membranes containing bR were isolated as described previously [13] from Halobacterium salinarum strain $\mathrm{R}_{1}$, which homologously expresses wild type bR and does not tend to form vacuoles, thereby facilitating the isolation procedure. Cultures of $H$. salinarum archaebacteria were grown for about $70-90 \mathrm{~h}$ in a shaking incubator, then the culture was centrifuged, pelleted and re-suspended in $200 \mathrm{ml}$ of $25 \% \mathrm{NaCl}$ solution with $5 \mathrm{mg}$ of DNase. After dialysis against distilled water (DW) the red clear lysate was centrifuged (30 min at $50000 \mathrm{~g}$ ) and a purple pellet was obtained. To separate the purple membranes from other fragments the pellet was washed once with $4.3 \mathrm{M} \mathrm{NaCl}$, once with $0.1 \mathrm{M} \mathrm{NaCl}$ and finally with DW. In the end the purple membrane was centrifuged in a concentration gradient of sucrose from 0.5 to $1.5 \mathrm{M}$ for $10 \mathrm{~h}$ at $200000 \mathrm{~g}$ in order to remove the red material. From 101 of bacteria suspension $300-500 \mathrm{mg}$ of purple membrane is gained.

\subsubsection{Preparation of polyacrylamide gels}

The effects of lidocaine were studied on purple membranes which were immobilized in $0.1 \%$ polyacrylamide gel as described previously [25]. Briefly, the gels were prepared using the combination of two solutions. First, tetramethyl-ethylene-diamine (TEMED, Serva, Hungary) was added to the purple membrane suspension with a final dilution of $0.35 \%(v / v)$ to prepare the first solution with an optical density (OD) of 4. Then $30 \%$ acrylamide/bis mixture (BioRad, Hungary) was prepared containing ammonium persulfate (Serva, Hungary) at a final concentration of $0.1 \%(v / v)$. At the end the two solutions were combined and poured into a mould where it polymerized and remained in DW for $24 \mathrm{~h}$.

\subsubsection{Treatment of polyacrylamide gels containing purple membrane}

Gels containing purple membranes were incubated with different concentrations of lidocaine. For this treatment lidocaine solutions of 10 and $1 \mathrm{mM}$ were prepared in $0.5 \mathrm{mM} \mathrm{H}_{2} \mathrm{SO}_{4}$ (pH 3.0-3.2). The gel slabs ( $4 \times 4 \times 20 \mathrm{~mm}$ in dimension) were soaked in glass flasks containing $15 \mathrm{ml}$ of each treatment solution at $4{ }^{\circ} \mathrm{C}$ in the dark for a minimum of $24 \mathrm{~h}$. After the incubation photocycle measurement was performed [26], where a blank gel that did not contain bR was used as a reference. The gel samples were placed in rectangular plastic cuvettes with both the measuring light and the perpendicular exciting laser light crossing through $4 \mathrm{~mm}$ pathlengths. The temperature of the samples was kept at $20^{\circ} \mathrm{C}$ during the measurements. Absorption spectra of the samples were taken with a ScanSci miniature spectrophotometer [UNICAM UV/Vis Spectrometer UV4] prior to the photocycle measurement. Time resolved difference spectra after the exciting laser pulse (Continuum Surelight Nd-YAG laser + OPO, appr. $10 \mathrm{~ns}$ pulse width) were taken using home built timing and triggering units and an Andor iStar gated CCD detector attached to a Jobin Yvon HR300 spectrograph. The white 
measuring light from a $35 \mathrm{~W}$ Hamamatsu high pressure Xe light source was chopped with a Uniblitz shutter to provide illumination for several tens of milliseconds only during a measuring cycle of $3 \mathrm{~s}$. For the sample in $10 \mathrm{mM}$ lidocaine solution, $\mathrm{pH} 3.0,560 \mathrm{~nm}$, for that without lidocaine, at $\mathrm{pH} 3.0,630 \mathrm{~nm}$ laser pulses were applied in the several $100 \mu \mathrm{J}$ range. Difference spectra were measured on a logarithmically equidistant manner from $250 \mathrm{~ns}$ to $630 \mathrm{~ms}$ with 5 spectra per decade.

\subsection{Cell cultures}

\subsubsection{Blood-brain barrier models}

2.5.1.1. hCMEC/D3 human brain endothelial cell line. The human hCMEC/D3 brain endothelial cell line [27] was purchased from Merck Millipore. The cultures of hCMEC/D3 (spassage number 35) were grown at $37^{\circ} \mathrm{C}, 5 \% \mathrm{CO}_{2}$ in $\mathrm{MCDB} 131$ medium (Pan Biotech) supplemented with $5 \%$ fetal bovine serum (FBS), GlutaMAX $(100 \times$, Life Technologies, USA), lipid supplement $(100 \times$, Life Technologies, USA), $10 \mu \mathrm{g} / \mathrm{ml}$ ascorbic acid, $550 \mathrm{nM}$ hydrocortisone, $100 \mu \mathrm{g} / \mathrm{ml}$ heparin, $1 \mathrm{ng} / \mathrm{ml}$ basic fibroblast growth factor (bFGF, Roche, USA), $5 \mu \mathrm{g} / \mathrm{ml}$ insulin-transferrin-selenium (ITS) supplement $(100 \times$, PanBiotech, Germany), $10 \mathrm{mM}$ HEPES and gentamycin $(50 \mu \mathrm{g} / \mathrm{ml})$. Medium change was performed every two or three days. When cells reached a confluence of $90 \%$ they were passaged for transendothelial electrical resistance (TEER) measurements and permeability assays to rat tail collagen-coated Transwell clear inserts (\#3460, $0.4 \mu \mathrm{M}$ pore size, polyester membrane, Corning Costar), for the zeta measurements to $60 \mathrm{~mm}$ Petri dishes (Corning Costar, USA) and for the viability assays to 96-well plates (E-plate, ACEA Biosciences, USA or Corning Costar, USA) Before each experiment the medium was supplemented with $10 \mathrm{mM} \mathrm{LiCl}$ for $24 \mathrm{~h}$ to improve BBB properties [28].

2.5.1.2. Primary cell cultures. The isolation of primary rat brain endothelial cells (RBEC), glial cells and pericytes and the construction of the in vitro BBB model were done according to the method described in our previous studies [29,30]. After isolation, primary brain endothelial cells were seeded on petri dishes (Corning Costar, USA) coated with $100 \mu \mathrm{g} / \mathrm{ml}$ collagen type IV and $100 \mu \mathrm{g} / \mathrm{ml}$ fibronectin in sterile distilled water. The cells were cultured in DMEM/F-12 (Gibco, Life Technologies, USA), 15\% plasma derived bovine serum (PDS, First Link, UK), $100 \mu \mathrm{g} / \mathrm{ml}$ heparin, $5 \mu \mathrm{g} / \mathrm{ml}$ insulin, $5 \mu \mathrm{g} / \mathrm{ml}$ transferrin, $5 \mathrm{ng} / \mathrm{ml}$ sodium selenite (ITS), $1 \mathrm{ng} / \mathrm{ml}$ bFGF (Roche, USA), $10 \mathrm{mM}$ HEPES and $50 \mu \mathrm{g} / \mathrm{ml}$ gentamicin. For the first 3 days of culture $3 \mu \mathrm{g} / \mathrm{ml}$ puromycin was added to the base medium to eliminate P-glycoprotein negative, contaminating cell types [31].

The primary rat brain pericytes were isolated using the same method as described previously, except that pericytes were seeded to uncoated petri dishes (Corning, Costar, USA). Primary cultures of glial cells were prepared from one-day-old Wistar rats and passaged to 12well plates (Corning, Costar, USA) coated with $100 \mu \mathrm{g} / \mathrm{ml}$ collagen type IV in sterile distilled water. Cultures of rat glial cells were maintained for 2 weeks before using them for the triple co-culture model. The pericytes and glial cells were kept in low glucose DMEM (Gibco, Life Technologies, USA) supplemented with 10\% FBS (Gibco, Life Technologies, USA) and $50 \mu \mathrm{g} / \mathrm{ml}$ gentamicin.

The triple co-culture of the primary cells was assembled as described before [29]. Briefly, pericytes at passage number two were seeded at a density of $1.5 \times 10^{4} / \mathrm{cm}^{2}$ to the bottom of the membranes of Transwell clear cell culture inserts, while RBECs were passaged to the top of the membranes at a number of $7.5 \times 10^{4} / \mathrm{cm}^{2}$. The inserts were placed into the 12-well plates containing the glial cultures. The triple BBB co-culture model received endothelial culture medium supplemented with $550 \mathrm{nM}$ hydrocortisone and it was cultured together for 4 to 5 days [29]. After the in vitro BBB model was established TEER measurements, permeability assays and immunohistochemistry were performed. One day before the permeability assay cells were treated with chlorophenylthio-adenosine-3,5-cyclic monophosphate $(250 \mu \mathrm{M}$,
CPT-cAMP) and phosphodiesterase inhibitor RO $201724(17.5 \mu \mathrm{M}$, Roche) to tighten junctions and elevate resistance [31,32].

\subsection{2. $P C-3$ human prostate cancer cell line}

The PC-3 cell line was purchased from the American Type Culture Collection (ATCC, USA). The cells were cultured in RPMI medium (Gibco), supplemented with 10\% FBS and 1\% penicillin-streptomycin solution. The cultures were kept in a $10 \mathrm{~cm}$ petri dish until reaching $80-90 \%$ of confluency, then they were trypsinized and used for the zeta measurements.

\subsection{Cell viability assays}

\subsubsection{Impedance measurement}

Kinetics of the viability of brain endothelial cells after lidocaine treatment was monitored by real time impedance measurement (RTCASP, ACEA Biosciences, San Diego, CA, USA). Impedance measurement correlates linearly with cell number, adherence, growth and viability [30]. Brain endothelial cells (hCMEC/D3 and RBECs) were seeded at a cell number of $5 \times 10^{3} /$ well onto a 96-well E-plate (ACEA Biosciences) with golden electrodes at the bottom of the wells, and were kept in the $\mathrm{CO}_{2}$ incubator at $37^{\circ} \mathrm{C}$ for $4-5$ days, and treated at the beginning of the plateau phase of cell growth with $0,1,3,10,30,100,300$ and $1000 \mu \mathrm{M}$ concentrations of lidocaine. Triton X-100 detergent was used to determine $100 \%$ toxicity. Effects of the treatment were followed for $24 \mathrm{~h}$.

\subsubsection{MTT and lactate dehydrogenase release assays}

For these assays brain endothelial cells (hCMEC/D3 and RBECs) were seeded onto 96-well plates (Corning Costar, USA) at a cell number of $5 \times 10^{3} /$ well. Confluent cultures were treated with $0-1000 \mu \mathrm{M}$ of lidocaine or for $30 \mathrm{~min}$, Triton $\mathrm{X}-100$ was used as a $100 \%$ cytotoxic control.

Viable cells convert the yellow MTT dye (3-(4,5-dimethylthiazol2yl)-2,5-diphenyltetrazolium bromide) to purple formazan crystals reflecting metabolic activity. After lidocaine treatment MTT solution $(0.5 \mathrm{mg} / \mathrm{ml})$ was added and cells were incubated for $3 \mathrm{~h}$ at $37^{\circ} \mathrm{C}$. Formazan crystals produced by living cells were dissolved with dimethyl sulfoxide, and absorbance was measured at $570 \mathrm{~nm}$ by a multiwell microplate reader (Fluostar Optima, BMG Labtechnologies, Germany). Cytotoxicity was calculated as a percentage of the control where the maximum dye conversion was detected.

In order, to investigate membrane damage the presence of intracellular lactate dehydrogenase (LDH) enzyme was determined from the supernatant using a commercially available kit [33]. After treatment, culture supernatants $(50 \mu \mathrm{l})$ were collected into another 96-well plate and were incubated with equal amounts of reaction mixture for $15 \mathrm{~min}$ on a horizontal shaker according to the manufacturer's protocol (Cytotoxicity detection kit LDH, Roche). Enzyme reaction was stopped with $0.1 \mathrm{M}$ of $\mathrm{HCl}$ and absorbance was measured at $450 \mathrm{~nm}$ wavelength using a multiwell microplate reader (Fluostar Optima, BMG Labtechnologies, Germany). Cytotoxicity was calculated as a percentage of the total LDH release from cells treated with $1 \%$ Triton X-100 detergent.

\subsection{Zeta potential measurements}

The zeta potential $(\zeta)$ was measured by dynamic light scattering using a Zetasizer Nano ZS instrument (Malvern, UK) equipped with a He-Ne laser $(\lambda=632.8 \mathrm{~nm})$. The zeta-potential of the samples was measured at $25^{\circ} \mathrm{C}$, from a minimum of 6 measurements (maximum 100 runs each), with an applied 20 or $40 \mathrm{~V}$ voltage, using disposable zeta potential cells with gold-coated platinum electrodes (DTS1070, Malvern, UK) [22]. Before measurements the zeta cuvettes were activated once with $100 \%$ ethanol and rinsed twice with distilled water. After activation, the zeta cuvettes were calibrated with the zeta standard solution (Malvern, UK) as described in the manufacturer's 
protocol. For purple membrane samples, the zeta potential measurements were performed at $\mathrm{OD}=0.1$ diluted in $0.5 \mathrm{mM}$ sulfuric acid. Treatment of purple membrane samples was performed with $10 \mathrm{mM}$ lidocaine for $30 \mathrm{~min}$. Cuvettes were always rinsed twice with distilled water between measurements. The hCMEC/D3 and RBEC brain endothelial cells, and PC-3 human prostate cancer cells were used for zeta measurements after cultures reached $90 \%$ confluency. Trypsinization of the cells was performed very quickly to minimize plasma membrane changes. After trypsinization, $10^{5}$ cells were re-suspended in $1 \mathrm{ml}$ of PBS with $\mathrm{Ca}^{2+}$ and $\mathrm{Mg}^{2+}$. Cells were treated with different concentrations of lidocaine $(10,100$ and $1000 \mu \mathrm{M})$ for $30 \mathrm{~min}$ before the measurement at $37^{\circ} \mathrm{C}$. The Zetasizer Software v.7.12. calculated the zeta potential values using the Smoluchowski equation [34]:

$\zeta=\frac{4 \pi \mu \eta}{\varepsilon}$

where $\mu$ represents the electrophoretic mobility, $\eta$ the viscosity of the solvent and $\varepsilon$ the dielectric constant.

\subsection{Evaluation of barrier integrity}

\subsubsection{Transendothelial electrical resistance}

The BBB models (hCMEC/D3 and the primary cell based co-culture) prepared on inserts received fresh culture medium every second day. To follow the development of the barrier properties of the brain endothelial monolayers TEER was measured before every medium change with an EVOM voltohmmeter (World Precision Instruments Inc., USA) combined with STX-2 electrodes. TEER was expressed relative to the surface of the inserts $\left(\Omega \times \mathrm{cm}^{2}\right)$. The TEER of cell-free inserts $\left(100 \Omega \times \mathrm{cm}^{2}\right)$ was subtracted from the measured values. TEER before and after lidocaine treatment was measured in Ringer-Hepes buffer supplemented with $1 \%$ BSA and ITS. This buffer had the same composition as used for the permeability measurements. To decrease fluctuations in the TEER due to temperature change measurements were performed by placing the culture plates to a heating pad set to $37^{\circ} \mathrm{C}$.

\subsubsection{Permeability measurement with marker molecules of different surface} charge

Permeability tests on the BBB models on inserts were performed when TEER values reached previously published values (86 \pm 9 , $\mathrm{n}=24$ for D3, $255 \pm 15$ for RBEC $\mathrm{n}=24$ co-culture; [35]), showing the barrier properties for both models. For the permeability experiments inserts were transferred to 12 -well plates containing $1.5 \mathrm{ml}$ Ringer-HEPES buffer (118 mM NaCl, $4.8 \mathrm{mM} \mathrm{KCl,} 2.5 \mathrm{mM} \mathrm{CaCl}$, $1.2 \mathrm{mM} \mathrm{MgSO}_{4}, 5.5 \mathrm{mM}$ D-glucose, $10 \mathrm{mM}$ HEPES, pH 7.4) supplemented with $1 \%$ BSA and ITS in the lower (basal/abluminal) compartment. In the upper (apical/luminal) compartment culture medium was replaced with $0.5 \mathrm{ml}$ buffer containing $10 \mu \mathrm{M}$ lidocaine and molecular markers with different surface charges: FITC-dextran $(10 \mu \mathrm{g} / \mathrm{ml}$, FD, Mw: $10 \mathrm{kDa}$ ) with neutral charge, positively charged rhodamine123 $(10 \mu \mathrm{M}$, R123, Mw: $380 \mathrm{Da})$ and negatively charged Lucifer yellow ( $5 \mu \mathrm{M}$, LY, Mw: $457 \mathrm{Da}$ ). Cells serving as control were only incubated with the fluorescent markers without any lidocaine treatment. The plates were kept in a $\mathrm{CO}_{2}$ incubator at $37^{\circ} \mathrm{C}$ on a horizontal shaker $(150 \mathrm{rpm})$ for $30 \mathrm{~min}$. After incubation the samples were collected from the compartments and the concentrations of the marker molecules were determined by a spectrofluorometer (Horiba Jobin Yvon Fluorolog 3, Kyoto, Japan). Excitation/emission values for the different markers were: $440 \mathrm{~nm} / 516 \mathrm{~nm}$ for FD; $498 \mathrm{~nm} / 525 \mathrm{~nm}$ for R123; $420 \mathrm{~nm}$ / $535 \mathrm{~nm}$ for LY.

Transendothelial permeability coefficient $\left(\mathrm{P}_{\mathrm{e}}\right)$ was calculated as previously described $[29,30]$. Briefly, clearance was calculated from the transport of the fluorescent marker molecule from the donor to the acceptor compartment expressed as $\mu \mathrm{l}$ of donor compartment volume from which the tracer was completely cleared. The average cleared volume was plotted $v$ s. time, and permeability surface area product value for endothelial monolayer $\left(\mathrm{PS}_{\mathrm{e}}\right)$ was calculated by the following formula:

$\frac{1}{P S_{\text {endothelial }}}=\frac{1}{P S_{\text {total }}}-\frac{1}{P S_{\text {insert }}}$

PSe was normalized for the surface area of the Transwell insert $\left(1.12 \mathrm{~cm}^{2}\right)$ and was expressed as $10^{-6} \mathrm{~cm} / \mathrm{s}$. In measurements from the apical to basal $(\mathrm{AB})$ direction the upper compartment served as the donor and the lower compartment as the acceptor. In the case of the basal to apical (BA) direction the donor compartment was the lower, while the acceptor compartment was the upper one.

\subsubsection{Immunohistochemistry}

After the permeability assays brain endothelial cells were stained for junctional associated proteins $\beta$-catenin and $\mathrm{ZO}-1$ and for tight junction protein claudin- 5 to assess the morphological changes after lidocaine treatment. Cells were fixed with cold acetone-methanol solution (1:1) for $2 \mathrm{~min}$, washed with phosphate buffered saline (PBS) and non-specific binding sites were blocked with $3 \%$ bovine serum albumin (BSA) in PBS for $1 \mathrm{~h}$ at room temperature. Incubation with primary antibodies (dilution 1:200) polyclonal rabbit anti- $\beta$-catenin (Sigma C2206), polyclonal rabbit anti-ZO-1 (Invitrogen, 61-7300) and polyclonal rabbit anti-claudin-5 (Sigma, SAB4502981) lasted overnight at $4{ }^{\circ} \mathrm{C}$. The next day cells were incubated with anti-rabbit secondary antibody labeled with Cy3 (Sigma C2306; dilution 1:400), and bis-benzimide H33342 (Merck, Germany) to stain nuclei, for $1 \mathrm{~h}$ at room temperature. Between incubations cells were washed three times with PBS. Stainings were visualized by a Leica TCS SP5 confocal laser scanning microscope (Leica Microsystems, Germany). Pictures for the junctional-cytoplasm intensity ratio evaluations were taken with the exact same settings among cell types and stainings.

\subsection{Image analysis}

The fluorescently labeled images were analysed using Matlab software (R2019a, MathWorks, Inc.). In brain endothelial cells the fluorescent intensity of the immunostaining for junctional proteins in the cell membrane is higher than in the cytoplasm. First we determined the cytoplasmic intensity, from which binary images (BIs) were created. The complementary BIs were considered as the junctional staining in the plasma membrane. The pixels in the two BIs were used as masks, and the intensities of the original pixels were summed in both the junctional BIs and the cytoplasmic BIs separately. The ratio of the cell membrane and cytoplasm intensities for each image was determined and used for the statistical analysis. The number of images were 11-15 in each group.

\subsection{Measurement of efflux pump activity}

The activity of the P-glycoprotein efflux pump was measured by R123, a ligand of this transporter, similarly to the permeability assay, but both in the $\mathrm{AB}$ and $\mathrm{BA}$ directions. For measurements in the BA direction the donor compartment was the lower, while the acceptor compartment was the upper one. As a reference Pgp pump inhibitor, cyclosporin A $(10 \mu \mathrm{M})$ was used (30 min pre-treatment of cells). During the assay cells were incubated for $30 \mathrm{~min}$ with $10 \mu \mathrm{M} \mathrm{R} 123$ with or without $10 \mu \mathrm{M}$ lidocaine in Ringer-HEPES buffer. After the incubation samples were collected from the upper and lower compartments and the concentration of R123 in the samples was determined by a spectrofluorometer (Horiba Jobin Yvon Fluorolog 3; excitation/emission: $498 / 525 \mathrm{~nm})$.

\subsection{Statistics}

Data are presented as means \pm SD. Statistical significance between treatment groups was determined using $t$-test, one-way or two-way 
A

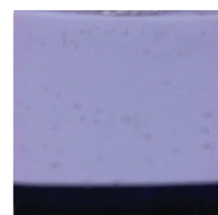

$0 \mathrm{mM}$

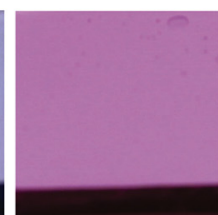

$1 \mathrm{mM}$

B

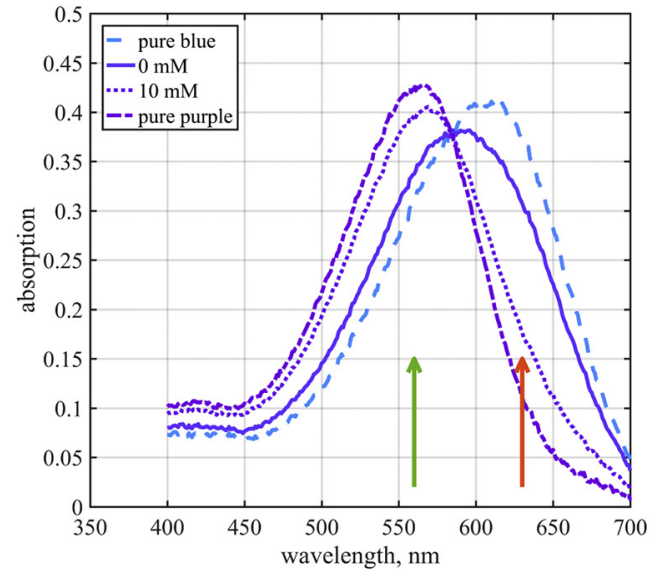

C

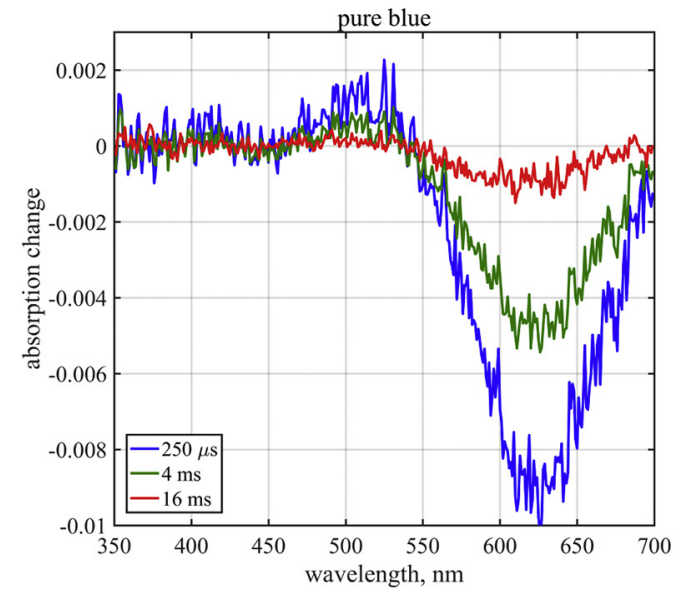

D

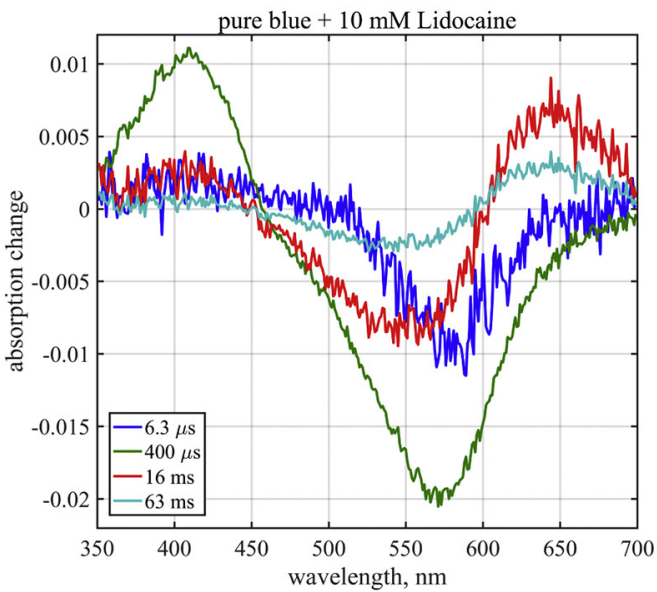

Fig. 1. Effects of lidocaine on the purple membrane. A: Photos of the gels containing purple membrane in $0.5 \mathrm{mM}$ sulfuric acid $(\mathrm{pH}=3.2)$ without and after $1 \mathrm{mM}$ and $10 \mathrm{mM}$ lidocaine treatment. B: Absorption spectra of purple membrane containing gels incubated with and without lidocaine $(10 \mathrm{mM}$; $\mathrm{pH}=3.0$ ) as well as the calculated spectra for the pure purple and blue forms (see text). The arrows indicate the wavelength of the exciting laser pulses for the two samples. C, D: Time resolved difference spectra of purple membranes in polyacrylamide gel at $\mathrm{pH} 3.0$, without (C) and with (D) $10 \mathrm{mM}$ lidocaine.

ANOVA followed by Dunnett or Bonferroni multiple comparison posttests (GraphPad Prism 5.0; GraphPad Software, USA). All experiments were repeated at least twice, and the number of parallel samples was minimum three. Changes were considered statistically significant at $\mathrm{p}<0.05$.

\section{Results}

\subsection{Effect of lidocaine on the purple membranes}

The chromophore of the bR is sensitive to the absence of divalent cations bound to the purple membrane at neutral $\mathrm{pH}$ : upon removal of divalent cations by deionizing the membrane suspension, the color of bR changes from purple to blue, which is accompanied by inactivation of the proton pump [14]. Purple membrane also turns blue, and the proton pump is inhibited in sulfuric acid solution with $\mathrm{pH}$ below 3.1-3.2 [15]. This condition is shown on Fig. 1A when no lidocaine treatment is present and the gels containing purple membrane turn blue due to the acidic $\mathrm{pH}$. Lidocaine treatment at 1 and $10 \mathrm{mM}$ concentrations reversed this color change (Fig. 1A), an effect that was concentration dependent.

Fig. 1B shows the absolute spectra of the samples with and without $10 \mathrm{mM}$ lidocaine treatment at $\mathrm{pH}$ 3.0. As observed also visually, the sample without lidocaine was blue (pure blue) as expected at this $\mathrm{pH}$ due to the protonation of the proton acceptor Asp85 already in the resting state of the pigment. The sample treated with $10 \mathrm{mM}$ lidocaine at pH 3.0 turned purple. The absorption spectrum of the latter has a maximum close to the position expected at neutral $\mathrm{pH}$, whereas that of the blue membrane is substantially red shifted. As both spectra appeared wider than the spectrum of $\mathrm{bR}$ at higher $\mathrm{pH}$, we estimate that both are mixtures of the pure purple and pure blue forms. An estimate of $25 / 75 \%$ and $75 / 25 \%$ contribution of the purple and blue forms to the zero and the $10 \mathrm{mM}$ lidocaine samples, respectively, yields narrower calculated spectra of the two pure forms (Fig. 1B). Representative time resolved difference spectra measured on the purple membrane containing gel samples at $\mathrm{pH} 3.0$, with and without $10 \mathrm{mM}$ lidocaine treatment, are shown in Fig. 1C and D. The purple samples in $10 \mathrm{mM}$ lidocaine display a regular photocycle typical at higher $\mathrm{pH}$ with consecutive $\mathrm{L}, \mathrm{M}$ and $\mathrm{O}$ intermediates, with characteristic absorption peaks seen at $6.3 \mu \mathrm{s}$ after excitation at $410 \mathrm{~nm}(\mathrm{~L}) ; 400 \mu \mathrm{s}, 410 \mathrm{~nm}(\mathrm{M})$ and $16 \mathrm{~ms}, 640 \mathrm{~nm}(\mathrm{O})$, followed by the recovery of the initial bR state in about $100 \mathrm{~ms}$. The amount of accumulated $\mathrm{O}$ in the 10-100 ms range is relatively high as expected for the "normal" photocycle below the $\mathrm{p} K_{\mathrm{a}}=5.8$ of the proton release cluster [37], where proton release is delayed to the very end of the cycle, coinciding with the decay of the $\mathrm{O}$ intermediate. On the other hand, the photocycle without lidocaine is characteristic of the truncated cycle of the blue membrane. Here $M$ does not accumulate since the proton acceptor Asp85 is already initially protonated so that the Shiff base cannot deprotonate. After the accumulation of a small amount of L-like intermediate the photocycle terminates faster than in the case of the purple membrane.

\subsection{Modulation of surface charge of purple membranes}

Due to the absence of a direct measurement for the surface charge, to evaluate the electrostatic properties of membrane surface, zeta 


\section{Bacteriorhodopsin}

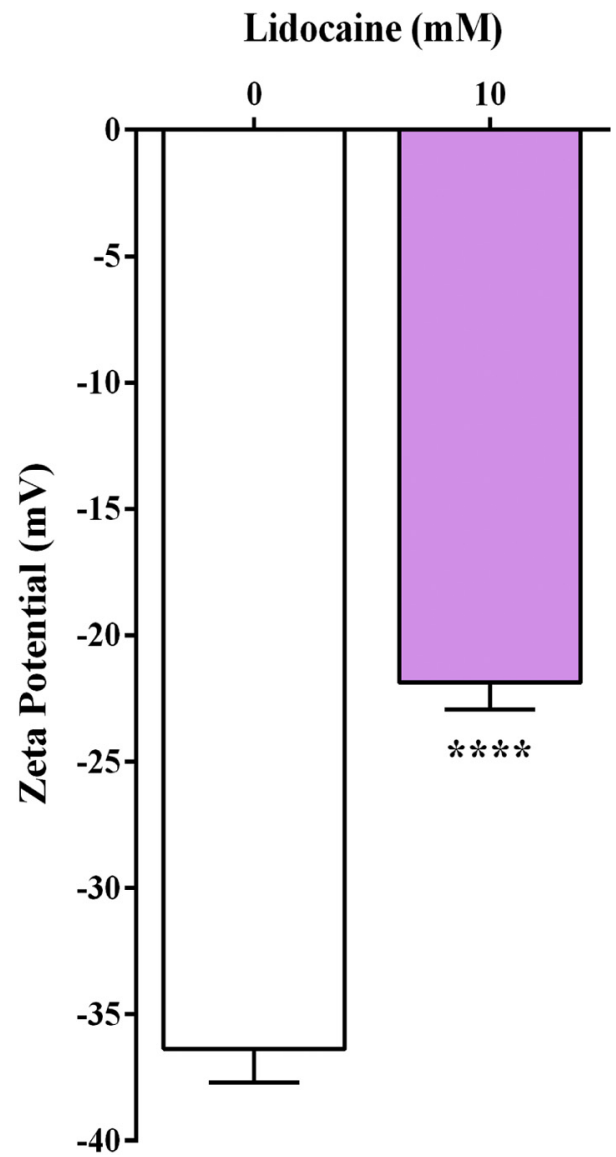

Fig. 2. Modulation of surface charge of purple membrane. Zeta potential of purple membrane in $0.5 \mathrm{mM} \mathrm{H}_{2} \mathrm{SO}_{4}(\mathrm{pH}=3.2)$ without and with $10 \mathrm{mM}$ lidocaine treatment $(30 \mathrm{~min})$. Values of each group are presented as mean $\pm \mathrm{SD}$, $\mathrm{n}=10$. Data were analysed by unpaired $t$-test. ${ }^{* * * *} \mathrm{p}<0.0001$, compared to the untreated control.

potential can be determined [22]. We measured the zeta potential of purple membranes in $0.5 \mathrm{mM}$ sulfuric acid and found it highly negative $(-36.4 \pm 0.4 \mathrm{mV}$, Fig. 2). Lidocaine treatment for 30 min changed this value to more positive $(-21.9 \pm 0.3 \mathrm{mV})$, indicating a direct action of the cationic drug on the charge of membranes containing bR. This shift in the charge can explain the changes we observed in the purple membrane color (Fig. 1A) and the shift in the bR spectrum (Fig. 1B).

\subsection{Effect of lidocaine on cell viability in the BBB models}

First, the effect of lidocaine on the viability, metabolic activity and membrane integrity was studied using the hCMEC/D3 cell line and primary RBECs. Lidocaine at $1-300 \mu \mathrm{M}$ concentrations did not cause any drop in the cell impedance after $30 \mathrm{~min}$ (Fig. 3A-B). At the $1000 \mu \mathrm{M}$ lidocaine treatment concentration impedance decreased after $30 \mathrm{~min}$, but this decrease was temporary, reversible and cells recovered to the viability level of the control within $2 \mathrm{~h}$.

Incubation of the cell monolayers for $30 \mathrm{~min}$ with lidocaine in the concentration range of $1-1000 \mu \mathrm{M}$ did not cause any alteration in the metabolic activity of the cells indicating no cell damage by the MTT conversion assay (Fig. 3C-D). To determine if lidocaine damages the plasma membrane integrity LDH assay was performed. As shown in Fig. 3E-F, the release of LDH from the brain endothelial cells did not increase compared to the control. Triton X-100 detergent was used as a reference compound to elicit $100 \%$ toxicity in all the assays (Fig. 3).

\subsection{Lidocaine as a modulator of surface charge in living mammalian cells}

We hypothesized that lidocaine can change the surface charge of biological membranes which was confirmed in our measurements of zeta potential of purple membranes. To further investigate this phenomenon, we tested the effects of lidocaine on the zeta potential of living mammalian cells. In this study we used single cell suspensions from the hCMEC/D3 human brain endothelial cell line, primary RBECs and the PC-3 prostate cancer cell line with or without 10, 100 and $1000 \mu \mathrm{M}$ lidocaine treatment. The base zeta potential for all three cells types was negative, $-11.4 \pm 1.3 \mathrm{mV}$ for the hCMEC/D3 cells (Fig. 4A); $-12.3 \pm 1.2 \mathrm{mV}$ for the RBECs (Fig. 4B) and $-20.1 \pm 0.9 \mathrm{mV}$ for the PC-3 cell line (Fig. 4C). Since lidocaine is metabolized very quickly in the body by the liver, we chose the $30 \mathrm{~min}$ treatment window. The background zeta values became more positive after treatment with increasing lidocaine concentrations in the case of all three cell types (Fig. 4) proving that lidocaine interferes with the surface charge of living cells as well.

\subsection{Integrity of the BBB models after lidocaine treatment}

In clinical patients toxic side effects were only seen above $5 \mu \mathrm{g} / \mathrm{ml}$ $(21.7 \mu \mathrm{M})$ plasma concentration of lidocaine [38]. To use a clinically relevant, but not toxic concentration of lidocaine, we selected the $10 \mu \mathrm{M}$ for the barrier experiments.

The BBB restricts the movement of not only cells and large molecules, but also ions [32]. The most common method to determine the tightness of the barrier is to measure the TEER. Therefore, to investigate the effect of lidocaine on the barrier properties of the BBB models we first measured resistance. There was a three times difference between the TEER values of the BBB models showing that the primary co-culture model better restrict the movement ions as compared to the simplified BBB model (Fig. 5A-B). Lidocaine treatment $(10 \mu \mathrm{M}, 30 \mathrm{~min})$ decreased the TEER on both models. The TEER drop in hCMEC/D3 cells was 35\% ( $84 \pm 6$ to $55 \pm 10 \Omega \times \mathrm{cm}^{2}$ ) while on the triple co-culture BBB model it was only $17 \%\left(252 \pm 19\right.$ to $\left.211 \pm 6 \Omega \times \mathrm{cm}^{2}\right)$.

Since lidocaine modified the surface charge of biological membranes, we hypothesized that the permeability of charged molecules across the BBB models might also change. We used three differently charged fluorescent markers to determine their permeability across brain endothelial cells after lidocaine treatment. In the hCMEC/D3 cell line model the permeability for the water soluble negatively charged marker LY and neutral marker FD did not change as compared to the control group but the cationic molecule R123 showed an increased flux after lidocaine treatment (Fig. 5C). For the primary BBB co-culture model (Fig. 5D), also no change was observed for the LY and FD, although the $\mathrm{P}_{\text {app }}$ values of the markers were much smaller (LY: 1/10, FD: $1 / 3$ of the $\mathrm{P}_{\mathrm{app}}$ in hCMEC/D3 model) showing once more that the integrity of the barrier is stronger in the co-culture model. As compared to the cell line model the permeability of the cationic marker, R123, decreased after lidocaine treatment (Fig. 5D). This result is in accordance with our hypothesis, which presumes that the interference of lidocaine with the membrane charge decreases the permeability of a lipophilic cationic marker across the BBB if the paracellular pathway is closed.

To confirm the effects of lidocaine on brain endothelial barrier integrity, immunostainings were performed for junctional proteins $\beta$-catenin, ZO-1 and claudin-5 (Fig. 6A-B). We evaluated the subcellular expression of junctional proteins after lidocaine treatment with fluorescent intensity measurements (Fig. 6C-D). In the control groups of both BBB models the immunostainings were mainly located at the cell borders, where the cell junctions are found. RBECs showed elongated morphology with close cell-cell contacts (Fig. 6B). After $10 \mu \mathrm{M}$ lidocaine treatment a slight morphology change was visible in both models. The $\beta$-catenin showed a cytoplasmic rearrangement both in the hCMEC/D3 and the RBEC models. Similar change was observed for ZO1 in the hCMEC/D3 cells. Claudin-5 was not detectable in this cell line 
hCMEC/D3

A

Impedance $30 \mathrm{~min}$

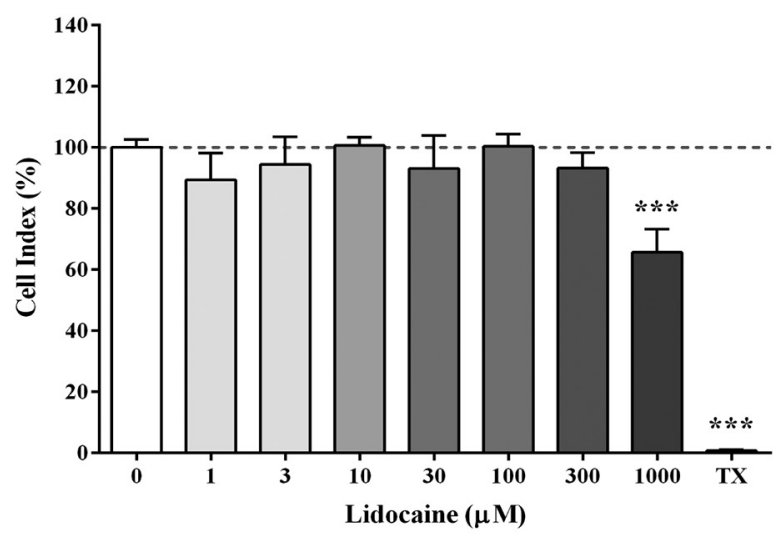

C

MTT $30 \mathrm{~min}$

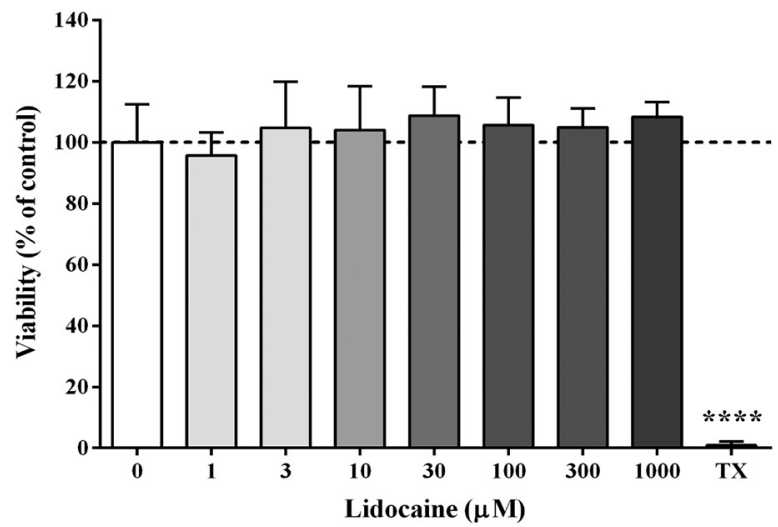

$\mathbf{E}$

LDH $30 \mathrm{~min}$

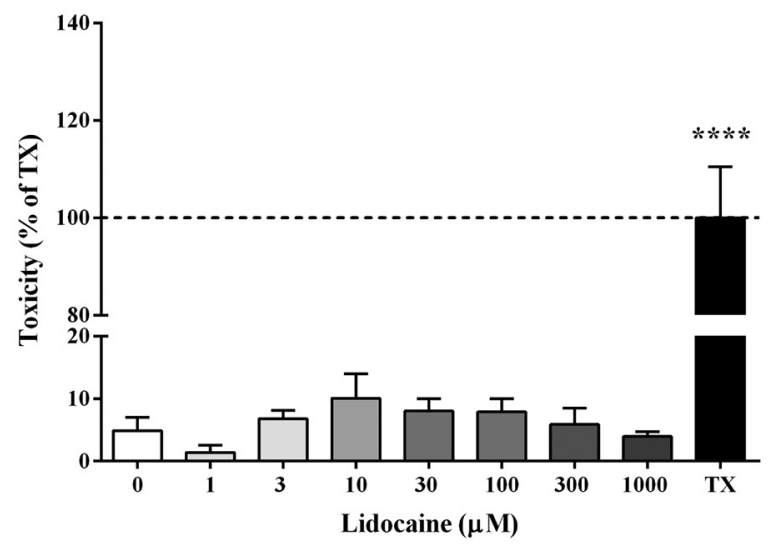

RBEC

\section{B}

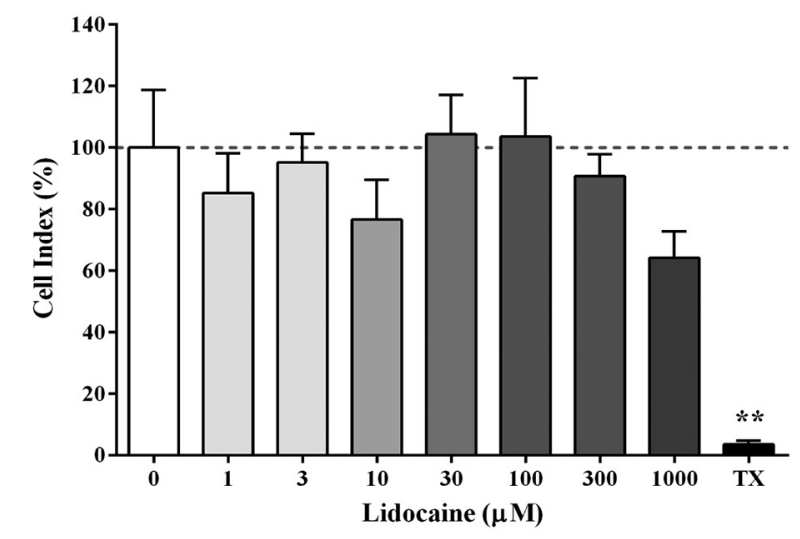

D

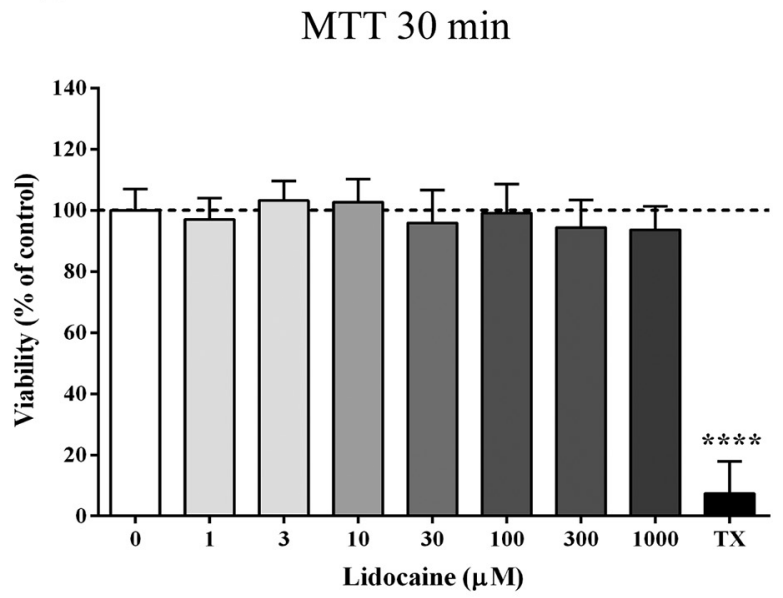

$\mathbf{F}$

LDH 30 min

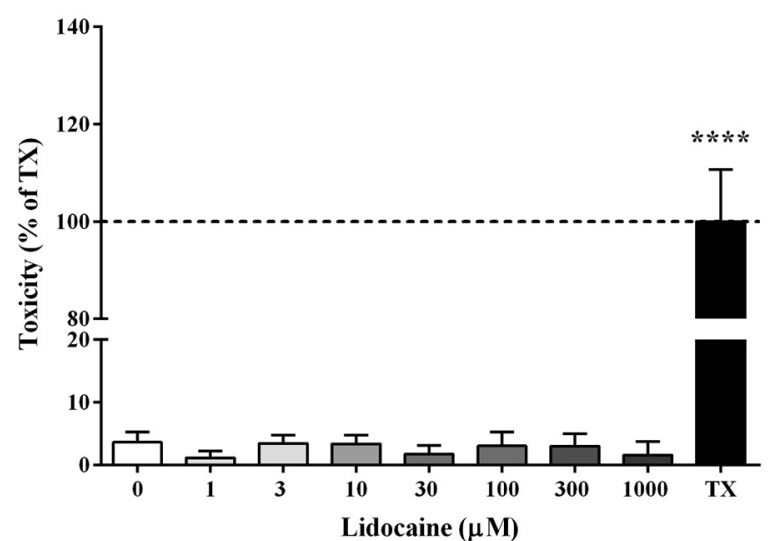

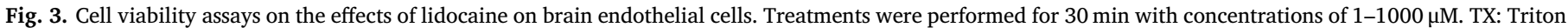

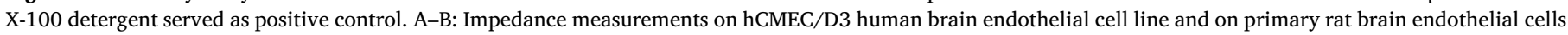

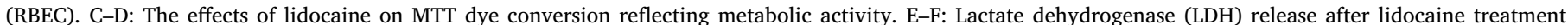

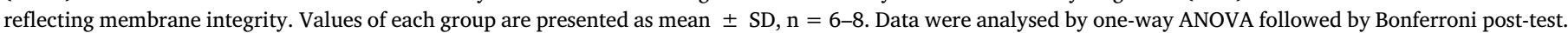
$* * * \mathrm{p}<0.001, * * * * \mathrm{p}<0.0001$ compared to the untreated control. 
$\mathbf{A}$

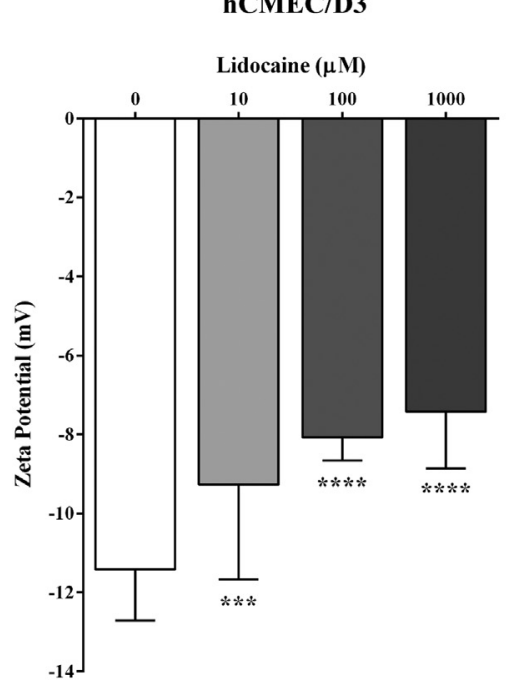

B

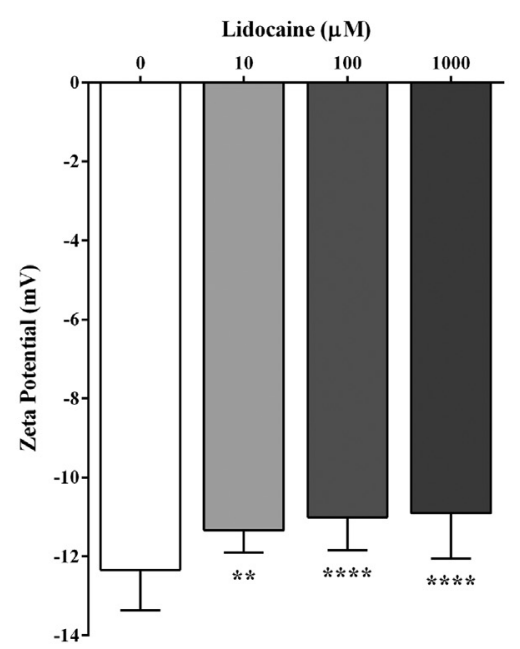

C

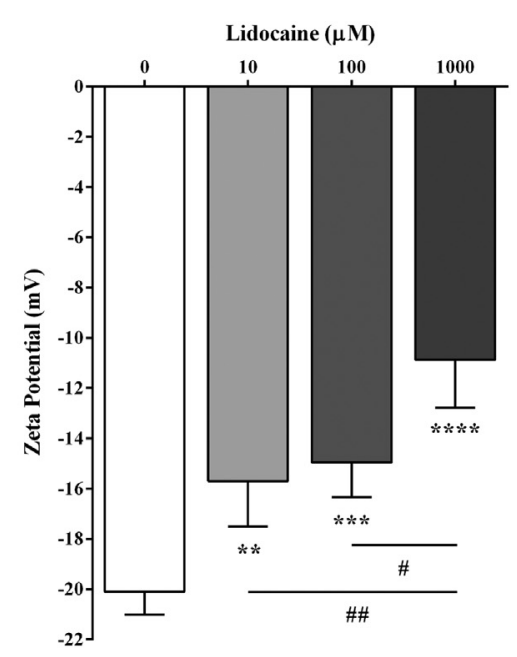

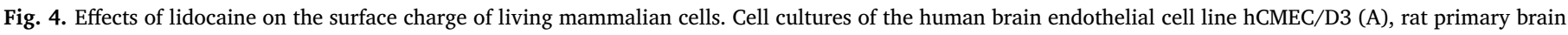

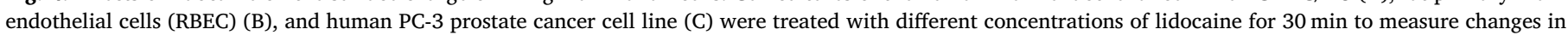

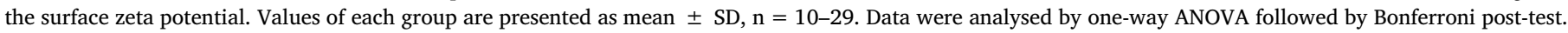
${ }^{\#} \mathrm{p}<0.05, * * ;{ }^{* \#} \mathrm{p}<0.01,{ }^{* * *} \mathrm{p}<0.001,{ }^{* * * *} \mathrm{p}<0.0001$ compared to the untreated control and between treatments.

(see Fig. S1 in Supplementary material). RBEC showed a redistribution of the claudin- 5 tight junction protein after lidocaine treatment which is also reflected by the modest TEER decrease (Fig. 5).

\subsection{Lidocaine is not an efflux pump blocker}

Since R123 is not only a positively charged lipophilic compound, but also a ligand of the Pgp efflux pump, we wanted to further investigate, whether lidocaine interferes with the activity of the Pgp function. Bidirectional permeability assay was performed, which showed that cyclosporin A by blocking Pgp increased the R123 flux in $\mathrm{AB}$ direction and decreased it in the opposite direction across the primary cell based BBB model (Fig. 7). In contrast, lidocaine treatment $(10 \mu \mathrm{M}, 30 \mathrm{~min}$ ) decreased the permeability of R123 across RBECs from the $\mathrm{AB}$ direction and did not change the flux from the $\mathrm{BA}$ direction, indicating that lidocaine does not inhibit the activity of the Pgp efflux pump.

\section{Discussion}

The BBB has special defense systems constituted by the TJs, the efflux pumps and the metabolic enzymes of brain endothelial cells $[19,39]$. This line of defense is strengthened by the negative surface charge of brain endothelial cells which regulates the entrance of charged molecules through the BBB [21,40,41], but this area is not extensively studied. In our experiments we investigated the effects of lidocaine on the surface charge of brain endothelial cells, which gets into the systemic circulation as an antiarrhythmic drug [6], and can have a direct effect on the vascular system. Previous in vivo studies have shown that lidocaine protects the BBB in high blood pressure caused barrier opening [42] or in peripheral nerve damage [43]. However, its effect on the surface charge and the barrier properties of brain microvessel endothelial cells have not yet been described. This study is the first to reveal the direct effects of lidocaine on the surface charge of biological membranes and its effects on the permeability of BBB models contributing to a wider knowledge on the interaction of cationic molecules at the level of BBB. To generalize the effects on surface charge and function, in addition to the hCMEC/D3 human brain endothelial cell line and a primary rat brain endothelial cell based culture models we also used purple membrane as a simple membrane system.
According to our hypothesis, lidocaine can influence the surface charge of the brain endothelial cell membrane and by this it can also affect BBB function.

\subsection{The effect of lidocaine on purple membranes as a simple model system}

The lipid content in the isolated purple membrane is about $25 \%$. Sulphated glycolipids are exclusively found in the purple membrane, and they are responsible for the negative charge [44]. Lidocaine treatment for $30 \mathrm{~min}$ had a direct action on the bR: a shift in both the purple membrane charge and the bR spectrum occurred (Fig. 1A and Fig. 1B). The blue color of the gels containing purple membrane was triggered by the low $\mathrm{pH}$ that also inhibits bR function (Fig. 1A). When the $\mathrm{pH}$ is low, the large amount of protons compensate the negative surface charge of purple membranes and provoke protonation of a crucial side chain of bR stopping its pumping action [15]. When lidocaine is added, it substitutes protons at the membrane surface, and allows bR to function again. The absorption spectrum and the photocycle of bR at pH 3.0 were typical for the acid blue membrane [13]. This result is similar to previous observations on deionized $\mathrm{bR}$, where the deactivation of the proton pump was achieved at $\mathrm{pH} 7$ by the removal of the divalent metal ions bound to the membrane, and the effect was reversed by cationic amine anaesthetics, including lidocaine [17]. Note, however, that in the latter caser purple color can be restored by any other common cations as well [14]. Based on the zeta potential measurements and the spectral data one can conclude that lidocaine acts as a local factor increasing the $\mathrm{pH}$ close to the membrane surface by at least 1-2 units, thereby affecting the protonation state of even buried residues of the protein. The decay of $\mathrm{O}$ intermediate, that coincides with the recovery of the initial state is nevertheless substantially slower than the recovery at neutral $\mathrm{pH}$, indicating that this step involves the direct extracellular proton release from Asp85 rather than the internal proton transfer from Asp85 to the proton release cluster. Hence the latter remains protonated during the photocycle as expected at effective $\mathrm{pH}$ values below the $\mathrm{p} K_{\mathrm{a}}=5.8$ of the proton release cluster [37].

\subsection{The effect of lidocaine on the viability of brain endothelial cells}

After we confirmed our hypothesis that lidocaine can influence the surface charge, hence the function, of a simple biological membrane, 
hCMEC/D3

A

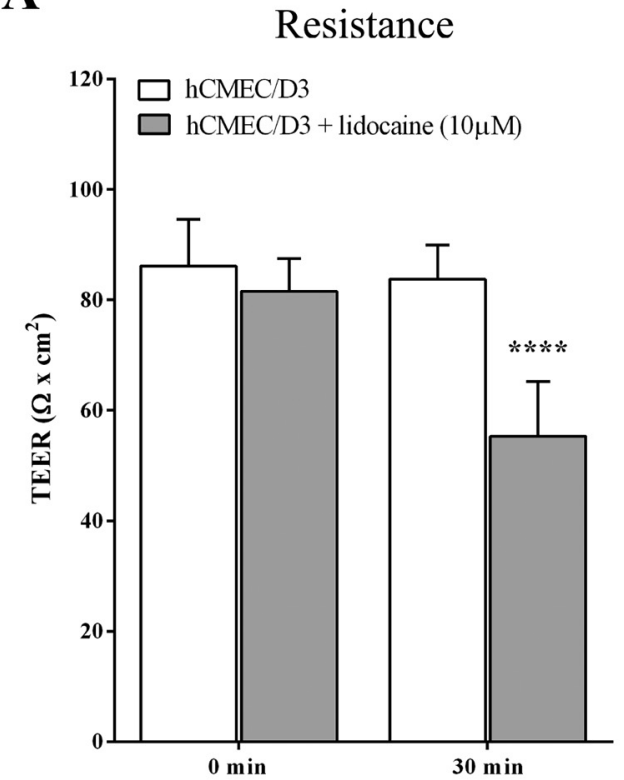

C

Permeability

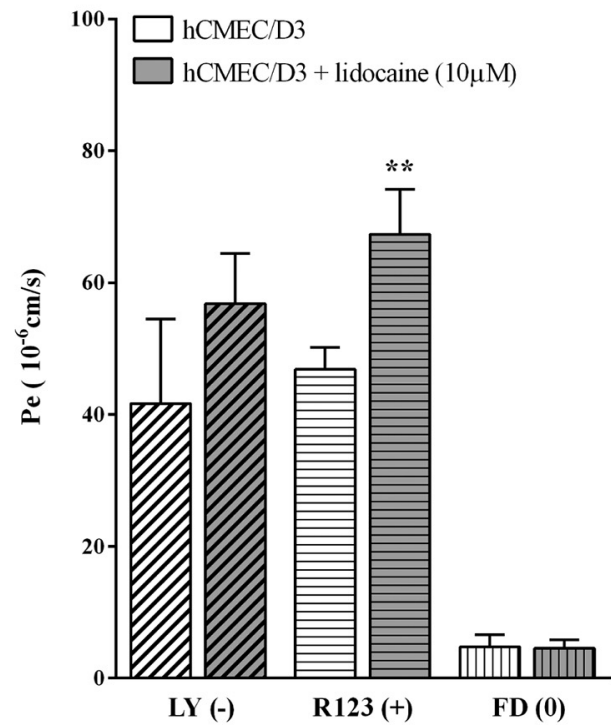

RBEC

B

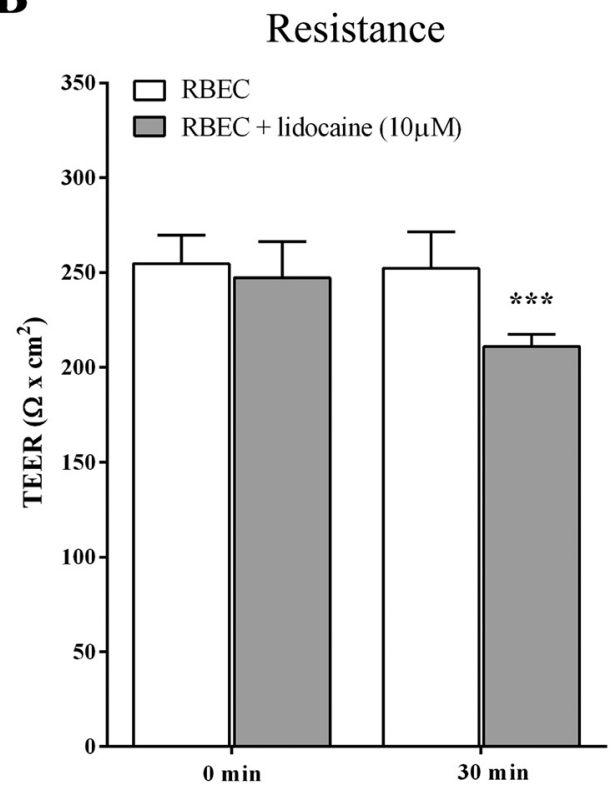

D

\section{Permeability}

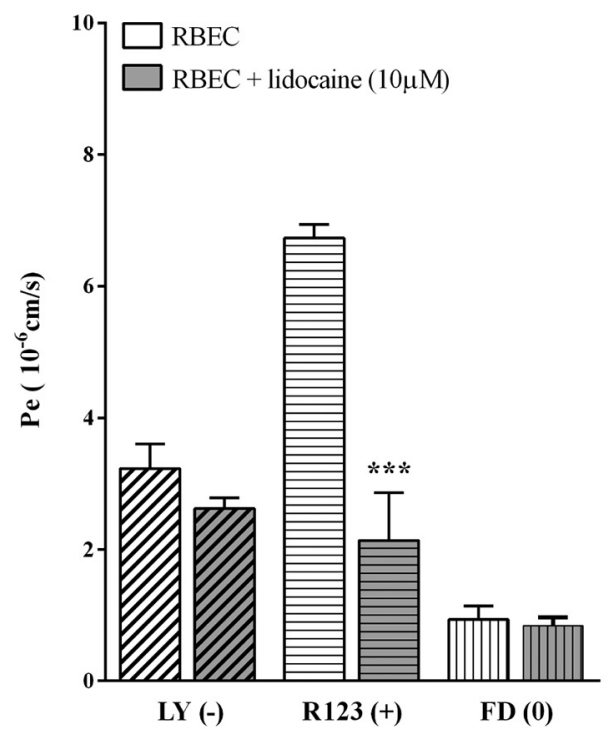

Fig. 5. Evaluation of the blood brain barrier (BBB) integrity on Transwell insert models of the BBB using hCMEC/D3 human brain endothelial cell line and rat primary cell based triple co-culture model consisting of brain endothelial cells (RBEC) with pericytes and astroglia after lidocaine treatment (10 $\mu \mathrm{M}, 30 \mathrm{~min}$ ). A and B: TEER measurements right before and $30 \mathrm{~min}$ after the lidocaine treatment. Values of each group are presented as mean $\pm \mathrm{SD}, \mathrm{n}=5-12$. Data were analysed by twoway ANOVA followed by a Bonferroni post-test. ${ }^{* * *} \mathrm{p}<0.001,{ }^{* * * *} \mathrm{p}<0.0001$, compared to the $0 \mathrm{~min}$. C and D: Endothelial permeability coefficient $\left(\mathrm{P}_{\mathrm{e}}\right)$ of cells treated with lidocaine for three differently charged tracers: Lucifer Yellow (LY, -, negatively charged), Rhodamine 123 (R123, +, positively charged) and FITCDextran (FD, 0, no charge). Values are presented as mean $\pm \mathrm{SD}, \mathrm{n}=4$. Data were analysed by unpaired t-test, where ${ }^{* *} \mathrm{p}<0.01 ; * * * \mathrm{p}<0.001$.

we were interested in the effects of lidocaine on living cells. Lidocaine is used in the pharmacotherapy as a local anaesthetic and has a clinically important role in the treatment of abnormal heart rhythm $[8,38]$. When given intravenously, it can act directly on brain endothelial cell membranes and might affect barrier properties of the BBB. To avoid the side effects of lidocaine, such as heart attack or neurologic symptoms, the concentration of the lidocaine treatment should be optimized [38]. The therapeutic plasma concentration of lidocaine is between 1.5 and $5 \mu \mathrm{g} /$ $\mathrm{ml}(6.5-22 \mu \mathrm{M})$. In order to determine the direct effect of lidocaine on the viability of brain endothelial cells, toxicity tests were performed. No change was seen in any of the assays for the tested concentrations, except for a reversible reduction of the impedance value at the highest, suprapharmacological concentration of $1000 \mu \mathrm{M}$ (Fig. 3). These data are in accordance with the low toxicity and the safe applicability of lidocaine as a therapeutic drug [6]. Since lidocaine is metabolized by the liver within $2 \mathrm{~h}$ and the half-life of the drug is short in the blood $[6,38]$, we selected the clinically relevant $10 \mu \mathrm{M}$ concentration and the 30-min treatment time to study the surface charge and barrier function of the BBB models. 
hCMEC/D3

A

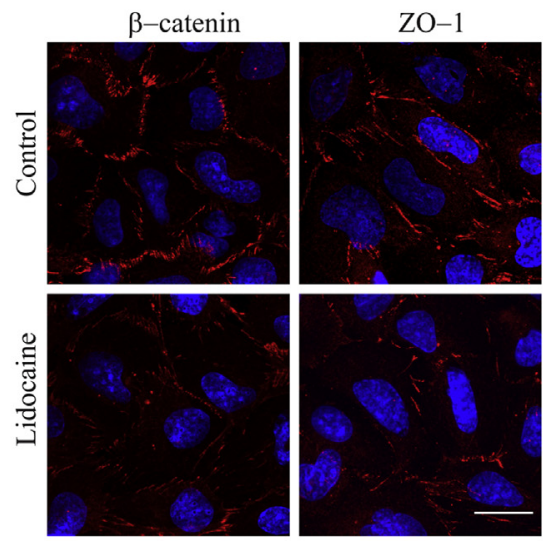

C

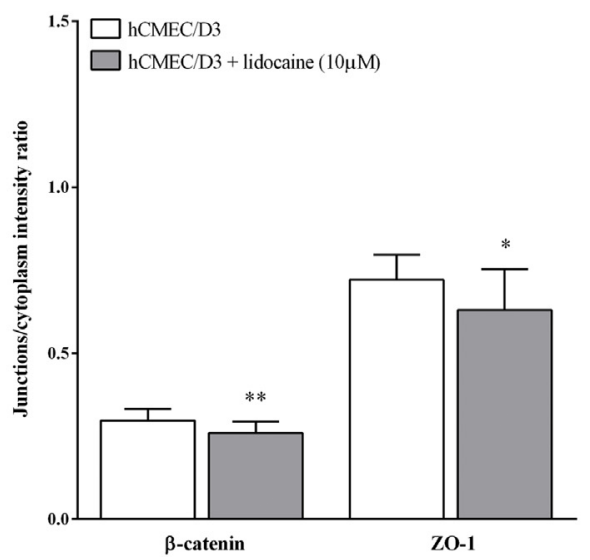

B
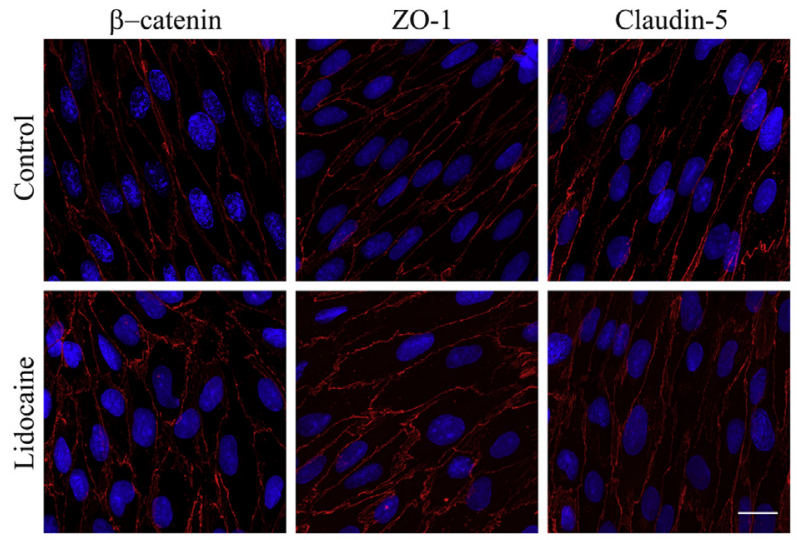

D

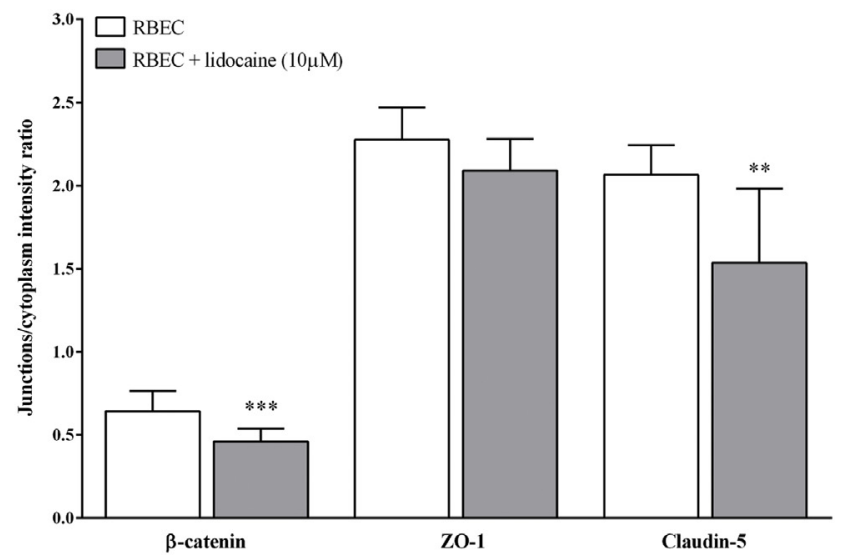

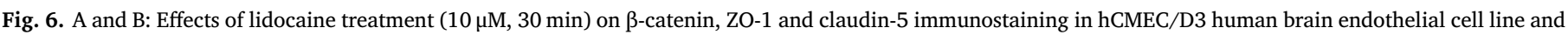

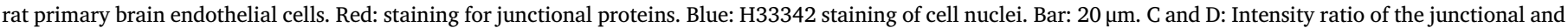

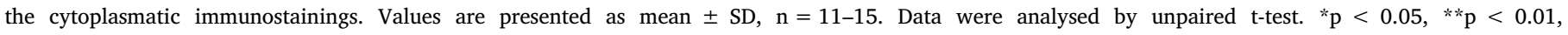
$* * * \mathrm{p}<0.001$, compared to the untreated control of the respective group.

\subsection{The effect of lidocaine on the surface charge of the brain endothelial cells}

While the hydrophobic interaction of lidocaine with the lipid bilayer of the cell membrane, including membrane fluidity, and its influence on protein channels has been studied $[8,45]$, our study is the first to measure the effect of this drug on surface charge of living cells. In the vascular system the surface charge of brain endothelial cells is more negative than that of peripheral endothelial cells [22]. This can be explained by the special lipid composition of the plasma membrane of brain microvascular endothelial cells [22] and the denser structure of glycocalyx in the luminal surface of brain capillaries [46]. In concordance with the first measurement of the zeta potential of bovine brain endothelial cell suspension [22], we also found that the surface charge of human and rat brain endothelial cells are negative and in the same range (Fig. 4). Lidocaine treatment, as we measured it on the simple model system, made the zeta values of the cells more positive, indicating a direct effect on the surface charge in both models. The surface charge elevation in mammalian cells after $1 \mathrm{mM}$ lidocaine treatment ( $\sim 40 \%$ from the control) was similar to the bR zeta potential change caused by $10 \mathrm{mM}$ lidocaine. Since treatment of bR purple membranes with the same concentration of lidocaine already resulted in a considerable color change, we suggest a similar effect in both model systems. We have also tested lidocaine on a different type of cell, a human prostate cancer cell line, and found a similar effect. Our data on lidocaine and surface charge is supported by previous findings with a cationic lipid probe, TMA-DPH. This probe, which inserts into the plasma membrane of cells, made the zeta potential of brain endothelial cells also more positive [22]. The role of the surface charge of molecules, especially cationic ones, to cross the BBB has been long known [21], but only recently measured [41]. The positively charged ibuprofen-kyotorphinamide derivative not only increased the zeta potential of brain endothelial cells, but the molecule had an increased analgesic effect in mice indicating higher penetration to brain [41].

\subsection{The effect of lidocaine on the barrier function of brain endothelial cells}

The BBB restricts the transport of substrates, from ions to large molecules, between the blood and the CNS [19]. The two major pathways for molecules and cells to cross the BBB are the paracellular (junctional) and the transendothelial routes [32,39]. The TJs are important in permeability regulation, because they not only restrict paracellular flux, but also maintain polarity of enzymes and receptors on the luminal and abluminal membrane domains [47]. The measurement of TEER is the most sensitive method to assess the tightness of TJs in BBB models [32,48]. The resistance of brain endothelial cell layers was slightly, but significantly decreased by lidocaine (Fig. 5A) suggesting an increased paracellular ionic permeability. This change was 


\section{Pgp function assay}

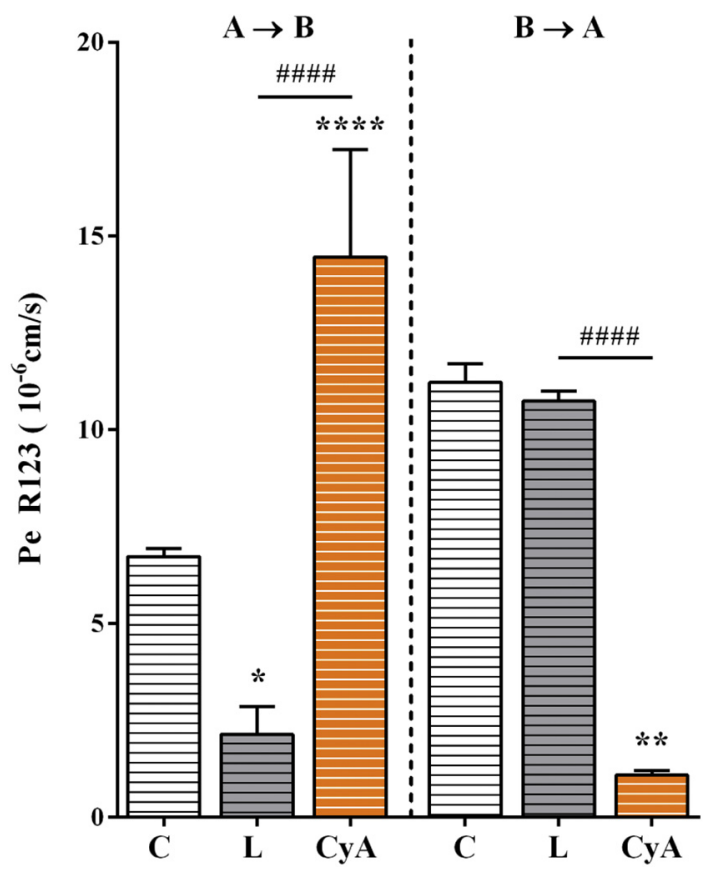

Fig. 7. Effects of lidocaine on the P-glycoprotein efflux pump activity in primary rat brain endothelial cells (RBEC). Permeability of Rhodamine 123 (R123) was measured from the abluminal to the luminal (A to B) and from the luminal to the abluminal (B to A) compartment after 30 min treatment with lidocaine or $1 \mathrm{~h}$ with P-glycoprotein pump inhibitor cyclosporin-A (CyA). Values are presented as mean $\pm \mathrm{SD} n=4$. Data were analysed by one-way ANOVA followed

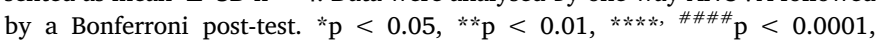
compared to the control and between groups. C: Control, L: Lidocaine.

reflected by the redistribution of the immunostaining for three junctional proteins, $\beta$-catenin, ZO- 1 and claudin- 5 in brain endothelial cells from the plasma membrane to the cytoplasm after lidocaine treatment (Fig. 6A-B) which was quantified by image analysis (Fig. 6C-D).

There was no significant difference between the control and the lidocaine treated groups in the permeability of the negatively charged and hydrophilic markers, LY and FD (Fig. 5C-D). This result indicates that lidocaine treatment affects the paracellular pathway for ions, but not for larger water-soluble molecules (for a more detailed explanation and drawings see Figs. S2 and S3 in Supplementary material). The other marker molecule, R123 is positively charged and lipophilic, therefore it crosses a tight barrier by the transcellular pathway. If the barrier is not tight, R123 is diffusing by both the trans- and the paracellular pathways. On the cell line BBB model the permeability of the R123 after lidocaine treatment was increased (Fig. 5C). This can be explained by the weaker barrier properties and the more dominant paracellular pathway of the hCMEC/D3 cell line as compared to the primary cell based BBB models $[28,48]$, and as we confirmed by the TEER data (Fig. 5A). In the case of the primary brain endothelial cell co-culture model, where TJs are tighter and the paracellular pathway is more closed, as reflected by the several fold higher TEER, the permeability of the cationic R123 was decreased by the positively charged lidocaine (Fig. 5D). We suppose that there can be a physicochemical interaction between lidocaine and R123, two positively charged molecules, at the surface of brain endothelial cells decreasing the transcellular permeability of R123 in the apical to basal direction (Fig. 8). In accordance with our data, lidocaine decreased the permeability of cationic drugs pentazocine and naloxone across the BBB in rats, but influx drug transport systems may participate in the brain uptake of these molecules $[49,50]$. We cannot exclude the possibility, that other mechanisms than membrane interactions also participate in the effect of lidocaine on BBB permeability.

Since R123 is a ligand of the Pgp efflux pump [29], one of the most important efflux transporter at the BBB $[19,48]$, we studied if lidocaine has an effect on Pgp activity. The action of lidocaine was opposite to cyclosporine A, our reference inhibitor, suggesting that it does not inhibit the Pgp efflux pump (Fig. 8). Inhibition of Pgp did not change brain/plasma concentration of lidocaine in rats [51] indicating that lidocaine does not interact with the efflux pump, in agreement with our finding.

\section{Conclusion}

Lidocaine, a cationic drug, made the surface charge of biological membranes more positive in simple model membranes and in living mammalian cells. This physical membrane effect restored the proton pump activity at acidic $\mathrm{pH}$ in purple membranes and altered the function of endothelial cells forming the barrier protecting the brain. Lidocaine increased the ionic permeability of brain endothelial cell layers, but the paracellular pathway did not change to water-soluble marker molecules. In contrast, the permeability of a cationic lipophilic marker was decreased, suggesting interaction of the cationic molecules at the membrane level. Lidocaine had no effect on the function of the Pgp efflux pump. From these data, we can conclude that lidocaine can change the surface charge, an important element of the defense function of the BBB. The more positive surface charge of brain endothelial cells does not influence the permeability of the paracellular pathway for hydrophilic molecules, but can restrict the permeability of lipophilic cationic molecules via the transcellular pathway. Our observations on one hand can help to understand the biophysical background of lidocaine action, on the other hand draw attention to the drug interactions at the level of the BBB.

\section{Transparency document}

The Transparency document associated with this article can be found, in online version.

\section{Declaration of Competing Interest}

The authors declare that they have no conflicts of interest with the contents of this article.

\section{Acknowledgments}

We would like to dedicate this work to our colleague Rudolf TóthBoconádi with whom we started this study, but who unfortunately is no longer with us.

\section{Funding}

This research work was supported by the European Training Network H2020-MSCA-ITN-2015 [Grant number 675619]; National Research Development and Innovation Office, Hungary [grant numbers GINOP-2.3.2-15-2016-00001, OTKA K-108697, NNE 129617]; F.R.W was supported by the János Bolyai Research Fellowship of the Hungarian Academy of Sciences and the National Research Development and Innovation Office, Hungary [grant number OTKA PD128480].

\section{Appendix A. Supplementary data}

Supplementary data to this article can be found online at https:// doi.org/10.1016/j.bbamem.2019.07.008. 


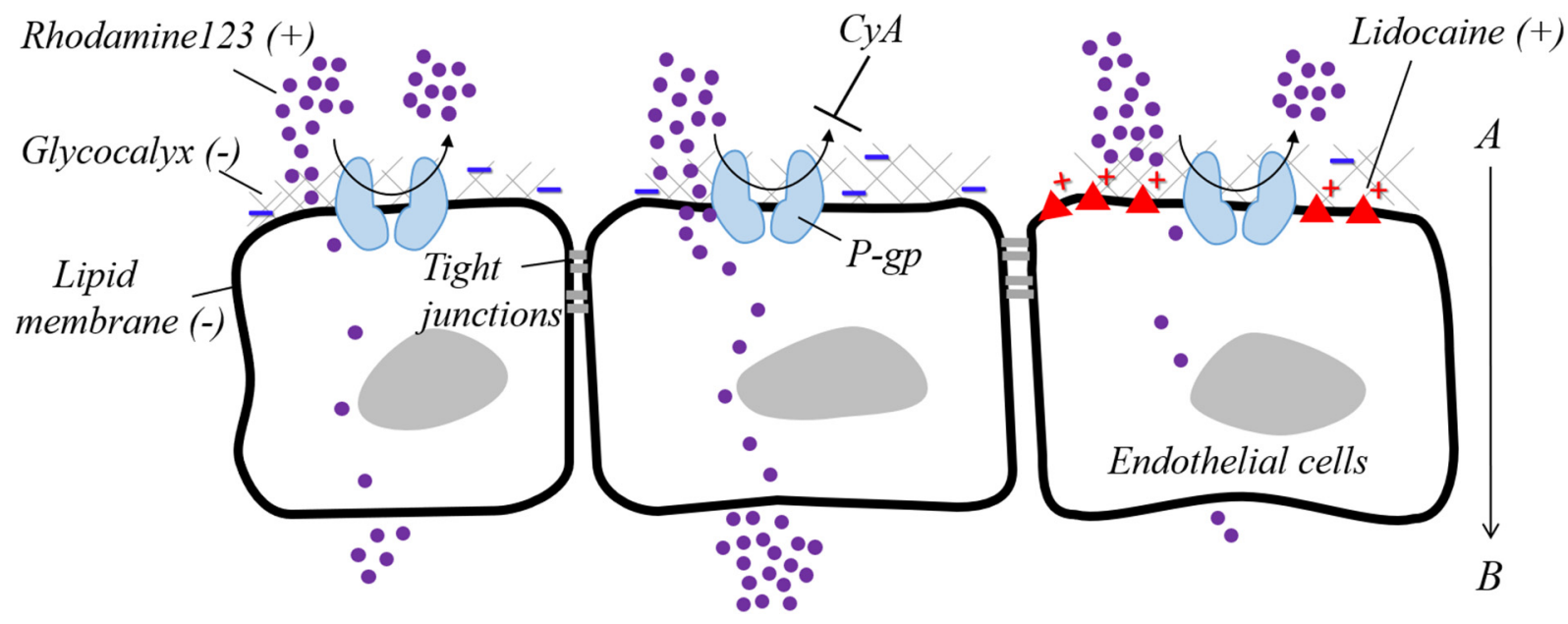

Fig. 8. A schematic figure summarizing the effects of lidocaine on cationic model molecule rhodamine 123 permeability across a tight BBB model. Rhodamine 123 under physiological conditions is pumped back to the luminal surface by the P-glycoprotein (Pgp) efflux pump, which action can be blocked by the inhibitor of the pump, cyclosporin A (CyA). Lidocaine treatment decreases the flux of rhodamine 123 through the cell layer by intercalating to the lipid bilayer and modifying the endothelial surface charge.

\section{References}

[1] L.H. Klausen, T. Fuhs, M. Dong, Mapping surface charge density of lipid bilayers by quantitative surface conductivity microscopy, Nat. Commun. 7 (2016 Aug 26) 12447.

[2] L. Wojtczak, M.J. Nałecz, Surface change of biological membranes as a possible regulator of membrane-bound enzymes, Eur. J. Biochem. 94 (1) (1979 Feb 15) 99-107.

[3] P. Seeman, The membrane actions of anesthetics and tranquilizers, Pharmacol. Rev. 24 (4) (1972 Dec) 583-655.

[4] M.P. Sheetz, S.J. Singer, Biological membranes as bilayer couples. A molecular mechanism of drug-erythrocyte interactions, Proc. Natl. Acad. Sci. U. S. A. 71 (11) (1974 Nov) 4457-4461.

[5] V.L. Baughman, C.E. Laurito, W.V. Polek, Lidocaine blood levels following aerosolization and intravenous administration, J. Clin. Anesth. 4 (4) (1992 Jul-Aug) 325-327.

[6] G.A. Dan, A. Martinez-Rubio, S. Agewall, G. Boriani, M. Borggrefe, F. Gaita, I. van Gelder, B. Gorenek, J.C. Kaski, K. Kjeldsen, L. GYH, B. Merkely, K. Okumura, J.P. Piccini, T. Potpara, B.K. Poulsen, M. Saba, I. Savelieva, J.L. Tamargo, C. Wolpert, ESC Scientific Document Group, Antiarrhythmic drugs-clinical use and clinical decision making: a consensus document from the European Heart Rhythm Association (EHRA) and European Society of Cardiology (ESC) Working Group on Cardiovascular Pharmacology, endorsed by the Heart Rhythm Society (HRS), AsiaPacific Heart Rhythm Society (APHRS) and International Society of Cardiovascular Pharmacotherapy (ISCP), Europace. 20 (5) (2018 May 1) 731-732an.

[7] H. Daykin, The efficacy and safety of intravenous lidocaine for analgesia in the older adult: a literature review, Br. J. Pain 11 (1) (2017 Feb) 23-31.

[8] H. Tsuchiya, M. Mizogami, Interaction of local anesthetics with biomembranes consisting of phospholipids and cholesterol: mechanistic and clinical implications for anesthetic and cardiotoxic effects, Anesthesiol Res Pract. 2013 (2013) 297141.

[9] N. Weizenmann, D. Huster, H.A. Scheidt, Interaction of local anesthetics with lipid bilayers investigated by ${ }^{1} \mathrm{H}$ MAS NMR spectroscopy, Biochim. Biophys. Acta 1818 (12) (2012 Dec) 3010-3018.

[10] C.J. Högberg, A.P. Lyubartsev, Effect of local anesthetic lidocaine on electrostatic properties of a lipid bilayer, Biophys. J. 94 (2) (2008 Jan 15) 525-531.

[11] B.G. Katzung, P.F. White, Local anesthetics, in: B.G. Katzung (Ed.), Basic and Clinical Pharmacology, 11th ed., Lange Medical Books/McGraw-Hill, New York, 2009, pp. 439-450.

[12] J.H. Tan, D.A. Saint, Interaction of lidocaine with the cardiac sodium channel: effects of low extracellular $\mathrm{pH}$ are consistent with an external blocking site, Life Sci. 67 (22) (2000 Oct 20) 2759-2766.

[13] D. Oesterhelt, W. Stoeckenius, Rhodopsin-like protein from the purple membrane of Halobacterium halobium, Nat New Biol. 233 (39) (1971 Sep 29) 149-152.

[14] Y. Kimura, A. Ikegami, W. Stoeckenius, Salt and pH-dependent changes of the purple membrane absorption spectrum, Photochem. Photobiol. 40 (5) (1984 Nov) 641-646.

[15] R. Renthal, K. Shuler, R. Regalado, Control of bacteriorhodopsin color by chloride at low pH. Significance for the proton pump mechanism, Biochim. Biophys. Acta 1016 (3) (1990 Apr 26) 378-384.

[16] A. Shibata, A. Yorimitsu, H. Ikema, K. Minami, S. Ueno, E. Muneyuki, T. Higuti, Photocurrent of purple membrane adsorbed onto a thin polymer film: action characteristics of the local anesthetics, Colloids Surf B Biointerfaces. 23 (4) (2002) 375-382.

[17] A. Shibata, A. Sakata, S. Ueno, T. Hori, K. Minami, Y. Baba, N. Kamo, Regeneration and inhibition of proton pumping activity of bacteriorhodopsin blue membrane by cationic amine anesthetics, Biochim. Biophys. Acta 1669 (1) (2005 May 15) 17-25.
[18] N.J. Abbott, A.A. Patabendige, D.E. Dolman, S.R. Yusof, D.J. Begley, Structure and function of the blood-brain barrier, Neurobiol. Dis. 37 (1) (2010 Jan) 13-25.

[19] M.A. Deli, Drug transport and the blood-brain barrier, in: K. Tihanyi, M. Vastag (Eds.), Solubility, Delivery and ADME Problems of Drugs and Drug Candidates, Bentham Science Publ. Ltd., Washington, DC, 2011, pp. 144-165.

[20] B.M. Fu, J.M. Tarbell, Mechano-sensing and transduction by endothelial surface glycocalyx: composition, structure, and function, Wiley Interdiscip Rev Syst Biol Med. 5 (3) (2013 May-Jun) 381-390.

[21] F. Hervé, N. Ghinea, J.M. Scherrmann, CNS delivery via adsorptive transcytosis, AAPS J. 10 (3) (2008 Sep) 455-472.

[22] M.M. Ribeiro, M.M. Domingues, J.M. Freire, N.C. Santos, M.A. Castanho, Translocating the blood-brain barrier using electrostatics, Front. Cell. Neurosci. 6 (2012 Oct 11) 44.

[23] C.J. Högberg, A.P. Lyubartsev, Effect of local anesthetic lidocaine on electrostatic properties of a lipid bilayer, Biophys. J. 94 (2) (2008 Jan 15) 525-531.

[24] H. Matsuki, M. Yamanaka, H. Kamaya, S. Kaneshina, I. Ueda, Dissociation equilibrium between uncharged and charged local anesthetic lidocaine in a surface-adsorbed film, Colloid Polym. Sci. 283 (5) (2005) 512-520.

[25] A. Dér, P. Hargittai, J. Simon, Time-resolved photoelectric and absorption signals from oriented purple membranes immobilized in gel, J. Biochem. Biophys. Methods 10 (5-6) (1985 Mar) 295-300.

[26] P. Khoroshyy, A. Dér, L. Zimányi, Effect of Hofmeister cosolutes on the photocycle of photoactive yellow protein at moderately alkaline $\mathrm{pH}$, J. Photochem. Photobiol. B 120 (2013 Mar 5) 111-119.

[27] B.B. Weksler, E.A. Subileau, N. Perrière, P. Charneau, K. Holloway, M. Leveque, H. Tricoire-Leignel, A. Nicotra, S. Bourdoulous, P. Turowski, D.K. Male, F. Roux, J. Greenwood, I.A. Romero, P.O. Couraud, Blood-brain barrier-specific properties of a human adult brain endothelial cell line, FASEB J. 19 (13) (2005 Nov) 1872-1874.

[28] S. Veszelka, A. Tóth, F.R. Walter, A.E. Tóth, I. Gróf, M. Mészáros, A. Bocsik É. Hellinger, M. Vastag, G. Rákhely, M.A. Deli, Comparison of a rat primary cellbased blood-brain barrier model with epithelial and brain endothelial cell lines: gene expression and drug transport, Front. Mol. Neurosci. 11 (2018 May 22) 166

[29] S. Nakagawa, M.A. Deli, H. Kawaguchi, T. Shimizudani, T. Shimono, A. Kittel, K. Tanaka, M. Niwa, A new blood-brain barrier model using primary rat brain endothelial cells, pericytes and astrocytes, Neurochem. Int. 54 (3-4) (2009 MarApr) 253-263.

[30] F.R. Walter, S. Veszelka, M. Pásztói, Z.A. Péterfi, A. Tóth, G. Rákhely, L. Cervenak, C.S. Ábrahám, M.A. Deli, Tesmilifene modifies brain endothelial functions and opens the blood-brain/blood-glioma barrier, J. Neurochem. 134 (6) (2015 Sep) 1040-1054.

[31] N. Perrière, P. Demeuse, E. Garcia, A. Regina, M. Debray, J.P. Andreux, P. Couvreur, J.M. Scherrmann, J. Temsamani, P.O. Couraud, M.A. Deli, F. Roux, Puromycinbased purification of rat brain capillary endothelial cell cultures. Effect on the expression of blood-brain barrier-specific properties, J. Neurochem. 93 (2) (2005 Apr) 279-289.

[32] M.A. Deli, C.S. Abrahám, Y. Kataoka, M. Niwa, Permeability studies on in vitro blood-brain barrier models: physiology, pathology, and pharmacology, Cell. Mol. Neurobiol. 25 (1) (2005 Feb) 59-127.

[33] N. Lénárt, F.R. Walter, A. Bocsik, P. Sántha, M.E. Tóth, A. Harazin, A.E. Tóth, C. Vizler, Z. Török, A.M. Pilbat, L. Vígh, L.G. Puskás, M. Sántha, M.A. Deli, Cultured cells of the blood-brain barrier from apolipoprotein B-100 transgenic mice: effects of oxidized low-density lipoprotein treatment, Fluids Barriers CNS. 12 (2015 Jul 17) 17.

[34] M.M. Domingues, P.S. Santiago, M.A. Castanho, N.C. Santos, What can light scattering spectroscopy do for membrane-active peptide studies? J. Pept. Sci. 14 (4) (2008 Apr) 394-400. 
[35] F.R. Walter, S. Valkai, A. Kincses, A. Petneházi, T. Czeller, S. Veszelka, P. Ormos, M.A. Deli, A. Dér, A versatile lab-on-a-chip tool for modeling biological barriers, Sens Actuators B Chem. 222 (2016) 1209-1219.

[37] L. Zimányi, G. Váró, M. Chang, B. Ni, R. Needleman, J.K. Lanyi, Pathways of proton release in the bacteriorhodopsin photocycle, Biochemistry. 31 (36) (1992 Sep 15) 8535-8543.

[38] R. Hilal-Dandan, B. Knollman, L. Brunton, Goodman and Gilman's the Pharmacological Basis of Therapeutics, 12 edition, McGraw-Hill Education/ Medical, 2011.

[39] N.J. Abbott, L. Rönnbäck, E. Hansson, Astrocyte-endothelial interactions at the blood-brain barrier, Nat. Rev. Neurosci. 7 (1) (2006 Jan) 41-53.

[40] G. Li, B.M. Fu, An electrodiffusion model for the blood-brain barrier permeability to charged molecules, J. Biomech. Eng. 133 (2) (2011 Feb) 021002.

[41] M.M. Ribeiro, A.R. Pinto, M.M. Domingues, I. Serrano, M. Heras, E.R. Bardaji, I. Tavares, M.A. Castanho, Chemical conjugation of the neuropeptide kyotorphin and ibuprofen enhances brain targeting and analgesia, Mol. Pharm. 8 (5) (2011 Oct 3) $1929-1940$.

[42] B.B. Johansson, L.E. Linder, Do nitrous oxide and lidocaine modify the blood-brain barrier in acute hypertension in the rat? Acta Anaesthesiol. Scand. 24 (1) (1980) 65-68.

[43] S. Beggs, X.J. Liu, C. Kwan, M.W. Salter, Peripheral nerve injury and TRPV1-expressing primary afferent C-fibers cause opening of the blood brain barrier, Mol. Pain 6 (2010 Nov 2) 74.

[44] W. Stoeckenius, R.H. Lozier, R.A. Bogomolni, Bacteriorhodopsin and the purple membrane of halobacteria, Biochim. Biophys. Acta 505 (3-4) (1979 Mar 14) 215-278.

[45] I. Yun, E.S. Cho, H.O. Jang, U.K. Kim, C.H. Choi, I.K. Chung, I.S. Kim, W.G. Wood,
Amphiphilic effects of local anesthetics on rotational mobility in neuronal and model membranes, Biochim. Biophys. Acta 1564 (1) (2002 Aug 19) 123-132.

[46] Y. Ando, H. Okada, G. Takemura, K. Suzuki, C. Takada, H. Tomita, R. Zaikokuji, Y. Hotta, N. Miyazaki, H. Yano, I. Muraki, A. Kuroda, H. Fukuda, Y. Kawasaki, H. Okamoto, T. Kawaguchi, T. Watanabe, T. Doi, T. Yoshida, H. Ushikoshi,

S. Yoshida, S. Ogura, Brain-specific ultrastructure of capillary endothelial glycocalyx and its possible contribution for blood brain barrier, Sci. Rep. 8 (1) (2018 Nov 30) 17523.

[47] M. Cereijido, R.G. Contreras, L. Shoshani, D. Flores-Benitez, I. Larre, Tight junction and polarity interaction in the transporting epithelial phenotype, Biochim. Biophys. Acta 1778 (3) (2008 Mar) 770-793.

[48] H.C. Helms, N.J. Abbott, M. Burek, R. Cecchelli, P.O. Couraud, M.A. Deli, C. Förster H.J. Galla, I.A. Romero, E.V. Shusta, M.J. Stebbins, E. Vandenhaute, B. Weksler, B. Brodin, In vitro models of the blood-brain barrier: an overview of commonly used brain endothelial cell culture models and guidelines for their use, J. Cereb. Blood Flow Metab. 36 (5) (2016 May) 862-890.

[49] T. Suzuki, Y. Moriki, H. Goto, K. Tomono, M. Hanano, J. Watanabe, Investigation on the influx transport mechanism of pentazocine at the blood-brain barrier in rats using the carotid injection technique, Biol. Pharm. Bull. 25 (10) (2002 Oct) 1351-1355.

[50] T. Suzuki, A. Ohmuro, M. Miyata, T. Furuishi, S. Hidaka, F. Kugawa, T. Fukami, $\mathrm{K}$. Tomono, Involvement of an influx transporter in the blood-brain barrier transport of naloxone, Biopharm. Drug Dispos. 31 (4) (2010 May) 243-252.

[51] T. Funao, Y. Oda, K. Tanaka, A. Asada, The P-glycoprotein inhibitor quinidine decreases the threshold for bupivacaine-induced, but not lidocaine-induced, convulsions in rats, Can. J. Anaesth. 50 (8) (2003 Oct) 805-811. 


\section{Supplementary Material}

\section{Lidocaine turns the surface charge of biological membranes more positive and changes the permeability of blood-brain barrier culture models}

Ana R. Santa-Maria ${ }^{\mathrm{a}, \mathrm{b}}$, Fruzsina R. Walter ${ }^{\mathrm{a}}$, Sándor Valkai ${ }^{\mathrm{a}}$, Ana Rita Brás ${ }^{\mathrm{a}}$, Mária Mészáros ${ }^{\mathrm{a}, \mathrm{c}}$, András Kincses $^{\mathrm{a}, \mathrm{d}}$, Adrián Klepe ${ }^{\mathrm{a}}$, Diana Gaspar ${ }^{\mathrm{e}}$, Miguel A. R. B. Castanho ${ }^{\mathrm{e}}$, László Zimányi ${ }^{\mathrm{a}}$, András Dér ${ }^{a *}$, Mária A. Deli ${ }^{\text {a* }}$

anstitute of Biophysics, Biological Research Centre, Hungarian Academy of Sciences, Temesvári krt. 62, H-6726, Szeged, Hungary

${ }^{\mathrm{b}}$ Doctoral School of Biology, University of Szeged, Hungary

${ }^{c}$ Doctoral School of Theoretical Medicine, University of Szeged, Hungary

${ }^{\mathrm{d}}$ Doctoral School of Multidisciplinary Medical Sciences, University of Szeged, Hungary

${ }^{e}$ Instituto de Medicina Molecular, Faculdade de Medicina da Universidade de Lisboa, Lisboa, Portugal

* Corresponding authors:

Mária A. Deli, E-mail: deli.maria@brc.mta.hu, Tel. +36-62-599602

András Dér, E-mail: der.andras @ brc.mta.hu, Tel. +36-62-599606 


\section{Supplementary Figure 1.}

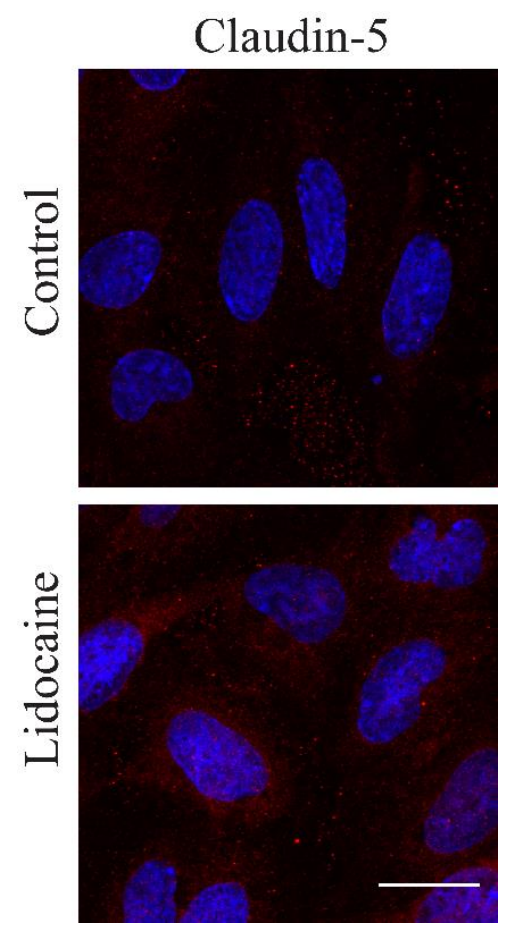

Fig. S1. Effect of lidocaine treatment $(10 \mu \mathrm{M}, 30 \mathrm{~min})$ on TJ protein claudin-5 immuno-staining in hCMEC/D3 human brain endothelial cell line. Red: staining for claudin-5. Blue: H33342 staining of cell nuclei. Bar: $20 \mu \mathrm{m}$.

No immunostaining is visible in the junctional area. 


\section{Supplementary Figure 2.}

hCMEC/D3

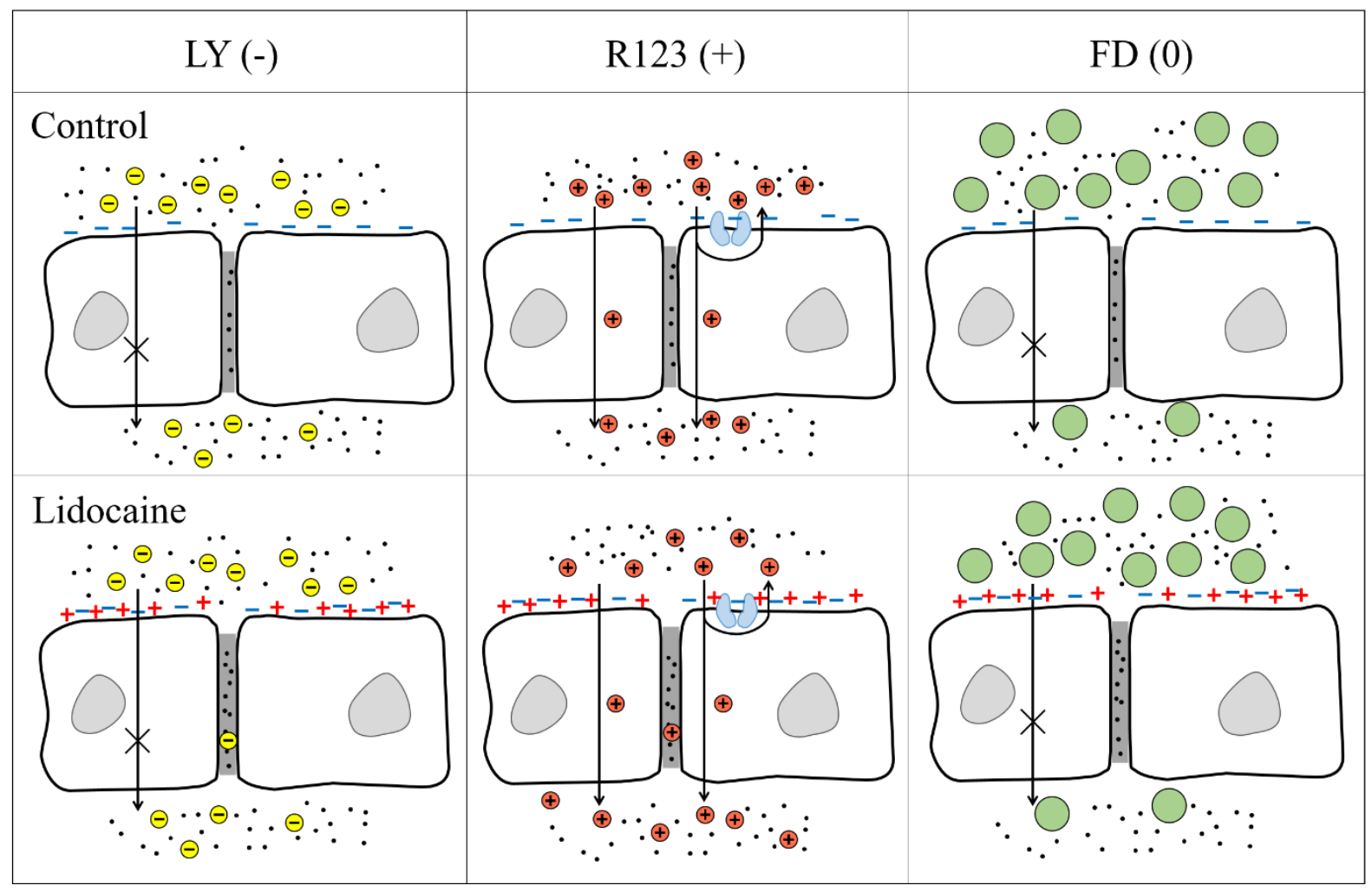

Fig S2. Drawings representing the passage of fluorescent marker molecules across the hCMEC/D3 cell culture monolayers before and after lidocaine treatment. The flux of the negatively charged marker molecule Lucifer yellow (LY, diameter $\sim 1 \mathrm{~nm}$, yellow circles); positively charged rhodamine 123 (R123, diameter $\sim 1 \mathrm{~nm}$, red circles) and neutral FITC-dextran $10 \mathrm{kDa}$ (FD, diameter $\sim 4 \mathrm{~nm}$, green circles) are indicated. Luminal surface charge is marked by blue lines: indicating negative charge and red crosses: positive charge caused by the insertion of lidocaine; Small dots: $\mathrm{Na}^{+}$ions, diameter $\sim 0.2 \mathrm{~nm}$; Light blue transporter: P-glycoprotein effux pump on the luminal side. Tight junctions between the cells are marked by grey.

The hCMEC/D3 cell line forms a less tight barrier compared to the primary cell based BBB models (Veszelka et al., 2018, PMID 29872378). This was represented by the bigger space (grey) indicating wider intercellular clefts in the cell line model (Fig. S1) as compared to the primary BBB model (Fig. S2).

Lidocaine affected the junctional permeability as measured by TEER: the flux of sodium ions (diameter $\sim 0.2 \mathrm{~nm}$ ) increased across the paracellular cleft during the measurement conditions. On Fig. S1 this change is indicated by the increased thickness of the space between cells and the higher number of sodium ions (small dots) in the paracellular cleft.

The negatively charged, water soluble Lucifer yellow (LY, median axial diameter $\sim 1 \mathrm{~nm}$ ) crosses cell layers at the interendothelial junctions, that is the reason it is considered a paracellular permeability marker. The positive charge of the lidocaine in the cell membrane is not changing the transcellular passage, because for a hydrophilic molecule this is negligible. The change in the junctional tightness is enough in the case of the small sodium ion to be detected, but for the 5-times larger LY, we can only see a trend for a higher transfer. A negligible transmembrane and restricted paracellular passage is true for the neutral marker 
FITC-dextran with a diameter of $4 \mathrm{~nm}, 20$-times bigger than that of sodium ions, resulting in no change in the transfer of the molecule even after lidocaine treatment.

In the case of the positively charged and lipophilic rhodamine 123 (diameter $\sim 1 \mathrm{~nm}$ ), there are three pathways influencing its passage: it can cross both the paracellular and transcellular routes, and in addition the P-glycoprotein efflux pump pumps back the marker to the luminal side. The hCMEC/D3 cell line expresses less Pgp than the primary BBB model (Veszelka et al., 2018, PMID 29872378). We hypothesize that the two main factors in the increased R123 flux across the cell layers are the wider tight junctions and the lower pumping efficiency of the Pgp, which is highly dependent on cell polarization caused by junctional tightness. This effect cannot be balanced by the more positive surface charge in the hCMEC/D3 cell membrane.

\section{Supplementary Figure 3.}

\section{RBEC}

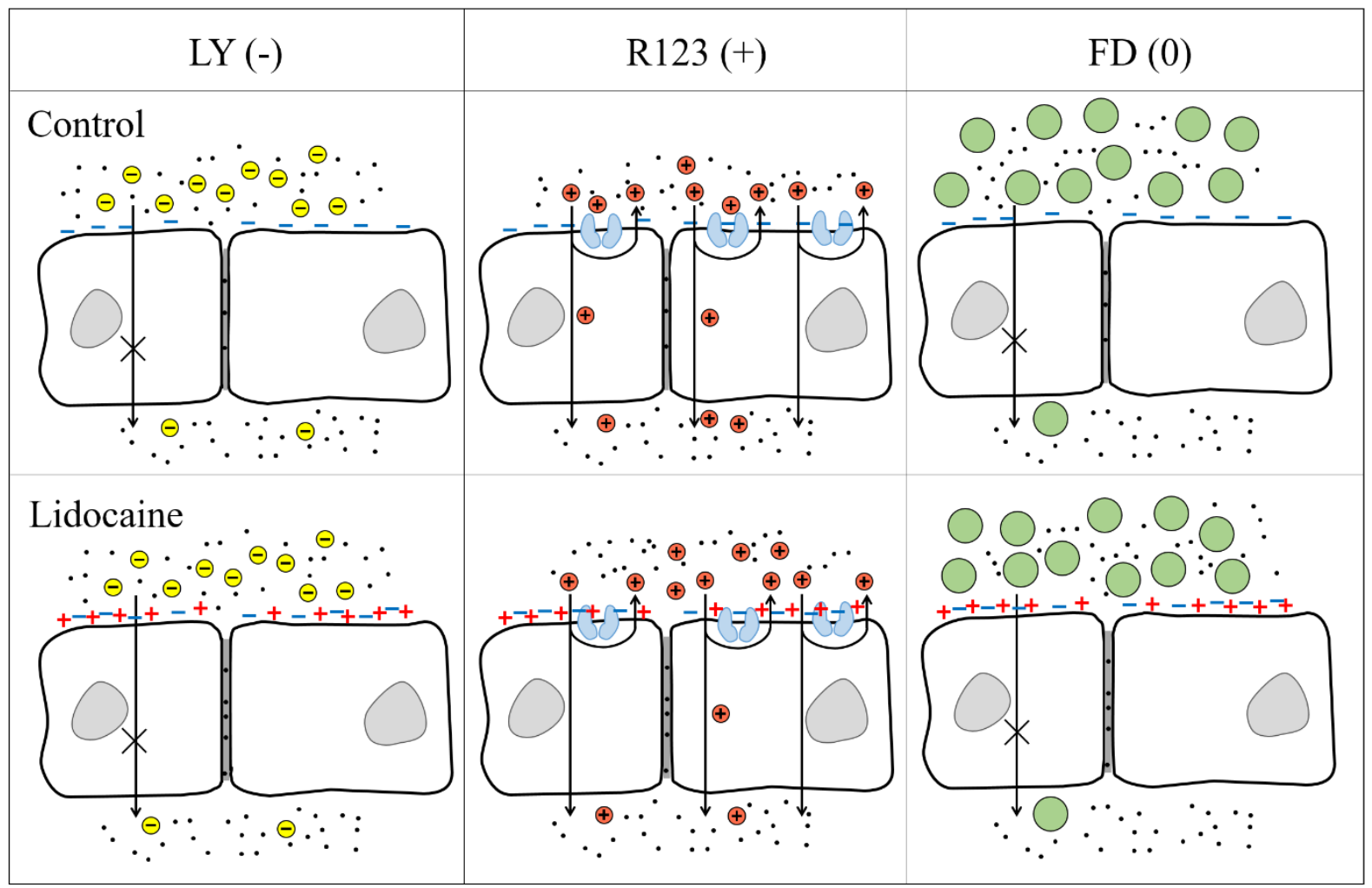

Fig S3. Drawings representing the passage of fluorescent marker molecules across primary rat brain endothelial model (RBEC) before and after lidocaine treatment. The flux of the negatively charged marker molecule Lucifer yellow (LY, diameter $\sim 1 \mathrm{~nm}$, yellow circles); positively charged rhodamine 123 (R123, diameter $\sim 1 \mathrm{~nm}$, red circles) and neutral FITC-dextran $10 \mathrm{kDa}$ (FD, diameter $\sim 4 \mathrm{~nm}$, green circles) are indicated. Luminal surface charge is marked by blue lines: indicating negative charge and red crosses: positive charge caused by the insertion of lidocaine; Small dots: $\mathrm{Na}^{+}$ions, diameter $\sim 0.2 \mathrm{~nm}$; Light blue transporter: P-glycoprotein effux pump on the luminal side. Tight junctions between the cells are marked by grey.

The primary BBB model forms a tighter paracellular barrier than the hCMEC/D3 cells (Veszelka et al., 2018, PMID 29872378) as indicated by the higher TEER and lower permeability values for all the marker molecules. This was represented by the smaller space 
(grey) between cells indicating narrower intercellular clefts in the BBB model (Fig. S2) as compared to the cell line model (Fig. S1).

The passage of the negatively charged, water soluble Lucifer yellow (LY, diameter $\sim 1 \mathrm{~nm}$ ) across the interendothelial junctional space is more restricted than in the case of the cell line. The positive charge of the lidocaine in the cell membrane does not change the transcellular passage, because for a hydrophilic molecule this is negligible. The change in the junctional tightness is enough to detect a higher sodium ion flux, but in the case of LY, with a 5-times bigger diameter, no change is seen. In the case of the neutral marker FITC-dextran (diameter: $4 \mathrm{~nm}, 20$-times bigger than that of sodium ions) a negligible transmembrane and a restricted paracellular passage result in unchanged flux of the molecule even after lidocaine treatment. In the primary BBB model two from the three pathways influencing R123 flux is different as compared to the cell line model: the paracellular route is more restricted due to the tighter junctions, and the P-glycoprotein efflux pump expression and activity are also higher (Veszelka et al., 2018, PMID 29872378). As a result, in the control condition the R123 passage across the BBB model is much lower than in the hCMEC/D3 model. Lidocaine alters the junctional cleft as measured by the increased sodium ion flux during TEER measurement, but we hypothesize that this change is not enough to increase the paracellular R123 passage based on data with LY which has a similar molecular diameter. With the Pgp pumps actively working in the BBB model, as shown by the vectorial transfer of R123, from the three pathways it is the transmembrane flux that is changed most by lidocaine. In the presence of a restricted paracellular flux and active efflux, the more positive surface charge in the membrane caused by lidocaine results in a decreased transfer of R123 due to physicochemical interference. 


\section{Publication II}




\section{Lab on a Chip}

\section{PAPER}

Check for updates

Cite this: Lab Chip, 2020, 20, 3792
Received 29th May 2020,

Accepted 4th September 2020

DOI: $10.1039 / \mathrm{dOlc00558d}$

rsc.li/loc

\section{A chip device to determine surface charge properties of confluent cell monolayers by measuring streaming potential $\uparrow$}

\author{
András Kincses, ${ }^{\text {ab }}$ Ana R. Santa-Maria, (D) ac Fruzsina R. Walter, (D) ad László Dér, ${ }^{a}$ \\ Nóra Horányi, ${ }^{a}$ Dóra V. Lipka, ${ }^{a}$ Sándor Valkai, (iD a Mária A. Deli iD *a and András Dér (iD *a
}

Cell surface charge is an important element of the function of biological barriers, but no chip device has been described to measure cell surface charge properties of confluent barrier cell monolayers. The aim of this study was the design and fabrication of a dynamic lab-on-a-chip (LOC) device which is suitable to monitor transcellular electrical resistance, as well as streaming potential parallel to the surface of cell layers. We successfully measured the streaming potential of a biological barrier culture model with the help of our previously published versatile lab-on-a-chip device equipped with two $\mathrm{Ag} / \mathrm{AgCl}$ electrodes. The inclusion of these "zeta electrodes", a voltage preamplifier and an oscilloscope in our set-up made it possible to successfully record signals describing the surface charge properties of brain endothelial cell monolayers, used as a barrier model in our experiments. Data obtained on the new chip device were verified by comparing streaming potential results measured in the LOC device and zeta potential results by the commonly used laser-Doppler velocimetry (LDv) method and model simulations. Changes in the negative surface charge of the barrier model by treatments with neuraminidase enzyme modifying the cell membrane glycocalyx or lidocaine altering the lipid membrane charge could be measured by both the upgraded LOC device and LDV. The new chip device can help to gain meaningful new information on how surface charge is linked to barrier function in both physiological and pathological conditions.

\section{Introduction}

The physical and physico-chemical parameters of mammalian cells and their outer membrane are important to determine their integrity and function. In general, plasma membranes possess an overall negative charge which is derived from sulfate and sialic acid residues of the cell surface glycocalyx and negative lipid headgroups phosphatidylserine and phosphatidylinositol of the lipid bilayer. ${ }^{1,2}$ Basic biological processes regulated by membrane charge include binding and sorting of charged proteins ${ }^{1}$ and processes like immune homeostasis and cancer cell attachment, migration and metastasis formation. ${ }^{3}$

Biological barriers are layers of tightly attached epithelial or endothelial cells specialized for the protection of the

\footnotetext{
${ }^{a}$ Institute of Biophysics, Biological Research Centre, Szeged, Hungary.

E-mail:deli.maria@brc.hu,der.andras@brc.hu

${ }^{b}$ Doctoral School of Multidisciplinary Medical Sciences, University of Szeged, Hungary

${ }^{c}$ Doctoral School of Biology, University of Szeged, Hungary

${ }^{d}$ Department of Cell Biology and Molecular Medicine, University of Szeged, Hungary

$\dagger$ Electronic supplementary information (ESI) available. See DOI: 10.1039/ dolc00558d
}

organism from the environment and special organs within the body. ${ }^{4}$ The negative surface charge of the cell layers is an important element of the defense system of barriers. The role of the negatively charged glycocalyx of the vascular endothelial barrier for example is well known in the protection of the cardiovascular system which can be damaged in diseases like atherosclerosis, ischemia due to blood vessel occlusion, diabetes, nephropathy, inflammation and sepsis. ${ }^{5,6}$ The glycocalyx of biological barriers is also important in microbiological infections: the neuraminidase enzyme of different bacteria and viruses contribute to their virulence: for example, the neuraminidase of influenza viruses, causing pandemics, facilitates virus release by cleaving sialic acid residues. ${ }^{7}$

An important inner biological barrier, the blood-brain barrier (BBB), is a complex interface separating the central nervous system and the blood circulation. Cerebral endothelial cells lining the blood vessels in the brain have very specific properties within the vascular system. ${ }^{8}$ Brain capillary endothelial cells have an inherent role in forming the gatekeeping functions of the $\mathrm{BBB}$, which consist of interendothelial tight junctions, low amount of intracellular vesicles, specialized and polarized influx and efflux transport systems. ${ }^{9,10}$ The overall negative surface charge of endothelial 
cells of brain microvessels is higher than that of other vascular endothelial cells measured by laser-Doppler velocimetry (LDv). ${ }^{2}$ On one hand, this negative charge of cerebral endothelial cells correlated with their higher phosphatidylserine and phosphatidylinositol content in the plasma membrane. ${ }^{2}$ On the other hand, the glycocalyx of cerebral endothelial cells is denser and covers larger areas of the microvessel lumen, than in the heart or lung. ${ }^{11}$ In addition, after vascular injury induced by lipopolysaccharide, the endothelial glycocalyx coverage decreased in the brain but almost completely disappeared in the peripheral organs heart and lung, indicating that the brain specific ultrastructure of the glycocalyx is an important element of the defense system of the BBB. ${ }^{11}$ This surface glycocalyx on brain endothelial cells is built from a mesh of glycolipids, sialo-glycoconjugates and heparan sulfate proteoglycans. ${ }^{12,13}$ The negative surface charge at the BBB is not only providing an extra barrier function for the brain endothelial layer, but is also important in the regulation of the passage of charged molecules including drugs, delivery vectors and nanoparticles ${ }^{12,14-17}$ across the monolayer.

Therefore, a quantitative description of the surface electric properties of cell layers forming biological barriers is essential for the broader understanding of their function in physiological processes and diseases. A well-measurable physical quantity to characterize the charge density of surfaces in contact with fluids is the so-called zeta potential. $^{18}$ Counter-ions of the liquid solution are distributed close to the charged surface of the particle, where, subject to Coulomb force and Brownian motion, form a diffuse, electric double layer. Part of the ions inside the double layer is occluded in an adsorbed layer of water molecules (the "shear layer"), which, under flow conditions, does not move with the stream. The surface potential, therefore, cannot be measured directly, only the potential difference between the surface of the shear layer and the bulk of the liquid solution, which is called zeta potential. The most widely used method to measure zeta potential of suspended particles in a solvent (colloid particles or cells in an aqueous electrolyte) is LDv, which is able to detect the electrophoretic mobility of the microscopic particles with high precision, ${ }^{19}$ from which the zeta potential can be calculated. The group of Castanho measured the zeta potential of different mammalian cells in single cell suspension by the $\mathrm{LDv}$ method and revealed that brain endothelial cells have more negative zeta potential than other types of cells or endothelial cells from other vascular bed. ${ }^{2}$ Using this technique, we have directly measured zeta potential changes in brain endothelial cells treated with lidocaine, a cationic lipophilic drug molecule and discovered that lidocaine can alter of the passage of positively charged molecules across a BBB culture model indicating possible drug interactions due to charge at the level of $\mathrm{BBB} .^{17}$

While the surface charge of individual cells can be determined by LDv, for the in situ measurement of zeta potential of biological barrier layers forming large surfaces, this method cannot be applied. Nevertheless, in the vicinity of macroscopic surfaces (e.g., when fluids are moving due to pressure difference through a channel of charged walls), a special electrokinetic technique, the streaming potential measurement can be used, instead, to determine the zeta potential at the channel wall. ${ }^{20,21}$ Streaming potential refers to the transient potential difference developing under fluid flow conditions inside the channel along the flow direction, due to the migration of mobile counter-ions from the vicinity of the charged surface of the channel. Streaming potential, measured via a pair of electrodes, is considered to be proportional to the zeta potential of the surface, under laminar flow conditions. ${ }^{20}$

Experiments to measure streaming potential in animals or in ex vivo tissues have been made since the late 60's (Table 1). Streaming potentials due to the bloodstream in rabbit aorta and vena cava were measured by microelectrodes inserted into the vessels (measurement direction parallel to the vessel surface), and the endothelial surface lining these large vessels were highly negatively charged at physiological $\mathrm{pH}^{22}$ In addition to these studies, parts of the gastrointestinal tract, namely the small intestine, ${ }^{23}$ and the buccal mucosa ${ }^{24}$ were also investigated by streaming potential measurements. In the latter case, however, the fluid flow was typically directed across the epithelial barrier layers (measurement direction perpendicular to the surface). Although, these pioneering papers have given important insight into the major role of surface charge of biological barriers in basic physiological mechanisms, with the increasing use of cell cultures in biomedical research new methods and devices are needed.

In vitro culture models of biological barriers are widely used tools for basic and applied research. ${ }^{25,26}$ In the past 10 years besides static models cultured on inserts ${ }^{26,27}$ dynamic lab-on-achip (LOC)/organ-on-chip (OC) devices were developed to study cell-cell interactions, molecular pathways, pathological conditions and drug delivery in biological barriers. ${ }^{28-31}$ These models incorporate the use of fluid flow enabling the investigation of physiological-like functions such as receptor and mechanosensor expression, transport mechanisms, pathologies and drug delivery. ${ }^{32-40}$ LOC/OC devices became important tools since they provide controlled conditions for cellular signaling and external stimulus and are able to track the development and changes in the barrier function. Specific advantages of these biochips are the possibility to monitor barrier integrity in real time, constant fluid flow to mimic blood flow and shear stress, and the opportunity of switching medium composition for treatments with the help of valves and pumps. System-integrated electrodes can be readily accommodated to LOC devices to measure the impedance spectrum ${ }^{41}$ or the trans-endothelial/ epithelial electrical resistance (TEER), ${ }^{37,42}$ to characterize the integrity of barrier-forming cellular monolayers. An alternative method to monitor cell layer integrity by high-throughput optical screening is the use of a microplate-compatible resonant waveguide grating imager. ${ }^{43,44}$ Cells in LOC/OC devices, similarly to cells cultured on inserts, can also be monitored with phase 
Table 1 Studies measuring streaming potential on tissues and cells

\begin{tabular}{|c|c|c|c|c|c|c|c|}
\hline \multicolumn{4}{|c|}{ Method to measure surface charge/zeta potential } & \multicolumn{3}{|l|}{ Tissue/cell } & \multirow[b]{2}{*}{ Ref. } \\
\hline $\begin{array}{l}\text { Streaming potential/ } \\
\text { measurement direction }\end{array}$ & $\begin{array}{l}\text { Chip } \\
\text { device }\end{array}$ & $\begin{array}{l}\text { Verification } \\
\text { by LDv }\end{array}$ & $\begin{array}{l}\text { Built in TEER } \\
\text { electrodes }\end{array}$ & Tissue/cell type & Human & $\begin{array}{l}\text { Biological } \\
\text { barrier }\end{array}$ & \\
\hline Yes/parallel & No & No & No & Aorta and vena cava & No & Yes & 22 \\
\hline Yes/perpendicular & No & No & No & Small intestine & No & Yes & 23 \\
\hline Yes/perpendicular & No & No & No & Buccal mucosa & No & Yes & 24 \\
\hline No (electro-osmosis)/parallel & No & No & No & $\begin{array}{l}\text { BGM (kidney) } \\
\text { Hep-2 (laryngeal carcinoma) } \\
\text { RPMI-1846 (melanoma) }\end{array}$ & $\begin{array}{l}\text { No } \\
\text { Yes } \\
\text { No }\end{array}$ & $\begin{array}{l}\text { Yes } \\
\text { No } \\
\text { No }\end{array}$ & 45 \\
\hline Yes/parallel & No & No & No & $3 \mathrm{~T} 12$ (fibroblast) & No & No & 46 \\
\hline Yes/perpendicular & No & Yes & No & $\begin{array}{l}\text { HEK293 (kidney epithelial) } \\
\text { EA926 (endothelial) } \\
\text { Caco-2 }\end{array}$ & $\begin{array}{l}\text { Yes } \\
\text { Yes } \\
\text { Yes }\end{array}$ & $\begin{array}{l}\text { Yes } \\
\text { Weak } \\
\text { Yes }\end{array}$ & 47,48 \\
\hline Yes/parallel & Yes & Yes & Yes & hCMEC/D3 cell line & Yes & Yes & Present model \\
\hline
\end{tabular}

contrast microscopy, while good quality immunostaining and pharmacologically relevant permeability assays are extra features in two-compartment models. ${ }^{31,37}$

Despite the recent boom in LOC devices, no biochip to determine the surface charge of intact cell layers forming biological barriers has been published, yet. Table 1 summarizes the studies in which the measurement of streaming potential of biological cell surfaces, including culture models, was investigated.

In Table 1 we refer to four studies performed on cultured cells in which cell surface charge properties were determined. ${ }^{45-48}$ One of them used electroosmosis, ${ }^{45}$ three of them streaming potential, ${ }^{46-48}$ but none of them were using an LOC device. Other differences, as compared to the present study, include the use of non-barrier forming cells ${ }^{46}$ and measurement of streaming potential across the cell layer (measurement direction perpendicular to the surface). ${ }^{47,48}$

Hence, our aim was to develop a new LOC device to directly assess the surface charge of barrier cell monolayers by applying a fluid flow parallel to the barrier surface. To achieve this goal, we added $\mathrm{Ag} / \mathrm{AgCl}$ electrodes for the detection of streaming potential under microfluidic flow conditions to our previously published LOC device, ${ }^{37}$ allowing measurement of streaming potential on a culture model of a biological barrier. With this setup, we characterized the zeta potential of a simple ionic model membrane, Nafion, and of human brain endothelial cell (BEC) monolayers as a simplified model of the BBB. LDv data and model simulations were compared to the streaming potential results and show that the zeta potential of the cell surface is proportional to the peak value of the streaming potential detected by our LOC validating measurements with the new device.

\section{Materials \& methods}

\section{LOC and electrode fabrication process}

The device was formed by top and bottom channels, separated by a porous polyester (PET) membrane with 0.45 $\mu \mathrm{m}$ pore size, $2 \times 10^{6} \mathrm{~cm}^{-2}$ pore density and $23 \mu \mathrm{m}$ thickness
(It4ip, Belgium) (Fig. 1A). The geometry of the channels enabled the measurement of trans-endothelial electric resistance (TEER) and performance of permeability assays (Fig. 1B). ${ }^{37}$ The channels were fabricated from poly(dimethylsiloxane) (PDMS, Sylgard 184, Dow Corning $\mathrm{GmbH}$, Germany) by injection molding. The length, width and height of the top and bottom channels were $36 \mathrm{~mm} \times 2$ $\mathrm{mm} \times 1 \mathrm{~mm}$ and $57 \mathrm{~mm} \times 2 \mathrm{~mm} \times 2 \mathrm{~mm}$, respectively. The initiator and base polymer were mixed in 1:10 ratio, and subsequently degassed by vacuum. The mixture was injected in brass molds that were the negatives of the channels. The PDMS was cured on $80{ }^{\circ} \mathrm{C}$ for $15 \mathrm{~min}$ to reach a rigid structure. To bind the channels to each other, the surfaces of the PDMS channels were treated with oxygen plasma. The vacuum chamber of the plasma cleaner (PDC-002, Harrick Plasma, USA) was evacuated to 200 mtorr then a steady 400 mtorr pressure was set by oxygen stream. When the 400 mtorr oxygen pressure became stable, radio frequency (RF) excitation was used for oxygen plasma treatment for 45 seconds. Thus, the PDMS channels became adhesive and could be assembled with the porous membrane between.

For the top and bottom side of the LOC device, plastic microscope slides (polystyrene, Ted Pella USA) were used. The top slide and the flat part of the male Luer lock (Rotilabo, Carl Roth, Germany) inlets/outlets were drilled with a diameter of $2 \mathrm{~mm}$ using a commercial drilling machine (Fig. 1A). The inlets were glued on the top slide using a photoresin (Norland Optical Adhesive 81, Norland Products, USA). The bottom side of the Luer locks were painted with the photoresin then placed above the holes on the top slide. After 30 seconds of exposure with a UV lamp (Newport New Illumination System, Newport Corp, USA), the resin reached the required structural rigidity. The gold electrodes for TEER measurement were formed on plastic microscope slides using sputter-coating (K975X, Emitec, France). The thickness of the gold layer was $25 \mathrm{~nm}$, providing low enough resistance ( $c a .10 \mathrm{Ohms}$ ), and approximately $70 \%$ transmission in the visible spectrum, to allow TEER measurements and simultaneous microscopic observation. ${ }^{37}$ Therefore, the cell growth could be monitored with a phase 
A

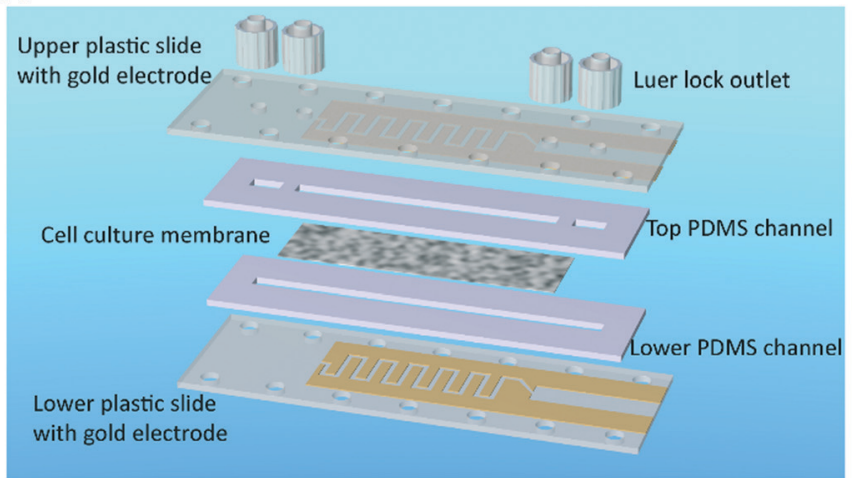

B

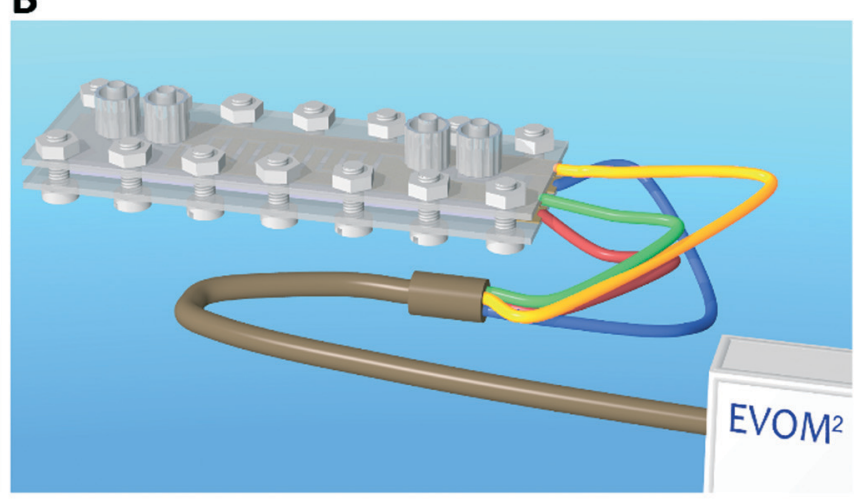

C

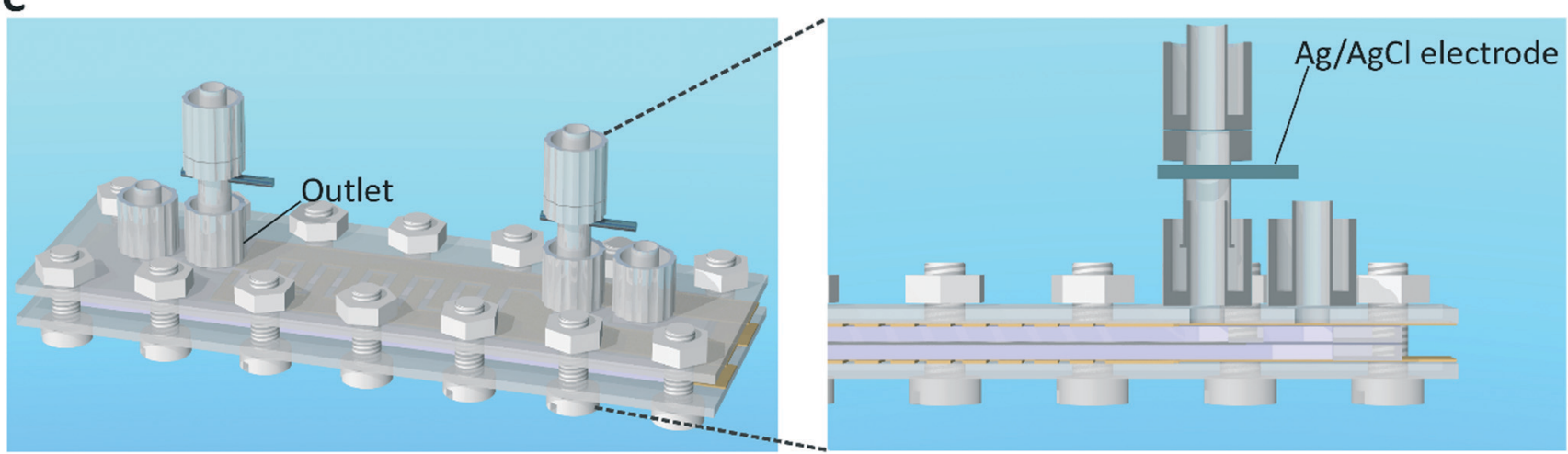

Fig. 1 The structure of the biochip. (A) The two PDMS channels are separated by a porous PET culture membrane. The top and bottom plastic slides coated with the gold electrodes are closing down the two channels. The PDMS and the plastic slides are assembled with plastic screws to avoid shortcut between the electrodes. Luer-lock inlets/outlets on the top slide provide easy access to the channels. The culture medium is circulated in the top channels, while the bottom channel is closed down using male Luer cups (not shown). (B) Copper wires are glued to gold electrodes using conductive epoxy, so the instrument $\left(\mathrm{EVOM}^{2}\right.$ ) to measure transendothelial electric resistance can be connected easily. (C) The biochip and the zeta electrodes. The PDMS channels and the plastic slides containing the electrodes for transendothelial electric resistance measurement were joined together with screws. The female Luer inlets were located on the top and provided easy access for both top and bottom channels. The $\mathrm{Ag} / \mathrm{AgCl}$ electrodes were fit in a drilled channel of male-female Luer lock caps and fixed using Norland Optical Adhesive, thus the electrodes were easy to mount to the biochip for the experiments.

contrast microscope throughout the whole length of the channel. Conductive epoxy glue (CW2400, Chemtronics) was applied in order to link copper wires to the electrodes, and a 4-channel voltohmmeter (EVOM, ${ }^{2}$ World Precision Instruments, USA) could be connected to the LOC device. The top and bottom slides and the PDMS channels were screwed together with plastic screws to avoid shortcut of the TEER electrodes (Fig. 1B, ESI $\dagger$ Video V1). The ready-to-use device was sterilized with oxygen plasma for $5 \mathrm{~min}$ and $70 \%$ ethanol for $30 \mathrm{~min}$ before cells were seeded to the system.

For the detection of streaming potentials $\mathrm{Ag} / \mathrm{AgCl}$ electrodes were prepared and placed in Luer lock connectors (Fig. 1C), so they could be easily connected to the inlet and outlet side of the biochip. The silver wires $(10 \mathrm{~mm}$ long, 0.5 $\mathrm{mm}$ width) were polished with sandpaper and washed with ethanol, then were soldered to copper wires. The connectors were drilled at their diameter, and the silver wires were fitted in. Small drops of the Norland photoresin were applied at openings between the connector and the silver cord to fix them, and were exposed to UV light using a mercury arc lamp for 30 seconds. The end of the copper wire connecting the silver was sealed with silicon glue to avoid shortcut during the subsequent electrolytic chloridisation. For this, the wires were immersed in $3 \mathrm{M} \mathrm{KCl}$ solution, one at the time, and a 3 mA DC current was applied for 1 minute. The ready $\mathrm{Ag} / \mathrm{AgCl}$ electrodes were rinsed with distilled water and dried under N2.

\section{Cell culture}

To model the BBB, the hCMEC/D3 human brain endothelial cell line was used (Merck, Germany). ${ }^{49}$ Cell cultures ( $\leq$ passage 35 ) were kept in MCDB 131 medium (Pan Biotech) supplemented with $5 \%$ fetal bovine serum (FBS, Sigma), Glutamax (100×, Life Technologies, USA), lipid mixture (100×, Life Technologies, USA), $10 \mu \mathrm{g} \mathrm{ml}^{-1}$ ascorbic acid, $550 \mathrm{nM}$ hydrocortisone, $100 \mu \mathrm{g} \mathrm{ml}^{-1}$ heparin, $1 \mathrm{ng} \mathrm{ml}^{-1}$ human basic fibroblast growth factor (bFGF, Roche, USA), insulin (2.5 $\mu \mathrm{g}$ $\left.\mathrm{ml}^{-1}\right)$, transferrin $\left(2.5 \mu \mathrm{g} \mathrm{ml}^{-1}\right)$, sodium selenite $\left(2.5 \mathrm{ng} \mathrm{ml}^{-1}\right)$ provided as a mix (ITS, Life Technologies, USA), and $50 \mu \mathrm{g}$ 
$\mathrm{ml}^{-1}$ gentamicin. Membranes in the LOC device were coated with $0.5 \%$ gelatin from porcine skin (Sigma) and incubated at $37^{\circ} \mathrm{C}$ for $20 \mathrm{~min}$. hCMEC/D3 cells were seeded at a number of $1 \times 10^{5}$ into the device. On day 4 cells received $\mathrm{LiCl}(10 \mathrm{mM})$ to elevate barrier tightness. ${ }^{27}$ As described in our previous work, cell cultures were kept for 3 days under static conditions in the device. ${ }^{37}$ A syringe $(20 \mathrm{ml}$ plastic disposable syringe with Luer cone, Braun) containing the culture medium was placed in a syringe pump (Legato 110, KDS products, USA) and connected to the device. The tubes (1 $\mathrm{mm}$ inner, $3 \mathrm{~mm}$ outer diameter, Carl Roth, Germany) were connected to the inlets/outlets via female Luer-locks (Rotilabo, Carl Roth, Germany) to allow feeding during cell growth and constant medium-supply. During the cell growth phase, the syringe pump was programed to change the medium above the cell monolayer (static condition) with 500

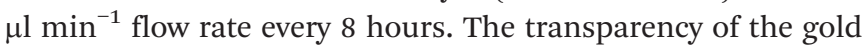
electrodes lets us monitor the growth of the cell monolayer by phase contrast microscopy on the entire surface, and TEER was measured every day. If the cell layer was not continuous as reflected in low TEER values and visually detected holes, the device was excluded from the experiments. Before the cell layer reached full confluence, a constant stream of culture medium was introduced by a peristaltic pump (Masterflex, Cole-Parmer, USA) for 24 hours ( $1 \mathrm{ml} \mathrm{min}^{-1}$, flow condition) before zeta measurement and permeability studies.

\section{Cell culture treatments}

Lidocaine (Sigma L7757) was dissolved in water at $30{ }^{\circ} \mathrm{C}$ to prepare a $20 \mathrm{mM}$ stock solution. Working solutions of $1 \mathrm{mM}$ concentration were prepared freshly before each experiment in culture medium and added to the cells. ${ }^{17}$ Neuraminidase from Clostridium perfringens (Sigma N2876) was dissolved in Dulbecco's modified Eagle's medium (DMEM) and aliquots of a $10 \mathrm{U} \mathrm{ml}^{-1}$ stock were stored at $-20{ }^{\circ} \mathrm{C}$. A new neuraminidase stock vial was thawed before each experiment. For the treatment neuraminidase was applied at 0.1, 0.3 and $1 \mathrm{U} \mathrm{ml}^{-1}$ concentrations to the cells based on a preliminary study and literature data. ${ }^{50}$

\section{Zeta potential measurements: detection of streaming potential}

Development of streaming potential is a well-known electrokinetic phenomenon occurring in microfluidic channels. $^{51,52}$ If the inner surface of the channel is covered with charges (intrinsic or adsorbed), it attracts counterions from the solution, and keeps them near the surface. Due to a balance of Coulomb attraction and Brownian motion, a diffuse double layer is formed by the mobile ions and the fixed surface charges, the Gouy-Chapman layer (GCL). As a consequence, an electric potential gradient develops perpendicular to the membrane plane, screening the surface potential of the membrane across the GCL. If fluid flow is applied in the channel, a major part of the counterion cloud of GCL, divided by a "slipping plane" to a moving part and a layer sticking the channel wall, will be grabbed by the solution under Poiseuille flow. The resulting flow of net charge along the channel represents an electric current called streaming current, and the accompanying streaming potential can be detected by an electrode pair separated alongside the channel. The streaming potential under stationary conditions is proportional to the surface potential of the shear plane called zeta potential, according to the Helmholtz-Smoluchowski equation. ${ }^{18}$ Since the zeta potential can be relatively easily measured by electrokinetic methods, this is the very quantity that is used to characterize surface charge densities of artificial membranes or colloid particles. In this work, we measure a nonstationary (transient) streaming potential, in order to maximize the signal amplitude by applying high inlet flow rates. We provide both theoretical and experimental evidence that the amplitude of the transient signal is proportional to the zeta-potential at the surface, in this case, too (for more details, see below, and under the Simulation section).

The transient signal was gained and filtered with a lownoise voltage pre-amplifier (SR560, Stanford Research Systems, USA) (Fig. 2A), recorded by a digital oscilloscope (Wave Ace, Teledyne LeCroy, USA), and further analyzed via the Wavestudio software (Teledyne LeCroy, USA). The amplitude of the transient streaming potential signals was calculated with Matlab (MathWorks, USA). The difference between the baseline and the maximum of the curve defined the amplitude. The noise of the signals was eliminated with the function estimation of smoothing splines (Fig. 3A).

Experimental validation of the system was performed by using a Nafion membrane (Ion Power, USA) inserted between the two PDMS channels. For the measurements performed on the confluent monolayer of hCMEC/D3 after $24 \mathrm{~h}$ flow, first, the background streaming potential was registered under a $1 \mathrm{ml} \mathrm{min}^{-1}$ flow rate, then cells were treated with 1 $\mathrm{mM}$ lidocaine for $30 \mathrm{~min}$ at $37^{\circ} \mathrm{C}$ or with $1 \mathrm{U} \mathrm{ml}^{-1}$ neuraminidase in a serum-free medium for $1 \mathrm{~h}$ at $37^{\circ} \mathrm{C}$. After treatments, streaming potential was measured again with the same electrodes and under the same conditions, and changes were calculated. In case of cell monolayers in the control group, instead of any treatment, the medium was changed and incubated for $30 \mathrm{~min}$ or $1 \mathrm{~h}$ at $37^{\circ} \mathrm{C}$, before the streaming potential was measured.

\section{Zeta potential measurements: laser-Doppler velocimetry}

LDv measures the electrophoretic mobility of charged particles with two collimated, monochromatic, and coherent laser light beams, forming a set of straight fringes by interference. ${ }^{19}$ The moving particles go through the fringes and reflect light to a photodetector. The frequency of the reflected light's intensity fluctuation is proportional to the Doppler shift between the scattered and incident light, and the velocity of the particles is proportional to the Doppler shift. Using the Smoluchowski equation the zeta potential $\zeta$ can be calculated as follows: 


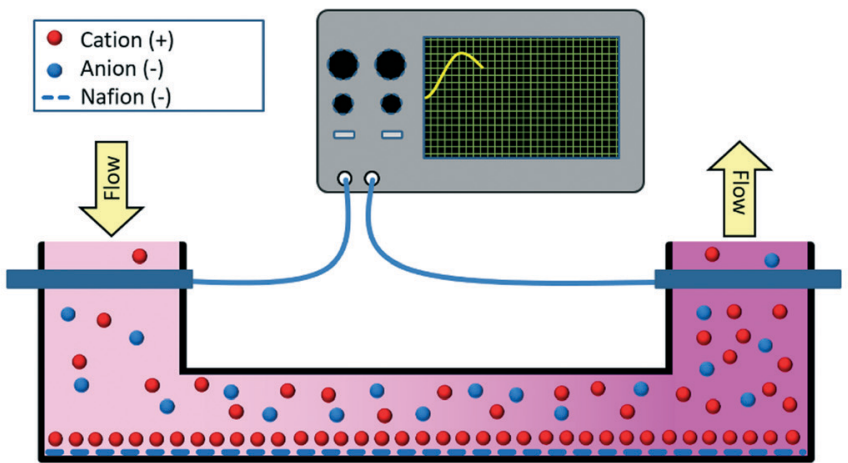

\section{B Laser-Doppler Velocimetry}

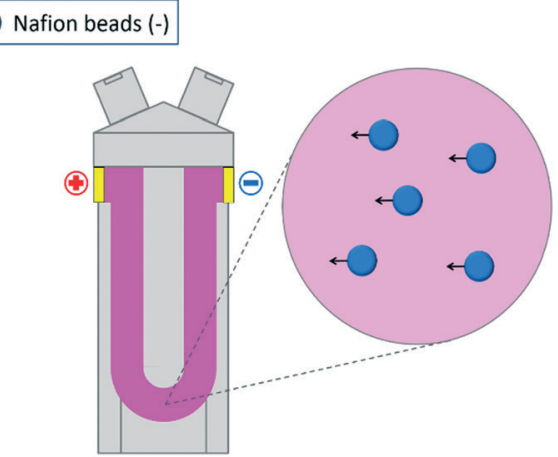

Fig. 2 Methods of zeta potential measurement. (A) Streaming potential. The counterions of the solution has a higher local concentration close to the negatively charged surface due to the electric double layer. The ion concentration of the diffuse layer was constant (fix cations close to the surface) while the cations of the slipping plane move towards the outlet under flow conditions and temporarily accumulate in the larger vicinity of the electrode resulting in a potential difference compared to the reference (inlet) electrode. (B) Laser-Doppler velocimetry. Electric field was applied on a suspension of charged particles (e.g. the Nafion beads) in the capillary channel and the beads moved toward the direction of the field. The electrophoretic mobility is measured with the intensity shift between two collimated, monochromatic, and coherent laser beams, thus the zeta potential of the particles can be calculated.

A

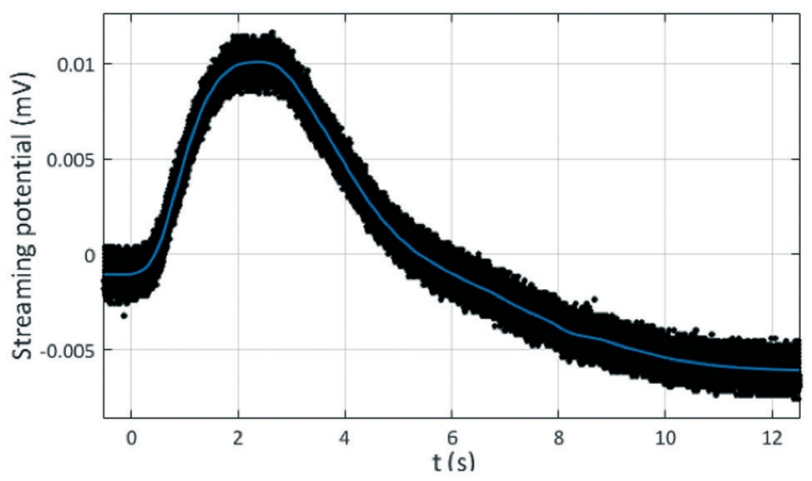

B

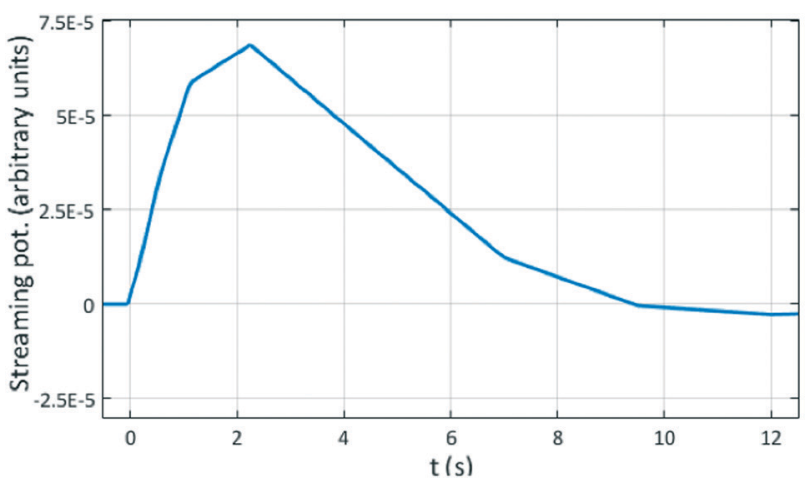

Fig. 3 Comparison of the registered streaming potential and the model simulations. In both cases the reference was on the lowpressure end so the positive potential difference corresponds to negative zeta potential since it measured the concentration of the counterions. (A) The registered signal on Nafion membrane measured in the biochip. (B) The result of the simulation. The streaming potential is shown in arbitrary units because the geometry of the model was proportionally decreased as compared to the chip device. The dynamics of the transient streaming potential signal is identical.

$$
\xi=\frac{4 \pi \mu \eta}{\varepsilon}
$$

where $\mu$ is the electrophoretic mobility, $\eta$ is the viscosity of the solvent and $\varepsilon$ is the dielectric constant.

In the experiments a Zetasizer Nano ZS instrument (Malvern, UK) was used. First, LDv was performed using Nafion beads (Ion Power, USA) as a simple model for ionic surface changes. Nafion belongs to a class of polymers with ionic properties, which unique characteristic results from the incorporation of perfluorovinyl ether groups terminated with sulfonate groups onto a tetrafluoroethylene strength. ${ }^{53}$ To alter the negative surface charge of the Nafion particles cationic polyethylenimine (PEI) polymer with good attachment properties was used. Nafion beads were stored in a mixture of water and ethanol. To measure the LDv of the Nafion beads they were transferred into the same ionic solution used for measuring the surface charge of endothelial cells. First, $2 \times 1 \mathrm{ml}$ Nafion stock solution was spun down with ultracentrifugation (T-1270 fixed angle titanium rotor, Sorvall WX+100 ultracentrifuge, ThermoFisher Scientific, USA) at $45000 \mathrm{rpm}$ for $30 \mathrm{~min}$ on $4{ }^{\circ} \mathrm{C}$. The pellet in one of the vials was resuspended in $2 \mathrm{ml}$ phosphate-buffered saline (PBS) solution containing $\mathrm{Ca}^{2+}$ and $\mathrm{Mg}^{2+}$, while the other vial was resuspended in $3 \mathrm{ml}$ PEI. Both samples were sonicated for $60 \mathrm{~min}$. The PEI-treated sample was ultracentrifuged once more with the same settings and was resuspended in $2 \mathrm{ml}$ of PBS containing $\mathrm{Ca}^{2+}$ and $\mathrm{Mg}^{2+}$ and sonicated for 1 hour. This step was repeated once more to remove any PEI which was not attached to the Nafion beads. Samples were measured by Zetasizer Nano ZS using a disposable zeta potential cuvette with gold plated beryllium/copper electrodes (DST1070, Malvern, UK). Before measurements cuvettes were rinsed with $100 \%$ ethanol for activation and washed twice with 
distilled water. Then zeta cuvettes were calibrated with zeta standard solution (Malvern, UK) as described by the manufacturer's protocol. Samples were measured at $25{ }^{\circ} \mathrm{C}$, with a minimum of 6 rounds (12 runs each), with an applied $40 \mathrm{~V}$ voltage (Fig. 2B).

Zeta potential of hCMEC/D3 brain endothelial cells was measured similarly. ${ }^{17}$ Before the cells in Petri dishes reached full confluence were trypsinized and $10^{5}$ cells were resuspended for treatment in the appropriate buffer. As described in our previous work, $1 \mathrm{mM}$ lidocaine was added to the cell suspension and incubated at $37{ }^{\circ} \mathrm{C}$ for $30 \mathrm{~min} .{ }^{17}$ For neuraminidase treatment, cells in suspension were incubated with $1 \mathrm{U} \mathrm{ml}^{-1}$ of neuraminidase in a serum-free medium for $1 \mathrm{~h}$ at $37^{\circ} \mathrm{C}$ before measurement. The Zetasizer software v.7.12. calculated the zeta potential using the Smoluchowski equation.

\section{Evaluation of barrier integrity}

hCMEC/D3 cultured in the LOC device received fresh medium every 8 hours automatically, and TEER measurement was performed each day to follow barrier formation. After the $48 \mathrm{~h}$ flow in the device treatments followed by permeability measurements were done to determine the integrity of the cell layers. Permeability for fluorescein isothiocyanate-labeled $10 \mathrm{kDa}$ dextran (FD10, Sigma) was done as described previously. ${ }^{37}$ In the lower compartment the cell culture medium was changed to Ringer-Hepes buffer (118 mM NaCl, $4.8 \mathrm{mM} \mathrm{KCl,} 2.5 \mathrm{mM} \mathrm{CaCl}_{2}, 1.2 \mathrm{mM} \mathrm{MgSO}$, $5.5 \mathrm{mM}$ D-glucose, $10 \mathrm{mM}$ Hepes, at $\mathrm{pH}$ 7.4) supplemented with $1 \%$ FBS and 1\% ITS. In the upper compartment of the device the culture medium was changed for Ringer-Hepes containing $10 \mu \mathrm{g} \mathrm{ml}^{-1}$ FD10 for control biochips, and RingerHepes containing $10 \mu \mathrm{g} \mathrm{ml}^{-1} \mathrm{FD} 10$ and $1 \mathrm{mM}$ lidocaine in the lidocaine treatment group. For the neuraminidase treatment cell culture medium was replaced for serum-free medium containing $1 \mathrm{U} \mathrm{ml}^{-1}$ of neuraminidase and incubated for $1 \mathrm{~h}$ at $37{ }^{\circ} \mathrm{C}$. After streaming potential was measured, permeability measurement was done replacing the cell culture medium as described above. The devices were kept in a $\mathrm{CO}_{2}$ incubator, on a horizontal shaker (150 rpm), for 30 min during permeability measurements, then samples were collected from both compartments of the device and concentrations of the molecular marker were measured by fluorescent spectrophotometry (Fluostar Optima, BMG Labtechnologies, Germany) with $485 \mathrm{~nm}$ excitation and 520 $\mathrm{nm}$ emission wavelengths. Apparent permeability coefficient $\left(P_{\text {app }}\right)$ was calculated as described previously. ${ }^{54}$

\section{Fluorescent immunostaining}

Permeability measurements were followed by immunohistochemical stainings for morphological characterization. ${ }^{17}$ Brain endothelial cells were fixed with cold acetone-methanol solution $(1: 1)$ for $2 \mathrm{~min}$, washed with PBS and stained for junctional associated protein $\beta$-catenin. To block the non-specific binding sites cells were incubated with $3 \%$ bovine serum albumin (BSA) in PBS for $1 \mathrm{~h}$ at room temperature. Incubation with the primary antibody polyclonal rabbit anti- $\beta$-catenin (Sigma, C2206; $1: 200$ ) lasted overnight at $4{ }^{\circ} \mathrm{C}$. The next day cell culture membranes were incubated with secondary antibody anti-rabbit labeled with Cy3 (Sigma C2306; $1: 400$ ) and bis-benzimide H33342 (Merck, Germany) for nucleus staining, for $1 \mathrm{~h}$ at room temperature. Between incubations membranes with cells were washed three times with PBS. Pictures for the junctional staining were visualized by a Leica TGS SP5 confocal laser scanning microscope (Leica Microsystems, Germany).

\section{Surface glycocalyx staining}

Endothelial cells were cultured on rat tail collagen coated glass cover slips. After reaching confluence cells were treated either with culture medium (control group) or with neuraminidase as described in the Cell culture treatment section. After treatment cells were fixed with $1 \%$ paraformaldehyde in PBS for $15 \mathrm{~min}$ at room temperature. To visualize the surface glycocalyx fixed but unpermeabilized cells were incubated with wheat germ agglutinin (WGA) lectin conjugated with Alexa Fluor 488 (Invitrogen, W11261). WGA is specific for sialic acid and $N$-acetyl-D-glucosamine residues within the glycocalyx. The final concentration of WGA was 5 $\mu \mathrm{g} \mathrm{ml} \mathrm{m}^{-1}$ in PBS and the incubation lasted for $10 \mathrm{~min}$ at room temperature. ${ }^{55}$ After thorough washing steps preparations were mounted and pictures were taken with an Olympus FV1000 confocal microscope at different random positions. Minimum of 5 pictures was taken from each group at each experiment. The images were analyzed for staining intensity using the FIJI (ImageJ) software.

\section{Simulations}

Model calculations were carried out on a flow channel by the COMSOL Multiphysics work package (Comsol Inc., USA) run on a personal computer, to describe time- and zeta potential dependence of the transient streaming potential signal. To optimize simulation time and disencumber processor capacity, a rectangular channel of proportionally reduced size and simplified geometry was used in the simulations. The average flow velocity at the inlet $\left(3.8 \times 10^{-4} \mathrm{~m} \mathrm{~s}^{-1}\right)$ was adjusted to the reduced size in order to be able to mimic the time course of the measured transient electric signal. The dimensions of the channel were $100 \mu \mathrm{m} \times 200 \mu \mathrm{m} \times 1200$ $\mu \mathrm{m}$. In the middle of this channel a $200 \mu \mathrm{m}$ by $300 \mu \mathrm{m}$ inner wall segment, representing the slipping plane, was carrying a surface charge density of $0.172 \mathrm{C} \mathrm{m}^{-2}$. The electrolyte comprised of a NaCl-water solution of $137 \mathrm{mM}$ concentration, with ambient pressure and temperature values, to mimic typical measuring conditions. For details of the simulation see ESI $\uparrow$ Fig. S1. The simulations were carried out by solving coupled differential equations of the electrostatics, transport of diluted species and creeping flow work packages (ESI $\dagger$ Fig. S1), using the Poisson approximation (1)-(3) and the Nernst-Planck (4), and Navier- 
Stokes equations for the creeping flow of an incompressible fluid (5)-(6), respectively:

$$
\begin{gathered}
\nabla \cdot \boldsymbol{D}=\rho_{\mathrm{V}} \\
-\boldsymbol{n} \cdot \boldsymbol{D}=\sigma_{\mathrm{S}} \\
\boldsymbol{E}=-\nabla V \\
\frac{\partial c_{j}}{\partial t}+\nabla \cdot\left(-D_{j} \nabla c_{j}-z_{j} u_{\mathrm{m}, j} F c_{j} \nabla V\right)+\boldsymbol{u} \cdot \nabla c_{j}=\mathbf{0} \\
0=\nabla \cdot\left[-p \boldsymbol{I}+\mu\left(\nabla \boldsymbol{u}+(\nabla \boldsymbol{u})^{T}\right)\right]+\boldsymbol{F} \\
\rho \nabla \cdot(\boldsymbol{u})=0
\end{gathered}
$$

Here $\boldsymbol{D}$ and $\boldsymbol{E}$ are the electric displacement and field strength, respectively, $\rho_{\mathrm{V}}$ and $\sigma_{\mathrm{S}}$ are volume and surface charge densities, $\boldsymbol{n}$ is the normal vector of the surface, $V$ is the electric potential, $c_{j}$ is the concentration of the $j$ th ion of $z_{j}$ valency and $u_{\mathrm{m}, j}$ mobility, $F$ is the Faraday constant, $\boldsymbol{u}$ is the flow velocity, $p$ is the pressure, $\boldsymbol{I}$ is the volumetric current flux, $\mu$ is the dynamic viscosity, $\boldsymbol{F}$ is the volumetric force, and $(\nabla \boldsymbol{u})^{T}$ is the shear stress term. The simulations were carried out in two steps: first, under no-flow conditions a stationary state was developed, while in the second step, a creeping flow was also introduced. The coupled differential equations were solved by the implicit method of backward differentiation formula (BDF).

\section{Statistics}

Data are presented as means \pm SD. Statistical significance between groups was determined by one-way ANOVA with Bonferroni multiple comparison tests, by unpaired $t$-test or by paired $t$-test (GraphPad Prism 5.0, GraphPad software, USA). The number of parallel samples were minimum 3 , and significance was considered at $p<0.05$. Experiments were repeated at least two times with multiple parallels.

\section{Results and discussion}

\section{Design and operation of the device}

The basic structure of the barrier device mimics that of the culture inserts: top and bottom channels separated by a porous PET membrane (Fig. 1A). The two parallel channels were made of PDMS. The geometry of the top and bottom channels are $36 \mathrm{~mm} \times 2 \mathrm{~mm} \times 1 \mathrm{~mm}$ and $42 \mathrm{~mm} \times 2 \mathrm{~mm} \times 2$ $\mathrm{mm}$, respectively, which $90 \%$ overlap providing higher sensitivity for in vitro permeability assays. It should be noted that the height of the top channels was reduced to half as compared to the device in our previous publication. ${ }^{37}$ Plastic slides with transparent gold TEER electrodes cover the two channels (Fig. 1A). The $25 \mathrm{~nm}$ thick gold electrodes were formed with a masking technique using sputter-coated gold deposition. ${ }^{37} \mathrm{~A}$ four-point probe configuration was designed for the precise impedance measurement, which electrically covered and enabled monitoring of the whole surface of the PET culture membrane $(36 \mathrm{~mm} \times 2 \mathrm{~mm})$. Copper wires were bound to the transparent gold electrodes using conductive epoxy, thus the EVOM voltohmmeter could be connected to the device (Fig. 1B).

The plastic tubes and the zeta electrodes were connected to the device via Luer lock inlets. The $\mathrm{Ag} / \mathrm{AgCl}$ zeta electrodes were inserted in Luer connectors, so they could be mounted easily (Fig. 1C). A programmable syringe pump fed the cells during the growth period (3 days) every 8 hours, while the TEER values were recorded and the monolayer was monitored with a phase contrast microscope, each day. Automatic feeding decreased the chances of contamination, too. The devices were connected in line ( 3 to 6 at one experiment), thus the flow rate and shear stress (0.4 dyn) were the exact same in all cultures. Before the cell monolayers reached full confluence, a peristaltic pump was introduced for constant flow, to mimic the shear stress of the bloodstream in veins for 1 day. The flow rate was $500 \mu \mathrm{l}$

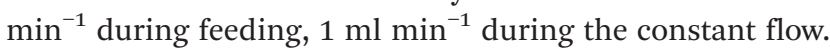

The streaming potential was measured with the $\mathrm{Ag} / \mathrm{AgCl}$ electrodes (Fig. 1C) between the inlet and outlet sides of the top channel (Fig. 2). For the recording, the flow was periodically stopped and restarted after equilibration of the ions close to the surface of the cell monolayer. Please note that contrary to the usual streaming potential measurements working with moderate flow rates, we do not operate our device under stationary conditions where the forward streaming current and the backward conductive current keep an equilibrium, but rather measure transient signals (Fig. 3A) by applying a strong input flow, in order to increase the signal-to-noise ratio. Although, this case is beyond the scope of the Helmholtz-Smoluchowski equation establishing a linear relationship between the zeta and steady-state streaming potentials, here we present experimental and theoretical evidence for the proportionality of the zeta potential and the amplitude of the transient streaming potential in our approach, as well.

\section{The streaming potential feature: experimental validation of the method}

In this work, the streaming potential was measured either on a test membrane or on cell monolayers, in the form of a transient potential difference evolving between the inlet and outlet electrodes, due to migration of ions from the vicinity of the negatively charged surface of the channel under flow conditions (Fig. 2A). The negative charge derives from the overwhelming anionic groups on the surface of the confluent cell monolayer due to the lipid headgroups ${ }^{2}$ and the surface glycocalyx in the BBB experiments, ${ }^{15}$ or from the sulfate groups of the Nafion membrane in the control measurements. The electric double layer close to a charged surface has a different ion concentration compared to the solution. If flow is applied to the system, the mobile part of the GCL containing an excess number of positive counterions 
move towards the outlet electrode, and temporarily increase the positive charge density in the larger volume of the socket of the electrode, giving rise to an increase in electric potential, as compared to the reference electrode (Fig. 3A). As we show by both model calculations (Fig. 3B) and control experiments using the LDv method, the amplitude of this transient streaming potential signal is proportional to the zeta potential of the membrane surface.

A highly negatively charged Teflon derivative, the sulfonated tetrafluoroethylene-based fluoropolymercopolymer called Nafion was selected to perform the proofof-concept experiments by the streaming potential electrodes incorporated in the chip. Since Nafion is available both in $183 \mu \mathrm{m}$ thick membrane sheets and in liquid suspension, it is suitable for both the transient streaming potential measurements and for LDv (Fig. 4A and B), where the latter can serve as a control for calibration.

For the streaming potential study, the PET membrane of the chip was replaced by a Nafion membrane, and the adjacent microfluidic channels were filled up by PBS, in order to mimic the ionic conditions of the incubating solution of endothelial cells, most frequently used in our earlier BBB chip experiments. ${ }^{37}$ Following the application of an inflow on the upper microfluidic channel of the device (Fig. 2A), a well-measurable transient electric potential change could be recorded under $1 \mathrm{ml} \mathrm{min}^{-1}$ flow rate, using a voltage preamplifier and an oscilloscope (Fig. 3A). The sign of the transient signal corresponded to a displacement of positive charges in the direction of the flow, indicating an overall negative zeta potential of the surface of the channel. After a 1 minute post-measurement incubation time without
A

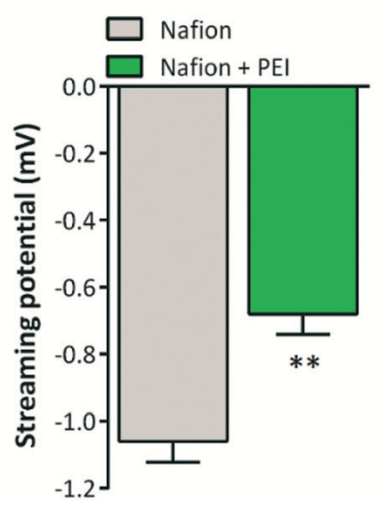

B

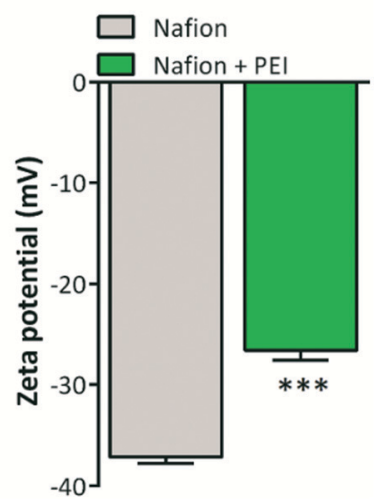

Fig. 4 Measurement of the surface charge of Nafion by streaming potential and by laser-Doppler velocimetry (LDv) methods. (A) Nafion film replaced the culture membrane in the biochip. It was treated with polyethylenimine and the streaming potential was measured before and after the treatment. Values are presented as means \pm SD, $n=4$. Data was analysed by unpaired $t$-test. **, $p<0.01$, compared to control. (B) Nafion beads were treated with PEI and the samples were measured with LDv before and after the treatment. Values are presented as means $\pm \mathrm{SD}, n=5$. Data was analysed by unpaired $t$-test. ***, $p<0.001$, compared to control groups. flow, the signal could be quantitatively reproduced. As a single-parameter descriptor of the transient signal, we chose its amplitude for comparison with the results of subsequent measurements. Note that here the convention of the sign was the opposite compared to the traditional streaming potential measurements, ${ }^{56}$ as the reference electrode was on the lowpressure end of the channel. Hence, the sign of the measured signal was the opposite of that of the zeta potential since the amplitude was proportional to the concentration of the counterions. According to the convention, the amplitude of the streaming potential of the untreated Nafion membrane was found to be $-1.06 \pm 0.0625 \mathrm{mV}$ (Fig. 4A).

To change the surface charge density, the Nafion membrane, was treated for 30 min with PEI, known to be able to attach via highly positively charged ethyleneimine residues to the surface. Its access quantity was subsequently washed away with PBS, and the streaming potential was measured again. The result showed a pronounced decrease of the absolute value of the amplitude to $-0.68 \pm 0.061 \mathrm{mV}$ (Fig. 4A). Control measurements without Nafion membrane showed negligible streaming potential signal, indicating that the zeta potential of the PDMS channel walls was insignificant, as compared to the highly negatively charged Nafion membranes. ${ }^{57}$

In order to calibrate the results gained by the transient streaming potential method with well-established techniques, LDv was applied to measure the zeta potential of Nafion beads prepared of identical material characteristics to those of the membrane. The Nafion stock solution $(\mathrm{pH}=1.5)$ had a $-76.2 \pm 2.08 \mathrm{mV}$ zeta potential measured with Malvern Zetasizer Nano ZS. Then the stock was centrifuged and resuspended in PBS $(\mathrm{pH}=7.2)$, therefore the Nafion beads had the same ionic conditions as in the streaming potential experiments, and had a zeta potential of $-37.13 \pm 0.63 \mathrm{mV}$. Another batch of beads was then treated with PEI, and subsequently re-centrifuged and resuspended in PBS. The PEI-treated beads showed a similar ratio of increase in zeta potential up to $-26.58 \pm 0.94 \mathrm{mV}$ (Fig. 4B), as it was observed for the streaming potentials of analogously treated Nafion membranes (Fig. 4A).

Based on the fact that the ratios of the zeta and streaming potentials of the native and PEI-treated Nafion surfaces were the same within the experimental error, a proportionality between the data measured by the two different methods were suggested. Below, we present both theoretical and further experimental evidence supporting this finding.

\section{The streaming potential feature: simulations}

In order to give a theoretical background for the measured transient streaming potential signals, we carried out model calculations on a flow channel by the COMSOL Multiphysics work package. The dynamics of the system was modelled in two steps: 1) to establish stationary conditions without flow, first the system was let to equilibrate according to the Poisson-Boltzmann-Nernst-Planck approximation, assuming 
electro-neutrality of the channel-fluid system; 2) in the second step, a creeping flow with an average velocity of $3.8 \times$ $10^{-4} \mathrm{~m} \mathrm{~s}^{-1}$ was applied (ESI $\dagger$ Fig. S2)to the inlet of the channel, and the electric potential was measured on two probe planes placed in front of and behind the charged surface, along the long axis of the channel. A typical voltage signal received by subtracting the two potentials is shown in Fig. 3B, faithfully reflecting the time-evolution of the measured signal (Fig. 3A). In order to establish the connection between the simulated signal amplitudes and the zeta potential, the latter was swept two orders of magnitude, and the simulated time-evolution of the streaming potential functions was recorded (ESI $\dagger$ Fig. S3, Video V2). Fig. 5B shows the dependence of the amplitudes of these curves as a function of the zeta potential, showing a clear linear relationship, in full concert with the experiments (see the previous section, and Fig. 5A).

The above experimental and model calculation results proved that the concept of upgrading our chip device by a streaming potential unit, to detect the zeta potential of the membrane insert and monitor its changes, is feasible. Nevertheless, it remained an important question whether the method is appropriate (i.e. sensitive enough) to characterize changes in the surface charge properties of cellular monolayers, such as those in biological barriers. In the forthcoming sections, we address this problem via the experimental investigation of an in vitro BBB model system.

\section{Effects of surface charge modifications and measurement of streaming potential on a cell culture model of the BBB}

There is an increasing number of direct and indirect evidence that simple physical parameters such as surface charge density or the related zeta potential might control physiological functions of barrier properties. ${ }^{2,17}$ The main sources of the, usually negative, surface charge densities of cells are the lipid head groups of the plasma membrane, and the so-called glycocalyx, composed of highly negatively charged polysaccharide chains at the surface of the cells (Fig. 6A). Glycocalyx forms a continuous coat on the luminal surface and plays important roles as both a mechanosensor ${ }^{55}$ and as a physical barrier for nanoparticle permeability. ${ }^{16}$ The negative surface charge derived from the lipid head groups of the $\mathrm{BBB}$ regulates both drug delivery to the brain ${ }^{14}$ and drug interaction at the level of brain endothelial cells. ${ }^{17}$ Therefore, the surface charge density of brain endothelial cells can be modified by both enzymatic digestions of the glycocalyx or cationic lipophilic molecules that are inserted into the plasma membrane (Fig. 6A). To determine changes in the surface charge of individual cells $\mathrm{LDv}$ measurements are used. ${ }^{2,17}$

In our study, we measured the streaming potential on confluent monolayers of barrier cells cultured in a LOC device for the first time. We used two clinically relevant surface charge modulators (Fig. 6A). The antiarrhythmic intravenous drug, lidocaine incorporates into the plasma membrane of vascular endothelial cells and as we demonstrated in a recent study it changes the zeta potential of brain endothelial cells. ${ }^{17}$ Neuraminidase, a glycosidehydrolase enzyme, cleaves sialic acids and reduces the amount of negative charge on the glycocalyx, thus mimics glycocalyx shedding observed in sepsis. ${ }^{6}$ Cleavage of glycocalyx elements turns cellular surface charge more positive, although this change has not been measured directly on brain endothelial cells yet. The efficiency of cleavage of sialic acid residues from the glycocalyx by neuraminidase was determined by the sialic acid-specific lectin WGA-Alexa 488 staining, followed by confocal microscopy and image analysis for staining intensity (Fig. 6B and C). A concentration-dependent effect of the

\section{A}

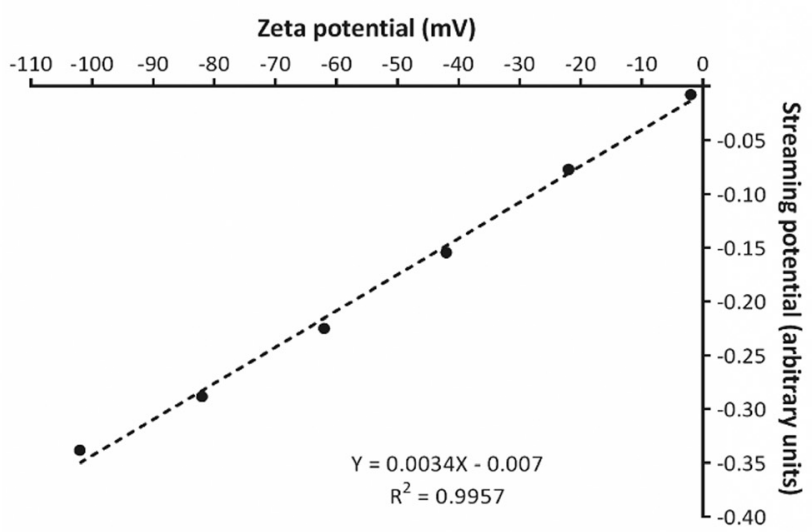

B

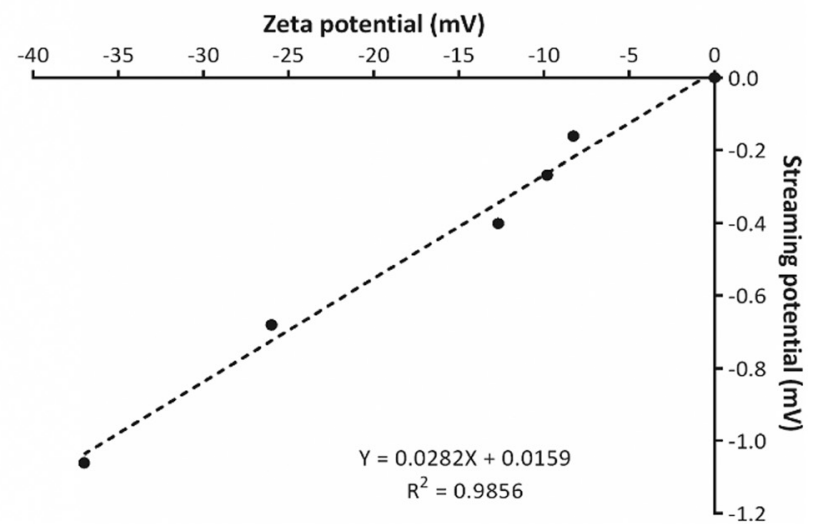

Fig. 5 Correlation between streaming potential and laser-Doppler velocimetry. (A) Correlation of the simulation. The zeta potential was set in the channel as a charged section of the wall and the corresponding streaming potential was calculated by the simulation. (B) The streaming potential and laser-Doppler velocimetry data measured on Nafion or the confluent brain endothelial cell layers were plotted and fitted with linear regression. The two goodness-of-fits are $R^{2}=0.996$ and $R^{2}=0.986$ respectively, which shows a clear linear relationship between the zeta and streaming potential. 
A

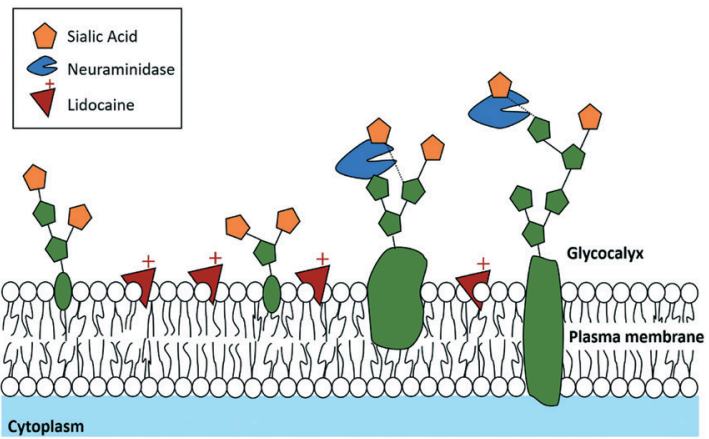

cytoplasm
B

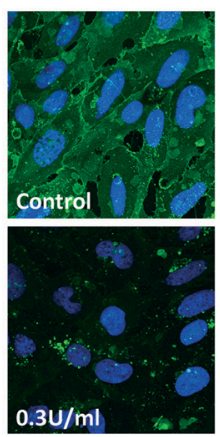

E

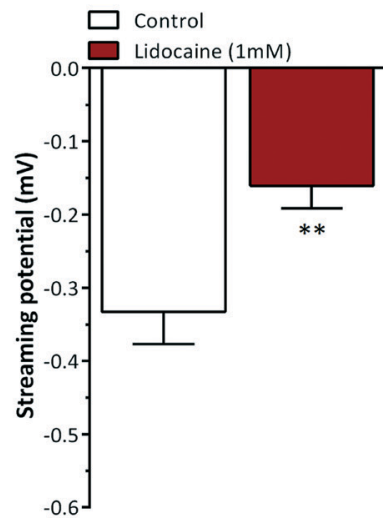

C
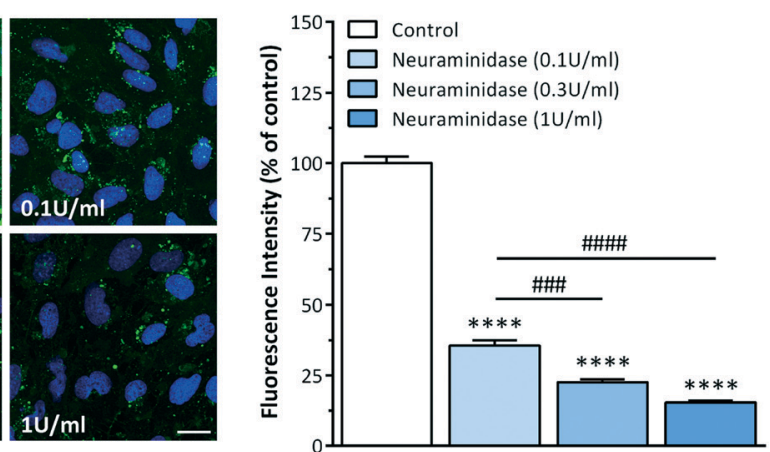

F

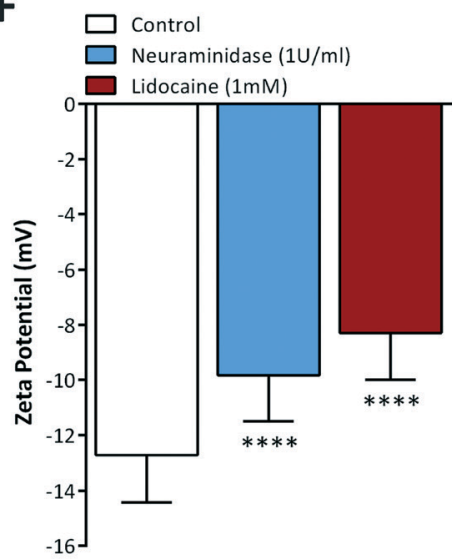

Fig. 6 Measurement of surface charge and its modification on brain endothelial cells by streaming potential in the chip device and by laserDoppler velocimetry (LDv). (A) The two strategies to modify the zeta potential were the cleavage of the glycocalyx or the insertion of positively charged molecules in the membrane. Neuraminidase enzyme cleaves the sialic acids of the polysaccharide sidechains, thus decreases the amount of negative charges on the cell surface. Lidocaine incorporates into the cell membrane and makes it more positive. (B) Representative pictures of the staining with wheat germ agglutinin (WGA) lectin labeled with Alexa 488 with or without treatments with different concentrations of neuraminidase, bar: $20 \mu \mathrm{m}$. (C) Image analysis of the fluorescent intensity of the lectin labeling on pictures taken by confocal microscopy. Values are presented as means $\pm \mathrm{SD}, n=30-66$. Data was analysed by one-way ANOVA with Bonferroni post-test. $* * * *, \# \# \# p<0.0001, \# \# \# p<$ 0.001. ( $D$ and $E$ ) Streaming potential values measured in the chip device. Values are presented as means $\pm S D, n=4$. Data was analysed by unpaired $t$-test. **, $p<0.01$, compared to control. (F) Zeta potential results obtained with LDv method. Values are presented as means \pm SD, $n=$ 12-60. Data was analysed by one-way ANOVA with Bonferroni post-test. ****, $p<0.0001$, compared to control.

enzyme on lectin staining was obtained: neuraminidase treatment at $1 \mathrm{U} \mathrm{ml}^{-1}$ concentration reduced the labeling by $80 \%$ on the surface of BEC after $1 \mathrm{~h}$ treatment, while lower concentrations were less effective (Fig. 6B and C).

The effects of the two different treatments were tested by measuring transient streaming potential signals on the chip (Fig. 6D and E). To this end, a fluid flow of $1 \mathrm{ml} \mathrm{min}^{-1}$ was applied on the upper channel of the device, containing the brain endothelial cell monolayer and the flow of charges was registered. As shown in Fig. 6D and E, both treatments increased the streaming potential of the cell monolayers. Neuraminidase treatment was performed at a concentration of $1 \mathrm{U} \mathrm{ml}^{-1}$, since it was the most effective concentration in reducing sialic acids from the glycocalyx (Fig. 6B and C). Addition of neuraminidase increased the streaming potential of cell layers to $-0.268 \pm 0.086 \mathrm{mV}$ from $-0.470 \pm 0.047 \mathrm{mV}$ (Fig. 6D). Lidocaine, the other surface charge modulator in our experiments, is widely used as an anaesthetic or antiarrhythmic drug. We demonstrated in our previous study by LDv that it modifies the zeta potential of BEC. ${ }^{17}$ Since we found no toxic effect of lidocaine at $1 \mathrm{mM}$ concentration, ${ }^{17}$ this concentration was used on the BEC monolayers cultured in the LOC device. In Fig. $6 \mathrm{E}$, the streaming potential is shown to increase from $-0.333 \pm 0.089 \mathrm{mV}$ to $-0.161 \pm 0.061$ $\mathrm{mV}$ upon lidocaine treatment. For comparison with the results obtained by the streaming potential measurements, single-cell experiments were performed using the same treatments but the LDv method. As shown in Fig. 6F, neuraminidase treatment significantly increased the surface charge of BEC to $-9.83 \pm 1.67 \mathrm{mV}$, while lidocaine elevated it to $-8.29 \pm 1.71 \mathrm{mV}$ from the $-12.7 \pm 1.71 \mathrm{mV}$ measured in basal conditions when no treatment was applied. The lower, $0.1 \mathrm{U} \mathrm{ml}^{-1}$ and $0.3 \mathrm{U} \mathrm{ml}^{-1}$ concentrations of neuraminidase resulted in smaller changes in the zeta potential of BEC (ESI $\dagger$ Fig. S4), in accordance with the glycocalyx staining results (Fig. 6B and C).

After completing the experiments on both Nafion and cells, the streaming potential amplitudes recorded on the 
LOC device and the zeta potential values measured by the LDv technique were compared to seek possible correlation. Fig. 5B shows the streaming potential results plotted as a function of zeta potential, including the Nafion results. The graph was fitted with linear regression, and the result showed a clear linear relationship between the data gathered by the two methods, with a goodness-of-fit of $R^{2}=0.988$.

The results clearly prove the feasibility of the new "zetafeature" of the device, at the same time provide a calibration factor for the determination of the zeta potential of the cell layer. It was also shown that the sensitivity of the technique is sufficient to measure changes in the surface charge properties of the BBB layer that was demonstrated to be linked to altered penetration of charged molecules and nanoparticles. ${ }^{2,16,17}$ The question arises, however, whether the changes in surface charge measured by streaming or zeta potential were accompanied by alterations in barrier parameters, such as permeability for ions (TEER) or neutral hydrophilic molecules.

\section{Barrier integrity of cell monolayers in the LOC device}

To investigate if zeta potential changes are linked to changes in passive paracellular permeability or are independent indicators of function further experiments were performed. The tightness of the paracellular pathway, restricted by tight intercellular junctions, can be tested with hydrophilic molecules. ${ }^{9,25,58,59}$ Electrical impedance measurement at low frequency (called as TEER) is the most sensitive method to characterize the paracellular barrier integrity for ions. ${ }^{25,60}$ The TEER (measured at $12.5 \mathrm{~Hz}$ ) of the BBB model was determined both in the device (Fig. 7) and in culture inserts (ESI $\dagger$ Fig. S5). The resistance of the BEC cultures in the LOC device did not change after treatments (Fig. 7A) and the same result was shown on culture inserts for neuraminidase (ESI $\uparrow$ Fig. S5A). Since the paracellular permeability for both ions and neutral hydrophilic molecules is regulated by the tight intercellular junctions, changes in the cell surface zeta potential are not expected to affect this pathway. The removal of the sialic acid residues from the glycocalyx or the insertion of a positively charged molecule in the plasma membrane of the cells did not result in any statistical difference in the paracellular permeability for dextran as compared to the control group, as it was expected for a neutral large tracer molecule. The same was observed on culture inserts as shown in ESI $\dagger$ Fig. S5B. These data are in agreement with our previous results describing that treatment of $\mathrm{BBB}$ culture models with lidocaine did not change the permeability of neutral hydrophilic markers such as dextran. ${ }^{17}$ In concordance with TEER and permeability data the cell morphology of BEC was unchanged as the same immunostaining pattern was observed for the junctional linker protein $\beta$-catenin after treatments as compared to the control cells (Fig. 7C). Similar BEC morphology was also observed after neuraminidase treatment by phase contrast microscopy (ESI $\dagger$ Fig. S5C). These control experiments prove that modulation of endothelial cellular surface charge with neuraminidase or lidocaine did not affect barrier integrity of
A

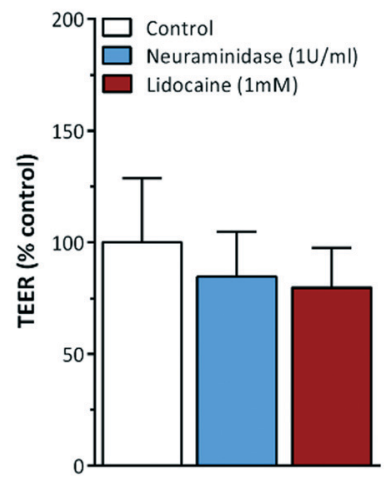

B

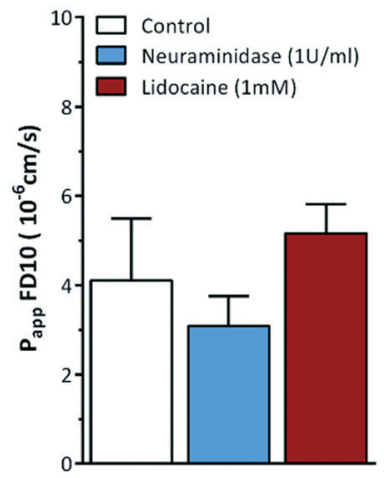

C

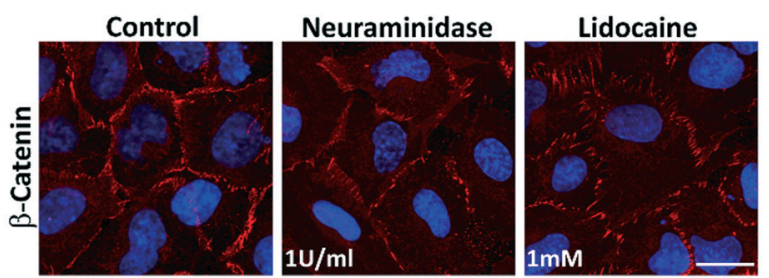

Fig. 7 The effects of the treatments modifying the surface charge of confluent brain endothelial cells on the paracellular barrier properties measured in the chip device. (A) Transendothelial electric resistance (TEER) results were normalized to the values of the control group which received culture medium instead of treatments for the same period. (B) Apparent permeability coefficient $\left(P_{\text {app }}\right)$ of the brain endothelial monolayers for the neutrally charged fluorescently labeled $10 \mathrm{kDa}$ dextran (FD10), a marker of paracellular permeability. (C) Cell morphology was characterized by immunostaining for $\beta$-catenin, a linker protein of adherens junctions, and visualised by confocal microscopy. Bar: $20 \mu \mathrm{m}$.

the cell layers and that both TEER and zeta potential, two independent essential parameters can be measured with the device.

\section{Conclusions and outlook}

We successfully measured the streaming potential of a biological barrier culture model with the help of our versatile lab-on-a-chip device upgraded with two $\mathrm{Ag} / \mathrm{AgCl}$ electrodes. The inclusion of the "zeta electrodes", a voltage preamplifier and an oscilloscope in our set-up made it possible to successfully record signals describing the surface charge properties of brain endothelial cell monolayers, used as a barrier model in our experiments. The new technique was verified by comparing streaming potential data obtained in the LOC device and zeta potential results by the commonly used LDv method. Changes in the negative surface charge of the barrier model by treatments with neuraminidase enzyme modifying the plasma membrane glycocalyx or lidocaine altering the lipid membrane charge could be measured by both the novel LOC device and LDv. The device as we proved earlier can be used for different types of biological barriers, 
such as respiratory and intestinal epithelial cell cultures and co-culture models of the BBB. ${ }^{37}$ Potential application of the new LOC zeta device can be two-fold. Surface charge and its changes can be measured by registering the streaming potential on other epithelial and endothelial barrier systems including lung, intestine, kidney and cornea. On the other hand, changes in either the glycocalyx of the vascular or other barriers caused by pathologies such as diabetes, sepsis, hypertension or virus infection or changes in the plasma membrane caused by charged molecules or drugs can be modeled and directly measured on intact cell layers. Our technique is, in principle, compatible with further miniaturization of the channel to adapt the system for screening purposes. The new device can help to gain meaningful novel information on how surface charge is linked to barrier function in both physiological and pathological conditions.

\section{Author contribution}

Conceptualization, A. K., A. R. S. M., M. A. D., A. D.; methodology, A. K., A. R. S. M., S. V., M. A .D. and A. D.; formal analysis, A. K., A. R. S. M., F. R. W., S. V., L. D., A. D.; investigation, A. K., A. R. S. M., F. R. W., N. H., D. V. L., A. D..; resources, A. K., A. R. S. M., L. D., S. V., A. D., data curation, A. K., A. R. S. M., F. R. W., S. V., L. D., A. D.; writing - original draft preparation, A. K., A. R. S. M., F. R. W., M. A. D., A. D.; writing - review and editing, A. K., A. R. S. M., F. R. W., L. D., S. V., M. A. D., A. D.; visualization, A. K., A. R. S. M., S. V., L. D.; project administration, F. R. W., M. A. D. and A. D.; supervision, M. A. D. and A. D., funding acquisition, M. A. D. and A.D.

\section{Conflicts of interest}

There is no conflict of interest to declare.

\section{Acknowledgements}

This work was supported by National Research, Development and Innovation Office, Hungary [grant numbers GINOP-2.3.215-2016-00001, GINOP-2.3.2-15-2016-00037, OTKA K-108697, NNE 129617 as part of the M-Era.NET2 nanoPD project]. A. R. S.-M. was supported by the European Training Network H2020-MSCA-ITN-2015 [grant number 675619]. FRW is currently supported by the National Research, Development and Innovation Office, Hungary [grant number OTKA PD128480], by the János Bolyai Research Fellowship of the Hungarian Academy of Sciences, and by the New National Excellence Program Bolyai+ fellowship (UNKP-19-4-SZTE-42) of the Ministry for Innovation and Technology, Hungary.

\section{References}

1 T. Yeung, G. E. Gilbert, J. Shi, J. Silvius, A. Kapus and S. Grinstein, Science, 2008, 319, 210-213.
2 M. M. Ribeiro, M. M. Domingues, J. M. Freire, N. C. Santos and M. A. Castanho, Front. Cell. Neurosci., 2012, 6, 44.

3 L. Möckl, Front. Cell Dev. Biol., 2020, 8, 253.

4 M. A. Deli, Biochim. Biophys. Acta, 2009, 1788, 892-910.

5 B. M. van den Berg, M. Nieuwdorp, E. S. Stroes and H. Vink, Pharmacol. Rep., 2006, 58, 75-80.

6 S. Dogné and B. Flamion, Am. J. Pathol., 2020, 190, 768-780.

7 F. Krammer, G. J. D. Smith, R. A. M. Fouchier, M. Peiris, K. Kedzierska, P. C. Doherty, P. Palese, M. L. Shaw, J. Treanor, R. G. Webster and A. García-Sastre, Nat. Rev. Dis. Primers, 2018, 4, 3.

8 N. J. Abbott, A. A. Patabendige, D. E. Dolman, S. R. Yusof and D. J. Begley, Neurobiol. Dis., 2010, 37, 13-25.

9 M. A. Deli, Solubility, Delivery and ADME Problems of Drugs and Drug-Candidates, ed. K. Tihanyi and M. Vastag, Bentham Science Ltd., Wasington DC, 2011, vol. 8, pp. 145-165.

10 P. Campos-Bedolla, F. R. Walter, S. Veszelka and M. A. Deli, Arch. Med. Res., 2014, 45, 610-638.

11 Y. Ando, H. Okada, G. Takemura, K. Suzuki, C. Takada, H. Tomita, R. Zaikokuji, Y. Hotta, N. Miyazaki, H. Yano, I. Muraki, A. Kuroda, H. Fukuda, Y. Kawasaki, H. Okamoto, T. Kawaguchi, T. Watanabe, T. Doi, T. Yoshida, H. Ushikoshi, S. Yoshida and S. Ogura, Sci. Rep., 2018, 8, 17523.

12 F. Hervé, N. Ghinea and J. M. Scherrmann, AAPS J., 2008, 10, 455-472.

13 B. M. Fu and J. M. Tarbell, Wiley Interdiscip. Rev.: Syst. Biol. Med., 2013, 5, 381-390.

14 M. M. Ribeiro, A. R. Pinto, M. M. Domingues, I. Serrano, M. Heras, E. R. Bardaji, I. Tavares and M. A. Castanho, Mol. Pharmaceutics, 2011, 8, 1929-1940.

15 G. Li and B. M. Fu, J. Biomech. Eng., 2011, 133, 021002-1-12.

16 M. Mészáros, G. Porkoláb, L. Kiss, A. M. Pilbat, Z. Kóta, Z. Kupihár, A. Kéri, G. Galbács, L. Siklós, A. Tóth, L. Fülöp, M. Csete, Á. Sipos, P. Hülper, P. Sipos, T. Páli, G. Rákhely, P. Szabó-Révész, M. A. Deli and S. Veszelka, Eur. J. Pharm. Sci., 2018, 123, 228-240.

17 A. R. Santa-Maria, F. R. Walter, S. Valkai, A. R. Brás, M. Mészáros, A. Kincses, A. Klepe, D. Gaspar, M. A. Castanho, L. Zimányi, A. Dér and M. A. Deli, Biochim. Biophys. Acta, Biomembr., 2019, 1861, 1579-1591.

18 R. J. Hunter, Zeta Potential in Colloid Science, Academic Press, San Diego, 1981.

19 E. Malher, D. Martin, C. Duvivier, B. Volochine and J. F. Stoltz, Biorheology, 1982, 19, 647-654.

20 I. B. Oldham, F. J. Young and J. F. Osterle, J. Colloid Sci., 1963, 18, 328-336.

21 R. A. Van Wagenen and J. D. Andrade, J. Colloid Interface Sci., 1980, 76, 305-314.

22 P. N. Sawyer, E. Himmelfarb, I. Lustrin and H. Ziskind, Biophys. J., 1966, 6, 641-651.

23 D. H. Smyth and E. M. Wright, J. Physiol., 1966, 182, 591-602.

24 R. B. Gandhi and J. R. Robinson, Pharm. Res., 1991, 8, 1199-1202.

25 M. A. Deli, C. S. Ábrahám, Y. Kataoka and M. Niwa, Cell. Mol. Neurobiol., 2005, 25, 59-127. 
26 H. C. Helms, N. J. Abbott, M. Burek, R. Cecchelli, P. O. Couraud, M. A. Deli, C. Förster, H. J. Galla, I. A. Romero, E. V. Shusta, M. J. Stebbins, E. Vandenhaute, B. Weksler and B. Brodin, J. Cereb. Blood Flow Metab., 2016, 36, 862-890.

27 S. Veszelka, A. Tóth, F. R. Walter, A. E. Tóth, I. Gróf, M. Mészáros, A. Bocsik, É. Hellinger, M. Vastag, G. Rákhely and M. A. Deli, Front. Mol. Neurosci., 2018, 11, 166.

28 C. M. Sakolish, M. B. Esch, J. J. Hickman, M. L. Shuler and G. J. Mahler, EBioMedicine, 2016, 5, 30-39.

29 M. W. van der Helm, A. D. van der Meer, J. C. T. Eijkel, A. van den Berg and L. I. Segerink, Tissue Barriers, 2016, 4, e1142493.

30 S. R. A. Kratz, G. Höll, P. Schuller, P. Ertl and M. Rothbauer, Biosensors, 2019, 9, 110.

31 I. Raimondi, L. Izzo, M. Tunesi, M. Comar, D. Albani and C. Giordano, Front. Bioeng. Biotechnol., 2020, 7, 435.

32 W. Neuhaus, R. Lauer, S. Oelzant, U. P. Fringeli, G. F. Ecker and C. R. Noe, J. Biotechnol., 2006, 125, 127-141.

33 R. Booth and H. Kim, Lab Chip, 2012, 12, 1784-1792.

34 B. Prabhakarpandian, M. C. Shen, J. B. Nichols, I. R. Mills, M. Sidoryk-Wegrzynowicz, M. Aschner and K. Pant, Lab Chip, 2013, 13, 1093-1101.

35 L. Cucullo, M. Hossain, W. Tierney and D. Janigro, BMC Neurosci., 2013, 14, 18.

36 Q. Ramadan, H. Jafarpoorchekab, C. Huang, P. Silacci, S. Carrara, G. Koklü, J. Ghaye, J. Ramsden, C. Ruffert, G. Vergeres and M. A. M. Gijs, Lab Chip, 2013, 13, 196-203.

37 F. R. Walter, S. Valkai, A. Kincses, A. Petneházi, T. Czeller, S. Veszelka, P. Ormos, M. A. Deli and A. Dér, Sens. Actuators, B, 2016, 222, 1209-1219.

38 Y. I. Wang, C. Carmona, J. J. Hickman and M. L. Shuler, Adv. Healthcare Mater., 2018, 7, 1-29.

39 B. M. Maoz, A. Herland, E. A. FitzGerald, T. Grevesse, C. Vidoudez, A. R. Pacheco, S. P. Sheehy, T. E. Park, S. Dauth, R. Mannix, N. Budnik, K. Shores, A. Cho, J. C. Nawroth, D. Segrè, B. Budnik, D. E. Ingber and K. K. Parker, Nat. Biotechnol., 2018, 36, 865-874.

40 T. E. Park, N. Mustafaoglu, A. Herland, R. Hasselkus, R. Mannix, E. A. FitzGerald, R. Prantil-Baun, A. Watters, O. Henry, M. Benz, H. Sanchez, H. J. McCrea, L. C. Goumnerova, H. W. Song, S. P. Palecek, E. Shusta and D. E. Ingber, Nat. Commun., 2019, 10, 2621.

41 C. M. Lo, C. R. Keese and I. Giaever, Exp. Cell Res., 1993, 204, 102-109.
42 B. Srinivasan, A. R. Kolli, M. B. Esch, H. E. Abaci, M. L. Shuler and J. J. Hickman, J. Lab. Autom., 2015, 20, 107-126.

43 N. Orgovan, B. Kovacs, E. Farkas, B. Szabó, N. Zaytseva, Y. Fang and R. Horvath, Appl. Phys. Lett., 2014, 104, 083506.

44 E. Farkas, A. Szekacs, B. Kovacs, M. Olah, R. Horvath and I. Szekacs, J. Hazard. Mater., 2018, 351, 80-89.

45 R. M. Fike and C. J. van Oss, In Vitro, 1976, 12, 428-436.

46 R. A. Van Wagenen, J. D. Andrade and J. B. Hibbs Jr, J. Electrochem. Soc., 1976, 123, 1438-1444.

47 P. Vandrangi, P. Jreij, T. E. Rajapaksa, N. Bansal, D. D. Lo and V. G. J. Rodgers, Rev. Sci. Instrum., 2012, 83, 074302.

48 P. Vandrangi, D. D. Lo, R. Kozaka, N. Ozaki, N. Carvajal and V. G. J. Rodgers, Biotechnol. Bioeng., 2013, 110, 2742-2748.

49 B. B. Weksler, E. A. Subileau, N. Perrière, P. Charneau, K. Holloway, M. Leveque, H. Tricoire-Leignel, A. Nicotra, S. Bourdoulous, P. Turowski, D. K. Male, F. Roux, J. Greenwood, I. A. Romero and P. O. Couraud, FASEB J., 2005, 19, 1872-1874.

50 A. Singh, S. C. Satchell, C. R. Neal, E. A. McKenzie, J. E. Tooke and P. W. Mathieson, J. Am. Soc. Nephrol., 2007, 18, 2885-2893.

51 D. Gross and W. S. Williams, J. Biomech., 1982, 15, 277-295.

52 Z. A. Kostiuchenko, J. Z. Cui and S. G. Lemay, J. Phys. Chem. C Nanomater Interfaces, 2020, 124, 2656-2663.

53 K. A. Mauritz and R. B. Moore, Chem. Rev., 2004, 104, 4535-4585.

54 E. Hellinger, S. Veszelka, A. E. Tóth, F. R. Walter, A. Kittel, M. L. Bakk, K. Tihanyi, V. Háda, S. Nakagawa, T. D. Duy, M. Niwa, M. A. Deli and M. Vastag, Eur. J. Pharm. Biopharm., 2012, 82, 340-351.

55 K. B. Betteridge, K. P. Arkill, C. R. Neal, S. J. Harper, R. R. Foster, S. C. Satchell, D. O. Bates and A. H. J. Salmon, J. Physiol., 2017, 595, 5015-5035.

56 F. D. Morgan, E. R. Williams and T. R. Madden, J. Geophys. Res., [Solid Earth Planets], 1989, 94, 12449-12461.

57 R. Peng and D. Li, Nanoscale, 2016, 8, 12237-12246.

58 N. J. Abbott, L. Rönnbäck and E. Hansson, Nat. Rev. Neurosci., 2006, 7, 41-53.

59 M. Cereijido, R. G. Contreras, L. Shoshani, D. Flores-Benitez and I. Larre, Biochim. Biophys. Acta, 2008, 1778, 770-793.

60 K. Benson, S. Cramer and H. J. Galla, Fluids Barriers CNS, 2013, 10, 5 . 
Electronic Supplementary Material (ESI) for Lab on a Chip.

This journal is @ The Royal Society of Chemistry 2020

\section{Electronic Supplementary Information}

A chip device to determine surface charge properties of confluent cell monolayers by measuring streaming potential

András Kincses ${ }^{a, b}$, Ana R. Santa-Maria ${ }^{a, c}$, Fruzsina R. Walter ${ }^{a, d}$, László Déra, Nóra Horányia , Dóra

V. Lipkaa , Sándor Valkai ${ }^{a}$, Mária A. Delia,*, András Déra,*

a Institute of Biophysics, Biological Research Centre, Szeged, Hungary

${ }^{b}$ Doctoral School of Multidisciplinary Medical Sciences, University of Szeged, Hungary

${ }^{\mathrm{c}}$ Doctoral School of Biology, University of Szeged, Hungary

${ }^{d}$ Department of Cell Biology and Molecular Medicine, University of Szeged, Hungary

*Corresponding authors: der.andras@brc.hu, deli.maria@brc.hu 


\section{Section I. Simulation}

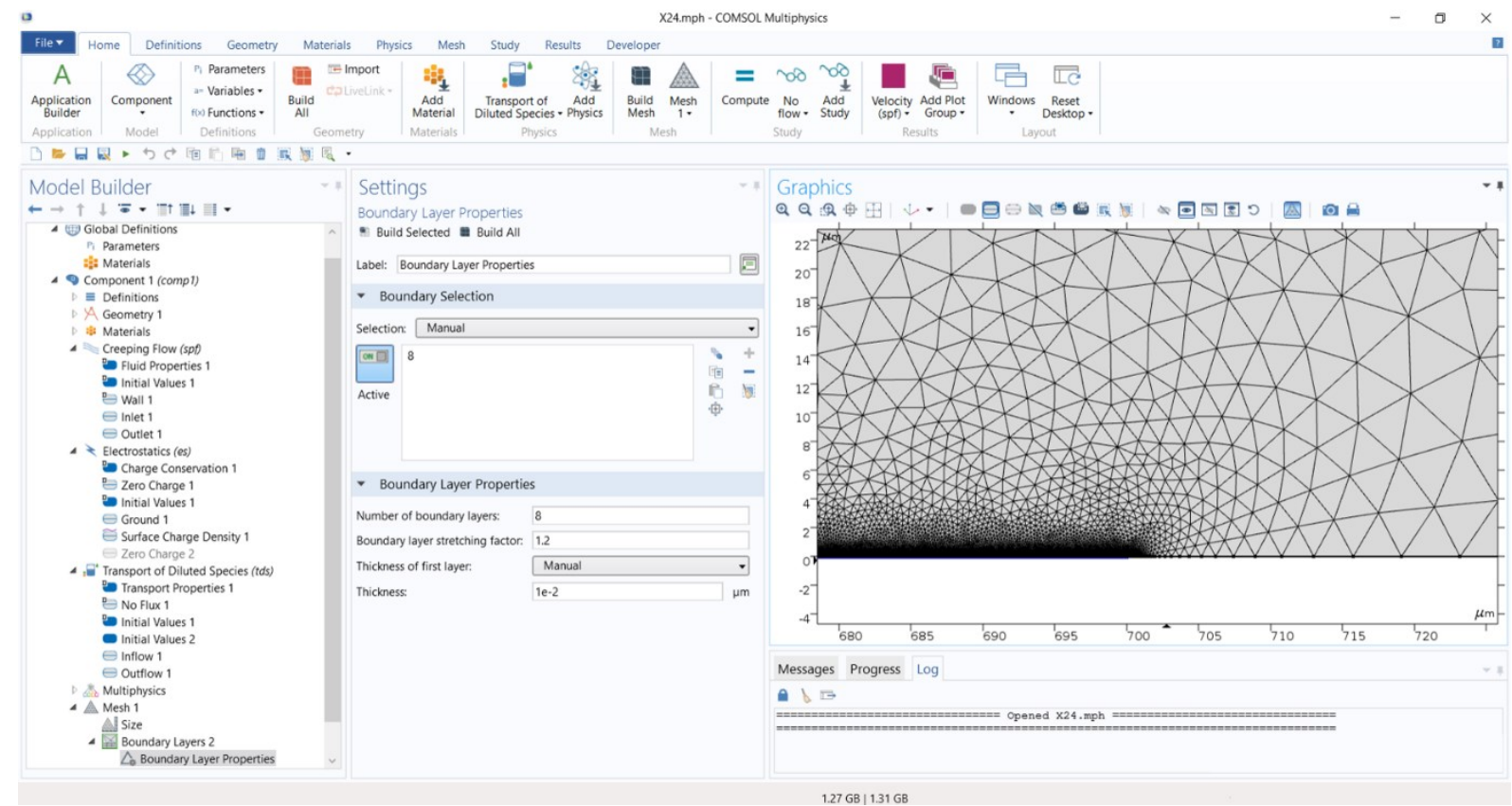

ESI Figure S1 Three of the Multiphysics platforms of COMSOL were used for the simulations: Creeping Flow (spf), Electrostatics (es) and Transport of Diluted Species (tds). Between them, the following coupling modes were introduced: Potential Coupling (pc1), Space Charge Density Coupling (sdc1) and Flow Coupling (fc1). The simulation was performed in a 2D (a semi-3D) environment. The geometry of the model system (the channel) was a straight pipe with parallel walls. At the bottom of the channel, a partial section was the charged surface with a known zeta-potential (the highest density of mesh points). There is a trade-off between the number of mesh-points (that still can be handled by the computer) and the resolution of the mesh that influences heavily the convergence of the iterations.

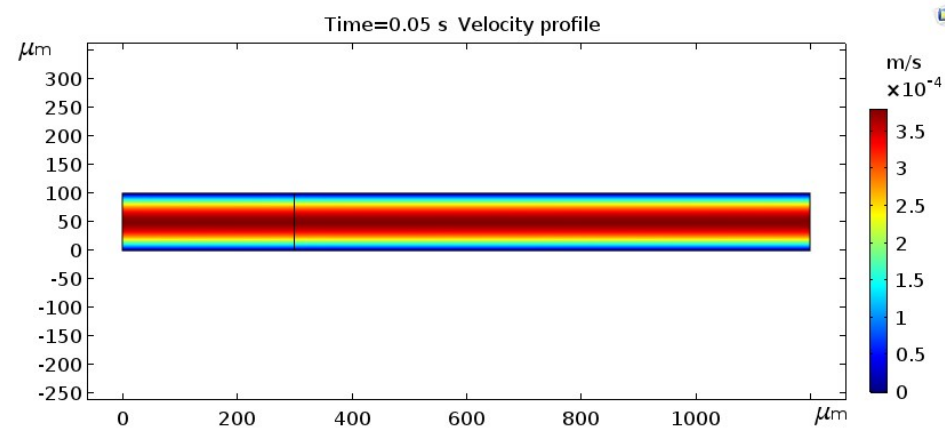

ESI Figure S2 Velocity profile in the longitudinal section of the channel under laminar flow conditions. A laminar inflow condition was set at the inlet in the Creeping Flow module, too, so the steady state was developed during the very first time steps. The vertical line at $300 \mu \mathrm{m}$ shows the position of the reference electrode, while the measuring electrode was positioned at the outlet surface (right end of the channel).

To model the dependence of the streaming potential on zeta potential, a parametric sweep of the zeta potential at the charged surface section was applied.

A movie demonstrating changes of the cation concentration profile in the longitudinal section of the channel, and simultaneously showing the simulated electric potential at the outlet is presented in ESI Video V2. Snapshots of this movie at selected time points are depicted in ESI Figure S3. 

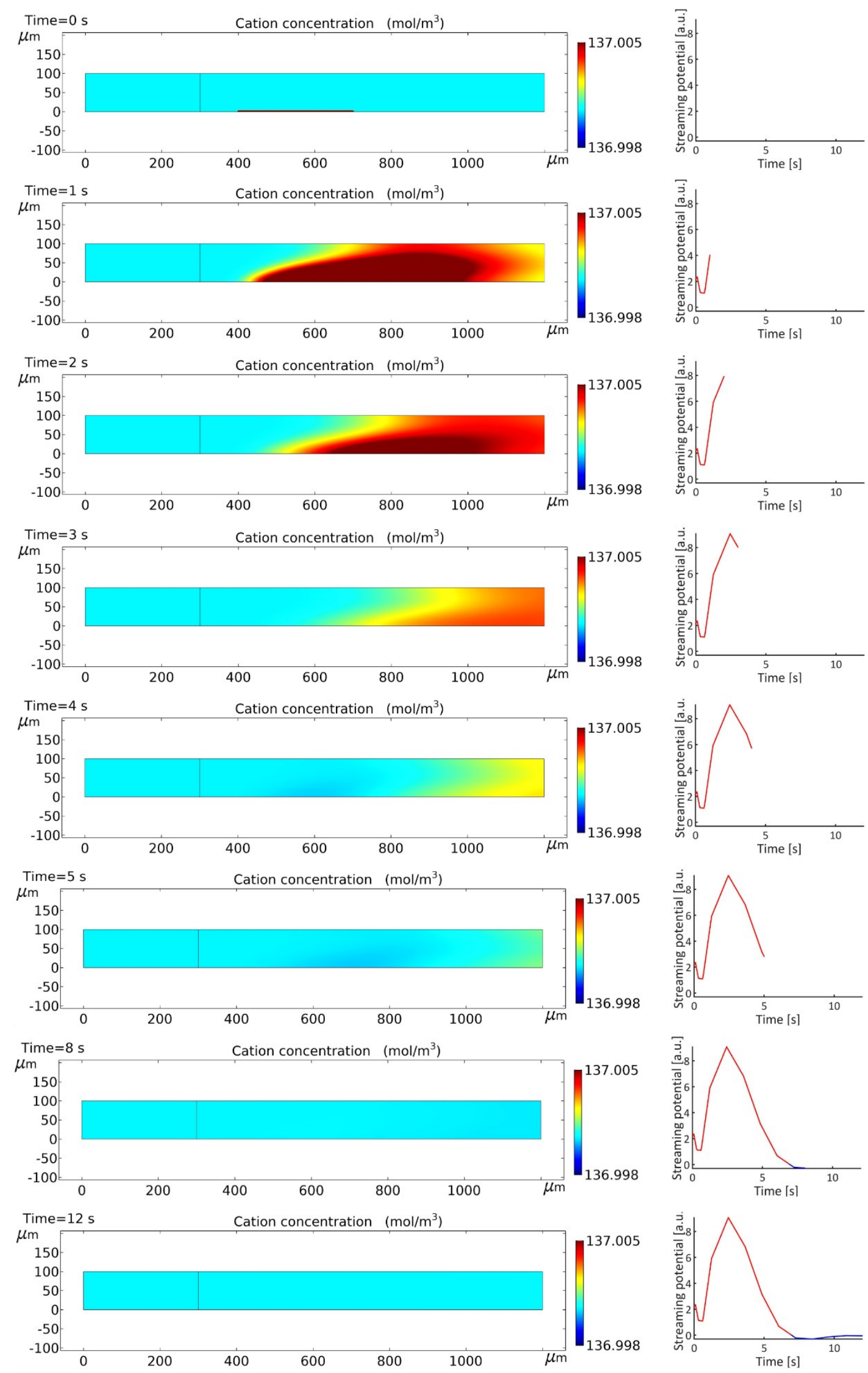

ESI Figure S3 Simulated movement of the counterion cloud under creeping flow, and the time evolution of potential difference between the measuring and reference electrodes. Note that the vertical line at $300 \mu \mathrm{m}$ represents the reference electrode. 

treatments at lower concentrations and barrier measurements

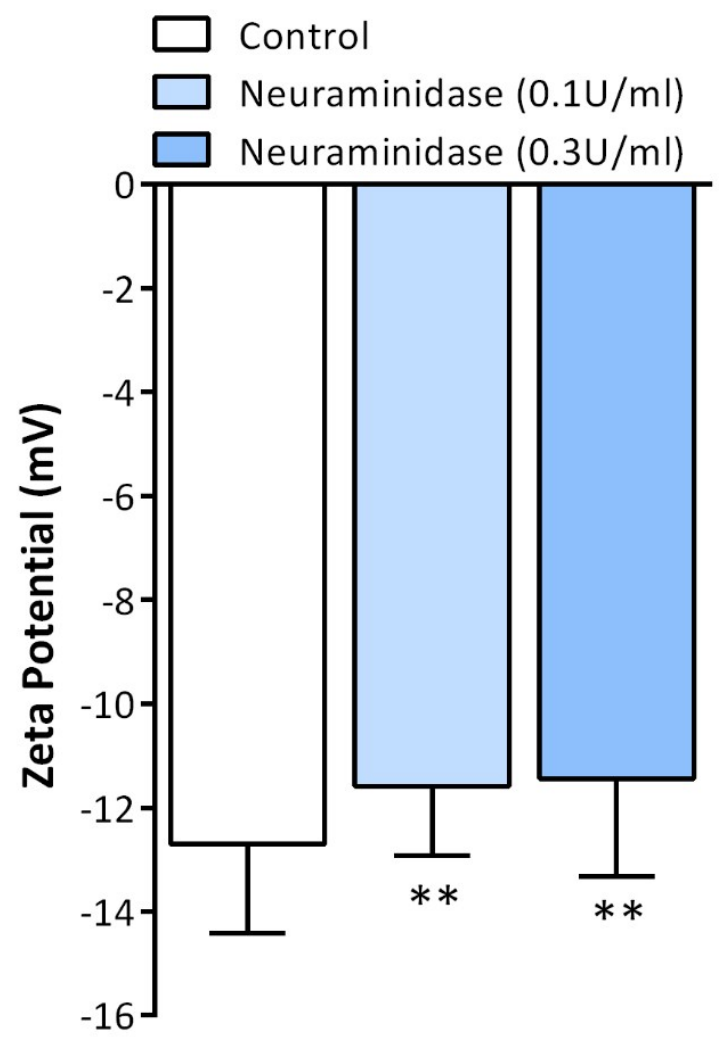

ESI Figure S4 The effect of neuraminidase concentrations (0.1 and $0.3 \mathrm{U} / \mathrm{ml}$ ) on hCMEC/D3 human brain endothelial cells. Effect of different concentrations of neuraminidase on the surface charge of cells measured by laser-Doppler velocimetry. Values of each group are presented as mean $\pm S D, n=30-66$. Data were analysed by one-way ANOVA followed by Bonferroni post-test. ${ }^{* *}, p<0.01$ compared to the control group.

A

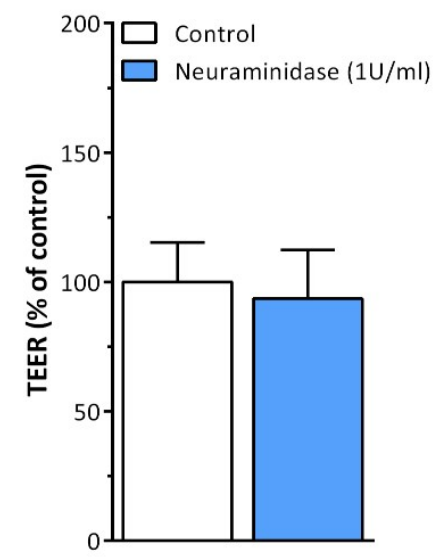

B

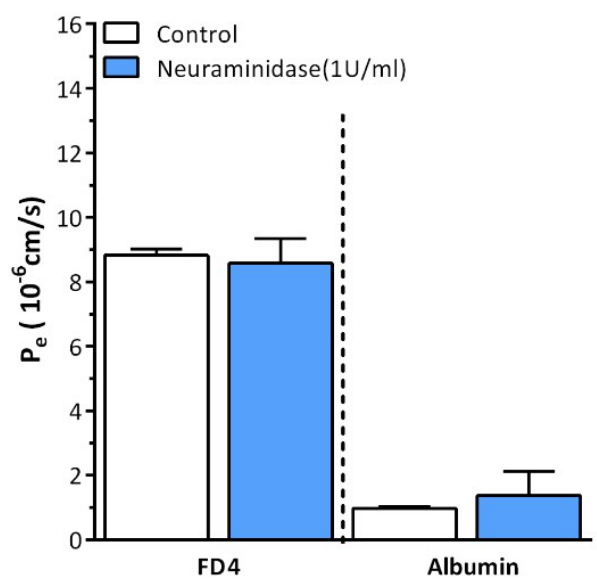

C

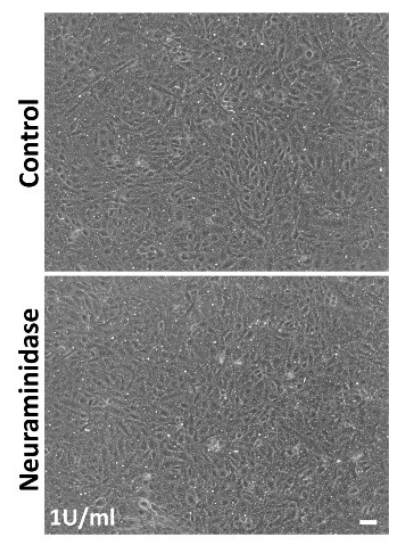

ESI Figure S5 Evaluation of the paracellular barrier integrity of confluent hCMEC/D3 human brain endothelial cell layers cultured on insert after neuraminidase treatment (1U/ml). (A) Transendothelial electrical resistance (TEER) measurements after $1 \mathrm{~h}$ neuraminidase treatment. Values of each group are presented as mean $\pm S D, n=3$. Data were analysed by unpaired t-test, no statistically significant difference was found. (B) Endothelial permeability coefficient $\left(P_{e}\right)$ of cells treated with neuraminidase for two paracellular hydrophilic tracers, 4 kDa FITC-dextran (FD4) and albumin. Values are presented as means $\pm S D, n=3$. Data were analysed by unpaired t-test, no statistically significant difference was observed. (C) Phase contrast pictures of hCMEC/D3 cells after neuraminidase treatment, bar: $20 \mu \mathrm{m}$. No morphological change is visible. 



\section{Publication III}


Transport Studies Using Blood-Brain Barrier

In Vitro Models: A Critical Review

and Guidelines

\author{
Ana R. Santa-Maria, Marjolein Heymans, Fruzsina R. Walter, \\ Maxime Culot, Fabien Gosselet, Maria A. Deli, and \\ Winfried Neuhaus
}

\title{
Contents
}

1 Introduction

2 In Vitro Permeability Measurements

2.1 Apparent Permeability Coefficient

2.2 Endothelial Permeability Coefficient

2.3 Efflux Ratio as a Measurement of Active Efflux

3 Permeability Studies to Measure Barrier Tightness

3.1 Factors Influencing BBB Permeability Results

3.2 Importance of Recovery Values

3.3 Importance of the Materials Used in the Permeability Assay

3.4 Influence of Mechanical Forces

Ana R. Santa-Maria and Marjolein Heymans contributed equally to this work.

\footnotetext{
A. R. Santa-Maria

Institute of Biophysics, Biological Research Centre, Szeged, Hungary

Doctoral School of Biology and Department of Biotechnology, University of Szeged, Szeged, Hungary

M. Heymans · M. Culot $(\bowtie) \cdot$ F. Gosselet

Laboratoire de la Barrière Hémato-Encéphalique (LBHE), UR 2465, University Artois, Lens, France

e-mail: maxime.culot@univ-artois.fr

F. R. Walter

Institute of Biophysics, Biological Research Centre, Szeged, Hungary

Department of Biotechnology, University of Szeged, Szeged, Hungary

M. A. Deli $(\bowtie)$

Institute of Biophysics, Biological Research Centre, Szeged, Hungary

e-mail: deli.maria@brc.hu

W. Neuhaus $(\square)$

Austrian Institute of Technology, Center Health and Bioresources, Vienna, Austria

e-mail: winfried.neuhaus@ait.ac.at

(C) Springer Nature Switzerland AG 2020

Handbook of Experimental Pharmacology, https://doi.org/10.1007/164_2020_394
} 


\subsection{Plasma Protein Binding and Brain Tissue Binding}

3.6 Example of Normalization: Diazepam

4 Transendothelial Electrical Resistance Measurements

5 Conclusion

References

\section{Abstract}

Permeation is one of the most evaluated parameters using preclinical in vitro blood-brain barrier models, as it has long been considered to be one of the major factors influencing central nervous system drug delivery. Blood-brain barrier permeability can be defined as the speed at which a compound crosses the brain endothelial cell barrier and is employed to assess barrier tightness, which is a crucial feature of brain capillaries in vivo. In addition, it is used to assess brain drug penetration. We review traditionally used methods to assess blood-brain barrier permeability in vitro and summarize often neglected in vivo (e.g., plasma protein and brain tissue binding) or in vitro (e.g., culture insert materials or methodology) factors that influence this property. These factors are crucial to consider when performing BBB permeability assessments, and especially when comparing permeability data obtained from different models, since model diversification significantly complicates inter-study comparisons. Finally, measuring transendothelial electrical resistance can be used to describe blood-brain barrier tightness; however, several parameters should be considered while comparing these measurements to the blood-brain barrier permeability to paracellular markers.

\section{Keywords}

Brain capillary endothelial cells · Cell layer tightness · Drug transport · Paracellular transport · Penetration · TEER

\section{Introduction}

Until a decade ago, the focus of many central nervous system (CNS) drug programs was to increase the rate of blood-brain barrier (BBB) permeability, as it was considered to be the main factor determining CNS drug efficacy (Reichel 2010; Banks 2016). However, it became clear that not only rate but also the extent of CNS drug penetration and the intra-brain distribution should be evaluated, as BBB permeability results generally show poor correlation with pharmacodynamic and efficacy readouts (Hammarlund-Udenaes et al. 2008). Current focus is on simultaneous optimization of both rate and extent, and this is in line with the free drug hypothesis (HammarlundUdenaes et al. 2008; Banks 2016). Indeed, many efforts are still being made to improve drug permeation across the $\mathrm{BBB}$, thereby focusing on specific transport systems (Neuhaus et al. 2006; Mahringer et al. 2012; He et al. 2018). 
Brain penetration of molecules is controlled by the tight BBB endothelium, which results from the presence of functional tight junction proteins that seal adjacent brain endothelial cells to each other. It also depends greatly on the specific compound under study (Neuhaus et al. 2006; Bauer et al. 2014). The tightness of the brain endothelial cell (BEC) monolayer determines the restrictive paracellular permeability potential of the BBB and is therefore one of the most important BBB features, as it critically regulates BBB function (Günzel and Yu 2013). Any disruption of barrier tightness or function can lead to malfunctioning of the brain itself, contributing to different neurodegenerative disorders, including Parkinson's disease and Alzheimer's disease (Montagne et al. 2017; Sweeney et al. 2018).

The high complexity of in vivo models resulted in the development of a vast amount of in vitro approaches mimicking the BBB over the past decades. Therefore, the relationship between cell monolayer tightness and compound penetration is commonly evaluated preclinically using in vitro BBB models (Dehouck et al. 1990, 2011; Deli et al. 2005; Cecchelli et al. 2014; Avdeef et al. 2015; Aday et al. 2016; Helms et al. 2016).

These in vitro BBB models are highly valuable as they provide good tools to study barrier properties in both health and disease, as well as for studying mechanistic aspects related to drug transport (Neuhaus et al. 2006). They all aim to mimic the in vivo BBB; however, they generally reflect it only partially and in variable ways (Reichel et al. 2003; Helms et al. 2016). Model diversification and a further lack of standardization results in inter-study variability and complicates cross-comparison of data obtained from different models. BBB permeability is one of the BBB-related parameters that is often compared indistinctly across studies, which leads to inconsistent observations and misinterpretations (Bischoff et al. 2016). There are only few studies comparing different BBB models using the same permeability methods and set of markers or compounds (Hellinger et al. 2012; Veszelka et al. 2018) and even fewer studies comparing the in vitro BBB permeability results with in vivo brain penetration data (Dehouck et al. 1992; Garberg et al. 2005; Nakagawa et al. 2009). In order to enhance comparability and transferability of BBB permeability data, this chapter reviews the most frequently utilized methods to assess BBB permeability, provides guidelines, and draws the attention on multiple, often neglected, factors that should be considered when employing and comparing BBB permeability studies.

\section{In Vitro Permeability Measurements}

Permeability is a rate parameter that describes the speed at which a compound crosses the BBB. It can be assessed using in vitro BBB models with the purposes (1) to determine brain endothelial barrier tightness (i.e., evaluation of the functionality of complex tight junction proteins) by measuring BBB permeability of a wellknown paracellular integrity marker and (2) to assess BBB penetration of compounds in, for example, CNS drug programs (Youdim et al. 2003; Wegener and Seebach 2014; Yusof et al. 2014). 
BBB permeability of a compound is the result of both paracellular diffusion and transendothelial transport including passive transcellular diffusion of lipophilic molecules, active carrier-mediated transport via solute carriers, and transcytosis by receptor-mediated or non-specific transcytotic pathways (Deli et al. 2005; Abbott et al. 2010; Wegener and Seebach 2014). Paracellular space between neighboring brain endothelial cells is strictly regulated by the unique functionality of complex intercellular tight junctions including transmembrane tight junction and adherens junction proteins which restrict the passage of hydrophilic molecules (Wolburg and Lippoldt 2002; Neuhaus et al. 2006; Abbott et al. 2010; Wegener and Seebach 2014). Depending on their size and lipophilicity, most compounds are therefore transported through transcellular transport and their passive permeation across the lipid plasma membrane (Neuhaus et al. 2006). The parallel artificial membrane permeability assay (PAMPA) can be used to assess passive diffusion across the lipid membrane of the BBB (Ottaviani et al. 2006; Avdeef et al. 2015). However, artificial membranes lack BBB transporters, an issue that can significantly affect predictability of CNS penetration of a drug under study (Avdeef et al. 2015). By contrast, permeability assessment using an in vitro BBB model allows the more accurate reproduction of the complexity of the BBB in vivo, at least to some degree (Garberg et al. 2005; Helms et al. 2016), and may therefore facilitate compound selection in CNS drug discovery programs.

Multiple variants of in vitro BBB permeability experiments exist, but they all rely on the same principle. The transport rate of a molecule is assessed across a confluent cell monolayer, which is seeded on a cell culture insert with a highly permeable membrane. This insert is usually placed in a multiwell plate, thereby forming the interface between two fluid compartments, i.e., one compartment that mimics the blood and one compartment that mimics the brain side. Next, the test compound is added to the donor compartment, which can be one of the two compartments, and is then allowed to be transported across the cell monolayer to the receiver compartment in a defined amount of time, for example, 60 min (Dehouck et al. 2011). The permeability experiment ends with sample collection that is required for calculating BBB permeability. Ideally for translation experiments, the in vitro cell monolayer should be as tight as possible, thereby restricting the paracellular pathway to the highest possible extent, so that the contribution of transendothelial transport can be accurately investigated and estimated (Deli et al. 2005; Hammarlund-Udenaes et al. 2008; Helms et al. 2016). However, most in vitro models of the BBB only show a moderately tight brain endothelial monolayer and therefore reflect contributions of the transcellular pathway and the paracellular pathway. It is thereby often the case that the paracellular transport of especially hydrophilic or amphiphilic compounds represents a significant part of the total transport rate, which renders the study of the cellular and molecular mechanisms behind transendothelial transport extremely difficult.

BBB permeability is commonly calculated by two different types of methods with either consideration of a cell-free insert or not: the endothelial permeability coefficient $\left(\mathrm{P}_{\mathrm{e}}\right)$ and the apparent permeability coefficient $\left(\mathrm{P}_{\mathrm{app}}\right)$, respectively. Examples of 
these methods are explained below together with important factors to consider when comparing permeability data from different studies.

\subsection{Apparent Permeability Coefficient}

The apparent permeability coefficient $\left(\mathrm{P}_{\mathrm{app}}\right.$, in $\left.\mathrm{cm} \mathrm{s}^{-1}\right)$ is the most commonly used calculation method for the in vitro permeability. The parameter can be determined by the rate of appearance or flux $\left(\mathrm{J}\right.$, in $\left.\mathrm{s}^{-1}\right)$ of the compound in the receiver, thereby normalizing for membrane surface area $\left(\mathrm{S}\right.$, in $\left.\mathrm{cm}^{2}\right)$ and initial donor concentration at $\mathrm{t}_{0}\left(\mathrm{C}_{0}\right.$, in $\left.\mathrm{mL}^{-1}\right)($ Eq. 1$)$.

$$
\mathrm{P}_{\text {app }}\left(\mathrm{cm} \mathrm{s}^{-1}\right)=\frac{\mathrm{J}\left(\text { amount }^{-1}\right)}{\mathrm{S}\left(\mathrm{cm}^{2}\right) \cdot \mathrm{C}_{0}\left(\text { amount. }_{\mathrm{mL}}{ }^{-1}\right)}
$$

The $\mathrm{P}_{\text {app }}$ does not calculate the true endothelial permeability coefficient $\left(\mathrm{P}_{\mathrm{e}}\right)$ as it does not correct for the permeability across the cell-free insert. However, dependent on the transport route, the permeability of a compound across a cell-free insert is sometimes negligible, and therefore $\mathrm{P}_{\text {app }}$ is widely used. Nevertheless, the type of insert membrane can affect the permeability coefficient value (especially when comparing lipophilic with hydrophilic compound) which is frequently neglected in studies (Cecchelli et al. 1999; Wegener and Seebach 2014). To overcome this issue, endothelial permeability coefficient $\left(\mathrm{P}_{\mathrm{e}}\right)$ could be calculated.

\subsection{Endothelial Permeability Coefficient}

The endothelial permeability coefficient $\left(\mathrm{P}_{\mathrm{e}}\right.$, in, e.g., $\left.\mathrm{cm} \mathrm{min}{ }^{-1}\right)$ is, like $\mathrm{P}_{\text {app }}$, a calculation method for the permeability coefficient. However, it corrects for permeability across a cell-free culture insert and more closely represents the permeability across the endothelium. Among other factors, this calculation method takes into account that the thickness of the plastic support, on which the cells are cultivated, is significantly higher than the thickness of extracellular matrix (ECM) of the BBB in vivo. For example, plastic membranes of cell culture inserts are on average about $10 \mu \mathrm{m}$ thick, whereas the ECM at the BBB is only about 20-60 nm (Thorne and Nicholson 2006). Therefore, the plastic membrane of the inserts represents an additional diffusion barrier for compounds as compared to the in vivo ECM. The $\mathrm{P}_{\mathrm{e}}$ is calculated based on the clearance principle to obtain a concentrationindependent transport parameter (Siflinger-Birnboim et al. 1987). The cleared volume $(\mathrm{CL}$, in $\mu \mathrm{L})$ is calculated by dividing the diffused amount of compound in the receiver compartment $\left(\mathrm{A}_{\mathrm{r}}\right)$ with the concentration of compound in the donor compartment $\left(\mathrm{C}_{\mathrm{d}}\right)$ (Eq. 2). 


$$
\mathrm{CL}(\mu \mathrm{L})=\frac{\mathrm{A}_{\mathrm{r}}}{\mathrm{C}_{\mathrm{d}}}
$$

The average cumulative CL is subsequently plotted over time and the slope is estimated by linear regression analysis. This results in the permeability-surface area

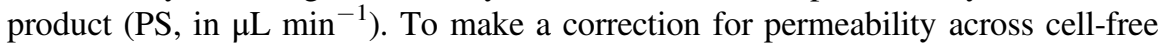
inserts, the PS products are calculated for both cell-free inserts (i.e., $\mathrm{PS}_{\mathrm{f}}$, filter) and inserts with cells (i.e., $\mathrm{PS}_{\mathrm{t}}$, total $=\mathrm{PS}_{\mathrm{f}}+\mathrm{PS}_{\mathrm{e}}$ ).

The $\mathrm{P}_{\mathrm{e}}$ can then be computed out of $\mathrm{PS}_{\mathrm{f}}$ and $\mathrm{PS}_{\mathrm{t}}$ (Eq. 3), normalized by the surface (S, in $\mathrm{cm}^{2}$ ) (Eq. 4) (Garberg et al. 2005; Dehouck et al. 2011; Cecchelli et al. 2014).

$$
\begin{aligned}
& \mathrm{PS}_{\mathrm{e}}^{-1}=\mathrm{PS}_{\mathrm{t}}^{-1}-\mathrm{PS}_{\mathrm{f}}{ }^{-1} \\
& \mathrm{P}_{\mathrm{e}}\left(\mathrm{cm} \mathrm{min}{ }^{-1}\right)=\frac{\mathrm{PS}_{\mathrm{e}}}{\mathrm{S}}
\end{aligned}
$$

\subsection{Efflux Ratio as a Measurement of Active Efflux}

The $\mathrm{P}_{\text {app }}$ coefficient can give information on active efflux. In this type of bidirectional permeability assay, the transport of a compound is assessed in both directions (apical to basolateral (A-B) and basolateral to apical (B-A)) across the cell monolayer. This enables the calculation of the so-called efflux ratio, i.e., $\mathrm{P}_{\text {app }}(\mathrm{B}-\mathrm{A}) / \mathrm{P}_{\text {app }}$ (A-B), which indicates whether or not active efflux is occurring for the compound under study. An efflux ratio greater than 2 indicates drug efflux (Hellinger et al. 2012). Reference compounds which are known efflux pump substrates, for example, talinolol, can be assessed in parallel. In addition, slow permeating compounds like atenolol or fast, transcellularly permeating drugs such as propranolol are frequently used in these assays as marker substances. Additionally, including reference compounds of active efflux, efflux pump inhibitors (e.g., verapamil for P-glycoprotein/ABCB1, MK571 for multidrug resistance proteins (MRPs)/ ABCCs) can also be included in the study. If the test compound is an efflux pump substrate, the efflux should decrease in presence of an inhibitor of the efflux pump under study. This type of assay could also be used to assess active influx processes. In this case, an efflux ratio lower than 0.5 is a hint for an active influx transport.

\section{Permeability Studies to Measure Barrier Tightness}

When the goal is to evaluate the tightness of the brain endothelial monolayer, for example, to validate the permeability status or quality of an in vitro model, a typical integrity marker with low permeability is used. These markers are commonly characterized by their high hydrophilicity, high polarity, and absence of active transport. Therefore they are ideal probes to assess the contribution of the paracellular diffusion pathway, since the permeability will then only be determined 
by the functionality of the cell junctions (Deli et al. 2005; Neuhaus et al. 2006; Wegener and Seebach 2014). The specific permeability value relies also on the properties of the tracer itself, including the type of molecule and molecular size. Several markers are currently on the market such as fluorescent markers including lucifer yellow (442 Da), sodium fluorescein (376 Da), and fluorescein isothiocyanate (FITC)-labeled dextrans $(1-150 \mathrm{kDa})$ and radiolabeled markers including sucrose (342 Da), albumin (67 kDa), mannitol (182 Da), and inulin (5 kDa) (Neuhaus et al. 2006; Saunders et al. 2014; Helms et al. 2016).

Typically, one marker is used to assess the tightness of a BEC monolayer. The choice of the paracellular marker is often dependent on the experimental design and the barrier status of the cell layers. Smaller markers are preferred to study tighter cell layers, whereas bigger markers are used for cell layers with moderate to weak tightness. However, the usage of only one marker does not necessarily allow complete characterization of the paracellular permeability of both small and large molecules. Therefore, Neuhaus et al. developed a tool that characterizes paracellular transport or tightness of cell layers by employing a molecular weight ladder, the 8-aminopyrene-1,3,6-trisulfonate (APTS)-dextran ladder (Neuhaus et al. 2006).

Co-incubation of integrity markers with test compounds like neuropharmaceuticals allows the study of barrier toxicity of compounds. This method is therefore used to qualitatively assess barrier properties of a particular in vitro method. When comparing values obtained with this kind of method across studies, for data interpretation, it is essential to consider possible differences in type or molecular weight of the applied markers (Neuhaus et al. 2006).

\subsection{Factors Influencing BBB Permeability Results}

Modern model diversification hampers inter-study comparability of permeability results. However, generating a better understanding of the different factors that might influence BBB permeability can at least create awareness when comparing data. Inter-variability of in vitro models can originate from differences in isolation procedures of primary cells, cell culture conditions (e.g., assay format, medium), cell culture configuration (e.g., monoculture, co-culture, etc.) and origin (e.g., cell type, species), and experimental design (e.g., buffer, presence of plasma proteins, mechanical forces) (Reichel et al. 2003; Youdim et al. 2003). When the aim is to predict human in vivo findings, neglecting these factors might affect permeability and, so, the quality of the in vitro-in vivo correlation (Yusof et al. 2014; Avdeef et al. 2015). In general, considering these factors is helpful to produce relevant and comparable data that contributes to our knowledge of the in vivo BBB and that can be used in drug development programs for the production of reliable pharmacokinetic information of drugs and drug candidates. 


\subsection{Importance of Recovery Values}

Assessing the mass balance or recovery (\%) of the tracer or drug is essential. Poor solubility or binding to cell assay materials might result in loss of compound throughout the experiment and lead to an underestimation of the endothelial permeability. Poor recovery can result from adsorption of the tested molecule to materials (e.g., plastic), from metabolization by metabolic enzymes, from non-specific binding to cells, and from accumulation in the cell monolayer. Recovery is easily calculated out of the recovered amount of compound in both compartments at the end of the experiment as a percentage of the initial donor amount at $t_{0}$. In addition, intracellular accumulation can be assessed when recovery values suggest poor recovery. The latter can subsequently be applied to determine whether or not the observed poor recovery is a consequence of compound binding to the cell monolayer.

Several groups adopted a quality threshold for permeability experiments, which can differ depending on the experiment and model. For example, Cecchelli et al. determined a mass balance threshold between $80 \%$ and $120 \%$ for the permeability values to be qualitative when using a human in vitro BBB model derived from hematopoietic stem cells (Cecchelli et al. 2014).

Poor recovery can be diminished by including serum albumin during the permeability assay as an absorptive driving force for lipophilic compounds and therefore to mimic the in vivo sink for lipophilic compounds (Youdim et al. 2003; Yusof et al. 2014). Addition of serum albumin in the experimental assay reduces non-specific binding of compound at the donor compartment but also influences the unbound concentration of compounds in the donor compartment, and both factors can influence its transport to the receiver compartment (Yusof et al. 2014).

\subsection{Importance of the Materials Used in the Permeability Assay}

Materials used during the permeability experiment can affect the permeability of compounds across the brain endothelial monolayer (Cecchelli et al. 1999; Wegener and Seebach 2014; Yusof et al. 2014). For example, permeability across a cell-free culture insert can provide essential information about how the membrane of the insert potentially influences permeability values. To ensure proper calculation of $\mathrm{P}_{\mathrm{e}}$, permeability across the cell-free insert should not be the rate-limiting step in a compound's diffusion process. The insert membrane should be highly permeable for the concerned compound, but at the same time, it should still support the cell layer mechanically (Cecchelli et al. 1999; Wegener and Seebach 2014). For this, pore size and membrane material are important parameters to consider as they can lead to divergent permeability values across studies using different inserts (Cecchelli et al. 1999; Yusof et al. 2014). Furthermore, assessing the MB in a cell-free experiment provides an efficient way to evaluate compound binding to materials. For example, transport tests with lipophilic ester compounds against trypanosome infections across cell-free PET membranes showed a significant loss of the substances within the plastic membranes (Cohrs 2008). Finally, this required an 
adjustment of the plastic material and the cell seeding and culture procedure using hydrophilic PTFE (Teflon).

Another parameter to consider is the $\mathrm{pH}$ of the medium or buffer, as it is known to affect permeability when assessing the penetration of ionizable compounds like vinblastine, acetylsalicylic acid, and naloxone (Youdim et al. 2003; Yusof et al. 2014). In this regard, it should be mentioned that the medium composition could also influence the barrier properties of the cell layers; thus caution and control experiments for cell viability and the targeted transport process should be conducted to improve the interpretability of the results. For example, serum content not only affects the transport study results by different drug binding to serum proteins; it might also influence the barrier properties of the cell layer itself by, e.g., supplying different amounts of growth factors.

\subsection{Influence of Mechanical Forces}

Static in vitro models of the BBB do not reflect the physiological conditions in which the in vivo BBB operates, such as lack of cerebral blood flow and shear stress. In the last 8 years, new dynamic in vitro BBB models have emerged based on microfluidic devices to assess permeability of molecules. Similar to in vivo conditions, these flow models incorporate mechanical forces, i.e., shear stress, hydrostatic pressure, and cyclic stretch, that are reported to affect permeability by an overall reduction (Booth and Kim 2014; Wegener and Seebach 2014; Walter et al. 2016; Cochrane et al. 2019). This change in permeability mainly results from tightening of brain endothelial cell junctions, and its intensity depends on the cell type and experimental design (Wegener and Seebach 2014; Walter et al. 2016).

Many static in vitro models are currently being employed, and it is therefore necessary to consider other important factors that affect BBB permeability which follow from this static condition. Cell monolayers in static models show the presence of an aqueous boundary layer, adjacent to the cell layer, which is absent or minimal in in vivo conditions due to the existing blood circulation (Youdim et al. 2003). The absence of flow in vitro generates a concentration gradient between the compound in the upper part of the buffer or medium and the compound close to the membrane surface. The layer that results, the unstirred water layer, is recognized to affect $\mathrm{P}_{\text {app }}$ and $\mathrm{P}_{\mathrm{e}}$ of compounds (Youdim et al. 2003). In particular, fast permeating, lipophilic compounds are hampered by this extra aqueous layer which might be the ratelimiting step for permeation of these compounds (Korjamo et al. 2008). This can lead to deviation from in vivo permeation values by underestimation of the permeability (Youdim et al. 2003; Yusof et al. 2014). Formation of this aqueous layer can be reduced by a stirring or shaking procedure during the permeability assay. However, complete reduction of this layer is difficult as a shaking velocity that is too high will compromise the endothelial barrier function by affecting tight junction integrity, and a shaking velocity that is too low will not efficiently reduce the aqueous-boundary effect, and hence a balance should be made (Yusof et al. 2014; Avdeef et al. 2015). Besides this, each compound is characterized by different 
physio-chemical characteristics and may require different shaking speeds. Some correction procedures for permeability values have been reported, for example, the pCEL-X software correction method (Yusof et al. 2014).

\subsection{Plasma Protein Binding and Brain Tissue Binding}

In line with the free drug hypothesis, only the unbound compound is available for permeation across the brain capillary endothelial monolayer. However, compounds that are weakly bound to proteins such as albumin may still interact with membrane transporters. Thus the total biologically available compound is the sum of the unbound fraction and the weakly bound fraction (Banks 2016). This interaction depends on the compound's affinity for both the transporter and for proteins such as human serum albumin (Pajouhesh and Lenz 2005). Therefore, comparing in vitro BBB permeability of compounds from studies for which differences are present in the buffer or medium composition regarding the presence of plasma or serum proteins is cumbersome as BBB penetration has been demonstrated to be affected by protein binding (Pajouhesh and Lenz 2005). The latter should also be considered while comparing in vitro to in vivo data as plasma protein binding also influences other pharmacokinetic parameters of the drug, such as the half-life or volume of distribution, affecting BBB drug exposure (Banks 2016).

Similar discrepancies result when comparing studies that differentially mimicked potential brain tissue binding. Brain tissue binding is known to affect in particular the permeability of lipophilic compounds. This is not accounted for in the classical methods to assess permeability like $\mathrm{P}_{\mathrm{app}}$ or $\mathrm{P}_{\mathrm{e}}$, leading to a poor in vitro-to-in vivo translation for those compounds characterized by high brain tissue binding (Summerfield et al. 2007; Heymans et al. 2018). In vitro, this discrepancy can be minimalized by implementing glial cells, or very likely also other cells, in the receiver compartment that allow potential brain tissue binding. The latter requires the use of an adjusted permeability calculation resulting in a novel in vitro permeability coefficient, named $P_{\text {vitro }}$ (Heymans et al. 2018).

\subsection{Example of Normalization: Diazepam}

The lipophilic compound diazepam is known to permeate rapidly into the brain using passive diffusion and is therefore extensively used as an internal standard for the assessment of transcellular, passive transport (Neuhaus et al. 2006; Culot et al. 2008). When comparing permeability using different in vitro models, diazepam is expected to result in a similar outcome, since it permeates very rapidly across a lipid bilayer through passive diffusion (Neuhaus et al. 2006). Therefore, very divergent permeability results for diazepam might indicate the significant influence of one or several factors on BBB permeability (described in Sects. 3.1-3.5) in one of the models under study. This was, for example, demonstrated by Zhang et al., who measured the permeability of diazepam in different, i.e., stirred vs. unstirred, 
experimental conditions (Zhang et al. 2006). In this regard, some groups applied diazepam as marker compound within the same experiment in order to normalize for cell layer variabilities of single culture inserts (Appelt-Menzel et al. 2017). To assess the influence of the blank, cell-free insert membrane $\left(\mathrm{PS}_{\mathrm{f}}\right)$ on the permeability coefficient of a compound, the so-called effect of correction could be used.

The effect of correction is calculated by the ratio of $\mathrm{PS}_{\mathrm{e}}$ and $\mathrm{PS}_{\mathrm{t}}$. When this ratio equals one, the cell-free insert is considered to have no significant influence, and the brain endothelial monolayer is the major transport barrier. The compound in question must therefore most likely permeate this barrier paracellularly. In contrast to this, diazepam reveals effect of correction values significantly higher than 1 indicating a fast, transcellular transport with a significant influence of the plastic membrane to the total permeability coefficient (Neuhaus et al. 2006).

In addition to being a reference compound that reflects high permeability, it is useful to implement a control compound characterized by a low permeability in a way to relatively compare the permeability of different compounds, rather than compare them based on their absolute permeability value.

\section{$4 \quad$ Transendothelial Electrical Resistance Measurements}

The transendothelial electrical resistance (TEER) measurement is an additional method to evaluate the barrier tightness of in vitro BBB models (Deli et al. 2005; Wegener and Seebach 2014; Helms et al. 2016). TEER represents the paracellular permeability for small inorganic ions (i.e., $\mathrm{Na}^{+}$and $\mathrm{Cl}^{-}$) and can be defined as a measure of electrical/ohmic resistance of ion flow across the cell monolayer (Neuhaus et al. 2006; Abbott et al. 2014). In accordance with Ohm's law, it is a direct current (DC) approach: voltage (U) is applied to two electrodes, from which one is above and the other one is under the cell layer enabling the ion current (I) measurement across the monolayer resulting in the recording of ohmic resistance ( $\mathrm{R}=\mathrm{U} / \mathrm{I})$ (Benson et al. 2013).

The two most common electrode types to measure TEER on BBB models grown on culture inserts are the chopstick (Fig. 1a) and chamber electrodes (Fig. 1b). One of the electrodes reaches the bottom compartment, assuring a stable position. The shorter electrode submerges into the medium in the top compartment but does not reach the cell layer. The handling of chopstick electrodes is fast and easy, but their positioning is key for reproducibility. The positioning angle, medium volume used, and the small interferences between measurement conditions, such as temperature and $\mathrm{pH}$ changes, can be a drawback of this method. Therefore, it is recommended to change the medium before each measurement and equilibrate the temperature by, e.g., incubating at room temperature for 30-45 $\mathrm{min}$ in the sterile working bench (Blume et al. 2010). This is generally considered as essential, since the composition (serum content, ion composition, viscosity (Gerhartl et al. 2020)), the age, and the temperature of the medium could influence the measured values significantly. In addition, it is also important to assess blank values without cells under the very same conditions (same age, same coating, same medium, etc.). Chamber electrodes have a 

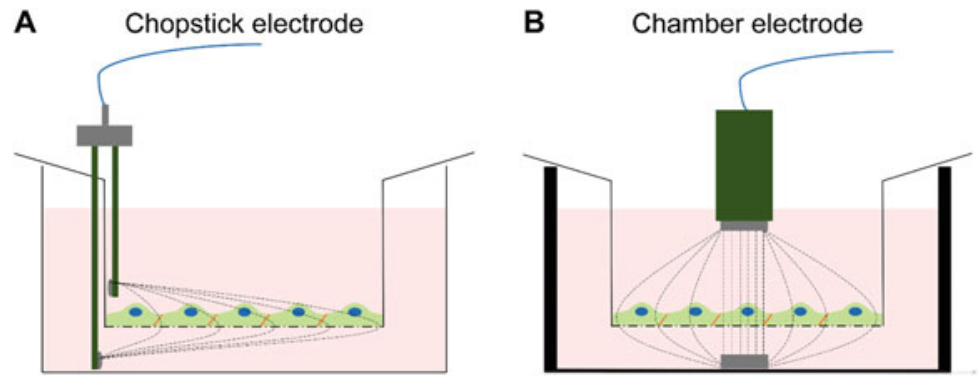

Fig. 1 Electrode types for transendothelial electrical resistance (TEER) measurements on BBB models using culture inserts. (a) Chopstick electrodes. (b) Chamber electrodes. The figures were adapted from the EVOM2 instruction manual (World Precision Instruments, Sarasota, FL, USA)

more uniform current density across the insert membrane (Fig. 1b) resulting in low background TEER values across cell-free inserts. In general, the TEER values measured across cell-free inserts are ten times higher in the case of chopstick electrodes as compared to chamber electrodes. Modified versions of the chamber electrodes were developed (cellZscope, nanoAnalytics, Germany) to measure TEER in different multiwell format inserts (Benson et al. 2013).

Using DC for TEER measurement can result in the accumulation of ions at electrode and the cell layer; therefore the commonly used Epithelial Voltohmmeter (EVOM; World Precision Instruments) uses alternate current (AC) at a very low $(12.5 \mathrm{~Hz})$ frequency. When we measure TEER with AC, we register impedance. In this method the capacitance of the cell layer is also taken into account when calculating resistance. The total impedance reflects not only the TEER (paracellular ion pathway) of the cell layer but the resistance of the membrane (transcellular ion pathway), the medium itself, and the surface where the electrode and medium meet (Benson et al. 2013). It is important to note that the used frequency of the AC square wave current defines the information gained from the measurement. At low frequency $(\leq 400 \mathrm{~Hz})$, the paracellular ion current pathway is the dominant, and the impedance reflects cell-cell junction strength. At higher AC frequency $(\geq 10 \mathrm{kHz})$, impedance measurement reflects the current pathway across cell membranes (Benson et al. 2013).

In experiments the TEER measurement is widely used as a quality control to select culture inserts with consistent and comparable cell monolayers representing similar integrity for further experiments (Reichel et al. 2003; Deli et al. 2005; Abbott et al. 2014; Helms et al. 2016). Thereby, studies generally adopt a TEER quality threshold to exclude cell culture inserts showing low integrity, but these threshold values can be very different depending on the BBB models (Gaillard and de Boer 2000; Abbott et al. 2014; Helms et al. 2016). Besides its use in quality control, the TEER method is employed in studies to identify agents that modulate barrier tightness (Bocsik et al. 2019; Santa-Maria et al. 2019). Moreover, supplements like lithium chloride (Veszelka et al. 2018), cAMP, or hydrocortisone influence TEER in different BBB models from different species (Deli et al. 2005). As shown in 
Table 1 TEER values of in vitro models of the blood-brain barrier from different species

\begin{tabular}{l|l|l|l}
\hline Species & Type of endothelial cells & Co-culture & $\begin{array}{l}\text { TEER } \\
\left(\Omega \times \mathrm{cm}^{2}\right)\end{array}$ \\
\hline Mouse & Primary BEC & Astrocyte & $777 \pm 15$ \\
\hline Mouse & cEND cell line & - & $300-800$ \\
\hline Mouse & cerebEND cell line & - & $500 \pm 10$ \\
\hline Rat & Primary BEC & Astrocyte & $300-600$ \\
\hline Rat & Primary BEC & $\begin{array}{l}\text { Brain pericytes and } \\
\text { astrocytes }\end{array}$ & $350-723$ \\
\hline Bovine & Primary BEC & Rat astrocyte & $600-1,600$ \\
\hline Bovine & Primary BEC (clone selection) & Rat astrocyte & $600-800$ \\
\hline Porcine & Primary BEC (isolation using enzymes) & - & $250-790$ \\
\hline Porcine & $\begin{array}{l}\text { Primary BEC (isolation with density } \\
\text { centrifugation) }\end{array}$ & - & $400-1,500$ \\
\hline Porcine & Primary BEC & $\begin{array}{l}\text { Rat astrocyte/astrocyte } \\
\text { cell line }\end{array}$ & $800-1,800$ \\
\hline Human & hCMEC/D3 cell line & - & $40-200$ \\
\hline Human & iPSCs & - & $220 \pm 51$ \\
\hline Human & iPSCs & Astrocyte & $700 \pm 112$ \\
\hline Human & iPSCs & $\begin{array}{l}\text { Brain pericytes and } \\
\text { primed NPC }\end{array}$ & $2,500-5,350$ \\
\hline Human & CD34 ${ }^{+}$-derived EC & - & $60-90$ \\
\hline Human & CD34 ${ }^{-}$-derived EC & Brain pericytes & $150-180$ \\
\hline
\end{tabular}

Type of brain endothelial cells and co-culture with astrocytes and/or pericytes are indicated. Data are collected and adapted from Helms et al. (2016)

$B E C$ Brain endothelial cell, $E C$ endothelial cell, $c E N D$ immortalized cerebral endothelial cell, cerebEND immortalized cerebellum endothelial cells, $h C M E C / D 3$ immortalized human brain endothelial cells, iPSCs induced pluripotent stem cells, CD $34^{+}$cord-blood CD34 ${ }^{+}$stem cellderived endothelial cells, NPC neural progenitor cells

Table 1, co-culture and primary cell-based models present a higher TEER compared to monolayer or cell line models.

In general the TEER value measured depends on areas of the monolayer which possess the lowest electrical resistance, whereas BBB permeability depends on the total transport using all junctional or transport pathways (Deli et al. 2005). TEER is nonlinearly related to permeability coefficients (Fig. 2) (Gaillard and de Boer 2000; Neuhaus et al. 2006; Abbott et al. 2014; Thomsen et al. 2015).

More specifically, this relationship tends to be inverse. Permeability is related to conductance $(\mathrm{g})$ that measures both ionic permeability across a cell layer and the total number of available ions, which is the reciprocal of resistance (Abbott et al. 2014). For example, leakiness of the brain endothelial monolayer may occur upon decreasing tight junction protein functionality, which therefore results in a higher $\mathrm{P}_{\mathrm{e}}$ to an integrity marker and a generally lower TEER. However, brain capillary endothelial monolayers characterized by low TEER values fail to show this relationship as demonstrated by highly variable and inconsistent $\mathrm{P}_{\mathrm{e}}$ or $\mathrm{P}_{\text {app }}$ values (Abbott et al. 2014; Bischoff et al. 2016). For low resistance cells or models therefore, it is 
A

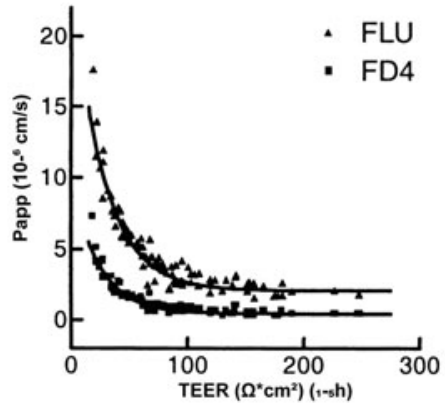

B

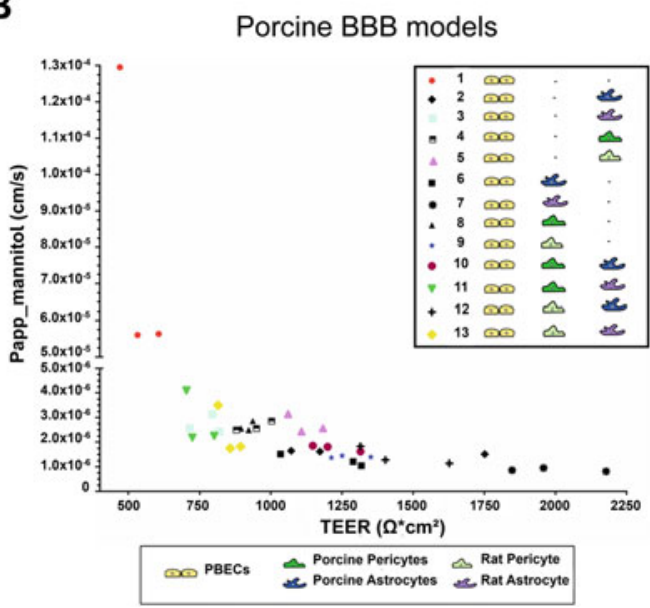

Fig. 2 Correlation of apparent permeability coefficients $\left(\mathrm{P}_{\mathrm{app}}\right)$ and transendothelial electrical resistance (TEER) on in vitro blood-brain barrier (BBB) co-culture models. (a) Primary brain endothelial cells of bovine origin were co-cultured with primary rat astrocytes. In vitro permeability for sodium fluorescein (FLU) and FITC-labeled $4 \mathrm{kDa}$ dextran (FD4) was assessed for 1-5 h (figure reprinted from Gaillard and de Boer (2000)). (b) Primary porcine brain endothelial cells (PBECs) in monoculture or co-cultured with primary porcine or rat pericytes and astrocytes (figure reprinted from Thomsen et al. (2015))

more convenient to employ permeability studies (Bischoff et al. 2016). It was suggested by some studies (Fig. 2) that as a general threshold, a TEER bigger than $150 \Omega \times \mathrm{cm}^{2}$ should be adopted to ensure independence of $\mathrm{P}_{\text {app }}$ (Gaillard and De Boer 2000; Neuhaus et al. 2006). Hence, caution should be made when interpreting data obtained from leaky brain capillary endothelial monolayers (Bischoff et al. 2016). Besides this, time is another factor to be taken into account when relating TEER and permeability values, as the TEER method evaluates barrier tightness in real time compared to BBB permeability that evaluates barrier tightness for a given period of time (e.g., 30 or $60 \mathrm{~min}$ ) (Wegener and Seebach 2014).

\section{Conclusion}

Over the past 20 years, many efforts were made to develop BBB in vitro models; however, much less attention has been paid to the comparison of data obtained by using these different models. As a consequence, comparison of data such as BBB permeability or transendothelial electrical resistance obtained with different models is cumbersome. Currently, low transferability and incompatibility of outcomes obtained by different in vitro models is the rule.

Tightness of the brain endothelial cell monolayer is one of the most critical BBB feature as it is the main contributor to proper BBB functioning. Methods, such as 
BBB permeability tests, to assess barrier tightness in vitro are therefore broadly used. However, current model diversification results in inter-study variation which complicates the comparison of permeability values, as even subtle changes in, for example, cell culture conditions, experimental design, or methodology can result in significantly different outcomes. Because the list of in vitro models is still expanding, it is essential to always be aware of the different factors that potentially influence BBB permeability, especially when comparisons are made with data from other studies. From this aspect, a standardization of culture conditions and methodology would be highly beneficial and would very likely decrease the high prevalence of the current inter-laboratory variation. To compare permeability values, the implementation of a standardized ranking method by using control compounds that reflect a high- and low-permeability compound would be instrumental (Neuhaus et al. 2006). This would make it possible to compare relative permeability data rather than using absolute permeability values.

This chapter, describing the neglected factors relevant to in vitro BBB models, may help in a better understanding and prediction of the in vivo permeability of compounds.

Acknowledgments The authors (ARSM, MH, MD, MC) were supported by the European Commission within the framework of a Marie Sklodowska-Curie Innovative Training Network: BtRAIN - European Brain Barriers Training Network (H2020-MSCA-ITN-2015, n675619). MD and ARSM were supported by the M-ERA.NET2 nanoPD project financed by the National Research, Development and Innovation Office, Hungary (OTKA NNE 129617), and the Hungarian Academy of Sciences. ARSM received an ÚNKP-20-4-SZTE-593 fellowship. FW was supported by the János Bolyai Research Fellowship of the Hungarian Academy of Sciences; the National Research, Development and Innovation Office, Hungary (OTKA PD-128480); the ÚNKP-19SZTE42 and ÚNKP-20-5-SZTE-672, Bolyai + Scholarship New National Excellence Program of the Ministry for Innovation and Technology. WN was supported by the SET foundation project 060. This project has received funding from the Innovative Medicines Initiative 2 Joint Undertaking under grant agreement No 807015. This Joint Undertaking receives support from the European Union's Horizon 2020 research and innovation program and EFPIA (WN).

\section{References}

Abbott NJ, Patabendige AA, Dolman DE, Yusof SR, Begley DJ (2010) Structure and function of the blood-brain barrier. Neurobiol Dis 37(1):13-25. https://doi.org/10.1016/j.nbd.2009.07.030

Abbott NJ, Dolman DEM, Yusof SR, Reichel A (2014) In vitro models of CNS barriers. In: Hammarlund-Udenaes M, de Lange E, Thorne R (eds) Drug delivery to the brain. AAPS advances in the pharmaceutical sciences series, vol 10. Springer, New York. https://doi.org/ 10.1007/978-1-4614-9105-7_6

Aday S, Cecchelli R, Hallier-Vanuxeem DTDIF, Dehouck MP, Ferreira L (2016) Stem cell-based human blood-brain barrier models for drug discovery and delivery. Trends Biotechnol 34 (5):382-393. https://doi.org/10.1016/j.tibtech.2016.01.001

Appelt-Menzel A, Cubukova A, Günther K, Edenhofer F, Piontek J, Krause G, Stüber T, Walles H, Neuhaus W, Metzger M (2017) Establishment of a human blood-brain barrier co-culture model mimicking the neurovascular unit using induced Pluri- and multipotent stem cells. Stem Cell Rep 8(4):894-906. https://doi.org/10.1016/j.stemcr.2017.02.021 
Avdeef A, Deli MA, Neuhaus W (2015) In vitro assays for assessing BBB permeability: artificial membrane and cell culture models. In: Di L, Kerns EH (eds) Blood-brain barrier in drug discovery: optimizing brain exposure of drugs and minimizing brain side effects. Wiley, Hoboken, pp 188-237. https://doi.org/10.1002/9781118788523.ch10

Banks WA (2016) From blood-brain barrier to blood-brain interface: new opportunities for CNS drug delivery. Nat Rev Drug Discov 15(4):275. https://doi.org/10.1038/nrd.2015.21

Bauer HC, Krizbai IA, Bauer H, Traweger A (2014) "You Shall Not Pass"-tight junctions of the blood brain barrier. Front Neurosci 8:392. https://doi.org/10.3389/fnins.2014.00392

Benson K, Cramer S, Galla HJ (2013) Impedance-based cell monitoring: barrier properties and beyond. Fluids Barriers CNS 10(1):5. https://doi.org/10.1186/2045-8118-10-5

Bischoff I, Hornburger MC, Mayer BA, Beyerle A, Wegener J, Fürst R (2016) Pitfalls in assessing microvascular endothelial barrier function: impedance-based devices versus the classic macromolecular tracer assay. Sci Rep 6:23671. https://doi.org/10.1038/srep23671

Blume LF, Denker M, Gieseler F, Kunze T (2010) Temperature corrected transepithelial electrical resistance (TEER) measurement to quantify rapid changes in paracellular permeability. Pharmazie 65(1):19-24

Bocsik A, Gróf I, Kiss L, Ötvös F, Zsíros O, Daruka L, Fülöp L, Vastag M, Kittel Á, Imre N, Martinek TA, Pál C, Szabó-Révész P, Deli MA (2019) Dual action of the PN159/KLAL/MAP peptide: increase of drug penetration across Caco-2 intestinal barrier model by modulation of tight junctions and plasma membrane permeability. Pharmaceutics 11(2):73. https://doi.org/10. 3390/pharmaceutics11020073

Booth R, Kim H (2014) Permeability analysis of neuroactive drugs through a dynamic microfluidic in vitro blood-brain barrier model. Ann Biomed Eng 42(12):2379-2391. https://doi.org/10. 1007/s10439-014-1086-5

Cecchelli R, Dehouck B, Descamps L, Fenart L, Buée-Scherrer V, Duhem C, Lundquist S, Rentfel M, Torpier G, Dehouck MP (1999) In vitro model for evaluating drug transport across the blood-brain barrier. Adv Drug Deliv Rev 36(2-3):165-178. https://doi.org/10.1016/S0169409X(98)00083-0

Cecchelli R, Aday S, Sevin E, Almeida C, Culot M, Dehouck L, Coisne C, Engelhardt B, Dehouck MP, Ferreira L (2014) A stable and reproducible human blood-brain barrier model derived from hematopoietic stem cells. PLoS One 9(6):e99733. https://doi.org/10.1371/journal.pone. 0099733

Cochrane A, Albers HJ, Passier R, Mummery CL, van den Berg A, Orlova VV, van der Meer AD (2019) Advanced in vitro models of vascular biology: human induced pluripotent stem cells and organ-on-chip technology. Adv Drug Deliv Rev 140:68-77. https://doi.org/10.1016/j.addr. 2018.06.007

Cohrs B (2008) Untersuchungen zur Überwindung der Blut-Hirn Schranke von Wirkstoffen gegen Trypanosomeninfektionen. Diploma thesis, Kiel University, Germany

Culot M, Lundquist S, Vanuxeem D, Nion S, Landry C, Delplace Y, Dehouck MP, Berezowski V, Fenart L, Cecchelli R (2008) An in vitro blood-brain barrier model for high throughput (HTS) toxicological screening. Toxicol In Vitro 22(3):799-811. https://doi.org/10.1016/j.tiv.2007.12. 016

Dehouck MP, Méresse S, Delorme P, Fruchart JC, Cecchelli R (1990) An easier, reproducible, and mass-production method to study the blood-brain barrier in vitro. J Neurochem 54 (5):1798-1801. https://doi.org/10.1111/j.1471-4159.1990.tb01236.x

Dehouck MP, Jolliet-Riant P, Brée F, Fruchart JC, Cecchelli R, Tillement JP (1992) Drug transfer across the blood-brain barrier: correlation between in vitro and in vivo models. J Neurochem 58 (5):1790-1797. https://doi.org/10.1111/j.1471-4159.1992.tb10055.x

Dehouck MP, Vandenhaute E, Dehouck L, Sevin E, Lenfant AM, Delplace Y, Hallier-Vanuxeem D, Culot M, Cecchelli R (2011) Modelling the blood-brain barrier. In: Cell culture techniques. Humana Press, Totowa, pp 145-160. https://doi.org/10.1007/978-1-61779-077-5_7

Deli MA, Ábrahám CS, Kataoka Y, Niwa M (2005) Permeability studies on in vitro blood-brain barrier models: physiology, pathology, and pharmacology. Cell Mol Neurobiol 25(1):59-127. https://doi.org/10.1007/s10571-004-1377-8 
EVOM2 Instruction Manual. https://www.wpiinc.com/media/wysiwyg/pdf/EVOM2_IM.pdf. Accessed 30 Sept 2019

Gaillard PJ, de Boer AG (2000) Relationship between permeability status of the blood-brain barrier and in vitro permeability coefficient of a drug. Eur J Pharm Sci 12(2):95-102. https://doi.org/10. 1016/S0928-0987(00)00152-4

Garberg P, Ball M, Borg N, Cecchelli R, Fenart L, Hurst RD, Lindmark T, Mabondzo A, Nilsson JE, Raub TJ, Stanimirovic D, Terasaki T, Oberg JO, Osterberg T (2005) In vitro models for the blood-brain barrier. Toxicol In Vitro 19(3):299-334. https://doi.org/10.1016/j.tiv.2004.06.011

Gerhartl A, Hahn K, Neuhoff A, Friedl HP, Förster CY, Wunder C, Schick M, Burek M, Neuhaus W (2020) Hydroxyethylstarch (130/0.4) tightens the blood-brain barrier in vitro. Brain Res 1727:146560. https://doi.org/10.1016/j.brainres.2019.146560

Günzel D, Yu AS (2013) Claudins and the modulation of tight junction permeability. Physiol Rev 93(2):525-569. https://doi.org/10.1152/physrev.00019.2012

Hammarlund-Udenaes M, Fridén M, Syvänen S, Gupta A (2008) On the rate and extent of drug delivery to the brain. Pharm Res 25(8):1737-1750. https://doi.org/10.1007/s11095-007-9502-2

He Q, Liu J, Liang J, Liu X, Li W, Liu Z, Ding Z, Tuo D (2018) Towards improvements for penetrating the blood-brain barrier-recent progress from a material and pharmaceutical perspective. Cell 7(4):24. https://doi.org/10.3390/cells7040024

Hellinger E, Veszelka S, Tóth AE, Walter F, Kittel A, Bakk ML, Tihanyi K, Háda V, Nakagawa S, Duy TD, Niwa M, Deli MA, Vastag M (2012) Comparison of brain capillary endothelial cellbased and epithelial (MDCK-MDR1, Caco-2, and VB-Caco-2) cell-based surrogate blood-brain barrier penetration models. Eur J Pharm Biopharm 82(2):340-351. https://doi.org/10.1016/j. ejpb.2012.07.020

Helms HC, Abbott NJ, Burek M, Cecchelli R, Couraud PO, Deli MA, Förster C, Galla HJ, Romero IA, Shusta EV, Stebbins MJ, Vandenhaute E, Weksler B, Brodin B (2016) In vitro models of the blood-brain barrier: an overview of commonly used brain endothelial cell culture models and guidelines for their use. J Cereb Blood Flow Metab 36(5):862-890. https://doi.org/10.1177/ $0271678 X 16630991$

Heymans M, Sevin E, Gosselet F, Lundquist S, Culot M (2018) Mimicking brain tissue binding in an in vitro model of the blood-brain barrier illustrates differences between in vitro and in vivo methods for assessing the rate of brain penetration. Eur J Pharm Biopharm 127:453-461. https:// doi.org/10.1016/j.ejpb.2018.03.007

Korjamo T, Heikkinen AT, Waltari P, Mönkkönen J (2008) The asymmetry of the unstirred water layer in permeability experiments. Pharm Res 25(7):1714. https://doi.org/10.1007/s11095-0089573-8

Mahringer A, Reichel V, Ott M, MacLean C, Reimold I, Hollnack-Pusch E, Fricker G (2012) Overcoming the blood brain barrier-the challenge of brain drug targeting. J Nanoneurosci 2 (1):5-19. https://doi.org/10.1166/jns.2012.1012

Montagne A, Zhao Z, Zlokovic BV (2017) Alzheimer's disease: a matter of blood-brain barrier dysfunction? J Exp Med 214(11):3151-3169. https://doi.org/10.1084/jem.20171406

Nakagawa S, Deli MA, Kawaguchi H, Shimizudani T, Shimono T, Kittel A, Tanaka K, Niwa M (2009) A new blood-brain barrier model using primary rat brain endothelial cells, pericytes and astrocytes. Neurochem Int 54(3-4):253-263. https://doi.org/10.1016/j.neuint.2008.12.002

Neuhaus W, Bogner E, Wirth M, Trzeciak J, Lachmann B, Gabor F, Noe CR (2006) A novel tool to characterize paracellular transport: the APTS-dextran ladder. Pharm Res 23(7):1491-1501. https://doi.org/10.1007/s11095-006-0256-Z

Ottaviani G, Martel S, Carrupt PA (2006) Parallel artificial membrane permeability assay: a new membrane for the fast prediction of passive human skin permeability. J Med Chem 49 (13):3948-3954. https://doi.org/10.1021/jm060230+

Pajouhesh H, Lenz GR (2005) Medicinal chemical properties of successful central nervous system drugs. NeuroRx 2(4):541-553. https://doi.org/10.1602/neurorx.2.4.541

Reichel A (2010) The blood-brain barrier and CNS penetration: a drug discovery point of view. Front. Pharmacol. In: Conference abstract: pharmacology and toxicology of the blood-brain barrier: state of the art, needs for future research and expected benefits for the EU. https://doi. org/10.3389/conf.fphar.2010.02.00028 
Reichel A, Begley DJ, Abbott NJ (2003) An overview of in vitro techniques for blood-brain barrier studies. In: The blood-brain barrier. Humana Press, Totowa, pp 307-324. https://doi.org/10. 1385/1-59259-419-0:307

Santa-Maria AR, Walter FR, Valkai S, Brás AR, Mészáros M, Kincses A, Klepe A, Gaspar D, Castanho MARB, Zimányi L, Dér A, Deli MA (2019) Lidocaine turns the surface charge of biological membranes more positive and changes the permeability of blood-brain barrier culture models. Biochim Biophys Acta Biomembr 1861(9):1579-1591. https://doi.org/10.1016/j. bbamem.2019.07.008

Saunders NR, Dreifuss JJ, Dziegielewska KM, Johansson PA, Habgood MD, Møllgård K, Bauer HC (2014) The rights and wrongs of blood-brain barrier permeability studies: a walk through 100 years of history. Front Neurosci 8:404. https://doi.org/10.3389/fnins.2014.00404

Siflinger-Birnboim A, del Vecchio PJ, Cooper JA, Blumenstock FA, Shepard JM, Malik AB (1987) Molecular sieving characteristics of the cultured endothelial monolayer. J Cell Physiol 132 (1):111-117. https://doi.org/10.1002/jcp.1041320115

Summerfield SG, Read K, Begley DJ, Obradovic T, Hidalgo IJ, Coggon S, Lewis AV, Porter RA, Jeffrey P (2007) Central nervous system drug disposition: the relationship between in situ brain permeability and brain free fraction. J Pharmacol Exp Ther 322(1):205-213. https://doi.org/10. 1124/jpet.107.121525

Sweeney MD, Zhao Z, Montagne A, Nelson AR, Zlokovic BV (2018) Blood-brain barrier: from physiology to disease and back. Physiol Rev 99(1):21-78. https://doi.org/10.1152/physrev. 00050.2017

Thomsen LB, Burkhart A, Moos T (2015) A triple culture model of the blood-brain barrier using porcine brain endothelial cells, astrocytes and Pericytes. PLoS One 10(8):e0134765. https://doi. org/10.1371/journal.pone. 0134765

Thorne RG, Nicholson C (2006) In vivo diffusion analysis with quantum dots and dextrans predicts the width of brain extracellular space. Proc Natl Acad Sci U S A 103:5567-5572

Veszelka S, Tóth A, Walter FR, Tóth AE, Gróf I, Mészáros M, Bocsik A, Hellinger É, Vastag M, Rákhely G, Deli MA (2018) Comparison of a rat primary cell-based blood-brain barrier model with epithelial and brain endothelial cell lines: gene expression and drug transport. Front Mol Neurosci 11:166. https://doi.org/10.3389/fnmol.2018.00166

Walter FR, Valkai S, Kincses A, Petneházi A, Czeller T, Veszelka S, Ormos P, Deli MA, Dér A (2016) A versatile lab-on-a-chip tool for modeling biological barriers. Sens Actuators B Chem 222:1209-1219. https://doi.org/10.1016/j.snb.2015.07.110

Wegener J, Seebach J (2014) Experimental tools to monitor the dynamics of endothelial barrier function: a survey of in vitro approaches. Cell Tissue Res 355(3):485-514. https://doi.org/10. 1007/s00441-014-1810-3

Wolburg H, Lippoldt A (2002) Tight junctions of the blood-brain barrier: development, composition and regulation. Vasc Pharmacol 38(6):323-337. https://doi.org/10.1016/S1537-1891(02) 00200-8

Youdim KA, Avdeef A, Abbott NJ (2003) In vitro trans-monolayer permeability calculations: often forgotten assumptions. Drug Discov Today 8(21):997-1003. https://doi.org/10.1016/s13596446(03)02873-3

Yusof SR, Avdeef A, Abbott NJ (2014) In vitro porcine blood-brain barrier model for permeability studies: pCEL-X software pKa FLUX method for aqueous boundary layer correction and detailed data analysis. Eur J Pharm Sci 65:98-111. https://doi.org/10.1016/j.ejps.2014.09.009

Zhang Y, Li CS, Ye Y, Johnson K, Poe J, Johnson S, Bobrowski W, Garrido R, Madhu C (2006) Porcine brain microvessel endothelial cells as an in vitro model to predict in vivo blood-brain barrier permeability. Drug Metab Dispos 34(11):1935-1943. https://doi.org/10.1124/dmd.105. 006437 


\section{Publication IV}


Flow induces glycocalyx-related genes and negative surface charge in a lab-on-achip human blood-brain barrier model

Ana R. Santa-Maria ${ }^{1,2}$, Fruzsina R. Walter ${ }^{1}$, Ricardo Figueiredo ${ }^{3,4}$, András Kincses ${ }^{1,5}$, Judith Vigh ${ }^{1,2}$, Marjolein Heymans ${ }^{6}$, Maxime Culot ${ }^{6}$, Peter Winter ${ }^{3}$, Fabien Gosselet ${ }^{6}$, András Dér ${ }^{1}$, Maria A. Deli ${ }^{1, *}$

${ }^{1}$ Institute of Biophysics, Biological Research Centre, Temesvári krt. 62, H-6726, Szeged, Hungary

${ }^{2}$ Doctoral School of Biology, University of Szeged, Közép fasor 52, H-6726, Szeged, Hungary

${ }^{3}$ GenXPro GmbH, Altenhöferallee 3, D-60438, Frankfurt-Am-Main, Germany

${ }^{4}$ Johann Wolfgang Goethe University Frankfurt, Frankfurt-Am-Main, Germany

${ }^{5}$ Doctoral School of Multidisciplinary Medical Sciences, University of Szeged, Tisza Lajos körút 109., H-6725, Szeged, Hungary

${ }^{6}$ Univ. Artois, UR 2465, Laboratoire de la Barrière Hémato-Encéphalique (LBHE), F62300 Lens, France

* Corresponding author:

Mária A. Deli,

Institute of Biophysics, Biological Research Centre, Temesvári krt 62, H-6726, Szeged, Hungary

Tel. +36-62-599602

e-mail: deli.maria@brc.hu

Running title: Flow induces glycocalyx on human BBB model

Keywords: blood-brain barrier; gene sequencing; glycocalyx; lab-on-a-chip; surface charge 


\begin{abstract}
The highly negatively charged endothelial surface glycocalyx functions as mechanosensor detecting shear forces generated by the blood flow on the luminal side of brain endothelial cells and contributes to the physical barrier of the blood-brain barrier (BBB). Despite the importance of glycocalyx in the regulation of BBB permeability in physiological conditions and in diseases, the underlying mechanisms remained unclear. Microfluidic lab-on-a-chip (LOC) devices allow the study of BBB properties in dynamic conditions. We studied a BBB model, consisting of human endothelial cells derived from hematopoietic stem cells in co-culture with brain pericytes, in an LOC device to understand the role of fluid flow in the regulation of glycocalyx -related genes and surface charge. The MACE-seq gene expression profiling analysis showed differentially expressed core protein genes of the glycocalyx after fluid flow, as well as enriched pathways for the extracellular matrix molecules. We observed increased barrier properties, a higher intensity glycocalyx staining and a more negative surface charge of human brain-like endothelial cells (BLECs) in dynamic conditions. Our work is the first study to provide data on glycocalyx of BLECs in an LOC device under dynamic conditions and confirms the importance of fluid flow for BBB culture models.
\end{abstract}




\section{Introduction}

Due to the importance of the blood-brain barrier (BBB) in many systemic as well as central nervous system (CNS) diseases ${ }^{1}$ improved in vitro models are crucial as research tools for the biomedical community. In the last decade, several in vitro BBB models have been developed using cell culture inserts representing static conditions and more complex lab-on-a-chip (LOC) devices. ${ }^{2,3}$ Fluidic and microfluidic LOCs provide fluid flow and enable the study of BBB in a dynamic condition, ${ }^{4,5}$ in contrast to static cell culture inserts.

The morphology of the BBB, the structure of brain endothelial cells (EC) connected by tight intercellular junctions (TJ) and that of surrounding pericytes, astroglia endfeet, perivascular microglia and neuronal processes are well described. ${ }^{6}$ Recent advances in gene sequencing and single cell analysis led to better understanding of the molecular composition of cell populations of the brain including the cell types forming the BBB. ${ }^{7,8}$ More complete lists of influx and efflux transporters, receptors and transport pathways are available for the different types of BBB cells which participate in providing nutrients for the CNS and also act as protection systems. ${ }^{6,9}$ The BBB shields the CNS from toxins and pathogens but also participates in the pathomechanism of CNS injuries and neuroinflammation., ${ }^{1,6}$

In addition to physical defense mechanisms provided by TJs, and chemical protection by efflux pumps and BBB metabolic enzymes, the fourth major line of defense is the endothelial surface glycocalyx (ESG). Blood flow induces mechanical forces acting on the surface of ECs, which via mechanosensors, signalling pathways and gene expression, modulate endothelial morphology and function. ${ }^{10,11}$ ESG is a sugar-protein matrix like layer covering the EC surface mainly composed of proteoglycans, glycoproteins, and glycosaminoglycans. Its unique location, composition and structure serves as a negatively charged physical barrier on the surface of ECs. ${ }^{11}$ A recent in vivo study highlights the denser structure of glycocalyx of microvessel in the brain as compared to lung and heart, and associates it with brain EC protection as a defense component of the BBB. ${ }^{12}$ Indeed, the surface charge of brain ECs is more negative than that of other vascular ECs, which was related to a higher level of negatively charged phosphatidylserine and phosphatidylinositol in their cell membrane, ${ }^{13}$ in addition to the negative surface charge derived from the sulfate and sialic acid residues of the ESG. ${ }^{10,14}$ The structural complexity and the negative surface charge of the ESG at the BBB not only provide an extra barrier on the $\mathrm{EC}$, but also regulate the penetration of large molecules ${ }^{15}$ and charged drugs or vectors to the CNS. ${ }^{14,16}$ The protective role of ESG is well known in the cardiovascular system, and damage of this surface layer was demonstrated in diseases and pathologies like atherosclerosis, ischemia and inflammation. ${ }^{12,17}$ The characterization of ESG at the level of the BBB is incomplete and its importance is not fully understood.

Since LOCs provide more physiological conditions, in the present study we characterized a human BBB model composed of ECs derived from hematopoietic stem cells co-cultured with brain pericytes ${ }^{18}$ in our microfluidic and microelectronic device. ${ }^{5}$ Furthermore, our goal was to investigate the effect of fluid flow on gene expression of brain-like endothelial cells (BLECs) by in-depth massive analysis of cDNA ends 
sequencing (MACE-seq) with a focus on general endothelial, BBB-related and ESGrelated genes. To confirm the results endothelial morphology, lectin staining of ESG and surface charge measurements by laser Doppler velocimetry were performed. Our present work, together with our previous study revealing the importance of brain EC surface charge in the permeability of charged molecules, ${ }^{16}$ draws the attention to ESG as a flowregulated essential part of $\mathrm{BBB}$ models.

\section{Material and Methods}

\section{Materials}

All materials used in the study were purchased from Sigma-Aldrich, Hungary Ltd. (a subsidiary of Merck, Germany), unless otherwise indicated.

\section{Cell culture}

The in vitro $\mathrm{BBB}$ model, consisting of human endothelial cells in co-culture with bovine brain pericytes, was described by Cecchelli et al., 2014. The isolation of stem cells required the collection of human umbilical cord blood, which was approved by the Hospital ethical committee (Béthune Maternity Hospital, Béthune, France). Informed consent was obtained from the infants' parents. The protocol was approved by the French Ministry of Higher Education and Research (CODECOH Number DC2011-1321). The study was conducted according to World Medical Association Declaration of Helsinki. Human endothelial cells (hEC) were seeded in $0.2 \%$ gelatin coated culture dishes and kept in endothelial cell culture medium (ECM, Sciencell, USA) supplemented with $5 \%$ fetal bovine serum (FBS), $1 \%$ endothelial cell growth supplement (ECGS, Sciencell), and gentamycin $(50 \mu \mathrm{g} / \mathrm{ml})$. After reaching confluency, hECs were gently trypsinized and $80 \times 10^{3}$ cells seeded into the polyester membrane of the lab-on-a-chip (LOC) device (Figure 1(b)), coated with Matrigel (BD Biosciences, USA). The LOC was built as described in our previous publication, ${ }^{5}$ a brief protocol is provided in the Supplementary Methods. Bovine brain pericytes (PC) were cultured in $0.2 \%$ gelatin coated dishes in Dulbecco's modified Eagle's medium (DMEM, Life Technologies, Thermo Fisher Scientific, USA) supplemented with 20\% FBS, 1\% Glutamax (Life Technologies) and gentamicin $(50 \mu \mathrm{g} / \mathrm{ml})$. When cultures reached confluency, PCs were trypsinized and $25 \times 10^{3}$ cells were added to the bottom compartment of the LOC device coated with $0.2 \%$ gelatin (Figure 1(b)). During co-culture both compartments received endothelial medium. The LOC device with the cells was kept at $37^{\circ} \mathrm{C}$ in a humified atmosphere and $5 \% \mathrm{CO}_{2}$. For more details, see Supplementary Methods.

\section{Dynamic culture conditions in the LOC device}

To determine the importance of fluid flow on BLECs, the co-culture of hECs with PCs lasted for 6 days under static condition (supplementary Figure 1) then 24 hours under dynamic condition (Figure 1(c)), and compared with cells which were kept under static condition for 7 days (for details see Supplementary Methods). Cell growth was monitored by phase contrast microscopy (MotiCam 1080, MoticEurope, Barcelona, Spain), since the transparency of the gold electrodes in the LOC device enables the visualization of the entire cell monolayer. TEER was measured every day. Upon reaching the $6^{\text {th }}$ day, a constant circulation of culture medium was introduced by a peristaltic pump (Masterflex, 
Cole-Parmer, USA) at $1 \mathrm{ml} / \mathrm{min}$ flow rate $\left(0.4 \mathrm{dyne} / \mathrm{cm}^{2}\right)$ for 24 hours for the model in dynamic conditions. Co-cultures in static conditions were kept as shown in Supplementary Figure S1. Right after this 24-hour static and dynamic condition we performed barrier integrity studies on the human BBB model, did RNA extraction of BLECs, stained the glycocalyx and measured the surface charge of BLECs.

\section{Barrier integrity measurement: transendothelial electrical resistance and permeability}

Cells were kept in co-culture for 7 days and TEER values were recorded daily. The TEER was measured as described in our previous work ${ }^{5}$ : the LOC electrodes were connected to the $\mathrm{EVOM}^{2}$ voltohmmeter and the TEER values were registered (Figure 1(c)). To assess the barrier integrity small molecular weight marker lucifer yellow (LY, MW: $457 \mathrm{Da})^{18}$ and Evans blue dye bound to $1 \%$ bovine serum albumin (EBA, MW: $67.5 \mathrm{kDa}$ ) ${ }^{5}$ were used. Medium in the upper compartments of the LOC devices was replaced with $150 \mu \mathrm{l}$ of Ringer-Hepes solution containing LY $(5 \mu \mathrm{M})$ and EBA $(165 \mu \mathrm{g} / \mathrm{ml}$ dye bound to $1 \%$ albumin). In the bottom compartments $350 \mu 1$ of Ringer-Hepes solution was added. LOCs were incubated for 20, 40 and 60 minutes in a $\mathrm{CO}_{2}$ incubator at $37{ }^{\circ} \mathrm{C}$ on a horizontal shaker (150 rpm/min). Samples were collected from both compartments and fluorescent intensity measured by spectrofluorometer (Horiba Fluorolog 3, Japan). For details of the permeability assay and calculation of apparent permeability coefficients $\left(\mathrm{P}_{\mathrm{app}}\right)$, see Supplementary Methods.

\section{Immunohistochemistry}

Cells were fixed with ice cold methanol and acetone solution (1:1) for 2 minutes, washed twice with phosphate buffered saline (PBS) containing 1\% FBS and blocked with $3 \%$ BSA in PBS for 1 hour. ECs were incubated with primary antibodies for $\beta$-catenin and claudin-5 diluted in $3 \%$ BSA-PBS blocking buffer and incubated overnight at $4{ }^{\circ} \mathrm{C}$. Cells were washed in PBS and incubated with secondary antibody anti-rabbit IgG-CY3 and H33342 dye for 1 hour. The same protocol was used to stain brain PCs for $\alpha$-smooth muscle actin, NG2 and PDGFR- $\beta$. Alexa fluor 488 anti-mouse IgG, anti-rabbit IgG-CY3 were used as secondary antibodies. Samples were visualized by a Leica TCS SP5 confocal laser scanning microscope. For more details, see Supplementary Methods.

\section{Massive analysis of cDNA ends library preparation and RNA sequencing}

RNA isolation and RNA integrity analysis were performed as described in Supplementary Methods. Genome-wide gene expression profiling was performed using massive analysis of cDNA ends (MACE-seq) with RNA extracted from hECs co-cultured with PCs in static and dynamic conditions ( 3 and 5 biological replicates, respectively). A total of 8 libraries were constructed using the Rapid MACE-Seq kit (GenXPro GmbH, Frankfurt, Germany), according to the manufacturer's protocol. MACE-seq performs gene expression profiling by sequencing part of the 3' end of mRNA transcipts. While synthetizing one cDNA molecule from each mRNA transcript, MACE-seq can accurately quantify transcribed polyadenylated transcripts. For more details, see Supplementary Methods. 


\section{Bioinformatic analysis of MACE-seq data}

Approximately 62 million MACE-seq reads were obtained across all 8 libraries, and subsequently processed and analyzed bioinformatically. PCR-duplicates were identified using the TrueQuant technology and subsequently removed from raw data. The remaining reads were further poly(A)-trimmed and low-quality reads were discarded. In the following step, the clean reads were aligned to the human reference genome (hg38, http://genome.ucsc.edu/cgi-bin/hgTables) using bowtie2 mapping tool resulting in a dataset of 28,834 different genes. The gene count data was normalized to account for differences in library size and RNA composition bias by calculating the median of gene expression ratios using DESeq2 R/Bioconductor package. ${ }^{19}$ Testing for differential gene expression was also performed using the DESeq2 R/Bioconductor package. As a result, p-value and $\log 2$ (fold change) $(\log 2 \mathrm{FC})$ were obtained for each gene in the dataset. False discovery rate (FDR) analysis was estimated to account for multiple testing. Genes with a p-value $<0.05$ and $|\log 2 \mathrm{FC}|>1$ were considered to be differentially expressed. To perform functional profiling analysis g:Profiler was used to identify over-represented biochemical pathways from 3 databases (KEGG, Reactome and Gene Ontology) and to calculate the statistical significance of each pathway. GOplot was used to calculate the zscore from each over-represented pathway. ${ }^{20}$ The transcriptomic datasets generated and analyzed in this study are available in the Gene Expression Omnibus (GEO) repository. ${ }^{21}$ GEO accession number is GSE155671 and will also be available at the BBBHub (http://bbbhub.unibe.ch).

\section{Zeta potential measurements}

The zeta potential reflecting the surface charge of brain endothelial cells was measured by laser Doppler velocimetry using a Zetasizer Nano instrument (Malvern Instruments, UK) equipped with a He-Ne laser $(\lambda=632.8 \mathrm{~nm})$ as described previously. ${ }^{16}$ For more details, see Supplementary Methods.

\section{Staining of cell surface glycocalyx}

After 24-hour dynamic and static condition hECs in co-culture with PCs were washed with Ringer-Hepes buffer and fixed by $1 \%$ paraformaldehyde in PBS for 15 min at room temperature. Following fixation cells were washed with PBS twice. Labeling of sialic acid and $\mathrm{N}$-acetyl-D-glucosamine residues within the glycocalyx was done using wheat germ agglutinin lectin (WGA) conjugated with Alexa fluor 488 (W11261, Invitrogen) diluted at $5 \mu \mathrm{g} / \mathrm{ml}$ concentration in PBS and incubated for $10 \mathrm{~min}$ at room temperature. ${ }^{22}$ Pictures were taken with an Olympus FV1000 confocal microscope (Olympus, Japan) at random positions, at least 6 images for each membrane. For each condition three independent experiments were performed. Fluorescent images were analyzed for staining intensity using the FIJI (ImageJ) software.

\section{Statistics}

Data are represented as means $\pm \mathrm{SD}$. To test the statistical significance between different 
groups, data were analyzed with unpaired t-test or one-way ANOVA followed by Bonferroni post-test using the GraphPad Prism 5.0 Software (GraphPad Software, USA). Results were considered statistically significant at $\mathrm{p}$-values $<0.05$. Experiments were repeated at least twice and a minimum number of 3 biological parallels were used.

\section{Results}

\section{Human BBB model in the LOC device: effect of flow on barrier properties}

The human BBB model has been characterized and comparisons of ECs in monoculture vs. co-culture with brain pericytes were described in static culture conditions. ${ }^{18,23}$ Our first goal was to optimize and characterize this human BBB model in the LOC device under flow. The LOC has two fluid compartments, similarly to culture inserts: a porous PET membrane separates the top and bottom channels (Figure 1(a) and 1(b)). One of the biggest advantages of the LOC compared to the cell culture insert setup is the possibility of applying fluid flow to induce shear stress to mimic more physiological conditions for brain EC cultures. ${ }^{5}$ As in the case of cell culture inserts, ${ }^{18,23}$ ECs were added to the top compartment, and PCs were seeded to the bottom compartment (Figure 1(b)). During the first 6 days feeding was applied every 8 hours (Supplementary Figure 1), followed by a 24-hour dynamic condition (flow rate: $1 \mathrm{ml} / \mathrm{min} ; 0.4 \mathrm{dyne} / \mathrm{cm}^{2}$; Figure1(d)). For the static model 7 days of automatic feeding was used and no fluid flow was applied. The tightness of the barrier, which reflects the permissiveness of the monolayer for the passage of ions and molecules was characterized by measurement of TEER and permeability for LY and EBA. ${ }^{5}$ As shown in Figure 1(d) 24-hour fluid flow elevated the TEER significantly by $18 \%\left(361.8 \pm 166.3 \Omega \times \mathrm{cm}^{2}\right.$ to $\left.425.5 \pm 188.8 \Omega \times \mathrm{cm}^{2}\right)$. The paracellular permeability for LY was significantly decreased after fluid flow by $77 \%\left(27.2 \pm 9.7\right.$ to $\left.6.4 \pm 2.810^{-6} \mathrm{~cm} / \mathrm{s}\right)$ similarly to permeability for EBA, which was significantly decreased by $88 \%$ $\left(1.76 \pm 0.02\right.$ to $\left.0.12 \pm 0.0110^{-6} \mathrm{~cm} / \mathrm{s}\right)$ after dynamic condition (Figure $1(\mathrm{~d})$. The morphology of BLECs also changed after dynamic as compared to static condition. After flow a more elongated cell shape was visible (Figure 1(f)) than in cells under static condition. The change in cell shape in dynamic condition was also evident in pictures taken of immunostaining for tight junction protein claudin-5 and cytoplasmic adherens junction linker protein $\beta$-catenin (Figure $1(\mathrm{~g})$ ). Brain pericytes showed a uniform morphology and stained for $\alpha$-smooth muscle actin and NG2 throughout all experiments (Figure 1(g)). 
(a)

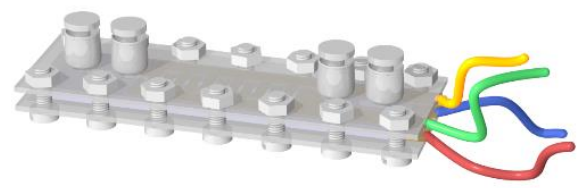

(c)

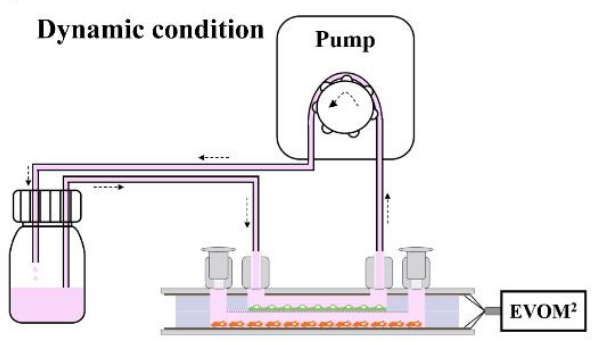

(f)
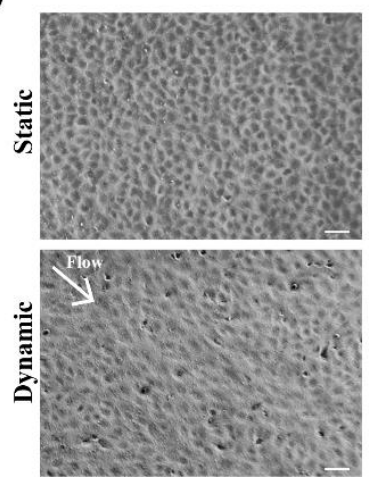

(b)

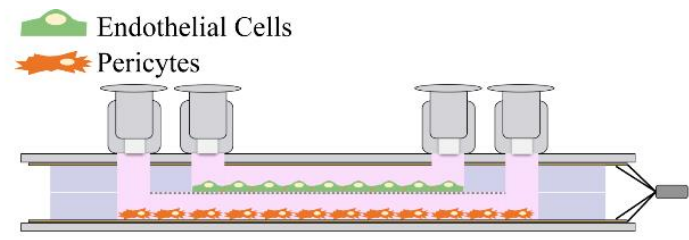

(d)

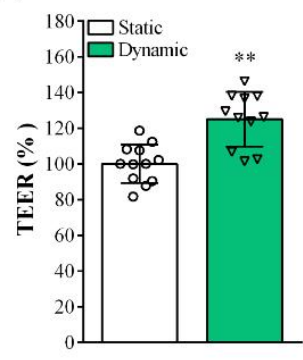

(e)

(g)
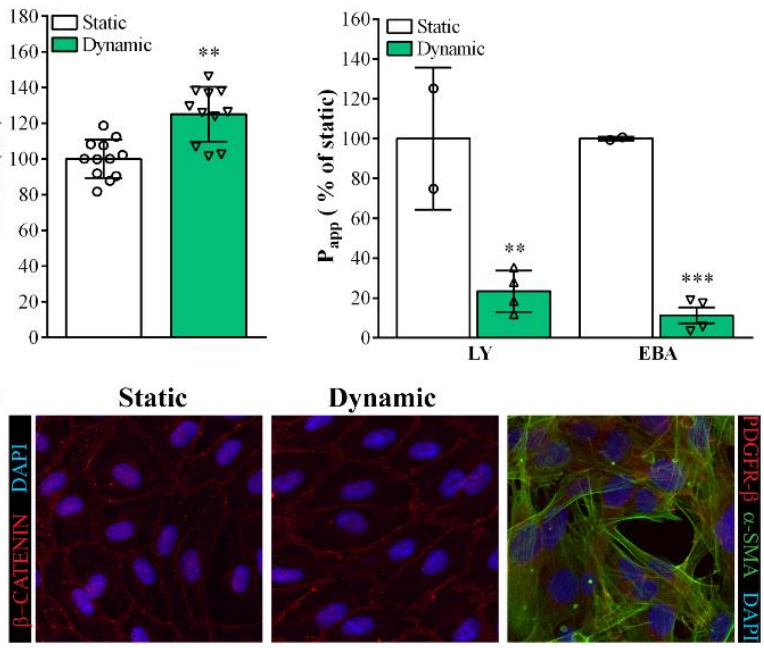

Dynamic
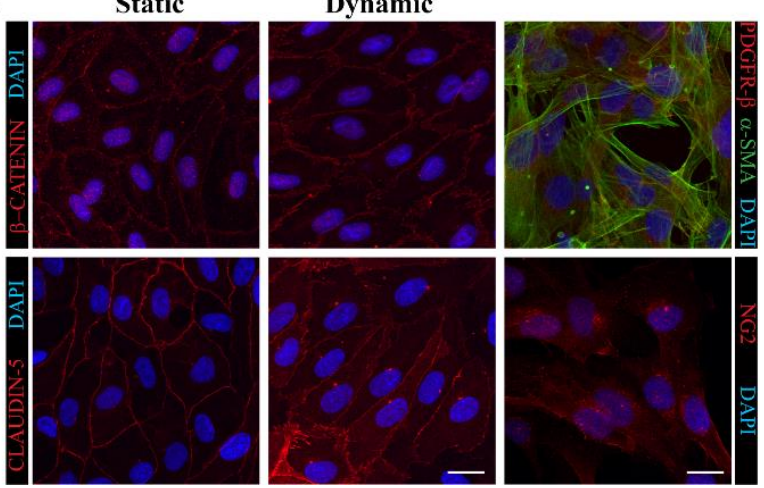

Figure 1. Characterization of the human BBB model cultured in the lab-on-a-chip (LOC). (a) Representative illustration of the device. The plastic slides carrying the gold electrodes to measure transendothelial electric resistance (TEER) are positioned at the top and bottom of the device, followed by the top and bottom channels made by PDMS and the cell culture membrane in the middle. The layers of the LOC were joined with screws. The female luer inlets were located on the top and provided easy access for both top and bottom channels. (b) Diagonal view of the LOC. Human brain endothelial cells were added to the top compartment, brain pericytes to the bottom. (c) Dynamic condition: the device was connected to a peristaltic pump and a reservoir containing cell culture medium. Fluid flow was applied at a speed of $1 \mathrm{ml} / \mathrm{min}$ for 24 hours. (d) TEER results were normalized to the values of the static condition which did not receive any fluid flow, values are presented as means $\pm \mathrm{SD}$, unpaired t-test, $* * \mathrm{p}<0.01, \mathrm{n}=12$. (e): Apparent permeability coefficient (Papp) of the human BBB model under static and dynamic conditions, for lucifer yellow (LY) and Evans-blue labelled albumin (EBA) marker molecules. Data is shown as the \% of the static condition and presented as means \pm SD (unpaired t-test, $* p<0.05, * * p<0.01, n=2-4$ ). (f) Phase contrast images of brain endothelial cells under static and dynamic conditions. Scale bar: $20 \mu \mathrm{m}$. (g) Endothelial cell morphology was characterized by immunostaining for claudin-5 and $\beta$-catenin junctional proteins. Brain pericytes were characterized by PDGF- $\beta$ receptor, $\alpha-$ smooth muscle actin ( $\alpha$-SMA) and NG2 followed by visualization with confocal microscopy. Scale bar: $20 \mu \mathrm{m}$.

Transcriptomic profile of the human BBB model: effect of flow on the global gene expression profile

To further characterize the effect of fluid flow on the human BBB co-culture model, we analyzed the transcriptomic gene expression profile of ECs using the MACE-seq. Gene expression profiling analysis was able to detect expression from 28,807 different genes 
(Supplementary Figure S3(a)). A total of 396 genes had a p-value lower than 0.05 and an $|\log 2 \mathrm{FC}|>1$, which were considered differentially expressed (Figure 2(b)). From all the expressed genes, $174(0.6 \%)$ and $222(0.8 \%)$ were up and down regulated, respectively (Figure 2(a)). Using more stringent thresholds of $|\log 2 \mathrm{FC}|>2$ or $<-2,67(0.2 \%)$ upregulated and $73(0.3 \%)$ downregulated genes were identified, respectively. Hierarchical clustering and principal component analysis (PCA) were used to assess relatedness between samples (supplementary Figure 3(a) and (b)). PCA and clustering analysis grouped the expression profiles from dynamic and static condition in two separate clusters. Many of the top 50 differentially expressed, up- or downregulated genes (Supplementary Table S1-S3) are related to cell adhesion, basal membrane composition, surface glycocalyx, enzymatic or transport processes at the BBB, which we discuss in the relevant sections below.

(a)

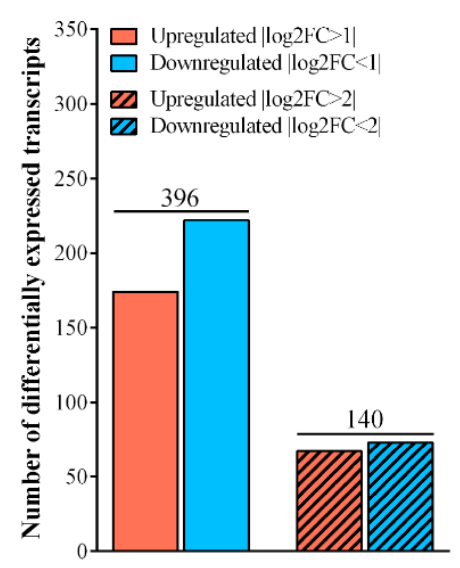

(b)

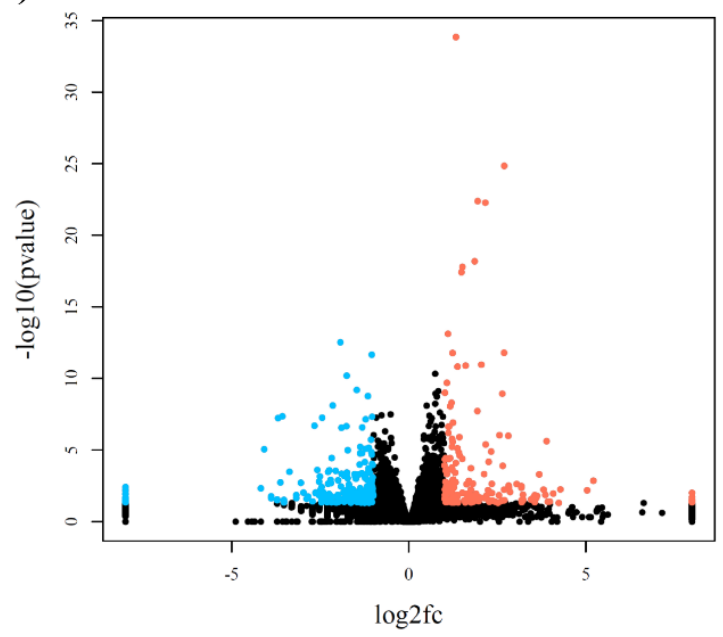

Figure 2. (a) Number of differentially expressed transcripts of human endothelial cells cocultured with brain pericytes under dynamic and static conditions. The total number of differentially expressed transcripts are shown on top of the bars. Testing for differential gene expression was performed using the DESeq2 R/Bioconductor package. ${ }^{19}$ (b) The volcano plot identifies the total changes in the data set. Black: no change, Blue: downregulated genes, Red: upregulated genes.

Transcriptomic gene expression profile of the human BBB model: effect of flow on endothelial cell markers

During the analysis of MACE data, we first wanted to verify the influence of fluid flow on the expression of general endothelial marker and other endothelial cell-related genes. Several basic endothelial marker genes were expressed in BLECs, including von Willebrand factor (VWF), vascular endothelial growth factor genes (VEGFA, B, C) and their receptors (VEGFR1-3), angiopoietins (ANGPT1 and 2), endothelial cell specific molecule 1 (ESM1) and endothelial nitric oxide synthase (NOS3), as expected. However, many of these genes were not changed by flow (Figure 3(a)). Among the endothelial genes 24-hour flow significantly upregulated endothelin 1 (EDN1), nitric oxide synthase interacting protein (NOSIP) and vascular endothelial growth factor receptor 1 (VEGFR1) (Figure 3(a)) and downregulated the lymphatic vessel endothelial marker gene LYVE1. 
A

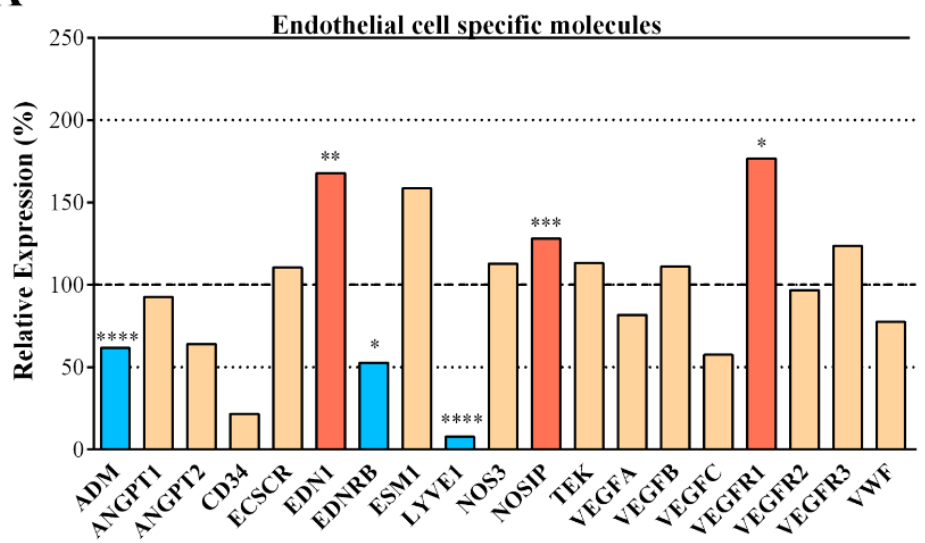

B

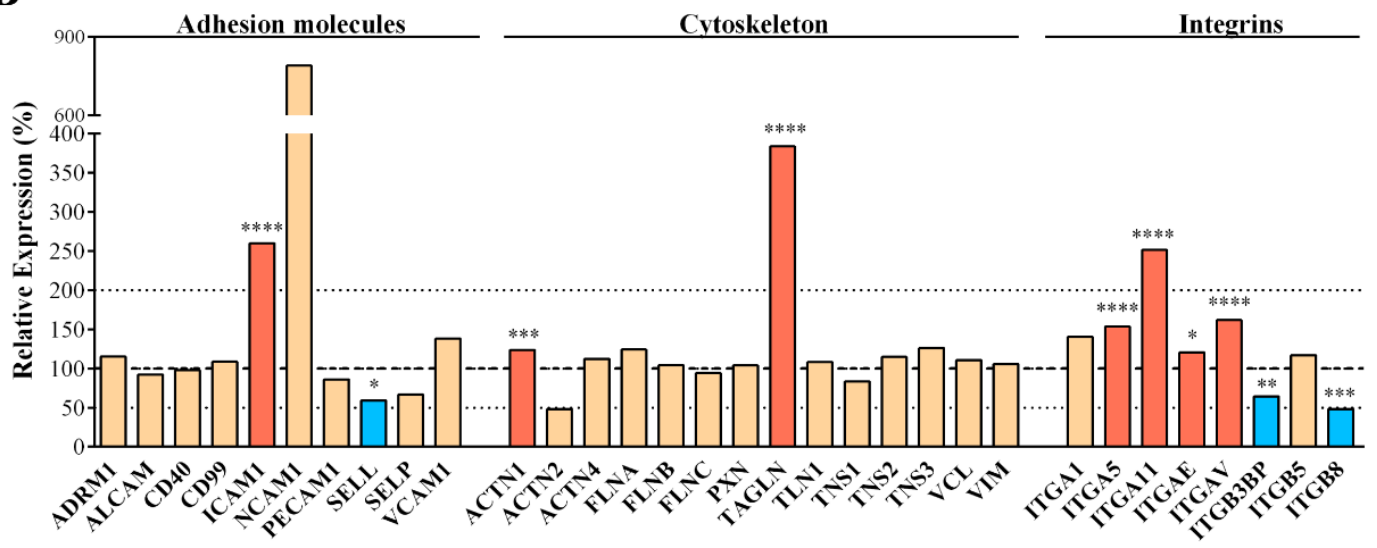

C

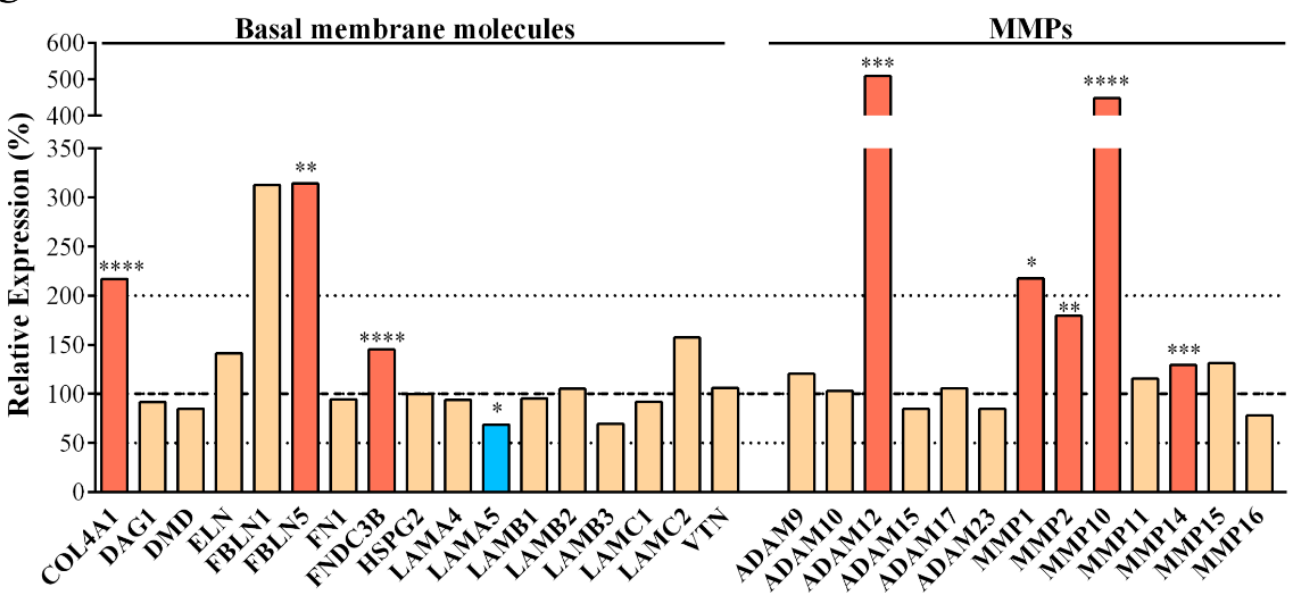

Figure 3. Transcriptomic gene expression profile of (a) Endothelial cell specific genes and primary cilia genes; (b): Endothelial cell adhesion molecule, cytoskeleton molecule and integrin genes; (c): Basal membrane molecule and matrix metalloproteinase (MMP) genes. Expression is shown as the relative expression (\%) of the genes present in human endothelial cells cocultured with brain pericytes in dynamic condition as compared to static condition. Testing for differential gene expression was performed using the DESeq2 R/Bioconductor package. ${ }^{19}$ Genes with a p-value $<0.05$ and less than $50 \%$ or more than $200 \%$ gene expression levels were considered to be differentially expressed. Red color labels upregulation and statistically significant expression changes, blue color shows downregulation and statistically significant expression change, cream color indicates no change in the gene expression $\left({ }^{*} \mathrm{p}<0.05,{ }^{*} \mathrm{p}<0.01\right.$, $* * * \mathrm{p}<0.001, * * * * \mathrm{p}<0.0001)$. 
Primary cilia are known mechanosensors of flow in endothelial cells. ${ }^{24}$ Genes of primary cilia proteins were expressed in the human BBB model, and polycystin (PDK) and tubulins (TUBA1A and B2A) were significantly overexpressed after flow (Figure 3(a)). In dynamic condition among the adhesion molecules (Figure 3(b)), the expression of intercellular adhesion molecule-1 gene (ICAM1) was significantly elevated. Other members of this group were not changed by flow, such as adhesion regulating molecule-1 (ADRM1), activated leukocyte cell adhesion molecule (ALCAM), CD99, and vascular cell adhesion molecule-1 (VCAM1), while L-selectin gene (SELL) got downregulated. Flow had no effect on endothelial cytoskeleton genes in the human BBB model, including actinins (ACTN), filamin (FLN), talin (TLN), tensin (TNS), vinculin (VCL) and vimentin (VIM), while significantly increased the expression of $\alpha$-actinin-1 (ACTN1) and the actin cross-linker transgelin (TAGLN) genes. Importantly, genes for several members of the integrin family, especially $\alpha$-subunits (ITGA5, ITGA11, ITGAE, ITGAV) were overexpressed after flow (Figure 3(b)), along with a number of brain endothelial basal membrane genes like collagen type IV (COL4A1), as well as fibulin 5 (FBLN5), FNDC3B and members of the matrix metallopeptidase family (MMP1, -2, -10, -14) (Figure 3(c)). From the members of the a disintegrin and metalloproteinase (ADAM) family expressed in the human BBB model only one gene, ADAM-12 was upregulated by flow. Several basal membrane genes were unchanged by flow, including dystrophin (DMD), elastin (ELN), perlecan or basement membrane-specific heparan sulfate proteoglycan core protein (HSPG2), laminins (LAM) and vitronectin (VTN). The significant upregulation of genes for cytoskeleton proteins, integrins and basal membrane molecules indicates pathways leading to better attachment of the cell layer at the abluminal side and demonstrates the importance of dynamic conditions for BBB models to better mimic physiological conditions in vitro.

\section{Transcriptomic gene expression profile of the human BBB model: effect of flow on BBB-related genes}

Three main junction groups participate in the formation of BBB: tight junctions (TJ), adherens junctions (AJ) and gap junctions (GJ). ${ }^{25}$ These intercellular connections enable brain endothelial cells to form a dynamic interface between the blood and CNS. ${ }^{6}$ Several TJ transmembrane or linker proteins were present at an unchanged level after the dynamic condition, including endothelial cell-selective adhesion molecule (ESAM), occludin (OCLN), claudin-12 (CLDN12), junctional adhesion molecule 3 (JAM3), MARVELD1 and -D2, zonula occludens protein-1 and -2 (TJP1 and TJP2) (Figure 4(a)). The gene expression level of JAM1, as well as that of CLDN1, -3, -5 and -7 were decreased after flow condition (Figure 4(a)). Among AJ proteins the gene expression level of vascular endothelial or VE-cadherin (CDH5), neuronal or N-cadherin (CDH2), nectin-2 and -3, $\alpha$ and $\beta$-catenins (CTNNA1 and CTNNAB1) remained unchanged, while the expression levels of E-cadherin (CDH1) and protocadherins-1 and -9 (PCDH1 and PCDH9) genes increased. Genes for gap junction proteins, known to be involved in intercellular 
communication and the regulation of TJs and AJs, connexin 43 (GJA1) and connexin 40 (GJA5) were significantly upregulated by dynamic condition (Figure 4(a)).

Active efflux pumps and drug metabolizing enzymes represent another line of defense at the level of BBB by providing protection against toxic chemical compounds. As shown in Figure 4(b) the gene expression level for many of the important ATP cassette binding $(\mathrm{ABC})$ and other transporters participating in drug and metabolite efflux was unchanged after flow condition: ABCB1 (P-glycoprotein, P-gp), ABCG2 (breast cancer resistance protein, BCRP), members of the ABCC family (ABCC1-6 or MRP1-6) and the excitatory amino acid transporter-3 belonging to the solute carrier (SLC) family (SLC1A1/EAAT3). Other transporters, like the lipid transporters ABCA3 and ABCA8, expressed in both peripheral and brain tissues, were significantly downregulated after the dynamic condition along with the organic anion-transporting polypeptide 1 (SLCO4A1/OATP1) and the organic cation transporter-2 (SLC22A5/OCTN2). The only drug efflux transporter which gene was upregulated by flow was SLC22A5 (OCTN1). The cytochrome (CYP) P450 enzymes, which participate in steroid and drug metabolism (so called drug metabolism phase I enzymes) and thus contribute to subsequent efflux of conjugated drugs at the level of $\mathrm{BBB}$, are expressed in different barrier culture models. ${ }^{26}$ Many members of the CYP family were expressed in the human BBB model and CYP1A1 and CYP1B1 genes were significantly overexpressed after flow (Figure 4(b)). Additionally, drug metabolism phase II enzymes of the BBB, epoxide hydrolase-1 (EPHX1) and glutathione S-transferase $\pi$ (GSTP1) were also upregulated by flow (Figure 4(b)).

SLCs including glucose, monocarboxylate, amino acid and peptide transporters were expressed either with an unchanged level or were significantly overexpressed after flow in BLECs, except for SLC7A5/LAT1, which was downregulated (Supplementary Figure S4(a)). Among ion transporters and channels expressed at the $\mathrm{BBB},{ }^{1}$ two ion transporter genes were upregulated, while potassium channel genes were downregulated by flow condition (Supplementary Figure S4(b)). The gene expression of many important BBB receptor genes was unchanged, except LRP3 and LRP5 which were increased and LDLRAD3, very low density lipoprotein receptor (VLDLR) and caveolin-1 (CAV1) which were decreased (Supplementary Figure S4(b)). 
(a)

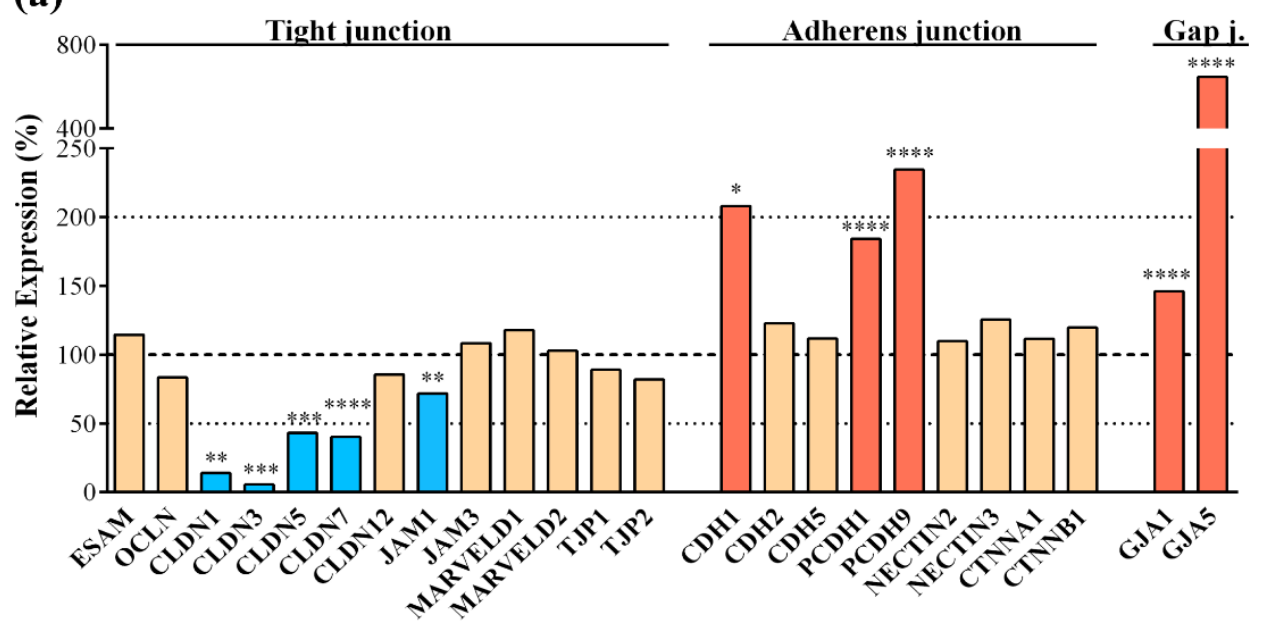

(b)

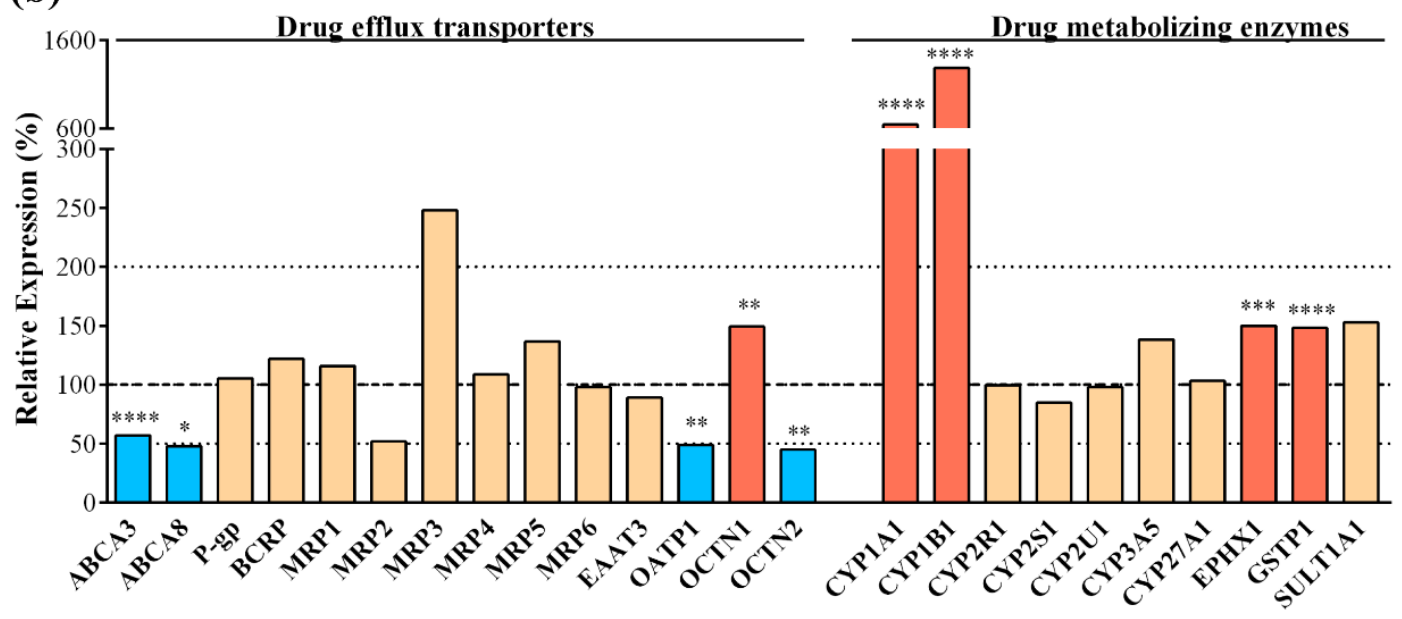

Figure 4. Transcriptomic gene expression profile of (a) tight, adherens and gap junction protein genes; (b) drug efflux transporter and drug metabolizing enzyme genes. Expression is shown as the relative expression (\%) of the genes present in human endothelial cells co-cultured with brain pericytes in dynamic condition as compared to static condition. Testing for differential gene expression was performed using the DESeq2 R/Bioconductor package. ${ }^{19}$ Genes with a p-value $<0.05$ and less than $50 \%$ or more than $200 \%$ gene expression levels were considered to be differentially expressed. Red color labels upregulation and statistically significant expression changes, blue color shows downregulation and statistically significant expression change, cream color indicates no change in the gene expression $(* \mathrm{p}<0.05, * * \mathrm{p}<0.01, * * * \mathrm{p}<0.001$, $* * * * \mathrm{p}<0.0001)$.

\section{Effect of flow on the human BBB model: endothelial surface charge and glycocalyx}

The endothelial surface glycocalyx (ESG) plays an important role in the mechano-sensing and transduction functions of endothelial cells, which are essential to maintain vascular integrity and homeostasis. ${ }^{10}$ ESG is a rich layer of carbohydrates connected through proteoglycans and glycoproteins to the surface of ECs (Figure 5(a) and (b)). ${ }^{27}$ Most of the in vitro $\mathrm{BBB}$ models based on cell culture inserts lack fluid flow, therefore represent a static environment. While the importance of the ESG and extracellular matrix are in general acknowledged as elements of the defence system of the BBB, this is an underresearched area. This is the reason why we aimed to investigate the transcriptomic 
gene expression changes of the surface glycocalyx and the extracellular matrix components after static and dynamic conditions of hECs co-cultured with PCs in our LOC. As shown in Figure 5(c), glycocalyx core proteins, like decorin (DCN), glypican-1 (GPC1), syndecan-2 (SDC2) and versican (VCAN) genes were significantly upregulated in the dynamic condition. Other ESG core protein genes like biglycan (BGN), CD44, and other syndecans (SDC1, SDC3, SDC4) were also present, but their expression levels were not changed by flow. Four types of galectins that bind specifically to $\beta$-galactoside sugars within the glycocalyx were expressed in BLECs (GAL1, GAL3, GAL8 and GAL9), of which the gene of galectin-3 (GAL3) was decreased by flow (Figure 5(c)). The human BBB model expressed a large number of enzymes which participate in the synthesis and remodeling of the ESG (Figure 5(c)). The genes of four enzymes, the carbohydrate sulfotransferase-1 (CHST1), heparanase (HPSE), hyaluronidase-2 (HYAL2) and the heparan sulfate 6-O-endosulfatase SULF2, which selectively removes 6-O-sulfate groups from heparan sulfate, were found to be upregulated by flow, while the expression of only one enzyme, $\beta$-1,4-galactosyltransferase-5 (B4GALT5) decreased. The expression changes in the ESG core proteins and galectins were caused by flow, since the effect of co-culture with PCs in static conditions did not induce such changes (Supplementary Figure 5(a)).

Brain EC glycocalyx is one of the thickest within the vasculature ${ }^{12}$ and also cultured brain ECs have highly negative surface charge. ${ }^{16}$ The main sources of this negative charge are the lipid head groups of the plasma membrane and the ESG, composed of highly negatively charged polysaccharide chains. Since ESG related genes were upregulated by flow, zeta potential measurement was performed to determine if the changes at gene expression influence the absolute value of the surface charge of BLECs. We measured a significant decrease in surface charge of BLECs (Figure 5(d)) in dynamic condition $(-12.4 \pm 1.4 \mathrm{mV})$ compared to static condition $(-11.0 \pm 1.0 \mathrm{mV})$. We also compared the effect of co-culture with PCs in static conditions using cell culture inserts, and found that the negative surface charge of BLECs in the co-culture model decreased $(-11.7 \pm 1.2 \mathrm{mV})$ compared to the monoculture $(-10.6 \pm 1.4 \mathrm{mV})$ (Supplementary Figure $5(\mathrm{~b}))$, indicating the importance of both flow and co-culture in the negative surface charge of brain ECs. 
(a)

(b)

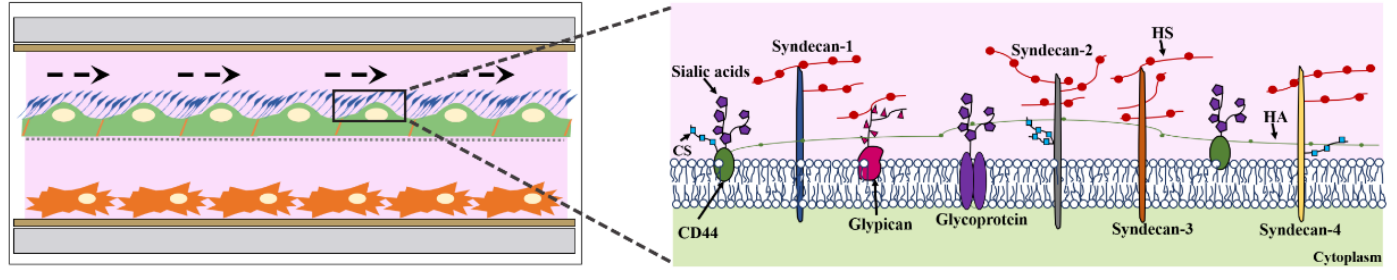

(c)

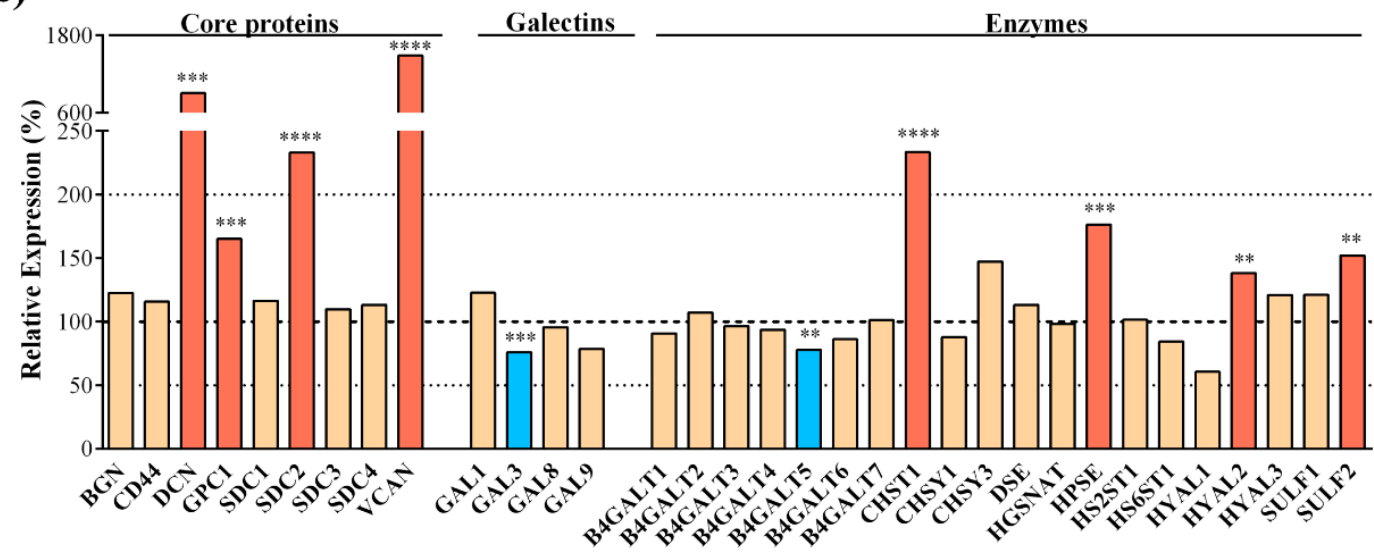

(d)

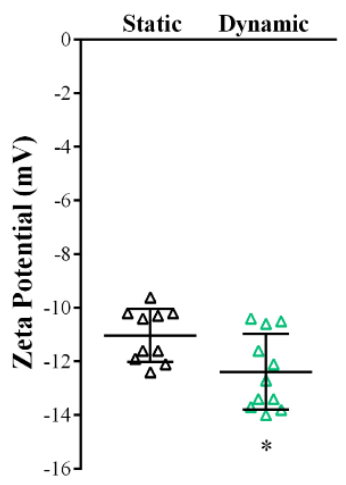

(e)

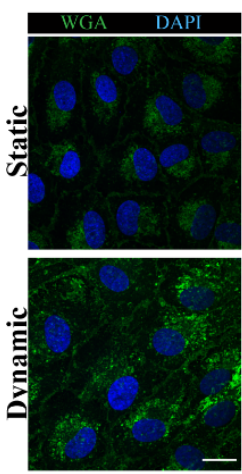

(f)

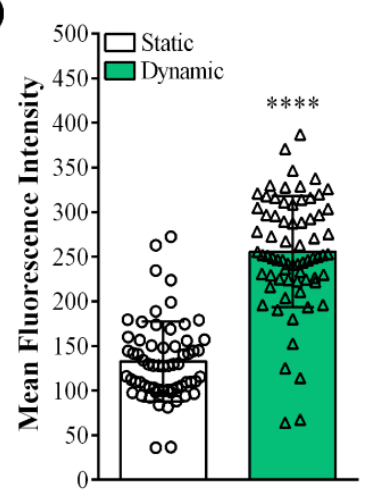

Figure 5. (a) Illustration showing the effect of fluid flow on the endothelial surface glycocalyx (ESG). (b) Drawing representing ESG core proteins, glycoproteins and glucosaminoglycans. HA: hyaluronic acid, HS: heparan sulfate, CS: chondroitin sulfate. (c) Transcriptomic gene expression profile of ESG-related genes. Expression is shown as the relative expression (\%) of the genes present in human endothelial cells co-cultured with brain pericytes in dynamic condition as compared to static condition. Testing for differential gene expression was performed using the DESeq2 R/Bioconductor package. ${ }^{19}$ Genes with a p-value $<0.05$ and less than $50 \%$ or more than $200 \%$ gene expression levels were considered to be differentially expressed. Red color labels upregulation and statistically significant expression changes, blue color shows downregulation and statistically significant expression change, cream color indicates no change in the gene expression $(* \mathrm{p}<0.05, * * \mathrm{p}<0.01, * * * \mathrm{p}<0.001$, $* * * \mathrm{p}<0.0001)$. (d) Zeta potential measured by laser Doppler velocimetry (means $\pm \mathrm{SD}, \mathrm{n}=10$; unpaired t-test, $* \mathrm{p}<0.05$ compared to static condition). (e) and (f) Staining of ESG on brain endothelial cells with fluorescently labeled wheat germ agglutinin (WGA) lectin. WGA binds to the sialic acid residues therefore the fluorescent intensity of the images shows the thickness and density of the glycocalyx components. Scale bar: $20 \mu \mathrm{m}$. Image analysis values are presented as means $\pm S D, n=72$; unpaired t-test, $* * * * \mathrm{p}<0.0001$ compared to static condition. 
The more negative surface was related to a denser ESG as confirmed by the fluorescently labelled WGA lectin staining: a $90 \%$ increase in the fluorescence intensity was observed in the confocal images after 24-hour flow (Figure 5(e) and (f)). A 30\% increase in WGA lectin staining was also observed in hECs in co-culture with PCs as compared to monocultures in static conditions (Supplementary Figure 5(c) and (d)).

The effect of flow on the ESG was corroborated by the gene enrichment profiles (Figure 6). We found that the most significantly upregulated pathways after the introduction of flow conditions were the extracellular matrix and structure pathways and ESG related pathways.

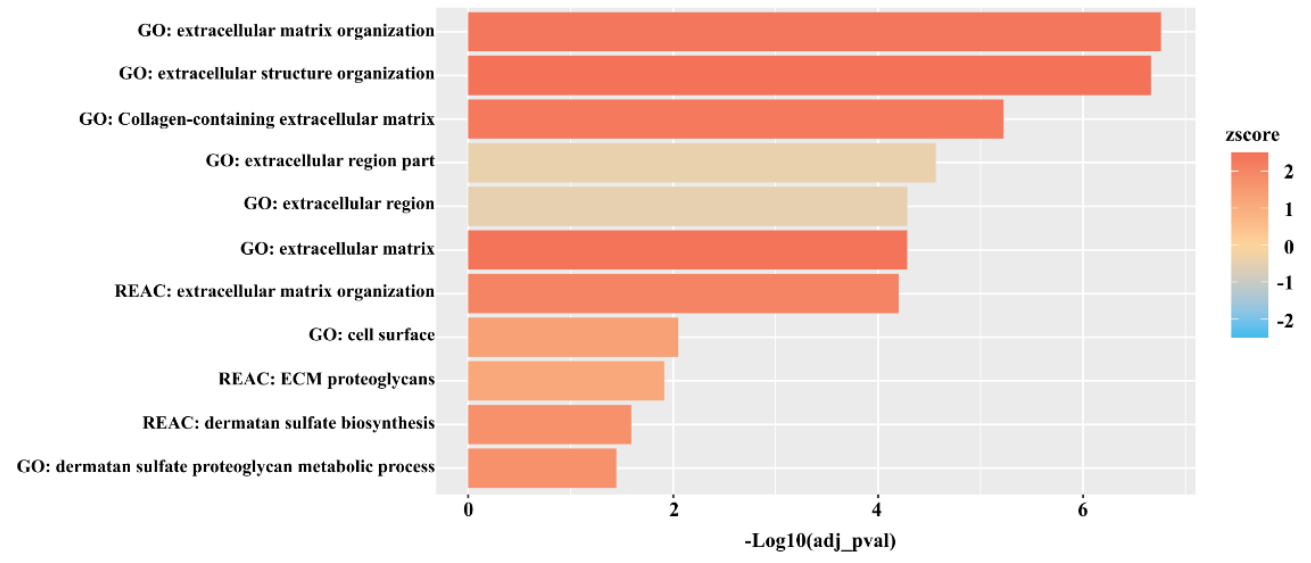

Figure 6. Functional profiling analysis of extracellular matrix-related pathways in static versus dynamic condition. The $\mathrm{x}$-axis represents the statistical significance calculated using $\mathrm{g}$ :Profiler while the zscore represents the tendency of the regulation of these pathways calculated using GOplot.

\section{Discussion}

RNA sequencing analysis provided new data on mouse brain EC transcriptomics ${ }^{7}$ and on zonation of ECs in mouse brain vasculature. ${ }^{8}$ Culture models of the BBB in static condition have also been characterized at the transcriptomic level ${ }^{26,28}$ including the BLEC model we use in the present study. ${ }^{23} \mathrm{We}$ found one study on the effect of fluid flow on the transcriptome of a human cell-based BBB model, ${ }^{4}$ but no study analyzed transcriptomic changes of a human BBB model in an LOC-based system in dynamic condition yet.

The BBB is composed of brain ECs that have strong interaction with the neighboring astroglia endfeet and pericytes. Brain pericytes share a common basal membrane with the ECs and they have an important role in the development, maintenance, and regulation of BBB functions. ${ }^{1,29}$ Co-culture of brain ECs with PCs is known to elevate the tightness of the paracellular barrier and increase the BBB properties. ${ }^{18,30,31}$ The human BBB model used in our study, in which ECs are derived from hematopoietic stem cells and co-cultured with bovine brain pericytes, is a well characterized in vitro model. ${ }^{18,23,32}$ There is only one recent study which describes the adaptation of this BBB model to the use of short-term (4 and 30 minutes) fluid flow with the goal to study immune cell transmigration. ${ }^{32}$ However, no longer term (24-hour) fluid flow and its effects on this BBB model have been investigated until now. It is important 
to note, that the shear stress applied in our study is lower than what is calculated for brain capillaries in vivo. Nevertheless, the characterization of a human co-culture BBB model under static and dynamic conditions in an LOC device and the global transcriptomic gene expression analysis may provide valuable data to further improve BBB LOC models.

First, we measured the barrier properties of the hEC and bovine PC co-culture model in the LOC device. In static conditions in the device similar TEER values were obtained for this human BBB model as for several types of in vitro co-culture models, including primary cell based ones. ${ }^{26}$ After introducing fluid flow, TEER values significantly increased and permeability of the brain EC monolayers significantly decreased for both LY and EBA markers. Similar changes were found by previous studies using human BBB culture models in LOC devices. ${ }^{4,5}$ The permeability values obtained for the marker molecule LY in dynamic conditions in the LOC device was lower than those in previous studies using culture inserts representing static conditions. ${ }^{18,32}$ In contrast to the dynamic in vitro system using hollow fiber cartridges ${ }^{4}$ our LOC device ${ }^{5}$ allowed the morphological observation of hECs, which showed similar immunostaining of junctional proteins as in the culture insert models. ${ }^{18,32}$ Fluid flow changed cell shape to be more elongated and also realigned the cells in the direction of flow, in accordance with a previous study on bovine brain endothelial cells. ${ }^{33}$ These observations prove, that the LOC device is functional and show the importance of fluid flow in barrier integrity regulation of in vitro human BBB models. ${ }^{4,5}$

Blood flow in capillaries and the resulting shear force are important physiological regulators of EC functions in the periphery ${ }^{10}$ and in the brain. ${ }^{1}$ Many in vitro BBB models are based on culture inserts, therefore lack fluid flow. ${ }^{26}$ Hollow fiber cartridges ${ }^{4}$ and microfluidic LOC devices ${ }^{3}$ allow the study of fluid flow on BBB models.

Flow-mediated regulation of endothelial genes has been studied on vascular ECs for a long time. Upregulation of genes TGF- $\beta$, EDN1/ET-1, CCL2/MCP-1 and ICAM-1 has been described previously ${ }^{34}$ and we confirmed these data in the present study. The observed changes in our BBB model are complex: while expression level of the vasoconstrictor EDN-1 gene was increased, the level of one of its receptor gene, EDNRB, was decreased, and the vasodilating factor NOSIP, which interacts with NOS3, was found to be significantly upregulated. VEGFR1, upregulated by flow in our model, mediates endothelial cytoprotection via serine/threonine-specific protein kinase AKT/protein kinase B. ${ }^{35}$ LYVE1, a marker for peripheral $\mathrm{ECs}^{8}$ was differentially downregulated by flow in BLECs. Primary cilia are mostly described as mechanosensors and their presence and importance in vascular ECs is described, ${ }^{24}$ but the expression of genes related to primary cilia in brain ECs is not known. In our study we identified a dozen primary cilia genes from which three, PKD1L1, TUBA1A and TUBB2A from the tubulin family were increased by flow condition. Among EC surface adhesion molecules flow elevated the expression of ICAM1 gene, as described in the case of vascular ECs ${ }^{34}$ and a human BBB model $^{4}$ which can be important for immune cell transmigration studies. ${ }^{32}$ The expression of L-selectin gene SELL, which is present in some populations of peripheral EC but not in cerebral endothelium ${ }^{8}$ was decreased on BLECs by flow.

Endothelial cells respond to fluid flow by changing their morphology to a more elongated shape and align with the flow direction. ${ }^{11}$ Our morphological findings on the 
human BBB model in the LOC device are in accordance with these observations, and further supported by the upregulation of cytoskeletal genes ACTN1, known to interact with NOS3, and TAGLN, crosslinking actin filaments and participating in cytoskeletal reorganization. Flow is also known to increase the adhesion of ECs to the basal membrane via integrins, which interact with collagen, laminin, and fibronectin. ${ }^{27} \mathrm{We}$ found that several integrin- $\alpha$ subunit genes (ITGA5, ITGA11, ITGAE, ITGAV) were significantly increased in dynamic conditions, while integrin- $\beta$ subunits were unchanged or downregulated. In a human EC and astrocyte co-culture model an increase in the gene expression for both $\alpha$ and $\beta$ integrin subunits was observed after flow, ${ }^{4}$ which may indicate a special role for astrocytes in the induction of these genes. In our study the differentially expressed basal membrane genes COL4A1, FBLN5 and the fibronectin related FNDC3B together with integrins may indicate a stronger attachment of the cells in dynamic condition. MMPs are important in different physiological and pathological processes at the BBB. In cerebral ischemia MMPs participate in both the vascular injury and the repair phase during angiogenesis and reestablishment of blood flow. ${ }^{36}$ In our study several MMPs were differentially expressed, and this upregulation may be related with basal membrane remodelling induced by flow.

The paracellular tightness of the BBB is controlled by transmembrane TJ proteins. We found the downregulation of epithelial claudins CLDN1, CLDN3, CLDN7 by flow. These claudins were also expressed at a low level in BBB culture models ${ }^{26}$ and in isolated brain ECs. ${ }^{7,8}$ Flow did not change the expression level of important TJ genes ESAM, OCLDN, JAMs, MARVELDs and linkers TJPs. The expression level of claudin-5 gene, considered as the most important claudin in brain ECs was decreased by flow in our coculture model with PCs, which was not observed in the astrocyte co-culture model. ${ }^{4}$ In contrast, the genes of adherens junction proteins were either unchanged or upregulated together with gap junction genes. These, together with the unchanged level of several TJ genes and increased level of basal membrane protein and integrin gene expression might explain that we observed an increased barrier integrity of the BBB model by functional measurements, namely TEER and permeability for marker molecules.

The chemical protection of the CNS is maintained by active efflux pumps, mainly $\mathrm{ABC}$ transporters, the gene expression level of which was mostly unchanged in dynamic condition. Enzymes participating in drug metabolism were more sensitive to the effect of flow, and their level was unchanged or upregulated like in the case of phase I enzymes CYP1A1 and CYP1B1, and phase II enzymes EPHX1 and GSTP1. The upregulation of P450 enzymes in a human BBB model by fluid flow was also described. ${ }^{4}$ The increased gene expression level of phase II enzymes EPHX1 and GSTP1 in brain ECs was also observed by co-culture with PCs. ${ }^{23}$

SLC transporters are key for the proper transport of nutrients to the CNS. ${ }^{9}$ The expression level of SLC transporters was either unchanged or in many cases increased in dynamic conditions. In addition to nutrients, the BBB regulates the transport of ions by SLCs. On the human BBB model flow increased the gene expression of anion exchanger AE2 and the $\mathrm{K}^{+}-\mathrm{Cl}^{-}$cotransporter (KCC1). While the level of voltage dependent $\mathrm{Ca}^{2+}$ (CACN family) and anion (VDAC) channels was unchanged by flow, several $\mathrm{K}^{+}$channels were found downregulated, which were also expressed at a very low level in isolated brain 
capillary ECs. ${ }^{8}$ In the human BBB co-culture model with astrocytes an upregulation of $\mathrm{Ca}^{2+}$ and $\mathrm{K}^{+}$channels was observed in dynamic conditions ${ }^{4}$ indicating an important role for the co-culture conditions.

Many important proteins and peptides, like insulin and holotransferrin, cross the BBB by receptor-mediated pathway. ${ }^{1}$ Flow did not change the expression level of many of these receptors. One of the exception is the gene of LRP5, a canonical WNT pathway signaling co-receptor, which was increased. Importantly, LRP5 participates in barrier genesis and BBB maturation. ${ }^{1}$ Flow also downregulated in the human BBB model the expression level of caveolin-1 gene. Since isolated brain ECs express much less CAV1 than peripheral (lung) ECs, ${ }^{8}$ these changes may point to barrier maturation in the present model.

While the study of Cucullo et al. described transcriptomic changes in BBB-related genes induced by flow on a human BBB model, ${ }^{4}$ no data are available on the gene expression of mechano-sensing and luminal glycocalyx components. Continuous blood flow regulates the composition of ESG, the dynamic equilibrium of glycoproteins, proteoglycans, glycosaminoglycans and the associated plasma proteins. ${ }^{27} \mathrm{ESG}$ is not only important as an element of the physical barrier ${ }^{15}$ with its highly negative charge but also control the stability of endothelial cells. We observed the differential upregulation of major glycocalyx core protein genes DCN, SDC2 and VCAN, as well as an increase in GPC1 expression, which act as mechano-sensors and also link the ESG to the cytoskeleton, therefore actively participate in flow induced morphological changes in ECs. ${ }^{10}$ The increased gene expression level of glycocalyx-related enzymes heparanase and hyaluronidase-2, as well as carbohydrate sulfotransferase- 1 and the heparan sulfate 6-O-endosulfatase SULF2 adding and removing sulfate groups, which are important for the overall negative charge of the glycocalyx, may indicate active remodeling of the ESG in dynamic condition. Direct measurement of the surface charge of the ECs by a laser Doppler velocimetry confirmed that cells became more negatively charged. These data together with increased WGA lectin staining support that the ESG of the human BBB model became more robust. These observations are further corroborated that the three most enriched pathways in the human BBB model after flow were related to extracellular matrix organization, extracellular matrix structure organization and collagen-containing extracellular matrix. In addition, several other pathways related to cell surface, extracellular matrix proteoglycan and dermatan sulfate biosynthesis and metabolism were also increased.

In conclusion, flow increased barrier properties, induced several key general endothelial and BBB-related genes on BLECs in the LOC device. In addition, flow not only upregulated extracellular matrix and glycocalyx-related genes and pathways, but made the brain endothelial cell surface more negatively charged and more rich in lectin binding sites. These results strongly argue for the inclusion of flow in BBB models and draw the attention to the importance of the endothelial surface glycocalyx as an element of the BBB. This human model can be used as a tool to study the role of cell surface glycocalyx in BBB physiology and pathology. 


\section{Acknowledgements}

We thank the BtRAIN Marie Sklodowska-Curie Innovative Training Network and its coordinator Prof. Britta Engelhardt for the inspiring meetings and networking, and the support of the Dr. Rollin D. Hotchkiss Foundation.

\section{Funding}

This work was supported by National Research, Development and Innovation Office, Hungary [grant number: OTKA K-108697, NNE 129617 as part of the M-Era.NET2 nanoPD project. ARSM and MH were supported by the European Training Network H2020- MSCA-ITN-2015 [Grant number 675619]. FRW is currently supported by the National Research, Development and Innovation Office, Hungary [grant number OTKA PD-128480], by the János Bolyai Research Fellowship of the Hungarian Academy of Sciences, and was supported during the work by the New National Excellence Program Bolyai+ fellowship (UNKP-19-4-SZTE-42) of the Ministry for Innovation and Technology, Hungary.

\section{Author contribution statement}

Conceptualization, ARSM, FRW, MD; Methodology, ARSM, FRW, RF, AK; Formal analysis, ARSM, RF; Investigation, ARSM, FRW, RF, MH, AK; Data curation, ARSM, FRW, RF; Writing - original draft preparation, ARSM, FRW, MD; Writing review and editing, ARSM, FRW, RF, AK, MH, MC, PW, FG, AD, MD; Supervision, FRW, AD, $\mathrm{PW}, \mathrm{MC}$ and MD; Funding acquisition, $\mathrm{AD}$ and $\mathrm{MD}$.

\section{Disclosure/conflict of interest}

The authors declare that they have no conflicts of interest with the contents of this article. 


\section{References}

1. Sweeney MD, Zhao Z, Montagne A, et al. Blood-Brain Barrier: From Physiology to Disease and Back. Physiol Rev 2019;99(1):21-78.

2. Helms HC, Abbott NJ, Burek M, et al. In vitro models of the blood-brain barrier: An overview of commonly used brain endothelial cell culture models and guidelines for their use. J Cereb Blood Flow Metab 2016; 36(5):862-890.

3. Raimondi I, Izzo L, Tunesi M, et al. Organ-On-A-Chip in vitro Models of the Brain and the Blood-Brain Barrier and Their Value to Study the Microbiota-Gut-Brain Axis in Neurodegeneration. Front Bioeng Biotechnol 2020; 7:435.

4. Cucullo L, Hossain M, Puvenna V, et al. The role of shear stress in Blood-Brain Barrier endothelial physiology. BMC Neurosci 2011; 12:40.

5. Walter FR, Valkai S, Kincses A, et al. A versatile lab-on-a-chip tool for modeling biological barriers. Sensors and Actuators B: Chemical 2016, 222: 1209-1219.

6. Abbott NJ, Patabendige AA, Dolman DE, et al. Structure and function of the bloodbrain barrier. Neurobiol Dis 2010;37(1):13-25.

7. Daneman R, Zhou L, Agalliu D, et al. The mouse blood-brain barrier transcriptome: a new resource for understanding the development and function of brain endothelial cells. PLoS One 2010; 5(10):e13741.

8. Vanlandewijck M, He L, Mäe MA, et al. A molecular atlas of cell types and zonation in the brain vasculature. Nature 2018;554(7693):475-480.

9. Campos-Bedolla P, Walter FR, Veszelka S, et al. Role of the blood-brain barrier in the nutrition of the central nervous system. Arch Med Res 2014;45(8):610-638.

10. Fu BM and Tarbell JM. Mechano-sensing and transduction by endothelial surface glycocalyx: composition, structure, and function. Wiley Interdiscip Rev Syst Biol Med 2013;5(3):381-390.

11. Zeng Y, Zhang XF, Fu BM, et al. The Role of Endothelial Surface Glycocalyx in Mechanosensing and Transduction. Adv Exp Med Biol 2018; 1097:1-27.

12. Ando Y, Okada H, Takemura G, et al. Brain-Specific Ultrastructure of Capillary Endothelial Glycocalyx and Its Possible Contribution for Blood Brain Barrier. Sci Rep 2018; 8(1):17523.

13. Ribeiro MM, Domingues MM, Freire JM, et al. Translocating the blood-brain barrier using electrostatics. Front Cell Neurosci 2012; 6:44.

14. Hervé F, Ghinea N and Scherrmann JM. CNS delivery via adsorptive transcytosis. AAPS J 2008; 10(3):455-472.

15. Kutuzov N, Flyvbjerg $\mathrm{H}$ and Lauritzen M. Contributions of the glycocalyx, endothelium, and extravascular compartment to the blood-brain barrier. Proc Natl Acad Sci USA 2018;115(40):E9429-E9438.

16. Santa-Maria AR, Walter FR, Valkai S, et al. Lidocaine turns the surface charge of biological membranes more positive and changes the permeability of blood-brain barrier culture models. Biochim Biophys Acta Biomembr 2019;1861(9):1579-1591.

17. van den Berg BM, Nieuwdorp M, Stroes ES, et al. Glycocalyx and endothelial (dys) function: from mice to men. Pharmacol Rep 2006; 58 Suppl:75-80.

18. Cecchelli R, Aday S, Sevin E, et al. A stable and reproducible human blood-brain barrier model derived from hematopoietic stem cells. PLoS One 2014;9(6):e99733.

19. Love MI, Huber W and Anders S. Moderated estimation of fold change and dispersion for RNA-seq data with DESeq2. Genome Biol 2014;15(12):550. 
20. Walter W, Sánchez-Cabo F and Ricote M. GOplot: an R package for visually combining expression data with functional analysis. Bioinformatics 2015;31(17):2912-2914.

21. Edgar R, Domrachev $M$ and Lash AE. Gene Expression Omnibus: NCBI gene expression and hybridization array data repository. Nucleic Acids Res 2002; 30(1):207-210.

22. Betteridge KB, Arkill KP, Neal CR, et al. Sialic acids regulate microvessel permeability, revealed by novel in vivo studies of endothelial glycocalyx structure and function. $J$ Physiol 2017;595(15):5015-5035.

23. Heymans M, Figueiredo R, Dehouck L, et al. Contribution of brain pericytes in bloodbrain barrier formation and maintenance: a transcriptomic study of cocultured human endothelial cells derived from hematopoietic stem cells. Fluids Barriers CNS 2020;17(1):48.

24. Luu VZ, Chowdhury B, Al-Omran M, et al. Role of endothelial primary cilia as fluid mechanosensors on vascular health. Atherosclerosis 2018; 275:196-204.

25. De Bock M, Vandenbroucke RE, Decrock E, et al. A new angle on blood-CNS interfaces: a role for connexins? FEBS Lett 2014; 588(8):1259-1270.

26. Veszelka S, Tóth A, Walter FR, et al. Comparison of a Rat Primary Cell-Based BloodBrain Barrier Model with Epithelial and Brain Endothelial Cell Lines: Gene Expression and Drug Transport. Front Mol Neurosci 2018;11:166.

27. Reitsma S, Slaaf DW, Vink H, et al. The endothelial glycocalyx: composition, functions, and visualization. Pflugers Arch 2007; 454(3):345-359.

28. Urich E, Lazic SE, Molnos J, et al. Transcriptional profiling of human brain endothelial cells reveals key properties crucial for predictive in vitro blood-brain barrier models. PLoS One 2012; 7(5):e38149.

29. Villaseñor R, Kuennecke B, Ozmen L, et al. Region-specific permeability of the blood-brain barrier upon pericyte loss. J Cereb Blood Flow Metab 2017; 37(12):36833694

30. Nakagawa S, Deli MA, Kawaguchi H, et al. A new blood-brain barrier model using primary rat brain endothelial cells, pericytes and astrocytes. Neurochem Int 2009; 54(3-4):253-263.

31. Thomsen LB, Burkhart A and Moos T. A Triple Culture Model of the Blood-Brain Barrier Using Porcine Brain Endothelial cells, Astrocytes and Pericytes. PLoS One 2015;10(8):e0134765.

32. Mossu A, Rosito M, Khire T, et al. A silicon nanomembrane platform for the visualization of immune cell trafficking across the human blood-brain barrier under flow. J Cereb Blood Flow Metab 2019;39(3):395-410.

33. Colgan OC, Ferguson G, Collins NT, et al. Regulation of bovine brain microvascular endothelial tight junction assembly and barrier function by laminar shear stress. Am J Physiol Heart Circ Physiol 2007; 292(6):H3190-H3197.

34. Ando $\mathbf{J}$ and Kamiya A. Flow-dependent regulation of gene expression in vascular endothelial cells. Jpn Heart J 1996; 37(1):19-32.

35. Dragoni S and Turowski P. Polarised VEGFA Signalling at Vascular Blood-Neural Barriers. Int J Mol Sci 2018;19(5):1378.

36. Rempe RG, Hartz AMS and Bauer B. Matrix metalloproteinases in the brain and blood-brain barrier: Versatile breakers and makers. J Cereb Blood Flow Metab 2016; 36(9):1481-1507. 


\section{Supplementary material to}

Flow induces glycocalyx-related genes and negative surface charge in a lab-on-achip human blood-brain barrier model

Ana R. Santa-Maria ${ }^{1,2}$, Fruzsina R. Walter ${ }^{1}$, Ricardo Figueiredo ${ }^{3,4}$, András Kincses ${ }^{1,5}$, Marjolein Heymans ${ }^{6}$, Maxime Culot $^{6}$, Peter Winter ${ }^{3}$, Fabien Gosselet ${ }^{6}$, András Dér ${ }^{1}$, Maria A. Deli ${ }^{1, *}$

${ }^{1}$ Institute of Biophysics, Biological Research Centre, Temesvári krt. 62, H-6726, Szeged, Hungary

${ }^{2}$ Doctoral School of Biology, University of Szeged, Közép fasor 52, H-6726, Szeged, Hungary

${ }^{3}$ GenXPro GmbH, Altenhöferallee 3, D-60438, Frankfurt-Am-Main, Germany

${ }^{4}$ Johann Wolfgang Goethe University Frankfurt, Frankfurt-Am-Main, Germany

${ }^{5}$ Doctoral School of Multidisciplinary Medical Sciences, University of Szeged, Tisza Lajos körút 109., H-6725, Szeged, Hungary

${ }^{6}$ Univ. Artois, UR 2465, Laboratoire de la Barrière Hémato-Encéphalique (LBHE), F62300 Lens, France

* Corresponding author:

Mária A. Deli,

Institute of Biophysics, Biological Research Centre, Temesvári krt 62, H-6726, Szeged, Hungary

Tel. +36-62-599602

e-mail: deli.maria@brc.hu 


\section{Methods}

\section{LOC device}

The device was built as described in our previous publication. ${ }^{5}$ Briefly, the top and bottom channels were fabricated from poly(dimethylsiloxane) (PDMS, Sylgard 184, Dow Corning $\mathrm{GmbH}$, Wiesbaden, Germany), separated by a porous membrane (PET, $0.45 \mu \mathrm{m}$ pore size, $2 \times 10^{6} / \mathrm{cm}^{2}$ pore density and $23 \mu \mathrm{m}$ thickness; It4ip, Louvain-la-Neuve, Belgium) (Figure 1(a)). The length, width and height of the top and bottom channels were $36 \mathrm{~mm} \times 2 \mathrm{~mm} \times 1 \mathrm{~mm}$ and $57 \mathrm{~mm} \times 2 \mathrm{~mm} \times 2 \mathrm{~mm}$, respectively. Gold electrodes (thickness: $25 \mathrm{~nm}$ ) were formed on the plastic microscope slides using sputter-coating, providing low resistance to allow transendothelial electrical resistance (TEER) measurements and good visibility to monitor cell growth by phase contrast microscopy throughout the whole length of the channel. ${ }^{5}$ The electrodes were linked connected with copper wires to a 4channel voltohmmeter (EVOM ${ }^{2}$; World Precision Instruments Inc., Sarasota, FL, USA). The PDMS channels were sandwiched between the plastic slides, and closed with plastic screws (Figure 1(a)). The device was sterilized with oxygen plasma for 5 min and $70 \%$ ethanol for $30 \mathrm{~min}$ before cells were seeded to the system.

\section{Cell culture of the human endothelial cells and bovine pericytes}

The in vitro BBB model, consisting of human endothelial cells in co-culture with bovine brain pericytes, was described by Cecchelli et al., 2014 and is named brain-like endothelial cells (BLECs). The isolation of $\mathrm{CD} 34^{+}$cells required the collection of human umbilical cord blood from infants, which was approved by the Hospital ethical committee (Béthune Maternity Hospital, Béthune, France). Infants' parents signed an informed consent form, in compliance with the French legislation. The protocol was approved by the French Ministry of Higher Education and Research (CODECOH Number DC20111321). All experiments were carried out in accordance with the approved protocol and the World Medical Association Declaration of Helsinki. Briefly, the hematopoietic stem cells were isolated from human cord blood and differentiated to endothelial cells as previously published (Pedroso et al., 2011). These human endothelial cells (hEC) were seeded in $0.2 \%$ gelatin (type A from porcine skin) coated culture dishes and kept in endothelial cell culture medium (ECM, Sciencell, Carlsbad, CA, USA) supplemented with $5 \%$ fetal bovine serum (FBS, heat inactivated), $1 \%$ endothelial cell growth supplement (ECGS, Sciencell), and gentamycin $(50 \mu \mathrm{g} / \mathrm{ml})$. After reaching confluency, usually 2 days after seeding, hECs were gently trypsinized and $80 \times 10^{3}$ cells seeded into the porous polyester membrane of the lab-on-a-chip (LOC) device (Figure 1(b)). The membrane was coated with Matrigel (growth factor reduced BD Matrigel Matrix, BD Biosciences, Franklin Lakes, NJ, USA) at a dilution of 1:48.

Bovine brain pericytes (PCs) were isolated from brain microvessels as described earlier (Cecchelli et al., 2014). Permission for the protocol was obtained from the Ethical Committee of the University of Artois. Experiments were made according to "Guidance on good cell culture practice. A report of the second ECVAM task force on good cell culture practice" (Coecke et al., 2005). PCs were cultured in $0.2 \%$ gelatin coated dishes in Dulbecco's modified Eagle's medium (DMEM, Life Technologies, Thermo Fisher Scientific, Waltham, MA, USA) supplemented with 20\% FBS, 1\% Glutamax (Life Technologies) and gentamicin $(50 \mu \mathrm{g} / \mathrm{ml})$. Cells were kept in culture until reaching confluency. Then, PCs were trypsinized and $25 \times 10^{3}$ cells were added to the bottom compartment of the LOC device, which was coated with $0.2 \%$ gelatin. The co-culture 
started when PCs were added (Figure 1(b)). During co-culture both compartments received hEC medium. The $\mathrm{LOC}$ device with the cells was kept at $37^{\circ} \mathrm{C}$ in a humified atmosphere and $5 \% \mathrm{CO}_{2}$.

The human in vitro BBB model used for static Transwell cell culture inserts was the same as described above. In this case the BLEC were cultured on a cell culture insert (PET, $0.4 \mu \mathrm{m}$ pore size, 12-well system, Costar, Corning Incorporated) coated with Matrigel, at a density of $8 \times 10^{4}$ cells as described previously (Cecchelli et al., 2014; Heymans et al., 2020). For the co-culture, brain pericytes were trypsinized and seeded at a concentration of $2.5 \times 10^{4}$ cells on the bottom of $0.2 \%$ gelatin-coated 12 -well plates (Costar, Corning Incorporated). During the 7 days of culture cells were kept in a $\mathrm{CO}_{2}$ incubator at $37^{\circ} \mathrm{C}$, with $5 \% \mathrm{CO}_{2}$.

\section{Static culture conditions in the LOC device}

For the static condition, a $20 \mathrm{ml}$ plastic disposable syringe with Luer cone (B. Braun, Melsungen, Germany) containing cell culture medium was placed in a syringe pump (Legato 110, KD Scientific, Holliston, MA, USA) and connected to the inlets/outlets of the LOC device via female Luer locks (Rotilabo, Carl Roth, Karlsruhe, Germany) using plastic tubes ( $1 \mathrm{~mm}$ inner, $3 \mathrm{~mm}$ outer diameter, Carl Roth). For the first six days of the dynamic condition and all the seven days of the static condition the syringe was programmed to change medium above the BLEC monolayer every 8 hours at $500 \mu \mathrm{l} / \mathrm{min}$ flow rate. The medium in the lower compartment containing PCs was changed manually daily.

\section{Barrier integrity measurement: permeability}

In order to assess the differences between the integrity of BBB models kept in static or dynamic condition we measured the flux of two fluorescent markers of permeability. To assess the barrier integrity small molecular weight marker lucifer yellow (LY, MW: 457 Da) (Cecchelli 2014) and Evans blue dye bound to $1 \%$ bovine serum albumin (EBA, MW: $67.5 \mathrm{kDa}$ ) (Walter 2016) were used. For the assay medium in the upper compartments of the LOC devices was replaced with $150 \mu 1$ of Ringer-Hepes solution (118 mM NaCl, $4.8 \mathrm{mM} \mathrm{KCl}, 2.5 \mathrm{mM} \mathrm{CaCl}_{2}, 1.2 \mathrm{mM} \mathrm{MgSO}_{4}, 5.5 \mathrm{mM}$ D-glucose, 10 $\mathrm{mM}$ HEPES, $\mathrm{pH}$ 7.4) containing $1 \%$ bovine serum albumin (BSA), $1 \%$ InsulinTransferrin-Selenium supplement (ITS, Life Technologies), LY $(5 \mu \mathrm{M})$ and EBA (165 $\mu \mathrm{g} / \mathrm{ml}$ dye bound to $1 \% \mathrm{BSA}$ ). In the bottom compartments, culture medium was changed to $350 \mu \mathrm{l}$ of Ringer-Hepes solution with $1 \%$ BSA and $1 \%$ ITS. LOCs were incubated for 20, 40 and 60 minutes in a $\mathrm{CO}_{2}$ incubator at $37{ }^{\circ} \mathrm{C}$ on a horizontal shaker $(150 \mathrm{rpm} / \mathrm{min})$. Samples were collected from both compartments and fluorescent intensity measured by spectrofluorometer (Horiba Jobin Yvon Fluorolog 3, Kyoto, Japan) at $420 \mathrm{~nm}$ excitation and $535 \mathrm{~nm}$ emission wavelengths for LY and $582 \mathrm{~nm}$ excitation and $662 \mathrm{~nm}$ emission wavelengths for EBA.

Concentrations of each marker were determined by plotting them to a calibration curve. First, the clearance $(\mu \mathrm{l})$ was calculated with the help of the following equation:

$$
C l=\frac{[C]_{a b} \times V_{a b}}{[C]_{l}}
$$

where $\mathrm{Cl}$ is the clearance, $[\mathrm{C}]_{\mathrm{ab}}$ and $\mathrm{V}_{\mathrm{ab}}$ represent the concentration and volume $(\mu \mathrm{l})$ of the abluminal (acceptor) compartment, and $[\mathrm{C}]_{1}$ represents the luminal (donor) 
concentration. Clearance values of the markers were plotted separately against time and the slope values were used to calculate the apparent permeability coefficient $\left(\mathrm{P}_{\text {app }}\right)$ from the following equation:

$$
P_{a p p}=\frac{P S}{A}
$$

where PS is the permeability surface area product (clearance rate in $\mu 1 / \mathrm{min}$ ) of the BBB models on the membranes, $\mathrm{A}$ is the surface area of the membrane $\left(0.8 \mathrm{~cm}^{2}\right)$.

\section{Immunohistochemistry}

To evaluate the morphology of hECs kept in dynamic or static condition, cells were fixed with ice cold methanol and acetone solution (1:1) for 2 minutes. The membranes with cells were washed twice with phosphate buffered saline (PBS) containing 1\% FBS and the non-specific binding sites were blocked with $3 \%$ BSA in PBS for 1 hour at room temperature. The primary antibodies rabbit anti- $\beta$-catenin (\#C2206, Sigma, 1:300), and rabbit anti-claudin-5 (SAB4502981, Sigma, 1:300) were both diluted in $3 \%$ BSA-PBS blocking buffer and incubated with the samples overnight at $4{ }^{\circ} \mathrm{C}$. Next day cells were washed three times with PBS and incubated with secondary antibody anti-rabbit IgGCY3 (C2306, Sigma, 1:400) and the H33342 dye $(1 \mu \mathrm{g} / \mathrm{ml})$ in PBS for 1 hour at room temperature. The same protocol was used to stain bovine brain PCs with primary antibodies mouse anti- $\alpha$-SM-actin (A2547, Sigma, 1:200), rabbit anti-NG2 (AB5320, Millipore, Merck, Darmstadt, Germany, 1:200) and rabbit anti-PDGFR- $\beta$ (ab32570, AbCam, Cambridge, UK, 1:200). Alexa fluor 488 anti-mouse IgG (A11029, Invitrogen, 1:400), anti-rabbit IgG-CY3 (C2306, Sigma, 1:400) and H33342 dye ( $1 \mu \mathrm{g} / \mathrm{ml})$ were used as a secondary antibodies and staining cell nuclei, respectively. After mounting the samples in Fluoromount-G (Southern Biotech, Birmingham, AL, USA) staining of samples was visualized by a Leica TCS SP5 confocal laser scanning microscope (Leica Microsystems, Wetzlar, Germany).

\section{Total RNA isolation}

After 24-hour static or dynamic condition, hECs were removed from the LOC devices by very fast and gentle trypsinization and RNA was isolated using RNeasy Plus Micro Kit (Qiagen, Hilden, Germany) following the manufacturer's instructions. Integrated gDNA eliminator spin column allows DNA depletion from RNA samples. RNA integrity (supplementary Figure 2) was analyzed using automated capillary electrophoresis (RNA Pico Sensitivity Assay, LabChip GX II Touch HT, Perkin Elmer, Waltham, MA, USA). RNA samples were stored at $-80{ }^{\circ} \mathrm{C}$ until further analysis.

\section{RNA sequencing and generation of MACE-seq libraries}

Samples with $100 \mathrm{ng}$ of purified RNA were used for library preparation. RNA was fragmented using GenXPro Fragmentation Buffer. Synthesis of cDNA was performed by reverse transcription using barcoded oligo(dT) primers containing TrueQuant unique molecular identifiers, followed by template switching. Library amplification was done using polymerase chain reaction (PCR), purified by solid phase reversible immobilization beads (Agencourt AMPure XP, Beckman Coulter, Brea, CA, USA) and subsequent sequencing was performed using a NextSeq platform (Illumina Inc., San Diego, CA, USA). 


\section{Zeta potential measurements}

The zeta potential was measured at $25{ }^{\circ} \mathrm{C}$, from a minimum of 6 measurements (maximum 100 runs for each) with an applied voltage of $20 \mathrm{~V}$. The disposable zeta potential cuvettes, equipped with gold plated beryllium/copper electrodes (DTS1070, Malvern, UK), were activated before the initial measurements with $100 \%$ methanol and rinsed with distilled water twice, then calibrated with a zeta standard solution as described in the manufacturer's protocol. After 24-hour dynamic and static condition hECs were quickly and gently trypsinized, centrifuged and $10^{5}$ cells were pipetted in $900 \mu \mathrm{L} \mathrm{PBS}$ with $\mathrm{Ca}^{2+}$ and $\mathrm{Mg}^{2+}$ into the cuvettes and zeta potential was measured. The Zetasizer Software v.7.12. calculated the zeta potential values (in $\mathrm{mV}$ ) using the Smoluchowski equation.

The co-culture of hEC with brain pericytes was performed on the cell culture inserts as described above and was compared with the monocultures of the hEC. The zeta measurement and the fluorescently labeled wheat germ agglutinin staining labeling of sialic acid and $\mathrm{N}$-acetyl-D-glucosamine residues within the glycocalyx were done as described for cells in the LOC device.

\section{References}

Coecke S, Balls M, Bowe G, et al. Guidance on good cell culture practice. a report of the second ECVAM task force on good cell culture practice. Altern Lab Anim. 2005 Jun;33(3):261-87.

Cecchelli R, Aday S, Sevin E, et al. A stable and reproducible human blood-brain barrier model derived from hematopoietic stem cells. PLoS One 2014;9(6):e99733.

Heymans M, Figueiredo R, Dehouck L, et al. Contribution of brain pericytes in blood-brain barrier formation and maintenance: a transcriptomic study of cocultured human endothelial cells derived from hematopoietic stem cells. Fluids Barriers CNS 2020;17(1):48.

Pedroso DC, Tellechea A, Moura L, Fidalgo-Carvalho I, Duarte J, Carvalho E, Ferreira L. Improved survival, vascular differentiation and wound healing potential of stem cells cocultured with endothelial cells. PLoS One. 2011 Jan 24;6(1):e16114.

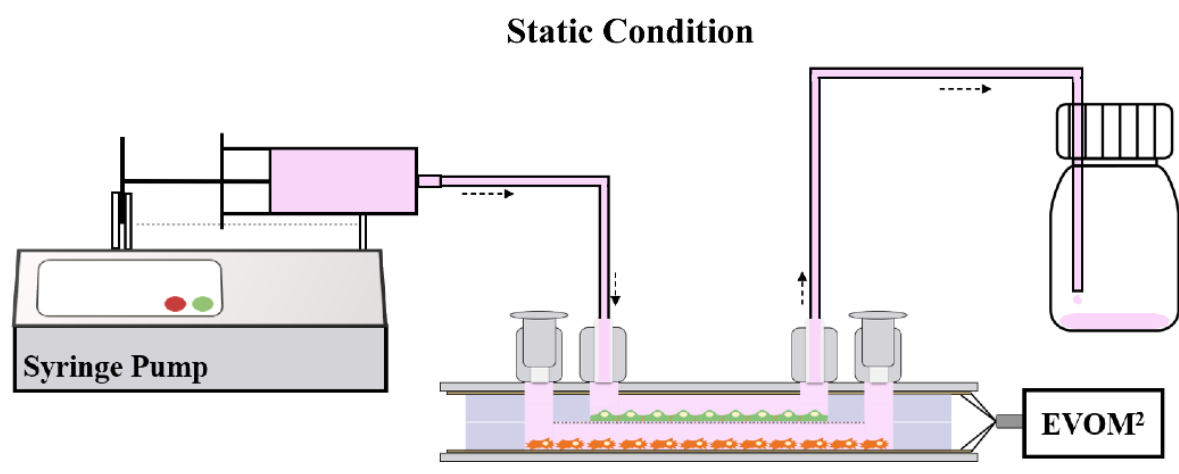

Supplementary Figure S1. Static condition: a syringe containing the cell culture medium was placed in a syringe pump (on the left), which allowed automatic medium change through the top compartment every 8 hours with a fluid flow of $500 \mu \mathrm{L} / \mathrm{min}$, for 4 minutes. A reservoir was connected to the LOC to collect the discarded medium. 
(a)

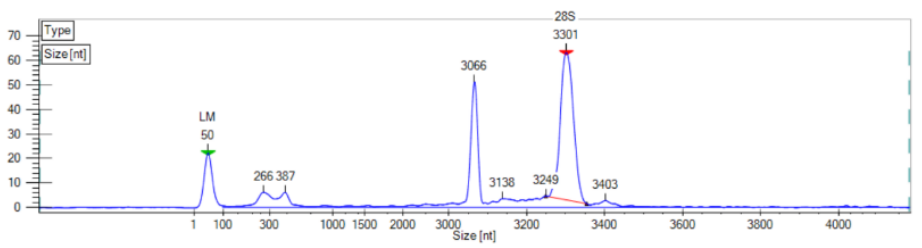

(b)

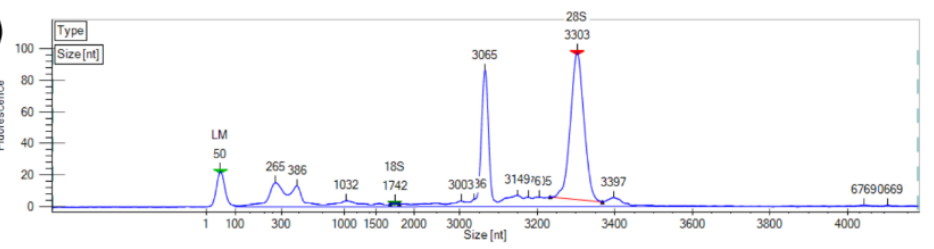

(c)

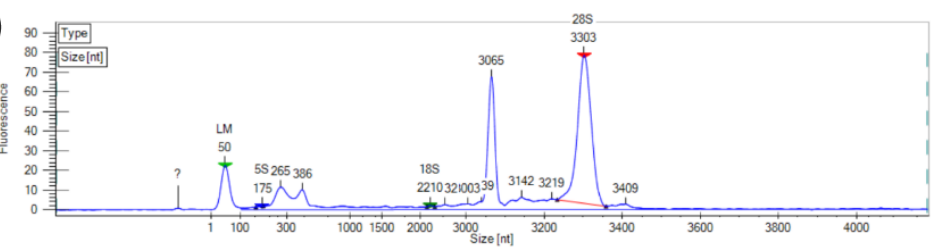

(d)

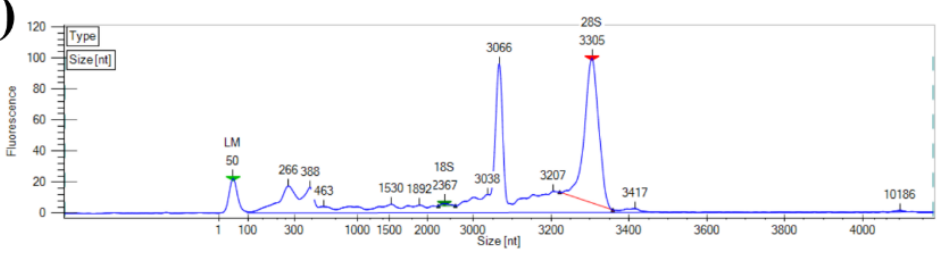

(e)

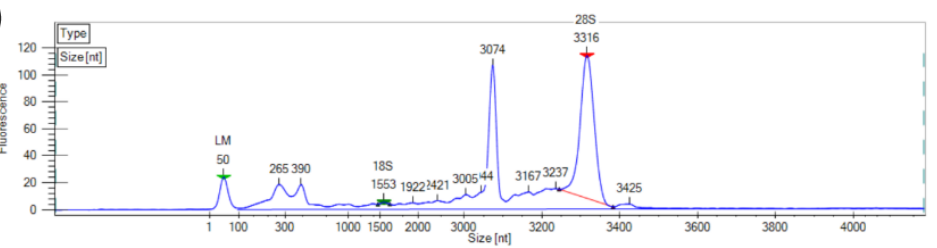

(f)

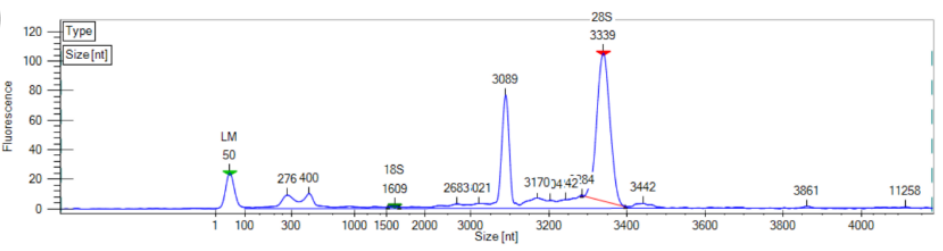

(g)

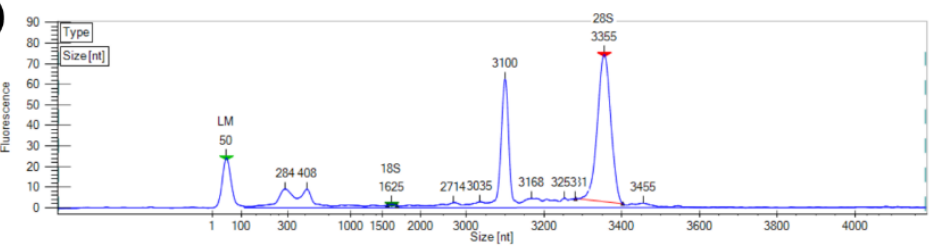

(h)

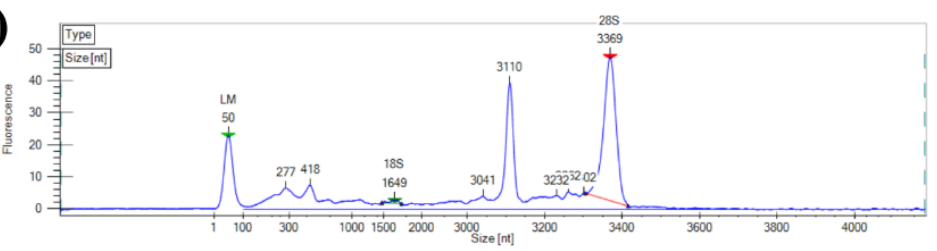

Supplementary Figure S2. Quality control for RNA for each sequenced sample. (a)-(e) Dynamic condition samples. (f)-(h) Static condition samples. 
(a)

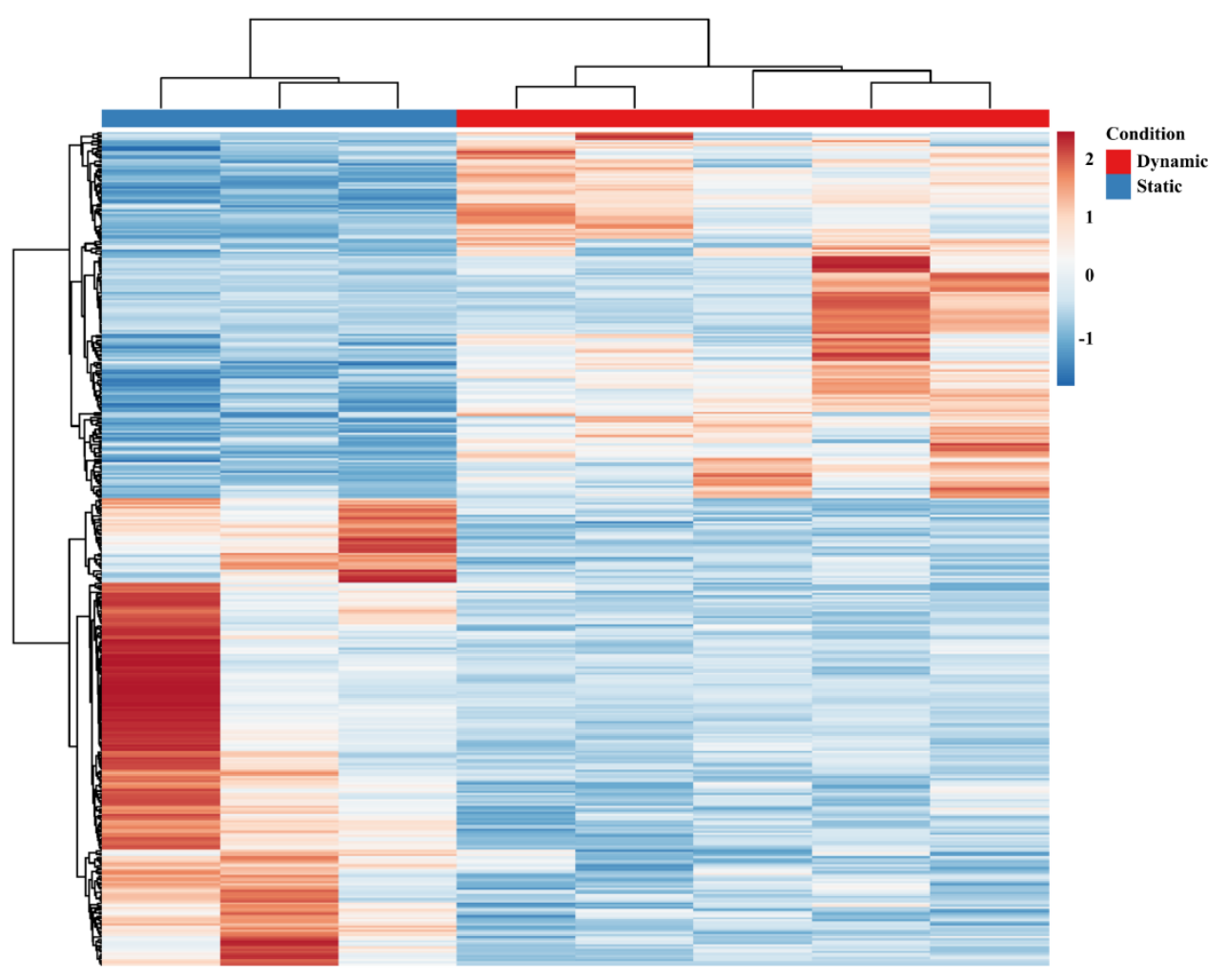

(b)

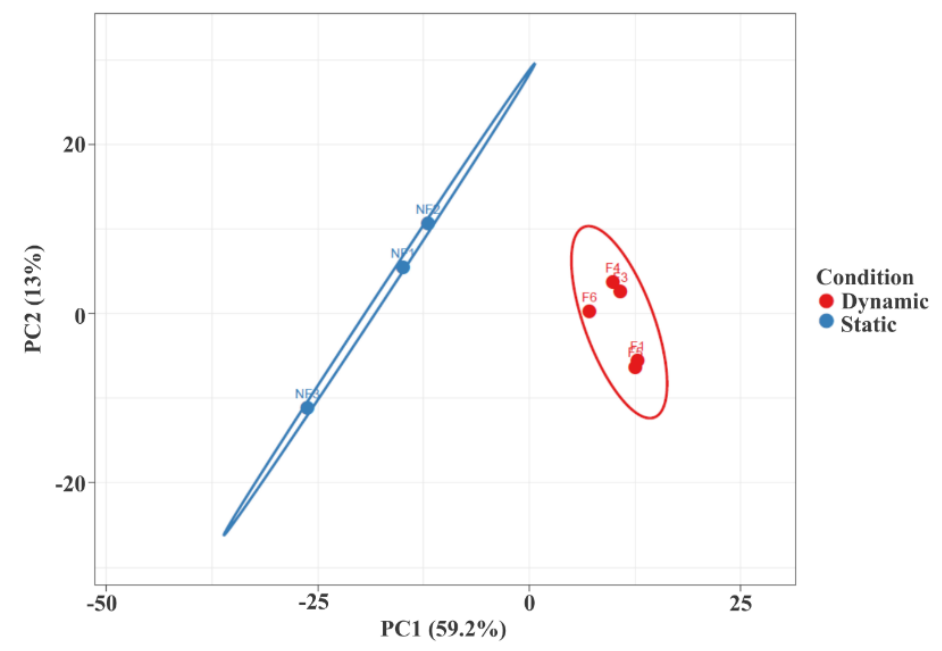

Supplementary Figure S3. General transcriptomic profile. (a) Heat map of all differentially expressed genes. Data input consisted of the normalized expression in flow condition(dynamic) compared with no flow condition (static). Unit variance scaling is applied to rows. (b) Principal component (PC) analysis and hierarchical clustering were used to assess relatedness between samples. 
Supplementary Table S1. Top 50 differentially expressed genes in the human BBB model in dynamic condition. Colors highlight the genes discussed in the results section of the study. Red color labels gene upregulation and blue color shows gene downregulation.

\begin{tabular}{|c|c|c|c|}
\hline Gene symbol & Description & P-value & $\log 2 \mathrm{FC}$ \\
\hline TSPAN15 & tetraspanin 15 & $1,43 \mathrm{E}-34$ & 1,33 \\
\hline CYP1A1 & cytochrome P450 family 1 subfamily A member 1 & $1,42 \mathrm{E}-25$ & 2,70 \\
\hline PLVAP & plasmalemma vesicle associated protein & $4,13 \mathrm{E}-23$ & 1,95 \\
\hline MMP10 & matrix metallopeptidase 10 & $5,29 \mathrm{E}-23$ & 2,16 \\
\hline TGFBI & transforming growth factor beta induced & $6,51 \mathrm{E}-19$ & 1,86 \\
\hline PMEPA1 & prostate transmembrane protein, androgen induced 1 & $1,62 \mathrm{E}-18$ & 1,51 \\
\hline SNAI1 & snail family transcriptional repressor 1 & $3,84 \mathrm{E}-18$ & 1,49 \\
\hline ANPEP & alanyl aminopeptidase, membrane & $7,61 \mathrm{E}-14$ & 1,11 \\
\hline ALDH1A2 & aldehyde dehydrogenase 1 family member A2 & $2,98 \mathrm{E}-13$ & $-1,93$ \\
\hline GJA5 & gap junction protein alpha 5 & $1,61 \mathrm{E}-12$ & 2,69 \\
\hline SPSB1 & splA/ryanodine receptor domain and SOCS box containing 1 & $1,67 \mathrm{E}-12$ & 1,24 \\
\hline MEF2C & myocyte enhancer factor $2 \mathrm{C}$ & $2,19 \mathrm{E}-12$ & $-1,05$ \\
\hline RASD1 & ras related dexamethasone induced 1 & $1,08 \mathrm{E}-11$ & 2,05 \\
\hline CCL2 & C-C motif chemokine ligand 2 & $1,27 \mathrm{E}-11$ & 1,61 \\
\hline ICAM1 & intercellular adhesion molecule 1 & $1,49 \mathrm{E}-11$ & 1,38 \\
\hline KRT19 & keratin 19 & $6,39 \mathrm{E}-11$ & $-1,75$ \\
\hline HTRA1 & HtrA serine peptidase 1 & $2,01 \mathrm{E}-10$ & 1,08 \\
\hline NR5A2 & nuclear receptor subfamily 5 group A member 2 & $6,40 \mathrm{E}-10$ & $-1,47$ \\
\hline ENG & endoglin & $9,97 \mathrm{E}-10$ & 1,02 \\
\hline CRLF1 & cytokine receptor like factor 1 & $1,16 \mathrm{E}-09$ & 2,64 \\
\hline PDLIM1 & PDZ and LIM domain 1 & $1,71 \mathrm{E}-09$ & $-1,15$ \\
\hline AKR1C3 & aldo-keto reductase family 1 member C3 & $4,97 \mathrm{E}-09$ & 1,21 \\
\hline CXCL6 & $\mathrm{C}-\mathrm{X}-\mathrm{C}$ motif chemokine ligand 6 & $7,74 \mathrm{E}-09$ & $-2,15$ \\
\hline SERINC2 & serine incorporator 2 & $8,76 \mathrm{E}-09$ & 1,17 \\
\hline TAGLN & transgelin & $1,88 \mathrm{E}-08$ & 1,94 \\
\hline NR4A1 & nuclear receptor subfamily 4 group A member 1 & $4,41 \mathrm{E}-08$ & $-3,57$ \\
\hline PSAT1 & phosphoserine aminotransferase 1 & $4,73 \mathrm{E}-08$ & $-1,04$ \\
\hline MAN1C1 & mannosidase alpha class $1 \mathrm{C}$ member 1 & $5,51 \mathrm{E}-08$ & $-2,45$ \\
\hline LYVE1 & lymphatic vessel endothelial hyaluronan receptor 1 & $5,83 \mathrm{E}-08$ & $-3,69$ \\
\hline TMCC3 & transmembrane and coiled-coil domain family 3 & $7,08 \mathrm{E}-08$ & $-1,22$ \\
\hline LAPTM5 & lysosomal protein transmembrane 5 & $1,23 \mathrm{E}-07$ & 1,25 \\
\hline FAM129A & family with sequence similarity 129 member A & $2,00 \mathrm{E}-07$ & $-2,66$ \\
\hline DIRAS3 & DIRAS family GTPase 3 & $2,17 \mathrm{E}-07$ & $-1,76$ \\
\hline SLC2A6 & solute carrier family 2 member 6 & $2,32 \mathrm{E}-07$ & 1,11 \\
\hline NQO1 & NAD(P)H quinone dehydrogenase 1 & $2,32 \mathrm{E}-07$ & 1,13 \\
\hline ADORA2A & adenosine $\mathrm{A} 2 \mathrm{a}$ receptor & $2,61 \mathrm{E}-07$ & $-1,31$ \\
\hline AC078850.1 & NA & $2,75 \mathrm{E}-07$ & $-1,90$ \\
\hline COL4A1 & collagen type IV alpha 1 chain & $6,38 \mathrm{E}-07$ & 1,12 \\
\hline PAPPA & pappalysin 1 & $9,14 \mathrm{E}-07$ & 2,56 \\
\hline EXOC3L1 & exocyst complex component 3 like 1 & $1,01 \mathrm{E}-06$ & 2,81 \\
\hline OSGIN1 & oxidative stress induced growth inhibitor 1 & $1,25 \mathrm{E}-06$ & 1,43 \\
\hline CHST1 & carbohydrate sulfotransferase 1 & $1,67 \mathrm{E}-06$ & 1,22 \\
\hline LRRC8B & leucine rich repeat containing 8 VRAC subunit B & $1,89 \mathrm{E}-06$ & $-1,07$ \\
\hline VCAN & versican & $2,38 \mathrm{E}-06$ & 3,89 \\
\hline SLC7A2 & solute carrier family 7 member 2 & $2,65 \mathrm{E}-06$ & 1,24 \\
\hline F2RL3 & F2R like thrombin or trypsin receptor 3 & $4,09 \mathrm{E}-06$ & 2,17 \\
\hline TNFSF15 & TNF superfamily member 15 & $5,87 \mathrm{E}-06$ & 1,22 \\
\hline DUSP5 & dual specificity phosphatase 5 & $5,97 \mathrm{E}-06$ & $-1,37$ \\
\hline NAB2 & NGFI-A binding protein 2 & $6,92 \mathrm{E}-06$ & $-1,13$ \\
\hline PANX2 & pannexin 2 & $7,59 \mathrm{E}-06$ & 1,37 \\
\hline
\end{tabular}


Supplementary Table S2. Top 50 upregulated genes in the human BBB model in dynamic condition. Red color highlight the genes discussed in the results section of the study.

\begin{tabular}{|c|c|c|c|}
\hline Gene symbol & Description & P-value & Log2FC \\
\hline TSPAN15 & tetraspanin 15 & $1,43 \mathrm{E}-34$ & 1,33 \\
\hline CYP1A1 & cytochrome P450 family 1 subfamily A member 1 & $1,42 \mathrm{E}-25$ & 2,70 \\
\hline PLVAP & plasmalemma vesicle associated protein & $4,13 \mathrm{E}-23$ & 1,95 \\
\hline MMP10 & matrix metallopeptidase 10 & $5,29 \mathrm{E}-23$ & 2,16 \\
\hline TGFBI & transforming growth factor beta induced & $6,51 \mathrm{E}-19$ & 1,86 \\
\hline PMEPA1 & prostate transmembrane protein, androgen induced 1 & $1,62 \mathrm{E}-18$ & 1,51 \\
\hline SNAI1 & snail family transcriptional repressor 1 & $3,84 \mathrm{E}-18$ & 1,49 \\
\hline ANPEP & alanyl aminopeptidase, membrane & $7,61 \mathrm{E}-14$ & 1,11 \\
\hline GJA5 & gap junction protein alpha 5 & $1,61 \mathrm{E}-12$ & 2,69 \\
\hline SPSB1 & splA/ryanodine receptor domain and SOCS box containing 1 & $1,67 \mathrm{E}-12$ & 1,24 \\
\hline RASD1 & ras related dexamethasone induced 1 & $1,08 \mathrm{E}-11$ & 2,05 \\
\hline CCL2 & $\mathrm{C}-\mathrm{C}$ motif chemokine ligand 2 & $1,27 \mathrm{E}-11$ & 1,61 \\
\hline ICAM1 & intercellular adhesion molecule 1 & $1,49 \mathrm{E}-11$ & 1,38 \\
\hline HTRA1 & HtrA serine peptidase 1 & $2,01 \mathrm{E}-10$ & 1,08 \\
\hline ENG & endoglin & $9,97 \mathrm{E}-10$ & 1,02 \\
\hline CRLF1 & cytokine receptor like factor 1 & $1,16 \mathrm{E}-09$ & 2,64 \\
\hline AKR1C3 & aldo-keto reductase family 1 member $\mathrm{C} 3$ & 4,97E-09 & 1,21 \\
\hline SERINC2 & serine incorporator 2 & $8,76 \mathrm{E}-09$ & 1,17 \\
\hline TAGLN & transgelin & $1,88 \mathrm{E}-08$ & 1,94 \\
\hline LAPTM5 & lysosomal protein transmembrane 5 & $1,23 \mathrm{E}-07$ & 1,25 \\
\hline SLC2A6 & solute carrier family 2 member 6 & $2,32 \mathrm{E}-07$ & 1,11 \\
\hline NQO1 & $\mathrm{NAD}(\mathrm{P}) \mathrm{H}$ quinone dehydrogenase 1 & $2,32 \mathrm{E}-07$ & 1,13 \\
\hline COL4A1 & collagen type IV alpha 1 chain & $6,38 \mathrm{E}-07$ & 1,12 \\
\hline PAPPA & pappalysin 1 & $9,14 \mathrm{E}-07$ & 2,56 \\
\hline EXOC3L1 & exocyst complex component 3 like 1 & $1,01 \mathrm{E}-06$ & 2,81 \\
\hline OSGIN1 & oxidative stress induced growth inhibitor 1 & $1,25 \mathrm{E}-06$ & 1,43 \\
\hline CHST1 & carbohydrate sulfotransferase 1 & $1,67 \mathrm{E}-06$ & 1,22 \\
\hline VCAN & versican & $2,38 \mathrm{E}-06$ & 3,89 \\
\hline SLC7A2 & solute carrier family 7 member 2 & $2,65 \mathrm{E}-06$ & 1,24 \\
\hline F2RL3 & F2R like thrombin or trypsin receptor 3 & $4,09 \mathrm{E}-06$ & 2,17 \\
\hline TNFSF15 & TNF superfamily member 15 & $5,87 \mathrm{E}-06$ & 1,22 \\
\hline PANX2 & pannexin 2 & $7,59 \mathrm{E}-06$ & 1,37 \\
\hline MYLK2 & myosin light chain kinase 2 & $1,27 \mathrm{E}-05$ & 2,33 \\
\hline SERPINE2 & serpin family E member 2 & $1,42 \mathrm{E}-05$ & 1,41 \\
\hline RASA4 & RAS $\mathrm{p} 21$ protein activator 4 & $2,40 \mathrm{E}-05$ & 1,44 \\
\hline DYRK1B & dual specificity tyrosine phosphorylation regulated kinase $1 \mathrm{~B}$ & $3,57 \mathrm{E}-05$ & 1,05 \\
\hline SERPINE1 & serpin family E member 1 & $3,66 \mathrm{E}-05$ & 1,17 \\
\hline RASA4B & RAS $\mathrm{p} 21$ protein activator $4 \mathrm{~B}$ & $4,10 \mathrm{E}-05$ & 1,51 \\
\hline RFX2 & regulatory factor $\mathrm{X} 2$ & $4,31 \mathrm{E}-05$ & 1,13 \\
\hline LFNG & $\begin{array}{l}\text { LFNG O-fucosylpeptide 3-beta-N- } \\
\text { acetylglucosaminyltransferase }\end{array}$ & 4,44E-05 & 1,02 \\
\hline LIPG & lipase $\mathrm{G}$, endothelial type & $6,65 \mathrm{E}-05$ & 2,26 \\
\hline ITGA11 & integrin subunit alpha 11 & $8,03 \mathrm{E}-05$ & 1,33 \\
\hline ZNF704 & zinc finger protein 704 & 0,000119 & 1,01 \\
\hline SEMA3G & semaphorin $3 \mathrm{G}$ & 0,000127 & 2,65 \\
\hline SLC25A34-AS1 & SLC25A34 and TMEM82 antisense RNA 1 & 0,000166 & 1,22 \\
\hline ZNF365 & zinc finger protein 365 & 0,000186 & 1,76 \\
\hline SDC2 & syndecan 2 & 0,000205 & 1,22 \\
\hline EPS8L1 & EPS8 like 1 & 0,000228 & 1,08 \\
\hline PCDH9 & protocadherin 9 & 0,000243 & 1,23 \\
\hline MYLK & myosin light chain kinase & 0,000278 & 1,04 \\
\hline
\end{tabular}


Supplementary Table S3. Top 50 downregulated genes in the human BBB model in dynamic condition. Blue color highlight the genes discussed in the results section of the study.

\begin{tabular}{|c|c|c|c|}
\hline Gene symbol & Description & P-value & Log2FC \\
\hline ALDH1A2 & aldehyde dehydrogenase 1 family member $\mathrm{A} 2$ & $2,98 \mathrm{E}-13$ & $-1,93$ \\
\hline MEF2C & myocyte enhancer factor $2 \mathrm{C}$ & $2,19 \mathrm{E}-12$ & $-1,05$ \\
\hline KRT19 & keratin 19 & $6,39 \mathrm{E}-11$ & $-1,75$ \\
\hline NR5A2 & nuclear receptor subfamily 5 group A member 2 & $6,40 \mathrm{E}-10$ & $-1,47$ \\
\hline PDLIM1 & PDZ and LIM domain 1 & $1,71 \mathrm{E}-09$ & $-1,15$ \\
\hline CXCL6 & $\mathrm{C}-\mathrm{X}$-C motif chemokine ligand 6 & $7,74 \mathrm{E}-09$ & $-2,15$ \\
\hline PSAT1 & phosphoserine aminotransferase 1 & $4,73 \mathrm{E}-08$ & $-1,04$ \\
\hline MAN1C1 & mannosidase alpha class $1 \mathrm{C}$ member 1 & $5,51 \mathrm{E}-08$ & $-2,45$ \\
\hline TMCC3 & transmembrane and coiled-coil domain family 3 & $7,08 \mathrm{E}-08$ & $-1,22$ \\
\hline FAM129A & family with sequence similarity 129 member A & $2,00 \mathrm{E}-07$ & $-2,66$ \\
\hline DIRAS3 & DIRAS family GTPase 3 & $2,17 \mathrm{E}-07$ & $-1,76$ \\
\hline ADORA2A & adenosine $\mathrm{A} 2 \mathrm{a}$ receptor & $2,61 \mathrm{E}-07$ & $-1,31$ \\
\hline AC078850.1 & NA & $2,75 \mathrm{E}-07$ & $-1,90$ \\
\hline LRRC8B & leucine rich repeat containing $8 \mathrm{VRAC}$ subunit $\mathrm{B}$ & $1,89 \mathrm{E}-06$ & $-1,07$ \\
\hline DUSP5 & dual specificity phosphatase 5 & $5,97 \mathrm{E}-06$ & $-1,37$ \\
\hline NAB2 & NGFI-A binding protein 2 & $6,92 \mathrm{E}-06$ & $-1,13$ \\
\hline KCNAB1 & potassium voltage-gated channel subfamily A member regulatory beta subunit 1 & $8,14 \mathrm{E}-06$ & $-1,21$ \\
\hline DPP4 & dipeptidyl peptidase 4 & $1,02 \mathrm{E}-05$ & $-1,72$ \\
\hline AGFG2 & ArfGAP with FG repeats 2 & $1,39 \mathrm{E}-05$ & $-1,06$ \\
\hline CLDN7 & claudin 7 & $1,65 \mathrm{E}-05$ & $-1,32$ \\
\hline UCP2 & uncoupling protein 2 & $1,70 \mathrm{E}-05$ & $-1,38$ \\
\hline UBXN2B & UBX domain protein $2 \mathrm{~B}$ & $2,06 \mathrm{E}-05$ & $-1,04$ \\
\hline CCL14 & C-C motif chemokine ligand 14 & $3,60 \mathrm{E}-05$ & $-2,18$ \\
\hline VSIR & V-set immunoregulatory receptor & $6,96 \mathrm{E}-05$ & $-1,24$ \\
\hline METTL7A & methyltransferase like 7A & $9,20 \mathrm{E}-05$ & $-1,04$ \\
\hline WDR27 & WD repeat domain 27 & 0,000103 & $-1,39$ \\
\hline GPRC5A & $\mathrm{G}$ protein-coupled receptor class $\mathrm{C}$ group 5 member $\mathrm{A}$ & 0,00011 & $-1,02$ \\
\hline RHPN1 & rhophilin Rho GTPase binding protein 1 & 0,000189 & $-1,14$ \\
\hline OAS3 & 2'-5'-oligoadenylate synthetase 3 & 0,000214 & $-1,13$ \\
\hline JMJD1C-AS1 & JMJD1C antisense RNA 1 & 0,000245 & $-2,58$ \\
\hline ATP2A3 & ATPase sarcoplasmic/endoplasmic reticulum $\mathrm{Ca} 2+$ transporting 3 & 0,000259 & $-2,24$ \\
\hline AC007998.3 & NA & 0,000283 & $-2,07$ \\
\hline MME & membrane metalloendopeptidase & 0,000289 & $-1,14$ \\
\hline ELMOD1 & ELMO domain containing 1 & 0,000334 & $-2,28$ \\
\hline IL27RA & interleukin 27 receptor subunit alpha & 0,00035 & $-1,15$ \\
\hline SMPDL3B & sphingomyelin phosphodiesterase acid like 3B & 0,000365 & $-1,75$ \\
\hline CDKN2A & cyclin dependent kinase inhibitor $2 \mathrm{~A}$ & 0,000385 & $-1,10$ \\
\hline SLC22A23 & solute carrier family 22 member 23 & 0,000414 & $-1,33$ \\
\hline AC012653.2 & NA & 0,000434 & $-1,32$ \\
\hline G0S2 & G0/G1 switch 2 & 0,000448 & $-1,90$ \\
\hline KHK & ketohexokinase & 0,000478 & $-1,53$ \\
\hline TCF15 & transcription factor 15 & 0,000494 & $-1,41$ \\
\hline N4BP2L1 & NEDD4 binding protein 2 like 1 & 0,000497 & $-1,75$ \\
\hline AQP3 & aquaporin 3 (Gill blood group) & 0,00055 & $-1,22$ \\
\hline RASSF4 & Ras association domain family member 4 & 0,00063 & $-1,25$ \\
\hline RARRES1 & retinoic acid receptor responder 1 & 0,000649 & $-1,82$ \\
\hline KIAA0040 & KIAA0040 & 0,000688 & $-1,52$ \\
\hline ENPP2 & ectonucleotide pyrophosphatase/phosphodiesterase 2 & 0,000695 & $-2,51$ \\
\hline AK5 & adenylate kinase 5 & 0,000796 & $-1,02$ \\
\hline MPZL2 & myelin protein zero like 2 & 0,000883 & $-1,23$ \\
\hline
\end{tabular}


(a)

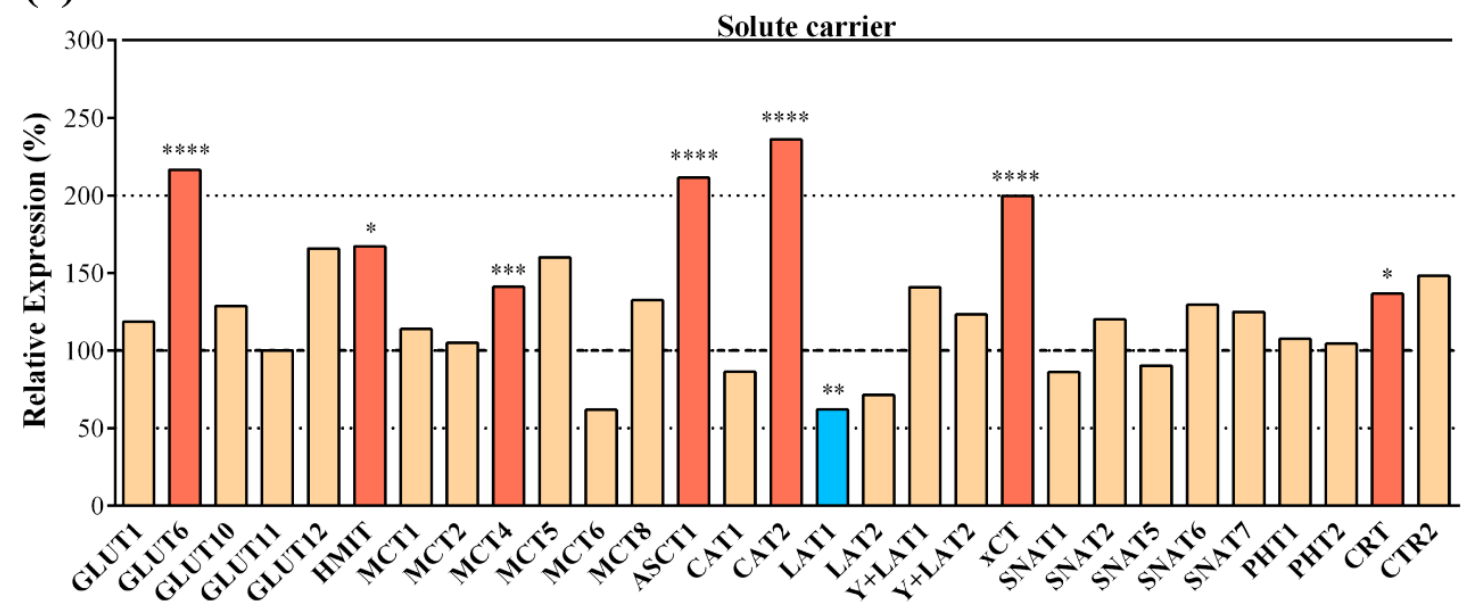

(b)

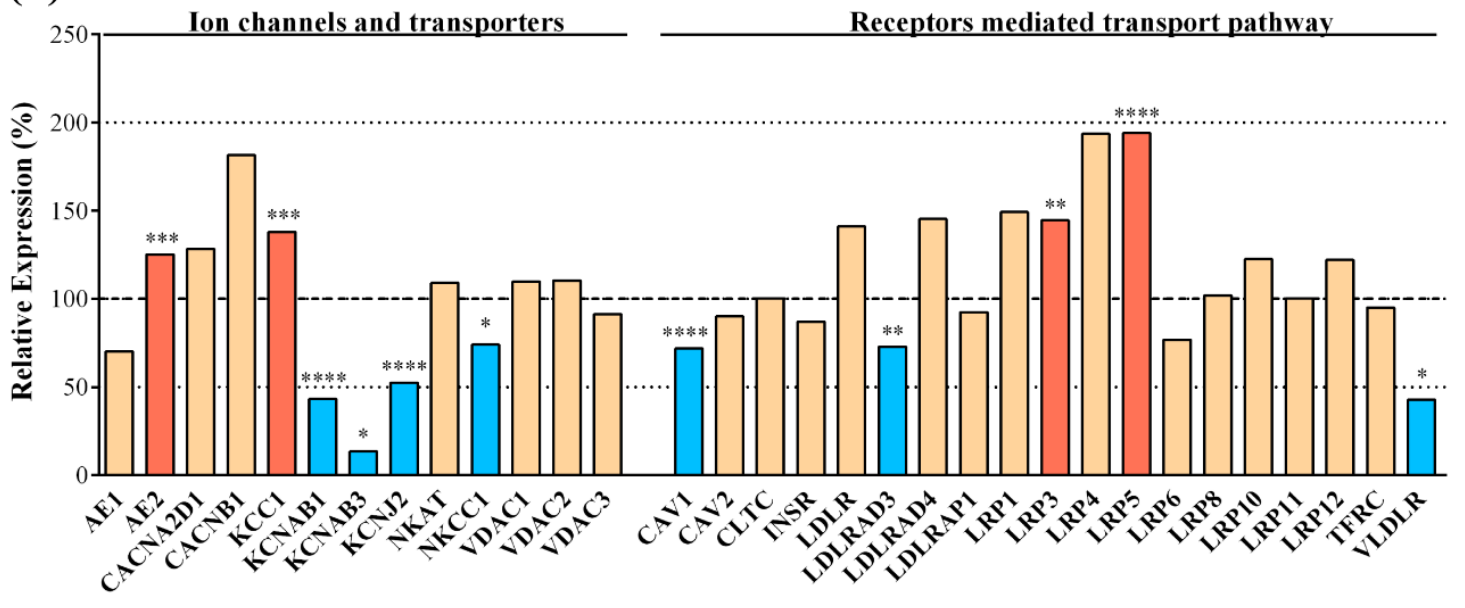

Supplementary Figure S4. Transcriptomic gene expression profile of (a) solute carrier genes and (b) ion channel and transporter, and receptor mediated transport pathway-related genes. Expression is shown as the relative expression (\%) of the genes present in human endothelial cells co-cultured with brain pericytes in dynamic condition as compared to static condition. Genes with a p-value $<0.05$ and less than $50 \%$ or more than $200 \%$ gene expression levels were considered to be differentially expressed. Red color labels upregulation and statistically significant expression changes, blue color shows downregulation and statistically significant expression change, cream color indicates no change in the gene expression $\left(* \mathrm{p}<0.05,{ }^{*} \mathrm{p}<0.01\right.$, $* * * \mathrm{p}<0.001, * * * * \mathrm{p}<0.0001)$.

SLCs are abundantly expressed at the BBB (Daneman et al., 2010; CamposBedolla et al., 2014; Veszelka et al., 2018). Glucose transporters, like SLC2A1 (GLUT1), SLC2A10 (GLUT10), SLC2A11 (GLUT11) and SLC2A12 (GLUT12) were expressed with an unchanged level, while SLC2A6 (GLUT6) and SLC2A13 (GLUT13/HMIT) were significantly overexpressed after flow (Figure 5(a)). Genes for six monocarboxylate transporters, involved in the transport of lactate, pyruvate, ketone bodies and thyroid hormones, were expressed in BLECs. No change was seen in their expression level after flow, except for SLC16A4 (MCT4) which was significantly elevated (Figure 5(a)). From the large family of amino acid transporters most genes were present at an unchanged level. We found three genes in this group which were upregulated by flow, the sodiumdependent neutral amino acid transporter SLC1A4 (ASCT1), the cationic amino acid 
transporter SLC7A2 (CAT2) and the chloride dependent cystine-glutamate antiporter SLC7A11 (xCT), and only one gene, SLC7A5 (LAT1), which was downregulated (Figure 5(a)). The expression levels of the peptide transporters SLC15A4 (PHT1) and SLC15A3 (PHT2) were not changed by fluid flow (Figure 5(a)). The creatine transporter SLC6A8 (CRT) was significantly upregulated in dynamic condition, while the copper transporter SLC31A2 (CTR2) was not.

Several ion transporters, pumps and channels are expressed at the BBB (Sweeney et al., 2019), that we could confirm in our study (Figure 5(b)). We found no change by flow in the gene expression of the anion exchanger-1 (SLC4A1/AE1), preproteins for voltage-gated $\mathrm{Ca}^{2+}$ channel subunits (CACNA2D1 and CACNB1), the $\mathrm{Na}^{+} / \mathrm{K}^{+}$ATPase (ATP1A1/NKAT), and voltage dependent anion channels (VDAC1-3). Two genes were upregulated after the flow condition, the $\mathrm{HCO}_{3}{ }^{-} \mathrm{Cl}^{-}$exchanger SLC4A2 (AE2) and the $\mathrm{K}^{+}-\mathrm{Cl}^{-}$cotransporter SLC12A4 (KCC1) (Figure 5(b)). Flow condition downregulated the expression of the voltage-gated $\mathrm{K}^{+}$channel $\mathrm{K}_{\mathrm{V}} 1$ subunits (KCNAB1 and KCNAB3) and the $\mathrm{K}_{\mathrm{ir}} 2.1$ inward-rectifier $\mathrm{K}^{+}$channel $(\mathrm{KCNJ} 2)$, and the $\mathrm{Na}^{+}-\mathrm{K}^{+}-\mathrm{Cl}^{-}$cotransporter-1 (SLC12A2/NKCC1).

The penetration of peptides, proteins and lipoproteins through the BBB are controlled by the receptor mediated transporters (Sweeney et al., 2019). We detected the presence of many important BBB receptor genes on the human BBB model (Figure 5(b)). Most of these were not changed by flow, including insulin receptor (INSR), members of the low density lipoprotein receptor family (LDLR, LDLRAD4, LDLRAP1), members of the low density lipoprotein receptor related protein family (LRP1, LRP4, LRP6, LRP8, LRP10, LRP11, LRP12) and transferrin receptor (TFRC). Dynamic condition increased the expression of two receptor genes, LRP3 and LRP5 and decreased the level of LDLRAD3 and very low density lipoprotein receptor (VLDLR). Caveolins regulate endocytosis, transcytosis and signalling in lipid-base domains; the expression level of caveolin-1 (CAV1) gene was decreased by flow, while the expression of CAV2 and clathrin (CLTC) was not changed (Figure 5(b)).

\section{References}

Campos-Bedolla P, Walter FR, Veszelka S, et al. Role of the blood-brain barrier in the nutrition of the central nervous system. Arch Med Res 2014;45(8):610-638.

Daneman R, Zhou L, Agalliu D, et al. The mouse blood-brain barrier transcriptome: a new resource for understanding the development and function of brain endothelial cells. PLoS One 2010; 5(10):e13741.

Sweeney MD, Zhao Z, Montagne A, et al. Blood-Brain Barrier: From Physiology to Disease and Back. Physiol Rev 2019;99(1):21-78

Veszelka S, Tóth A, Walter FR, et al. Comparison of a Rat Primary Cell-Based Blood-Brain Barrier Model With Epithelial and Brain Endothelial Cell Lines: Gene Expression and Drug Transport. Front Mol Neurosci 2018;11:166. 
(a)

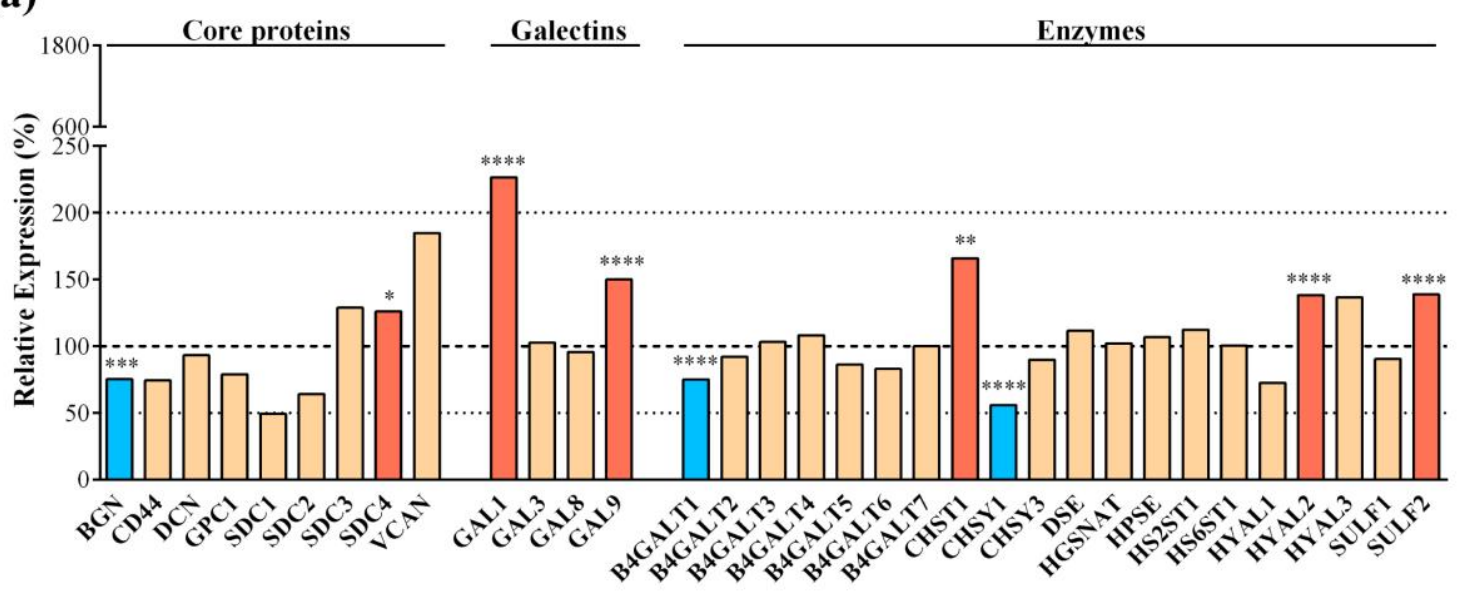

(b)

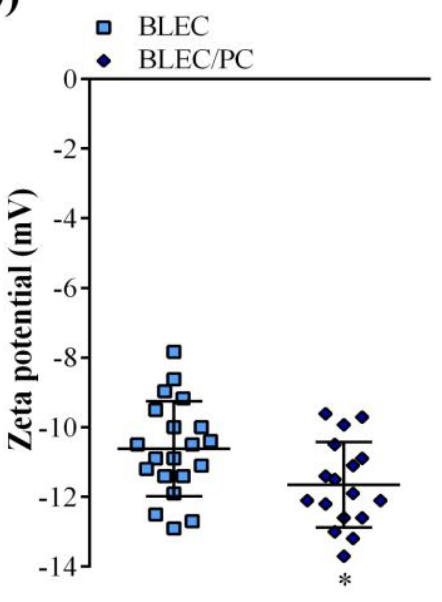

(c)

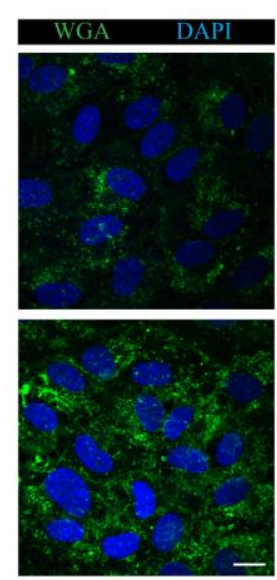

(d)

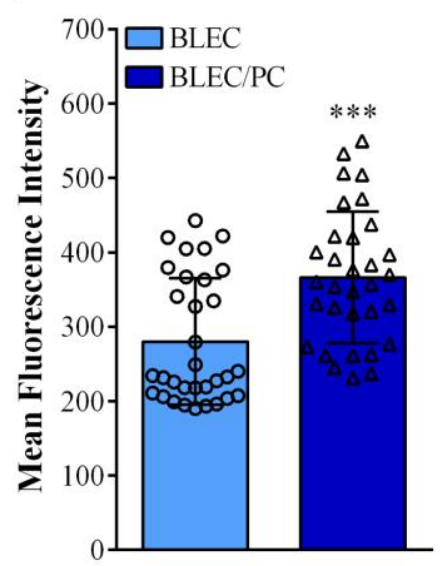

Supplementary Figure S5. Endothelial surface glycocalyx (ESG) of the human BBB model on cell culture inserts. (a) Transcriptomic gene expression profile of ESG-related genes. Expression is shown as the relative expression (\%) of the genes present in human endothelial cells co-cultured with brain pericytes in static condition as compared to solo culture (MACE-seq dataset: GSE144474, Heymans et al., 2020). Testing for differential gene expression was performed using the DESeq2 R/Bioconductor package (Love et al., 2014). Genes with a p-value $<0.05$ and less than $50 \%$ or more than $200 \%$ gene expression levels were considered to be differentially expressed. Red color labels upregulation and statistically significant expression changes, blue color shows downregulation and statistically significant expression change, cream color indicates no change in the gene expression $(* \mathrm{p}<0.05, * * \mathrm{p}<0.01$, ***p<0.001, ****p<0.0001). (b) Zeta potential measured by laser Doppler velocimetry (means $\pm \mathrm{SD}, \mathrm{n}=17-23$, unpaired t-test, ${ }^{*} \mathrm{p}<0.05$ compared to monoculture). (c) and (d): Staining of ESG on brain endothelial cells with fluorescently labeled wheat germ agglutinin (WGA) lectin. WGA binds to the sialic acid residues therefore the fluorescent intensity of the images shows the thickness and density of the glycocalyx components. Scale bar: $20 \mu \mathrm{m}$. Image analysis values are presented as means $\pm S D, n=32$; unpaired t-test, $* * * \mathrm{p}<0.001$ compared to monoculture.

\section{References}

Heymans M, Figueiredo R, Dehouck L, et al. Contribution of brain pericytes in blood-brain barrier formation and maintenance: a transcriptomic study of cocultured human endothelial cells derived from hematopoietic stem cells. Fluids Barriers CNS 2020;17(1):48.

Love MI, Huber W and Anders S. Moderated estimation of fold change and dispersion for RNAseq data with DESeq2. Genome Biol 2014;15(12):550. 